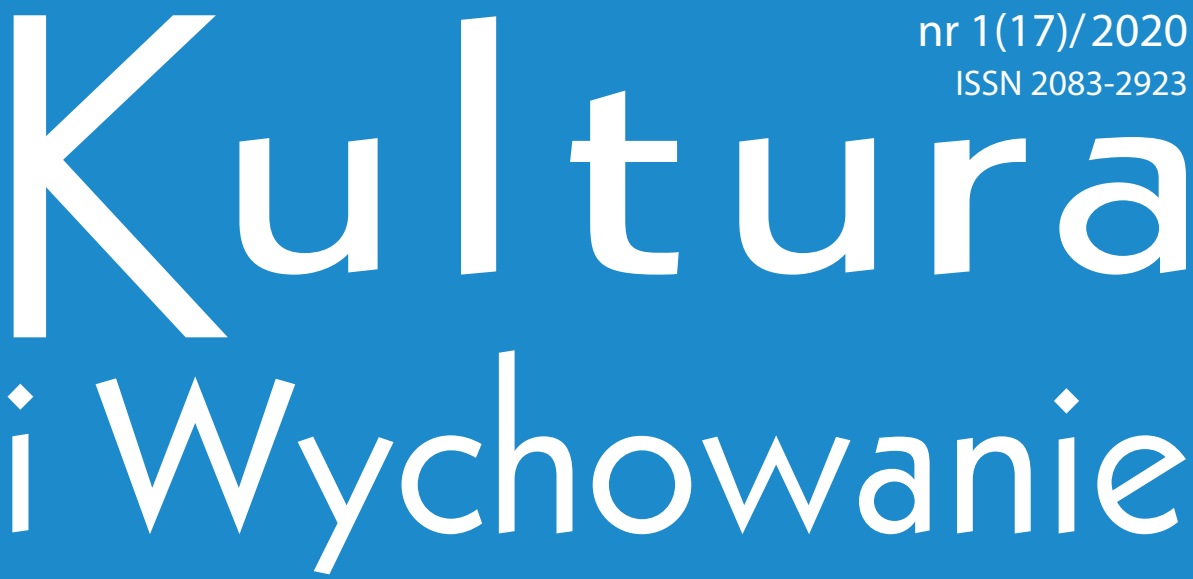

Półrocznik pedagogiczny

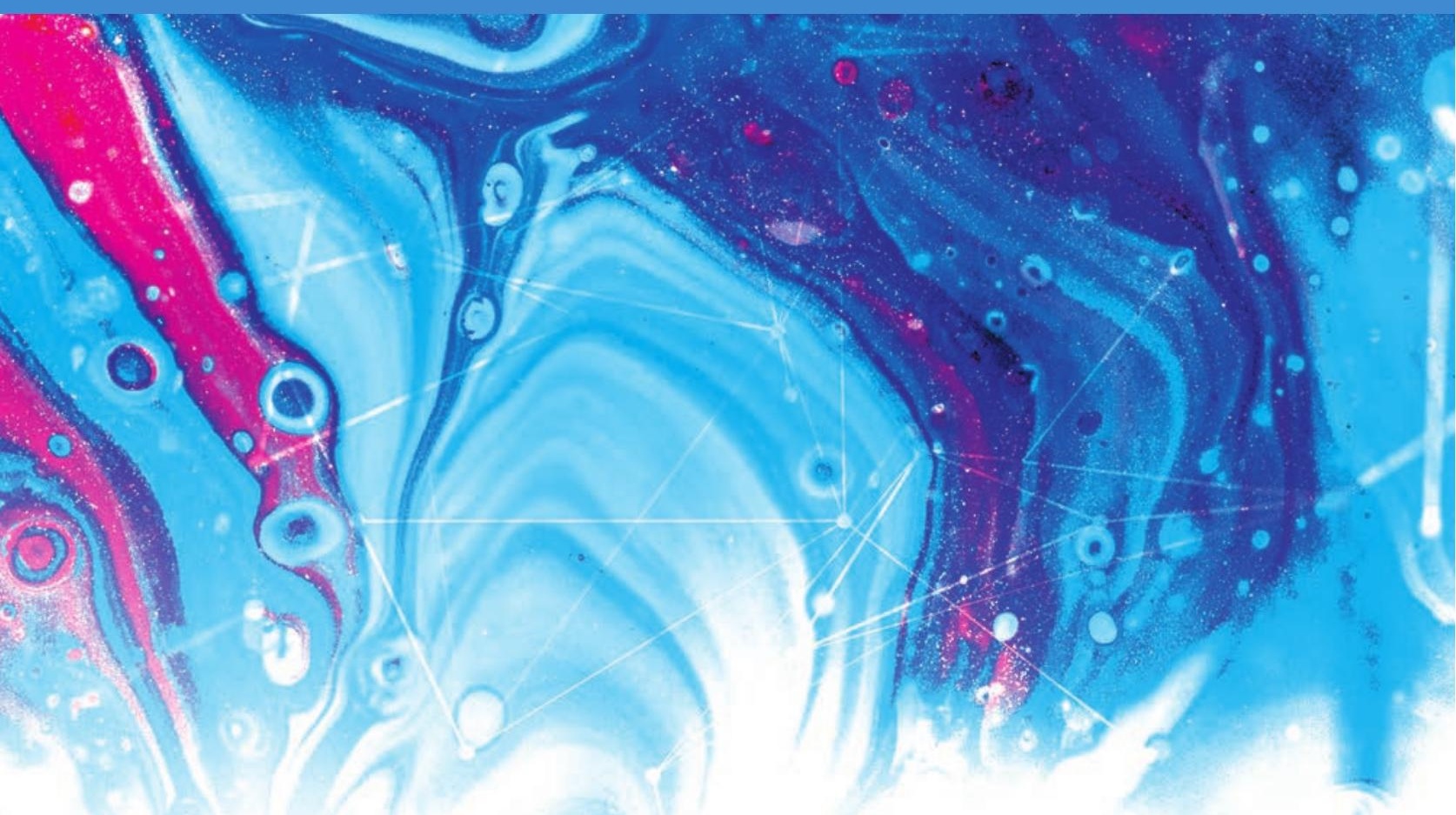

(1) Akademia 

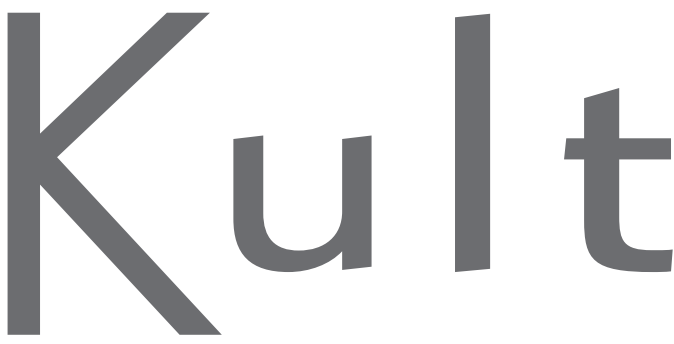

$\mathrm{nr} 1(17) / 2020$

ISSN 2083-2923

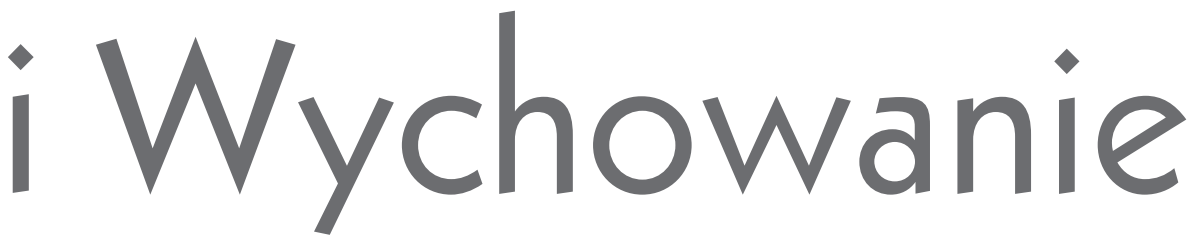

Półrocznik pedagogiczny
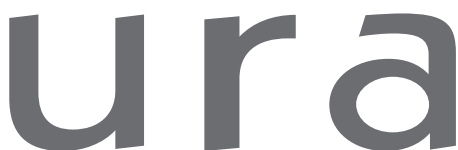
REDAKCJA CZASOPISMA

Redaktor naczelny: dr Krzysztof Kamiński

Z-ca redaktora naczelnego: dr Elżbieta Woźnicka

Sekretarz redakcji: dr Agata Andrzejewska

\section{RADA NAUKOWA}

\section{Przewodnicząca rady naukowej}

dr hab. Zofia Szarota, prof. UW, Uniwersytet Warszawski

\section{Polska rada naukowa}

prof. dr hab. Irena Adamek, Akademia Techniczno-Humanistyczna w Bielsku-Białej prof. dr hab. Stanisław Gałkowski, Akademia Ignatianum w Krakowie dr hab. Rafał Godoń, Uniwersytet Warszawski prof. dr hab. Edyta Gruszczyk-Kolczyńska, Akademia Pedagogiki Specjalnej im. Marii Grzegorzewskiej w Warszawie prof. dr hab. Krzysztof Jakubiak, Uniwersytet Gdański prof. dr hab. Lech Mokrzecki, emerytowany prof. UG, Uniwersytet Gdański prof. dr hab. Bożena Muchacka, Uniwersytet Pedagogiczny im. KEN w Krakowie prof. dr hab. Stanisław Palka, Uniwersytet Jagielloński w Krakowie dr hab. Dariusz Stępkowski, prof. UKSW, Uniwersytet Kardynała Stefana Wyszyńskiego w Warszawie prof. dr hab. Bogdan Szczepankowski, Społeczna Akademia Nauk w Warszawie dr hab. Sławomir Szczyrba, Uniwersytet Kardynała Stefana Wyszyńskiego w Warszawie (WSD w Łodzi)

dr hab. Sławomir Sztobryn, prof. ATH, Akademia Techniczno-Humanistyczna w Bielsku-Białej prof. dr hab. Maria Szyszkowska, Uniwersytet Warszawski, Komitet Prognoz „Polska 2000 Plus” przy Prezydium PAN

\section{Międzynarodowa rada naukowa}

prof. dr hab. Dietrich Benner, Uniwersytet Berliński, Niemcy prof. dr hab. Rudolf Dupkala, Uniwersytet Preszowski w Preszowie, Słowacja prof. dr hab. Blanka Kudláčová, Uniwersytet w Trnavski w Trnavie, Słowacja prof. dr hab. Naděžda Pelcová, Uniwersytet Karola w Pradze, Czechy prof. dr hab. Irina Predborska, Towarzystwo Filozofii Edukacji, Ukraina prof. dr hab. Ałła Wasyluk, Narodowa Akademia Nauk Pedagogicznych Ukrainy, Ukraina 
RECENZENCI „Kultura i Wychowanie” nr 1(17)/2020

dr hab. Jakub Bartoszewski, prof. PWSZ, Państwowa Wyższa Szkoła Zawodowa w Koninie dr Grażyna Cęcelek, Państwowa Uczelnia im. Stefana Batorego

dr Agnieszka Domagała-Kręcioch, Uniwersytet Pedagogiczny im. Komisji Edukacji

Narodowej w Krakowie

prof. dr hab. Wiesław Karolak, Akademia Sztuk Pięknych im. Władysława Strzemińskiego w Łodzi

prof. dr hab. Joanna Madalińska-Michalak, Uniwersytet Warszawski

dr Olga Majchrzak, Akademia Humanistyczno-Ekonomiczna w Łodzi

dr hab. Helena Marzec, prof. AHE, Akademia Humanistyczno-Ekonomiczna w Łodzi

dr dr hab. Danuta Mucha, prof. UJK, Uniwersytet Jana Kochanowskiego

dr Patrycja Ostrogska, Akademia Humanistyczno-Ekonomiczna w Łodzi

dr hab. Dorota Podgórska-Jachnik, prof. UŁ, Uniwersytet Łódzki

dr Wiesław Przybyła, Akademia Humanistyczno-Ekonomiczna w Łodzi

dr hab. Małgorzata Przybysz-Zaremba, prof. PUSB, Państwowa Uczelnia im. Stefana Batorego w Skierniewicach

dr hab. Renata Szczepanik, prof. UŁ, Uniwersytet Łódzki

dr Joanna K. Wawrzyniak, Wyższa Szkoła Bankowa we Wrocławiu

Redakcja czasopisma „Kultura i Wychowanie”

Akademia Humanistyczno-Ekonomiczna w Łodzi

90-212 Łódź, ul. Sterlinga 26

e-mail: kulturaiwychowanie@ahe.lodz.pl

strona www: www.pedagogika.pl

Wydawnictwo Akademii Humanistyczno-Ekonomicznej w Łodzi

90-222 Łódź, ul. Rewolucji 1905 r. nr 64

tel./fax (42) 6315 908; 6315926

wydawnictwo@ahe.lodz.pl

Ten utwór jest dostępny na licencji Creative Commons Uznanie autorstwa-Na tych samych warunkach 4.0 Miedzynarodowe.

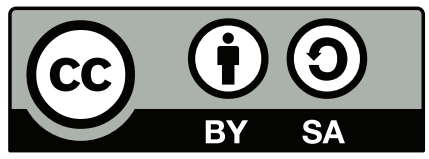


(C) Copyright by Akademia Humanistyczno-Ekonomiczna w Łodzi Łódź 2020

ISSN 2083-2923

Wersją podstawową jest wersja elektroniczna

Projekt graficzny okładki

Joanna Niekraszewicz

Redaktor prowadzący

Iwona Morawska

Redakcja językowa i korekta

Elwira Zapałowska (j. polski)

Ph.D. Michael Fleming (j. angielski)

Opracowanie typograficzne i skład DTP

Monika Poradecka

\section{Wydawnictwo}

Akademii Humanistyczno-Ekonomicznej w Lodzi

90-212 Łódź, ul. Sterlinga 26

tel. 426315908

wydawnictwo@ahe.lodz.pl

www.wydawnictwo.ahe.lodz.pl 


\section{Spis treści}

\section{ARTYKUKY NAUKOWE}

Dariusz Stępkowski, Joanna L. Pękala

Ethics lessons: A school subject in the making..

Agnieszka Gąstoł

Children creating a mess: what underlies this phenomenon

in kindergarten pupils?

Klaudia Smulnik-Barska

Zjawisko „troll parentingu” - modne macierzyństwo,

czy forma krzywdzenia dzieci?

Aneta Jegier

Opieka, wychowanie, edukacja w realiach polskich żłobków

publicznych

Katarzyna Miłek

Wpływ zabaw twórczych na rozwój języka mówionego

u dzieci 5-letnich

Natalia Bednarska

Budowanie strategii szkoły wobec prac domowych uczniów

Tobiasz Janikowski

Indywidualizacja i ,polifonizacja” nauczania języka obcego

w szkole muzycznej

Anna Mikler-Chwastek

Trudności w organizacji współpracy między nauczycielami

a rodzicami uczniów - sprawozdanie z badań .

Grażyna Cęcelek

Specyfika przywództwa edukacyjnego w szkole oraz jej otoczeniu. 
Agnieszka Krawczyk

Skrivnosti Nika Grafenauera jako ujawnianie tajemnic.

\section{SPRAWOZDANIA I RECENZJE}

Natalia Piórczyńska

Recenzja książki Lustereczko, powiedz przecie Simona Blackburna,

Wydawnictwo Uniwersytetu Łódzkiego, Łódź 2018, 350 stron

Jasmina Al-Douri

Recenzja książki Anny Konarzewskiej Być (nie)zwykłym wychowawcą.

Scenariusze lekcji wychowawczych dla uczniów klas starszych szkoły

podstawowej oraz szkót ponadpodstawowych, Warszawska Firma

Wydawnicza, Warszawa 2019, 217 stron

\section{STUDENCI PISZA}

Katarzyna Ewa Kuchnicka

Metoda sióstr Agazzi w wychowaniu przedszkolnym 


\section{Contents}

\section{ACADEMIC ARTICLES}

Dariusz Stępkowski, Joanna L. Pękala

Ethics lessons: A school subject in the making...

Agnieszka Gąstoł

Children creating a mess: what underlies this phenomenon

in kindergarten pupils?

Klaudia Smulnik-Barska

The phenomenon of "troll parenting" - fashionable motherhood or a form of child abuse?

Aneta Jegier

Care, upbringing, education in the reality of Polish public nurseries....

Katarzyna Miłek

The influence of creative play on the development of spoken

language in 5-year-old children

Natalia Bednarska

Building a school strategy for students' homework

Tobiasz Janikowski

Individualisation and "polyphonization” of foreign language

teaching in music schools

Anna Mikler-Chwastek

Participation and cooperation of teachers with pupils' parents

Grażyna Cęcelek

The specificity of educational leadership at school and its environment 
Agnieszka Krawczyk

Skrivnosti by Niko Grafenauer as the revealing of secrets

\section{REPORTS AND REVIEWS}

Natalia Piórczyńska

Review of the book Mirror, Tell After All [Mirror, Mirror: The Uses and Abuses of Self-Love] by Simon Blackburn,

University of Lodz Publishing House, Lodz 2018

Jasmina Al-Douri

Review of the book by Anna Konarzewska To be a (not) ordinary

educator. Scenarios of parenting lessons for elementary school

and post-primary school students, Warsaw 2019

\section{STUDENTS WRITE}

Katarzyna Ewa Kuchnicka

The Agazzi Sisters method in preschool education 
Dariusz Stępkowski* (iD http://orcid.org/0000-0002-6855-1517

Cardinal Stefan Wyszyński University in Warsaw

Joanna L. Pękala** (iD http://orcid.org/0000-0003-4554-1962

University of Warsaw

https://doi.org/10.25312/2083-2923.17/2020_01dsjp

\title{
Ethics lessons: A school subject in the making
}

\begin{abstract}
This article discusses the teaching of ethics in the educational system in Poland as a separate subject. The first part describes the historical process that brought ethics into the school curriculum. The second part provides knowledge about the legal status of ethics instruction and the prevalence of participation in ethical education. In the third part, the authors analyse the guidelines on teaching ethics for primary and secondary schools contained in the Core curriculum of general education.
\end{abstract}

Keywords: ethics, ethics teaching, education, educational system

\footnotetext{
* Dariusz Stępkowski - Ph.D., is an associate professor at the Faculty of Education of the Cardinal Stefan Wyszyński University in Warsaw, Poland. His main publications: Herbart znany i nieznany (co-editor, 2006), Pedagogika ogólna i religia (2010), Wychowanie i kształcenie $w$ systemach politycznych (co-editor, 2012), Bildung und Erziehung in politischen Systemen (co-editor, 2012), Religion long forgotten (co-editor, 2014), Bildung - Moral - Demokratie (co-author, 2015), Kształcenie moralność - demokracja (co-author, 2018), Istota, sens i uwarunkowania (wy)kształcenia (co-author, 2019). His research interests include the philosophy of education, moral education, high school teaching theory.

** Joanna L. Pękala - Ph.D. in social sciences in the field of education, adjunct at the Faculty of Education of the University of Warsaw. She is a longtime teacher of early school and nursery school education. The author's research interests include teacher training, ethical issues related to teachers' work, and teacher education. Selected publications: Teachers' ethos today: expectations and opinions (2018), Etos nauczycieli - mit czy rzeczywistość? (2017), Kompetencje etyczne nauczyciela (2017), Nauczyciele a rodzice - oczekiwania i motywacje (2015), Nauczyciel dziś - pedagog czy edukator (2014), Dylematy wspótczesnego polskiego nauczyciela (2012).
} 


\section{Introduction}

One of the changes that occurred in the school curriculum after the collapse of the communist system in Poland in 1989 was the emergence of ethics as a subject. It is true that schools offered moral education, but it only became a "normal" school subject in the last two centuries. ${ }^{1}$ The teaching of moral ethics in the Polish educational system was linked to two processes. The first was the political transformation and the second was secularisation. Both these processes still leave a significant mark on the discussion on the objectives of school ethical instruction in Poland. ${ }^{2}$

The analyses presented below relate to teaching ethics in the educational system in Poland after the political breakthrough in 1989. The first part describes the historical process that brought ethics into the school curriculum as a separate subject. The second part provides knowledge about the legal status of ethics instruction and the prevalence of children's and youth's participation at ethics classes. In the third part, the authors analyse the guidelines on teaching ethics for primary and secondary schools contained in the Core curriculum of general education.

\section{History of ethics as a school subject}

In Poland, ethics lessons were introduced to public schools in 1990 due to the restoration of religious education. The latter was removed from public education in 1961 during the first reform of the school system after World War II, which was carried out by the "people's authorities". ${ }^{3}$ Former realities could not be recreated until after the socio-political-cultural breakthrough in 1989. However, this was not a return to the status quo almost three decades ago. Both historical moments are distinguished by the appearance of ethics in the school curriculum ${ }^{4}$. 1 September 1990 was the date not only of the return of religious education to the Polish public education system, but also the beginning of teaching ethics as a separate subject.

${ }^{1}$ D. Stępkowski, School Moral Education: Does Scholastic Ethical Instruction Need Its Own 'Morality'?, [in:] B. Kudláčová, A. Rajský (eds.), Education and "Pädagogik" - Philosophical and Historical Reflection, Berlin 2019, pp. 147-155; D. Benner, R. Nikolova, Stan umiędzynarodowienia badania ETiK i jego koncepcja teoretyczno-empiryczna, "Forum Pedagogiczne", 2019, 2 (1), pp. 22-25.

${ }_{2}^{2}$ J.M. Madalińska-Michalak, A.J. Jeżowski, Etyka i religia jako przedmioty nauczania: konkurencyjność czy komplementarność?, "Forum Oświatowe”, 2018, 30 (2), pp. 219-241. Retrieved March 1, 2020, from: http://forumoswiatowe.pl/index.php/czasopismo/article/view/655/416.

3 T. Hejnicka-Bezwińska, Praktyka edukacyjna w warunkach zmiany kulturowej (w poszukiwaniu logiki zmian), Warszawa 2015, pp. 292-296.

${ }^{4}$ In the past, representatives of the socialist theory of education promoted the project of instilling secular materialistic morality for children and youth. This was to be done not in the form of school lessons, but in moral education, which would cover all spheres of individual and social life. Cf. B. Suchodolski, O program świeckiego wychowania moralnego, Warszawa 1961; H. Muszyński, Wychowanie moralne w zespole, Warszawa 1974. 
The conditions and manner of organizing ethics instruction were set out in the regulation of the Ministry of National Education (hereafter MEN) in 1992, which still applies with only minor amendments. ${ }^{5}$ Ethical education is presented as a substitute for religious education. This means that parents who do not wish to raise their children religiously at school, or pupils themselves when they reach the age of majority, can report to the school authorities the desire to receive ethics instruction. The headmaster is responsible for organizing these classes on the spot, i.e. in a given school if the number of pupils is at least seven, or in inter-school groups if there are less than seven pupils but not less than three.

The actual practice of organizing ethics classes in the first two decades was poor and did adhere to regulations. Leading school authorities responded sluggishly to parents and pupils demands for ethics classes. This led to a case at the European Court of Human Rights (ECHR) in Strasbourg - Grzelak v. Poland. ${ }^{6}$ The trial ended in 2010. The subject of the trial was the complaint of Czesław and Urszula Grzelak, who demanded from the Polish State that they would realistically guarantee their son Mateusz the opportunity to attend ethics classes after they had discharged him from religious education at school. The headmasters of several public schools which their son attended refused to organize such classes only for him, on the grounds that there were not enough applicants - at least three pupils were required.

The ECHR judges found that the lack of access to ethical education in Polish public schools is a violation of the freedom of religion and the prohibition of discrimination. On this basis, they obliged the Government of Poland to introduce changes that will effectively contribute to respecting the indicated prerogatives. In this context, it is worth noting that the ECHR's decision on teaching ethics in Polish schools referred to anti-discrimination standards. The consequences this will be discussed below.

Corrective actions were implemented after the ECHR's verdict. In connection with this, the MEN issued an amendment to the regulation of 1992 in $2014 .^{7}$ In principle, the changes concerned two matters: firstly, the abolition of the criterion making the formation of an inter-school group dependent on at least three pupils enrolled and, secondly, clarifying the form of making a wish regarding participation in religion or ethics classes - instead of the statement expressed "in simplest form", "a written statement" has been introduced, while maintaining the possibility of changing it at any time.

${ }^{5}$ Rozporzadzenie Ministra Edukacji Narodowej z dnia 14 kwietnia 1992 r. w sprawie warunków i sposobu organizowania nauki religii w szkołach publicznych, Dz.U. z 1992 r. Nr 36, poz. 155.

${ }^{6}$ Sprawa Grzelak przeciwko Polsce (skarga $n r$ 7710/02). Retrieved March 1, 2020, from: http:// trybunal.gov.pl/polskie-akcenty-w-orzecznictwie-miedzynarodowym/rada-europy-europejski-trybunal-praw-czlowieka/w-sprawach-polskich/art/8251-sprawa-grzelak-przeciwko-polsce-skarganr-7710-02-wyrok-z-15-czerwca-2010-r/.

${ }^{7}$ Rozporzadzenie Ministra Edukacji Narodowej z dnia 25 marca 2014 r. zmieniające rozporządzenie w sprawie warunków i sposobu organizowania nauki religii w publicznych przedszkolach i szkołach, Dz.U. z 2014 r., poz. 478. 
One of the most important consequences of the translocation of ethical education in Poland into the sphere of equality (anti-discrimination) policy initiated by the ECHR's judgment was the inclusion of this issue by the Ombudsman in the scope of his competence. Adam Bodnar, who was in office at the time, commissioned a study on the availability of minority religion classes and ethics classes in Poland. In the published report, the Ombudsman formulated a number of postulates regarding ethical education. He demanded, among others:

- keeping statistics by the MEN on the basis of which it would be possible to estimate actual access to ethics classes in Polish schools and monitor its dynamics;

- conducting a campaign directed at parents to inform them of their children's right to ethics classes at school;

- imposing the obligation to organize ethics instruction by law, and not only by regulation of the $\mathrm{MEN}$;

- formal commitment of headmasters to inform all parents and pupils at the beginning of the school year about the possibilities and principles of organizing ethical education;

- introducing ethical education in nursery schools on the same principles as religious education;

- recognition of all barriers to access to ethics instruction as a manifestation of discrimination. ${ }^{8}$

The above postulates were repeated by Bodnar in his communications with the MEN. He called for compliance with the principles of equality in the field of ethical education in public schools. ${ }^{9}$ The replies of the MEN have consistently emphasized that the existing provisions of educational law sufficiently counteract discrimination in schools regarding ethics instruction. In this way, opposition to principles from outside educational law was opposed.

The intentions behind the aspirations to reclassify ethics education to the competence scope of equality (anti-discrimination) policy are revealed by the statement contained in the Ombudsman report. It is true that it primarily refers to religious education, but by analogy it also concerns ethical education. "Discrimination on the grounds of religion in the field of education should be considered [...] prohibited under the provisions of the Constitution and international law in force in Poland, however, victims of discrimination cannot benefit from the measures provided for in the Act of December 3, 2010 on the implementation of certain European Union rules on

\footnotetext{
${ }^{8}$ A. Bodnar, Dostępność lekcji religii wyznań mniejszościowych i lekcji etyki w ramach systemu edukacji szkolnej. Analiza i zalecenia, "Biuletyn Rzecznika Praw Obywatelskich", 2015, 6, pp. 51-55. Retrieved March 1, 2020, from: https://www.rpo.gov.pl/sites/default/files/BIULETYN RZECZNIKA PRAW OBYWATELSKICH 2015 nr 6.pdf.

9 A. Bodnar, RPO w sprawie szkół, uczniów, rodziców i nauczycieli. Przykłady spraw z kadencji 2015-2019, 2019. Retrieved March 1, 2020, from: https://www.rpo.gov.pl/sites/default/files/RPO w sprawie szkół.pdf.
} 
equal treatment and seeking compensation on this basis." ${ }^{10}$ Reclassifying the problem of ethics and religion instruction in schools would provide tools to bring financial claims before the courts for "moral harm".

In view of the above, it is not surprising that the topic of ethical education in Polish schools is characterized by a strong ideological tinge. It certainly does not positively influence the essential discussion on moral and ethical education in the contemporary school system. ${ }^{11}$

\section{Dissemination of ethical education}

In the previous section, the legal status and organization of ethics instruction in public schools in Poland have been explained in part. Further elaboration is provided below. The authors also present available statistical data on the participation of children and young people in ethical education.

Pursuant to the applicable provisions of Polish educational law, ethical education - like religious education - is not compulsory, but optional. The pupils have the right to participate in classes in religion, ethics, both subjects, and may not choose any of them. Participation is decided by parents or senior pupils by submitting a written statement. After submitting the statement, participation becomes mandatory. Headmasters have the responsibility to organize ethics teaching for each pupil, even if there is only one. If, in a given school, some pupils express their wish to attend classes in both religion and ethics, the school authority is obliged to enable them to participate in both subjects, placing them without collision in the school timetable. If pupils do not attend religion or ethics classes at school, they should be provided with care activities for the duration of these classes.

In Poland, the practice is widespread, whereby pupils dropping out of religion classes do not report willingness to learn ethics and are directed to a common room or school library, where they spend their time more or less idle.

Ethics instruction can be held at all types of public schools. However, there is no provision for teaching ethics in nursery, although religious education can be provided there at the parents' request. Weekly ethics teaching hours are set by the school head. Usually it is 45-minute lesson a week.

An ethics teacher can be a person who has achieved the level of education required for a given type of school, finishing accordingly: (1) higher education (bachelor's or master's) degree in philosophy or ethics and a pedagogical qualification course or (2) higher education (bachelor's or master's) degree in a field of study whose pro-

\footnotetext{
10 A. Bodnar, Dostępność..., op.cit., p. 17.

11 D. Stępkowski, Kształcenie religijne w publicznym interesie. Perspektywa pedagogiki ogólnej, "Przegląd Pedagogiczny", 2018, 2, pp. 103-119; J.M. Madalińska-Michalak, A.J. Jeżowski, Etyka i religia..., op.cit., pp. 219-241.
} 
gram covered the content of the ethics or philosophy, e.g. in humanities, including theology, and pedagogical qualification course, or (3) higher education (bachelor's or master's) degree in a different field than the ones mentioned above, and also completed post-graduate studies in philosophy or ethics and a pedagogical qualification course. ${ }^{12}$

At the first educational stage, i.e. in grades 1-3 of primary school, an early school education teacher can also conduct ethics instruction.

The ethics grade is placed on the certificate and is included in the average. However, it does not affect the promotion to the next school level.

Objectives, teaching content, recommended conditions and method of conducting classes in ethical education are specified in the national Core curriculum of general education, the latest amendment of which entered into force in 2017. They will be discussed in more detail in the next section.

In accordance with the requirements of educational law, an ethics teacher presents the school headmaster with his/her curriculum. The headmaster, after consulting the teaching council, approves the program proposed by the teacher for use and enters it into the school's set of curricula. When preparing his/her curriculum, a teacher can use programs that have been recommended by the MEN as suitable for school use. It should be emphasized that these programs are not obligatory.

Ethics textbooks require approval from the MEN. Most textbooks were created for teaching ethics in upper secondary school (liceum ogólnokształcace). Most of them are certified by the MEN.

The above-mentioned Ombudsman report states that: "The statistical data collected by the MEN do not contain information about which denominations of religion are instructed at school, or how many pupils attend minority religion classes or ethics classes. Currently, data are aggregated in one general position: teaching ethics and religion at school." 13 This undoubtedly makes it difficult to estimate the prevalence of participation of children and youth in ethical education in public schools. Citing data obtained from the MEN, the same report presents data for the 2014/2015 school year. They will be used below to outline the prevalence of ethics instruction in Poland.

The table below summarizes the number of nursery schools and public schools where ethical education was held and in which there were no such classes, with the total number of educational institutions of a given type in the 2014/2015 school year.

12 Rozporządzenie Ministra Edukacji Narodowej z dnia 1 sierpnia 2017 r. w sprawie szczegółowych kwalifikacji wymaganych od nauczycieli, Dz.U. z 2017 r., poz. 1575.

13 A. Bodnar, Dostępność..., op.cit., p. 51. 
Table 1. Teaching ethics in nursery schools and public schools in the $2014 / 2015$ school year

\begin{tabular}{|l|c|c|c|}
\hline \multicolumn{1}{|c|}{$\begin{array}{c}\text { Type of educational } \\
\text { institution }\end{array}$} & $\begin{array}{c}\text { Number of educational } \\
\text { institutions with ethics } \\
\text { education }\end{array}$ & $\begin{array}{c}\text { Number of educational } \\
\text { establishments without } \\
\text { ethics education }\end{array}$ & $\begin{array}{c}\text { Total number of } \\
\text { educational institutions }\end{array}$ \\
\hline Nursery school & $27(0.85 \%)$ & $3,133(99.15 \%)$ & 3,160 \\
\hline primary school & $1,119(9.1 \%)$ & $11,231(90.9 \%)$ & 12,350 \\
\hline junior high school & $815(12.4 \%)$ & $5,758(87.6 \%)$ & 6,573 \\
\hline basic vocational school & $89(5.7 \%)$ & $1,468(94.3 \%)$ & 1,557 \\
\hline upper secondary school & $448(24.4 \%)$ & $1,385(75.6 \%)$ & 25,473 \\
\hline total (100\%) & $2,498(9.77 \%)$ & $22,975(90.23 \%)$ & \\
\hline
\end{tabular}

Source: Based on A. Bodnar, Dostępność..., op.cit., p. 34.

In the 2014/2015 school year, there were a total of 25,473 nursery school and public schools of various levels in Poland (primary, junior high and secondary schools: vocational schools and general secondary schools). Ethics instruction were conducted in every tenth of them, with the exception of nursery, the smallest percentage was recorded in basic vocational schools (5.7\%), and the largest in upper secondary schools (24.4\%).

The next chart presents data illustrating the dynamics of growth that has occurred in relation to the dissemination of ethical education in public schools over the past two decades. The function of the measuring tool is played by conversion of the amount of public schools with ethics education and full-time ethics teachers' jobs. The data was obtained from the research study on teaching ethics in the Polish educational system ${ }^{14}$ and the website "Etyka w szkole". ${ }^{15}$

${ }^{14}$ J.M. Madalińska-Michalak, A.J. Jeżowski, Sz. Więsław, Etyka w systemie edukacji w Polsce. Warszawa 2017, pp. 40-41.

${ }^{15}$ https://www.etykawszkole.pl/. 


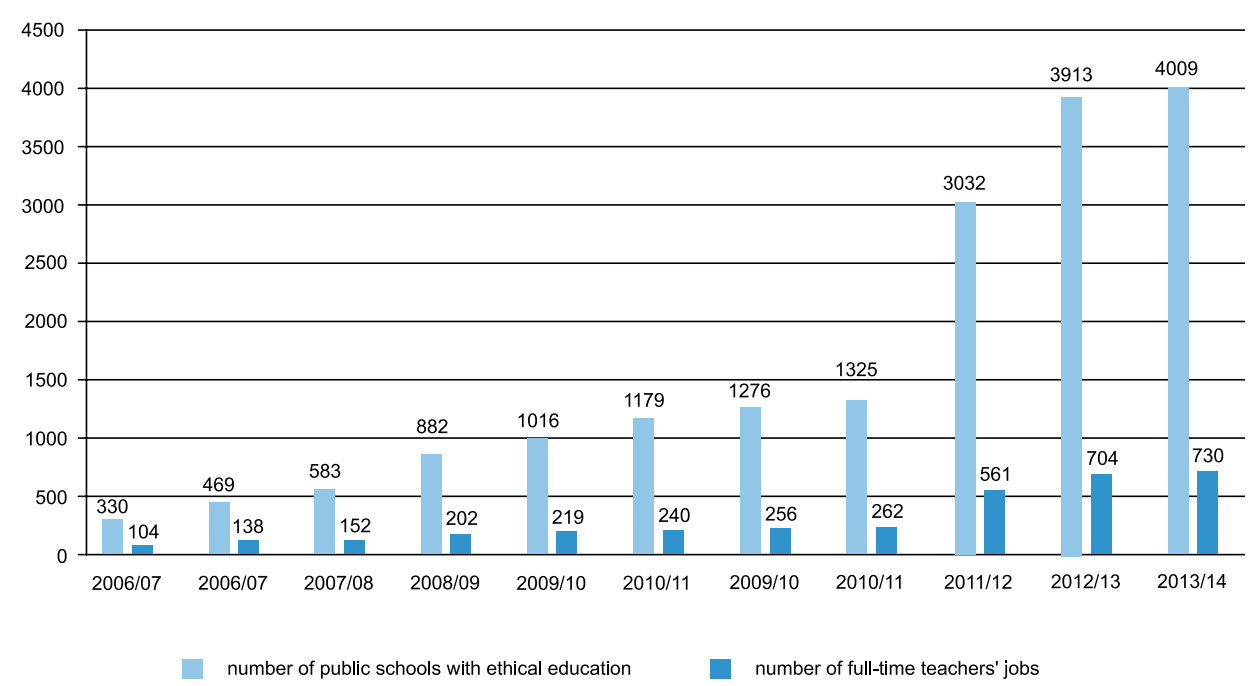

Chart 1. Juxtaposition of the number of public schools with ethical education and the number of full-time ethics teachers' jobs Source: Own elaboration.

The chart above shows a rapid increase in the number of public schools with ethics instruction occurred in the 2014/2015 school year. There were $128.8 \%$ more such a school than a year previous. The situation was similar with the number of ethics teachers' jobs, where they increased by $114.1 \%$ compared to the previous year. When comparing the numbers of both measures with the 2006/2007 school year, it turns out that the increase in public schools with ethical education was nine-fold, while the number of full-time ethics teachers' jobs increased fivefold. It is true that the upward trend in both ranges continued even in the 2015/2016 school year, but the resulting increases were not so spectacular. The number of public schools with ethics instruction and the full-time ethics teachers' jobs increased by $29 \%$ and $25.5 \%$ respectively compared to the previous year. This process slowed down in 2016/2017 school year, when 96 public schools with ethics classes arrived, which means an increase of only $2.5 \%$ compared to the previous year, and 26 full-time ethics teachers' jobs, i.e. $3.7 \%$ more than a year earlier.

Of course, based on the data presented so far, it is difficult to make reasonable assumptions about the future of ethical education. As it was written in the Ombudsman report: "Ethics is slowly ceasing to be treated as [...] opposition to religion." ${ }^{16}$ On the other hand, the crisis of religious education is clearly outlined in public education. The phenomenon is indicated quite clearly by the results of research conducted since 1991 by the Centrum Badania Opinii Społecznej (Public Opinion Research Center, hereafter CBOS) on the subject of youth religiosity, i.e. high school pupils. The chart

\footnotetext{
${ }^{16}$ A. Bodnar, Dostępnośćc.., op.cit., p. 6.
} 
below presents the percentage proportions of pupils participating in and not participating in religious education at school in subsequent editions of the study.

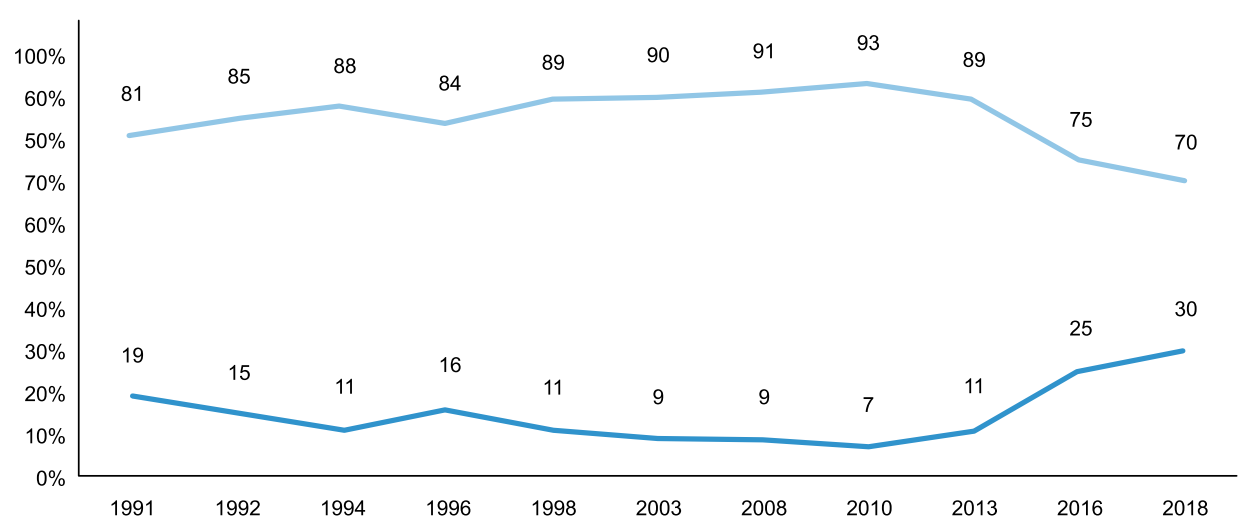

Chart 2. Participation of upper secondary school pupils in religious education at school Source: CBOS, Młodzież 2018, eds. by M. Grabowska, M. Gwiazda. Warszawa 2019, p. 16.

A systematic decrease in the percentage of pupils participating in religious education at school has been observed since 2010. In a sense, this is a reversal of the trend recorded in the earlier period, when these percentages increased, reaching a maximum value of $93 \%$ in 2010. Starting from the measurement carried out in 2013, this indicator is drastically falling down. In 2018, only $70 \%$ of pupils declared participation in religious education at school, i.e. the least in the history of research conducted by CBOS.

Of course, the decline of religious education in public schools cannot be interpreted as an announcement of a further increase in the demand for ethical education. To justify this, it is enough to recall the practice indicated above, according to which pupils having a choice of religion classes or ethics classes do not choose any of the possible options. This state of affairs must raise general concern - both among those preferring the teaching of religion at school and those preferring the teaching of ethics. Nobody should imagine winning in this situation. And the biggest loser will definitely be the young generation.

\section{Curriculum for ethical instruction}

As indicated above, the objectives, content, effects (achievements), recommended conditions and method of implementing ethics as a school subject are included in the Core curriculum of general education. This is the document of the MEN which contains directives for public schools of all levels and types regarding general education and subjects falling within its scope. The ministerial guidelines on teaching ethics in primary and secondary school will be analysed below. 


\subsection{Primary school}

Education in primary school in Poland lasts 8 years and is divided into two stages: the first includes classes 1-3, the second classes 4-8. In the first stage, teaching takes the form of integrated education. This means that there is no division into subjects yet, and the contents falling within the scope of early school education are divided into thematic areas, e.g. Polish language, mathematics, social education, nature education. In total, 13 such areas have been identified in the core curriculum. Ethical education is one of them.

The second educational stage characterizes subject teaching. The list contained in the core curriculum includes 21 subjects, including ethical education.

Based on the Regulation of the MEN of February 14, 2017, in primary school, there are 13 goals to achieve. From the perspective of moral and ethical education, it is worth paying attention to the following:

1) introducing pupils to the world of values, including cooperation, solidari-

ty, altruism, patriotism and respect for tradition, showing best practices and building social relations conducive to the safe development of the pupil (family, friends);

2) strengthening the sense of individual, cultural, national, regional and ethnic identity;

3) forming pupils' sense of dignity and respect for the dignity of others; [...]

5) developing the skills of critical and logical thinking, reasoning and argumentation; [...]

8) equipping pupils with such information and shaping such skills that allow them to understand the world in a more mature and orderly way; [...]

11) shaping an open attitude towards the world and other people, activity in social life and responsibility for the community; [...]

13) orienting the pupil towards values. ${ }^{17}$

Due to the division of primary school education into two stages, program assumptions related to ethical education will be discussed separately for each of them.

The overall goal of early school education is to support the integral development of a child in all areas (they will be discussed below). It is worth pointing to one of the recommendations addressed to early school education. The organization of classes is to enable pupils to "learn about social values and norms which source is family, local and regional community, nation, and to develop behaviours resulting from these values and which the child can understand at a given stage of development." 18

${ }^{17}$ Rozporzadzenie Ministra Edukacji Narodowej z dnia 14 lutego 2017 r. w sprawie podstawy programowej wychowania przedszkolnego oraz podstawy programowej ksztatcenia ogólnego dla szkoty podstawowej, w tym dla uczniów z niepetnosprawnościa intelektualna $w$ stopniu umiarkowanym lub znacznym, kształcenia ogólnego dla branżowej szkoły I stopnia, kształcenia ogólnego dla szkoły specjalnej przysposabiajacej do pracy oraz kształcenia ogólnego dla szkoły policealnej, Dz.U. z 2017 r., poz. 356, p. 11.

${ }^{18}$ Ibidem, p. 17. 
In the document analysed, all attention is directed to the effects (achievements) that the pupil should display thanks to ethical education. These effects (achievements) have been described in the curriculum up to two times. First, in assigning to four areas of pupil development, namely: physical, emotional, social and cognitive. In the formulations referring to each of these areas, one can see effects (achievements) which are influenced by teaching ethics, e.g. "the ability to respect the rules of games, team play and rules of moving in public places" (physical development) or "awareness of values recognized by the home, school, local and national environment; the need for social activity based on these values" (social development).

The second, much more detailed description of the effects (achievements) of ethical education as one of the thematic areas is included in the core curriculum in the part titled "Teaching contents". Contrary to expectations, there are no recommendations as to the topics or material suggestions that can be used during classes with pupils, but a list of expected effects (achievements). It was divided into two parts: "Achievements in understanding basic principles and concepts of ethics" and "Achievements in the application of known principles". ${ }^{19}$ In the first part of the list with the help of the so-called operational verbs have been described the understanding of the following ethical concepts: "dignity", "freedom", "good", "choice”, "responsibility", "happiness", "community", "respect", and moral principles: determining what is good and what is wrong, distinguishing happiness from temporary pleasure and establishing by the community of people their rules and norms.

The second part of the discussed list of effects (achievements) of ethical education can be considered a practical application of the principles presented in the first part. Also here, operational terminology is used, i.e. verbs such as "A pupil respects...", "A pupil expresses...", "A pupil takes into account..., "A pupil enters into relationships...", "A pupil names..., "A pupil mimics..., "A pupil observes..."

As already mentioned above, ethical education at the second stage of primary school, i.e. in the classes $4-8$, takes the form of regular subject teaching. Therefore, the classes are conducted in 45-minute units, whose participants are usually pupils from different classes and even schools.

The goals of teaching ethics are grouped in the core curriculum in four areas, namely: (1) axiological sensitivity and reflectivity, (2) moral reasoning, (3) moral attitudes and (4) self-education. Regarding the criterion of this division, it is worth noting that: "Ethics as a school subject taught in primary school is to achieve primarily practical and educational goals." ${ }^{20}$ On this basis, it can be assumed that it is less a matter of theoretical inquiry, but rather practical skills resulting from reflection on moral and ethical problems. Confirmation of this assumption are the objectives contained in these four areas. For example, the last one (self-education) mentions

\footnotetext{
19 Ibidem, pp. 52-53.

20 Ibidem, p. 207.
} 
the following: "1. Developing the skills of independent search for information, their valuation and reliable and responsible use of knowledge. 2. Recognizing and solving moral problems. 3. Identifying and eliminating factors limiting agency. 4. Developing moral self-awareness." ${ }^{21}$

It is noteworthy that the authors of the core curriculum are fully aware that: "The expression of the sphere of moral autonomy of the pupil is expanding by his/her gradual internalisation of moral values and norms and a deepening understanding of himself as a moral subject," however, "teaching ethics can only assist the pupil in actually accomplishing this key task; its effective implementation requires [...] the decision of the pupil him/herself, complementarity of educational interactions and many years of the pupil's work on him/herself." 22

Unlike most subjects, the content of ethical education was not assigned in the core curriculum to separate degrees of school learning and teaching, but was grouped into eight thematic sections. It seems that the reason for this decision is the fact that ethics classes usually take place in inter-departmental and inter-school groups, which practically prevents the teacher from working with a homogeneous pupil group. In other words, pupils with diverse knowledge and level of moral development participate in these classes. Consequently, it requires the teacher to skilfully select the content of ethical education.

At the core of these eight thematic sections, to which the teaching content has been sorted, lies the logic characteristic of school education. It is characterized by a gradual transition from theoretical knowledge through skills to practical application.

The first section indicates key issues in general ethics that relate to the cognitive, emotional and behavioural aspect of morality. The emphasis was on educating "linguistic thinking". ${ }^{33}$ Thus, the creators of the core curriculum define the focus of teaching ethics on concepts and activities that enable dealing with moral phenomena. These are the following groups of concepts and activities:

1) the cognitive aspect: "decision, deed, agency, conflict, problem, subject of the action (author, perpetrator), recipient of the action, intention of action, motive of action, contentiousness, effect (consequence), circumstances of action" ${ }^{24}$; "Good, evil, value, criterion, principle (norm, rule), attitude, virtue, defect, duty, sanction, conscience, model, authority, responsibility, natural law, constitutional law, dignity, human rights, human nature, truth, happiness"25; "prescribed, prohibited, permitted, optional (supererogation)"26;

\footnotetext{
${ }^{21}$ Ibidem, p. 202.

${ }^{22}$ Ibidem, p. 207.

${ }^{23}$ Ibidem, p. 208.

${ }^{24}$ Ibidem, p. 202.

${ }^{25}$ Ibidem, p. 203.

${ }^{26}$ Ibidem.
} 
2) the emotional aspect: "joy, sadness, fear, disgust, surprise, anger, acceptance, pride, love, hatred, pleasure, annoyance, happiness, shame, guilt, jealousy"27;

3) behavioural aspect: naming, describing, explaining, discussing, distinguishing and analysing.

Sections from two to six contain directives as to the objectives (achievements) that the pupil should achieve after analysing the possible relationships in which (s)he experiences the world in and around him/herself and can act in it. The titles of these sections are "Man to other people", "Man to himself", "Man and the world of human products", "Man to nature", and finally "Man to God (Sacrum)".

The contents of teaching in the seventh and eighth sections are optional. It is expected that thanks to the seventh section, the pupil will acquire the ability to systematically consider moral problems. This skill consists in particular in (1) identifying and classifying a given problem, (2) x-raying it through the prism of one's own experience, (3) precisely formulating a moral problem in the form of a question, (4) analysing it by using the concepts of ethical discourse, and finally (5) discussing with other pupils.

The eighth section includes selected representatives of the history of philosophical ethics and their theories, namely Socrates, Aristotle, Kant, Mill, Scheler, Kotarbiński and Wojtyła. As explained in the core curriculum: "The selection of authors and suggested issues that are worth discussing with pupils are explained as follows:

1) these issues are a good illustration for many important ethical issues that find expression in the core curriculum;

2) becoming acquainted with the selected views of great thinkers, the pupil realizes that many momentous moral problems have already been the subject of thorough reflection and one can use this extremely valuable cultural heritage nowadays;

3) knowledge of historically important ethical ideas is an inalienable component of comprehensive education" 28 .

The above-mentioned optional character of the last two sections of the core curriculum for senior grades of primary school means that the teacher should each year complete with pupils at least three selected moral problems of the seventh chapter and at least three elements of ethics history, introducing this content from the sixth grade of primary school. It is recommended that the teacher introducing selected elements of ethics history use short fragments of classical texts.

\subsection{Secondary school}

In the Regulation of the MEN of January 30, 2018 for secondary schools, as for primary schools at the second stage, ethical education is mainly assigned practical sig-

\footnotetext{
27 Ibidem, p. 202.

${ }^{28}$ Ibidem, p. 208.
} 
nificance. ${ }^{29}$ Nevertheless, the content of ethical instruction is further advanced. It manifests itself in a clear emphasis on the theoretical and philosophical specificity of ethical education. According to the creators of the mentioned document, thanks to the combination of both these dimensions, i.e. practical-educational and theoretical-philosophical, teaching ethics is to contribute to the development of students in the skills of moral and ethical thinking, "whose essence is the constant interaction between theorizing and practical performance." ${ }^{30}$ It is worth noting that due to the theoretical emphasis of the ethical education, two aspects were distinguished: hermeneutic and emancipatory. The first is about achieving goals related to understanding the pupil him/herself and the world, while the second is about strengthening his/her autonomy. ${ }^{31}$

Regarding the organizational side, ethics as teaching subject is offered in secondary schools only in the basic range. This regulation probably results from a limited number of hours that the headmasters dispose in relation to the optional school subject.

As at the second stage of primary school, the learning objectives have been grouped into four areas. They are described by the following titles: "Identity, subjectivity and moral development", "Ethical knowledge", "Discussing moral views" and "Self-education". ${ }^{2}$ Along with the core curriculum for primary school, instead of the expected dispositions regarding the issue of ethics classes in the section entitled "Course content", the effects (achievements) that are expected from pupils are presented. This part has been divided into two sections: (1) elements of general ethics and (2) selected issues of applied ethics.

The first section contains two subdivisions entitled: "Basic ethical knowledge" and "Analysis of human action under the moral aspect", for which a total of 18 learning outcomes were scored. ${ }^{33}$ The second section lists six specific areas, which are labelled as follows: "Ethics of personal (individual) life", "Bioethics", "Social and political ethics", "Ethics - science - technology", "Ethics and environment" and "Ethics of different professions". For each area, 3 to 18 learning outcomes have been verbalized. The presentation closes with a list of readings recommended for use in discussing selected ethical issues. This list includes only 8 items that deserve to be called classic. ${ }^{34}$

In the "Basic ethical knowledge" subsection, it is expected that the pupil can explain what ethics does as a science and what types of ethical reflection are. (S)He should also be able to analyse and explain the relationship between ethics, morality,

29 Rozporządzenie Ministra Edukacji Narodowej z dnia 30 stycznia 2018 r. w sprawie podstawy programowej kształcenia ogólnego dla liceum ogólnokształcącego, technikum oraz branżowej szkoły II stopnia, Dz.U. z 2018 r., poz. 467.

${ }^{30}$ Ibidem, p. 22.

${ }^{31}$ Ibidem, p. 23.

${ }^{32}$ Ibidem, pp. 324-325.

${ }^{33}$ Ibidem, pp. 325-326.

${ }^{34}$ Ibidem, pp. 326-328. 
customs, law and religion. In addition, (s)he should be able to explain the concept of moral norm and present the origin of selected moral norms. The range of skills expected from him/her also includes explaining the concept of a person, the relationship between anthropological and ethical decisions, defining terms specific to different ethical positions, identifying the main types of ethical reflection and applying the selected ethical theory to analyse a given moral issue. The level of expectations regarding effects (achievements) in this part of the core curriculum is very high. This raises the rhetorical question: is it possible and to what extent it can be realized at all if one takes into account the organizational conditions of the ethics teaching in public education?

\section{Conclusion}

In the Polish educational system, ethics as a separate subject entered schools only at the beginning of the 90s of the last century. However, an increasing number of primary and secondary school pupils are not attending either ethics classes or religion classes. It must be stated that this creates an increasing gap in their preparation for life in a democratic community what is the task of public education system. Ethics instruction takes three forms in the Polish educational system: (1) one of the thematic areas of integrated early education, (2) a separate learning and teaching subject in older classes of primary school and (3) introductory course on philosophical ethics in secondary schools.

It seems that ethics as a subject of school education lacks grounding from the side of educational science(s). Such grounding means developing strictly pedagogical arguments justifying the need for ethical education and its task in the public education system in Poland.

\section{Bibliography}

Benner D. et al., Kształcenie - moralność - demokracja. Teorie i koncepcje wychowania i kształcenia moralno-etycznego i ich związki z etyka i polityka, Warszawa 2018.

Benner D., Nikolova R., Stan umiędzynarodowienia badania ETiK i jego koncepcja teoretyczno-empiryczna, "Forum Pedagogiczne", 2016, 2 (1), pp. 19-35.

Bodnar A., Dostępność lekcji religii wyznań mniejszościowych i lekcji etyki w ramach systemu edukacji szkolnej. Analiza i zalecenia, "Biuletyn Rzecznika Praw Obywatelskich”, 2015, 6. Retrieved March 1, 2020, from: https://www.rpo.gov.pl/ sites/default/files/BIULETYN RZECZNIKA PRAW OBYWATELSKICH $2015 \mathrm{nr}$ 6.pdf. 
Bodnar A., RPO w sprawie szkół, uczniów, rodziców i nauczycieli. Przykłady spraw z kadencji 2015-2019, 2019. Retrieved March 1, 2020, from: https://www.rpo. gov.pl/sites/default/files/RPO w sprawie szkół.pdf.

CBOS, Młodzież 2018, M. Grabowska, M. Gwiazda (eds.), Warszawa 2019.

Etyka w Szkole (n.d.). Retrieved March 1, 2020, from: https://www.etykawszkole.pl/.

Hejnicka-Bezwińska T., Praktyka edukacyjna w warunkach zmiany kulturowej (w poszukiwaniu logiki zmian), Warszawa 2015.

Madalińska-Michalak J.M., Jeżowski A.J., Etyka i religia jako przedmioty nauczania: konkurencyjność czy komplementarność? "Forum Oświatowe”, 2018, 30 (2), pp. 219-241. Retrieved March 1, 2020, from: http://forumoswiatowe.pl/index.php/czasopismo/article/view/655/416.

Madalińska-Michalak J.M., Jeżowski A.J., Więsław Sz., Etyka w systemie edukacji w Polsce, Warszawa 2017.

Muszyński H., Wychowanie moralne w zespole, Warszawa 1974.

Rozporzadzenie Ministra Edukacji Narodowej z dnia 1 sierpnia 2017 r. w sprawie szczegółowych kwalifikacji wymaganych od nauczycieli, Dz.U. z 2017 r., poz. 1575.

Rozporzadzenie Ministra Edukacji Narodowej z dnia 14 kwietnia 1992 r. w sprawie warunków i sposobu organizowania nauki religii w szkołach publicznych, Dz.U. z 1992 r. Nr 36, poz. 155.

Rozporzadzenie Ministra Edukacji Narodowej z dnia 14 lutego 2017 r. w sprawie podstawy programowej wychowania przedszkolnego oraz podstawy programowej kształcenia ogólnego dla szkoły podstawowej, w tym dla uczniów z niepetnosprawnością intelektualna w stopniu umiarkowanym lub znacznym, kształcenia ogólnego dla branżowej szkoły I stopnia, kształcenia ogólnego dla szkoły specjalnej przysposabiającej do pracy oraz kształcenia ogólnego dla szkoły policealnej, Dz.U. z 2017 r., poz. 356.

Rozporządzenie Ministra Edukacji Narodowej z dnia 25 marca 2014 r. zmieniajace rozporządzenie w sprawie warunków i sposobu organizowania nauki religii w publicznych przedszkolach i szkołach, Dz.U. z 2014 r., poz. 478.

Rozporzadzenie Ministra Edukacji Narodowej z dnia 30 stycznia 2018 r. w sprawie podstawy programowej kształcenia ogólnego dla liceum ogólnokształcącego, technikum oraz branżowej szkoły II stopnia, Dz.U. z 2018 r., poz. 467.

Sprawa Grzelak przeciwko Polsce (skarga nr 7710/02). Retrieved March 1, 2020, from: http://trybunal.gov.pl/polskie-akcenty-w-orzecznictwie-miedzynarodowym/ rada-europy-europejski-trybunal-praw-czlowieka/w-sprawach-polskich/ art/8251-sprawa-grzelak-przeciwko-polsce-skarga-nr-7710-02-wyrok-z-15czerwca-2010-r/.

Stępkowski D., Kształcenie religijne w publicznym interesie. Perspektywa pedagogiki ogólnej, "Przegląd Pedagogiczny", 2018, 2, pp. 103-119. 
Stępkowski D., School Moral Education: Does Scholastic Ethical Instruction Need Its Own 'Morality'?, [in:] Kudláčová B., Rajský A. (eds.), Education and "Pädagogik" - Philosophical and Historical Reflection, Berlin 2019.

Suchodolski B., O program świeckiego wychowania moralnego, Warszawa 1961. 
Agnieszka Gąstoł* (iD http://orcid.org/0000-0002-1148-4499

Akademia Pedagogiki Specjalnej im. Marii Grzegorzewskiej w Warszawie

https://doi.org/10.25312/2083-2923.17/2020_02ag

\title{
Children creating a mess: what underlies this phenomenon in kindergarten pupils?
}

\begin{abstract}
The article contains a discussion about the problem frequently observed by parents and teachers regarding small children and their inability to be tidy in self-care situations, while playing or following instructions given by adults. The article contains an overview of theories helping to elucidate the occurrence of such problems among kindergarten pupils and children setting off to begin their primary school education. The author of the text focuses particularly on children's individual predisposition to benefit from instruction given by adults and the schema theories, especially the concept of scripts, plans and themes elaborated by Schank and Abelson.
\end{abstract}

Keywords: children making a mess, children's theory of mind, cognitive schemas

\section{Introduction: children making a mess, the origin of the concept and its application}

The term children making a mess was first introduced in Polish pedagogical discourse by Edyta Gruszczyk-Kolczyńska in November 2009 during an international conference organized in Kraków by the Association for Children with Genetic Disorders GEN and the Department of Special Education at the Adam Mickiewicz Univer-

\footnotetext{
* Agnieszka Gąstol, MA, is a psychologist, psychotherapist, special education teacher with several years of professional experience working in psychological and pedagogical counselling centres and mental health clinics. She is a research assistant in the Department of Early Childhood Education of the Institute of Assisted Human Development and Education at the Maria Grzegorzewska Academy in Warsaw. She is the author of books and articles on supporting child and family development. Specialized in working with children and young people with emotional disorders and families in a situation of separation. Her research interest focuses on the phenomenon of children who create a mess.
} 
sity of Poznań ${ }^{1}$. The term was employed in reaction to a pedagogical study which resulted in heightened attention being given to a specific group of kindergarten pupils. Even though its originator claims that the problem of making a mess refers to older kindergarteners (five- and six-year-olds), the habit is formed a lot earlier ${ }^{2}$. According to Gruszczyk-Kolczyńska's findings, children making a mess having performed some simple actions, lose interest in what they are doing, abandoning objects, or suddenly stop half-way through what they were saying and change the topic. The above definition pertains to only one type of behaviour from a whole range demonstrated by such children, which constitute an actual impediment in their benefitting from kindergarten education.

However, after an in-depth analysis of related literature I have come to the conclusion that the problem was not discussed or elaborated on by anyone apart from the aforementioned author. It is astounding, especially since such behaviour is now often manifested by kindergarteners, according to many teachers. School teachers point to the fact that an increasing number of children find it difficult to organize their work space properly or perform tasks with several components, being generally untidy and sloppy. This growing tendency cannot be explained only with overcrowded classrooms, short breaks between lessons, or classes spread out unevenly in the school week.

An analysis of home environments of the children concerned reveals that their behaviour at home is similar: they follow only simple instructions, leave objects wherever they stand, and while changing literally throw things off and drop them on the floor. Parents, on the other hand, are constantly critical of their children's behaviour, following them around and tidying up the mess they leave behind, help them get dressed or feed them. In their opinion such assistance is a faster, more peaceful and less troublesome option. Moreover, parents tend to justify their children (and themselves), saying, for instance: "he is still too small; he's got time; he will learn later; he always does so; that's the way he is; his father and grandfather were the same as kids; you have to do everything for him anyway". The types of behaviour demonstrated by the children's guardians, which the researcher was able to determine on the basis of short interviews and conversations, are characterised by impatience, simplification of self-care activities to the bare minimum, as well as ignoring the necessity to teach children orderliness in their surroundings.

What is more, Gruszczyk-Kolczyńska managed to determine the scale of the problem - having interviewed some of the kindergarten teachers she was able to find that there are several such children in every group of kindergarteners. The number of

${ }^{1}$ E. Gruszczyk-Kolczyńska, Krótkie wykłady o dobrym wychowaniu. O dzieciach siejących bałagan. Jakie są tego przyczyny i w jaki sposób można to zmienić na lepsze, "Bliżej Przedszkola", 2010, 11. Retrieved Feb 15, 2020, from: https://blizejprzedszkola.pl/o-dzieciach-siejacych-balagan,2,83. $\underline{\text { html\#. }}$.

${ }^{2}$ E. Gruszczyk-Kolczyńska, E. Zielińska, Dwulatki i trzylatki w przedszkolu i w domu. Jak świadomie je wychowywać i uczyć, "Bliżej Przedszkola”, 2012, p. 132. 
such children is growing. From the information she collected from parents and teachers, the above-mentioned children do not manifest permanent change in behavioural patterns after being admonished or offered assistance by adults. They constantly copy their way of behaviour and, as a consequence, form and consolidate improper habits.

\section{What underlies the creation of mess in kindergarten pupils?}

It is indeed fascinating that some children can accept kindergarten rules easily and master the skills required of them, while others find it extremely difficult to abide by the rules.

My research has revealed that the discrepancy can be effectively clarified by means of five theories: individual predisposition to benefit from instruction given by adults, expectations theory, self-verification, symbolic interactionism and children's theory of mind.

\section{Susceptibility to learning, expectations theory, self- verification and symbolic interactionism: social conditions of children making a mess}

Susceptibility to learning is treated as an individual ability. That is why, to determine its scope, one has to refer to the analysis of repetitions necessary for a child to master a specific activity in a similar situation. At one end of the continuum one can find children who need three or four repetitions to master a complex activity, while at the other - children who need more than a dozen repetitions ${ }^{3}$. What this means in practice is that there are children who, having been familiarised with a series of consecutive actions, understand instantly why they need to perform them and can copy them without error. All they need, in fact, is a hint to be able to carry out the actions better every time, being more and more self-reliant. At the same time, there are children who require for the complex action to be divided into a series of simple activities, and after that to be guided on how to proceed and repeat them many times, to be finally able to efficiently perform the complex task on their own.

Expectations are subjective assessments of the likelihood of a specific gain occurring after a particular behaviour. It is also a factor whose knowledge makes it possible to predict the behaviour of other people in the environment. When entering into relationships with people, there is a tendency to create specific expectations about

${ }^{3}$ Z.I. Kałmykowa, Metodika diagnostyki obuczajemostii szkolnikow: na materiale fizyki. Obuczajemost w principy postrojenija metodow jejo diagnostyki, [in:] Problemy diagnostyki umstwiennowo razwitija uczaszczichsja, Moskwa 1975, according to: E. Gruszczyk-Kolczyńska, Jak dzieci dowiadują się, co można, a czego nie można. O wychowaniu zamierzonym i niezamierzonym, „Bliżej Przedszkola”, 10, pp. 10-14. 
their motivations, attitudes and behaviours. Although most of them are created unconsciously, they form the basis of people's intentional behaviour. The arising expectations have a rigid and hardly changeable structure, this happens if they are based on cognitive patterns.

According to psychologists Edward Jones and Daniel McGillis, there are two types of expectations. The first - created on the basis of information about a person's belonging to a given social group (expectations based on category), the second - created on the basis of characteristics and behaviours disclosed by a person in various situations over time (expectations based on an object). In the same way, there are also two ways of communicating them - directly (this happens when a child hears from a parent or teacher that they cannot cope with the task because they have less talent than other children) and indirectly (using non-verbal, subtle signal, even unconscious, like in the situation when a parent persistently ignores children's queries or requests for help.

There is a theory directly related to expectations known as the self-fulfilling prophecy, or as the Rosenthal or Pygmalion effect ${ }^{5}$. It concerns the relationship between social perception and behaviour undertaken towards other people.

${ }^{4}$ E. Jones, D. McGillis, Correspondent inferences and the attribution cube: A comparative reappraisal, [in:] J.H. Harvey, W. Ickes, R.F. Kidd (eds.), New directions in attribution research, vol. 1, Erlbaum, Hillsdale 1976, pp. 389-420 according to: S. Trusz (eds.), Efekty oczekiwań interpersonalnych. Wybór tekstów, Wydawnictwo Naukowe Scholar, Warszawa 2013, p. 41.

${ }^{5}$ R. Merton, The Self-Fulfilling Prophecy, “The Antioch Review”, 1948, 2 (8), pp. 193-210. This effect was first described by sociologists William Isaac Thomas and Robert Merton in 1948. Both claimed that if a person sees the situation as real, it is also true in its consequences. This expectation effect was originally described in the context of the research process. It is the researcher's unconscious tendency to act and to make interpretations during the research process in such a way as to gain confirmation of his/her own hypothesis. An experiment showing the occurrence of this effect on educational grounds was described by Robert Rosenthal and Leonora Jacobson. In primary school, children were tested with an intelligence test designed in such a way that the result could indicate the developmental possibilities of the student. From each of the 18 studies classes, 1/5 of the pupils were selected for the experimental groups, which were presented to the teacher as predestined to achieve high school results over the next 8 months. The control group consisted of other children. In practice, therefore, differences between groups existed only in the minds of teachers. After the assumed time, the children were subjected to another examination, which revealed that children with low abilities (included in the test) obtained good results when the teachers expected them to (R. Rosenthal, L. Jacobson, Self-fulfilling prophecies in the classroom: Teachers' expectations as unintended determinants of pupils' intellectual competence, [in:] M. Deutsch, I. Katz, A.R. Jensen (eds.), Social class, race and psychological development, Holt, Rinehart \& Winston, New York 1968, pp. 219-253). School influences students' "achievements through teachers' expectations" (P. Cuttance, Do schools consistently influence the performance of their students?, "Education Review" 1977, 29 , pp. 317-325). However, this works in two directions - the teacher's high expectations towards the child allow him/her to achieve greater achievements (Galatea effect), while low expectations delay his/her achievements (Golem effect) (E.Y. Rabad, J. Inbar, R. Rosenthal, Pygmalion, Galatea and the Golem: Investigations of biased and unbiased teachers, "Journal of Educational Psychology" 1982, 74, pp. 459-474). 
Self-fulfilling prophecy reveals itself when three conditions are met. The first when the teacher or parent creates false expectations in their minds about the child (most often they have their source in cognitive schemes, for example, shared by general stereotypes about gender, personal characteristics or motivation). The second is to reveal these expectations to the child in a more or less subtle way, e.g. with the comment "you are the same as your father", "girls are not fit for such things" or with the help of non-verbal signals, i.e. body shapes, facial expressions or gestures. And finally - the third condition - confirmation in the child's behaviour of earlier expectations of parents and teachers, which will happen if a child suspected of clutter once again does not maintain order around him or when the adult interprets his attempt to keep order as a failure, i.e. behaviour in accordance with the original expectation.

This theory can to some extent explain the behaviour of adults towards children who create a mess, which contributes to the persistence of the problem. Due to the fact that in the very definition of creating a mess, I emphasize that these children constantly ignore rules and order. The repetition of these behaviours may give rise to specific expectations on the part of adults. It works in two directions - on the one hand, adults expect young children to be able to effectively organize the space around them, maintaining order during activities. On the other hand, adults, seeing the child's awkwardness in carrying out tasks, perform tasks instead of the child or provide him/her with such far-reaching help that the child only has to submit to them.

The theory of symbolic interactionism should be included here. It states that behaviours are always interpreted before people react to them in a specific way. If the adult's behaviour expresses his/her beliefs and permanent dispositions, it directly affects his/her expectations of the child regarding the nature of his/her subsequent behaviour ${ }^{6}$. According to this theory, it can be assumed that children predict that adult behaviour towards them will be repeated (e.g. differences in the treatment of children who create a mess and their peers who do not). The mechanism of equalizing attitudes between the behaviour of an adult and a child tends to be similar, hence the unfavourable behaviour of parents and teachers towards children who are messing will be compounded by the number of behaviours presented by children that involve not maintaining order around themselves.

And vice versa - changing adults' behaviours to more favourable ones can cause equally favourable reactions from children. Of course, this does not mean that making a mess seems to be conditioned only by the expectations of adults, but the impact of this phenomenon on the persistence of the problem of clutter should be taken into account.

${ }^{6}$ R.H. Fazio, J.M. Darley, Expectancy confirmation processes arising in the social interaction sequence, "American Psychologist" 1980, 35 (10), pp. 867-881, see also: D.W. Jamieson et al., Pygmalion revisited: New evidence for student expectancy effects in the classroom, "Journal of Educational Psychology" 1987, 79 (4), pp. 461-466. 
Finally, it should be considered how the child's self-attributes, according to the expectations of adults, affect their explanation of their own successes and failures, i.e. the construction of their own self. Children who create a mess, consistently treated by adults in a differentiated way (e.g. in a kindergarten group by teachers, or in comparison to their siblings in the family home), after some time, may come to the conclusion that their behaviour accurately reflects their character traits or skill level, for example, "if the teacher keeps telling me I'm doing wrong and I will never learn order, it means I can't do it and I'm a mess". In this case, the scope of confirmation will increase in each subsequent situation of a similar nature, making adult expectations consistent with a childish pattern. As demonstrated by William B. Swann and Robin J. Ely, confirmation occurs when adults who witness the observed behaviour are confident in their own expectations, while children presenting specific behaviour - uncertain of their own self 7 . Importantly, it should be remembered that adult expectations may be the result of cognitive distortions resulting from their own developmental experiences and that the level of perceived similarity in the area of behaviour, personal characteristics or external appearance (e.g. "he is the same as me his age") may intensify behaviour patterns that are characteristic of high or low expectations ${ }^{8}$.

What is important in the phenomenon of children making a mess is that they do not change their behaviour. Adults are torn between two desires. On the one hand, they are aware and want the child to be independent, on the other hand, they love them immeasurably, they want to take care of him/her, "because he/she is still so small", to help him and spare him unpleasant situations. Children see this dilemma and do not change their behaviour, because they anticipate in their mind that adults will help them anyway, and in the end they will give praise and love, kisses and hugs.

\section{The way in which children put together conceptual knowledge of the world - children's theory of mind}

Ever since the bloom of developmental psychology scholars have been fascinated with the way children acquire knowledge about their surroundings. The variety of speculation, hypotheses and research led to the birth of children's theory of mind $^{9}$. In

7 W.B. Swann, R.J. Ely, A battle of wills: Self-verification versus behavioural confirmation, "Journal of Personality and Social Psychology" 1984, 46, pp. 1287-1302, according to: S. Trusz (ed.), Efekty oczekiwań interpersonalnych..., op. cit., p. 45.

${ }^{8}$ R.C. Rist, Student social class and teacher expectations: The self-fulfilling prophecy in ghetto education, "Harvard Educational Review" 1970, 40, pp. 411-451.

9 The term "theory of mind" was coined by David Premack and George Woodruff in 1978. ToM was submitted to wide and detailed analysis in the 1990s. From a wider perspective it provides information on the workings of the mind and in a narrower sense it refers to abstract causal and explanatory systems which allow children to effectively predict and express emotions along with voicing needs. 
related literature the term is used to cover many different phenomena pertaining to reasoning. Its most modern definition describes theory of mind as an intuitive comprehension of one's own mental states as well as those of others ${ }^{10}$, which corresponds with the term "mental imagery"11 (deriving from the theory of Jean Piaget, who was the forerunner of this approach). The gradual development of images, from reproducing to anticipatory and from static to kinetic, until the final emergence of actual representation in the form of transformative images in the concrete operational stage, paves a child's way, in the process of development, to making use of logical structures of reasoning, allowing them to construct a fully coherent knowledge about the world. The process of arriving at such knowledge is a result of a child's individual activity ${ }^{12}$, as a consequence of which the representation of the world is formed through a system of internal symbols and codes. The above representation is both knowledge itself, as well as the way in which it is later organised, and subsequently defines cognitive development as moving from the level of procedural knowledge, which refers to the way we behave in our environment - "I know how", to declarative knowledge, connected to the way we reflect on the actual world - "I know that"13. The spokesman for the constructivist theory of the manner in which children arrive at their image of the world - Jerome Bruner, enumerates three modes of representation: enactive (understanding events on the basis of actions leading to them); iconic (based on images as equivalents of objects and events); and symbolic (representing experience through ideas $)^{14}$. If we explore Bruner's theory further we will discover that, while obtaining information in the manner mentioned above, human beings revert to two modes of thought - paradigmatic and narrative. The first of these is based on logical reasoning and helps describe reality in an objective way, while the other refers to the realm of intentions, needs, emotions and beliefs - the subjective mode of reasoning. Both ground-breaking theories presented here introduce a distinction between the way children think about the world of objects and the internal world, which justifies the need for further study in the area of the children's theory of mind.

Here one should mention the most renowned researchers in the field: Katherine Nelson, Jean M. Mandler, Anette Karmiloff-Smith, as well as Roger C. Schank and Robert P. Abelson.

10 R. Schaffer, Psychologia rozwojowa. Podstawowe pojęcia, Wydawnictwo Uniwersytetu Jagiellońskiego, Kraków 2010, p. 134.

11 J. Piaget, B. Inhelder, Od logiki dziecka do logiki młodzieży: rozprawa o kształtowaniu się formalnych struktur operacyjnych, PWN, Warszawa 1970, p. 137.

12 M. Białecka-Pikul, Co dzieci wiedzą o umyśle i myśleniu. Badania i opis dziecięcej reprezentacji stanów mentalnych, Wydawnictwo Uniwersytetu Jagiellońskiego, Kraków 2002, p. 12.

${ }^{13}$ K. Stemplewska-Żakowicz, Osobiste doświadczenia a przekaz społeczny. O dwóch czynnikach rozwoju poznawczego, Wydawnictwo Leopoldinum, Wrocław 1996, p. 68.

14 J. Bruner, Poza dostarczone informacje, PWN, Warszawa 1978, p. 534. 
However, a full understanding of the idea behind each of the theories presented above requires the clarification of their key term - schema - since it is one of the most often misused terms in psychology.

Schema theory draws on three components: constructivism, the poverty of stimulus argument, reconstructive hypothesis, stereotyping, the assumption of graceful degradation of an output, and the principle of cognitive economy ${ }^{15}$. The outside world is constructed in the mind thanks to the interpretation of stimuli retrieved from sensory receptors and then granted meaning based on our personal beliefs, goals and expectations. Thus, every human being, having experienced different things, carries a different representation of reality in their minds - a phenomenon called constructionism by scholars dealing with the issue. However, the information humans receive from their sensory receptors often provides them with very poor content - at times being too meagre to give foundation to an adequate recognition of an object or a situation. This is why the human mind completes the data with so-called default values which are both different and specific to each and every individual person, because they are based on our attitude and expectations. The poverty of stimulus argument, however, points to the fact that the poorer the data coming from our sensory receptors, the greater the risk of an inappropriate interpretation of such data. Whatever human beings perceive is then stored in their memory system and reconstructed in a specific, adequate situation. Information retrieved from long-term memory does not remain unchanged and constant after it has been moved to short-term memory. Additionally, such retrieval depends on individual attitudes, beliefs and goals. As a consequence, memory recall is in fact a particular kind of reconstruction of the registered data, and not its mechanical reproduction. Thus, the information gathered in long-term memory serves merely the function of building material in the process of memory retrieval - a phenomenon given the name of reconstructive hypothesis by Ulric Neisser ${ }^{16}$. However, the constantly recalled memories tend to move further and further away from the reality of perceived events or actors and shift towards traits characteristic for a specific category, which is a process called the stereotyping of memory. The assumption of graceful degradation of an output explains why humans undertake reasoning and, subsequently, action even though they have insufficient premises at their disposal. Referring to a computer metaphor often used to introduce schema theory, one should expect that incomplete information based on an insufficient amount of data obtained from sensory receptors will lead to abandoning any attempts at reasoning or action - as would be the case should the decision be taken by a computer programme (rapid degradation of an output). Nevertheless, humans will provide a solution even if they are not in possession of complete

${ }^{15}$ K. Najder, Schematy poznawcze, [in:] M. Materska, T. Tyszka, Psychologia i poznanie, PWN, Warszawa 1997, p. 38.

${ }^{16}$ According to: K. Najder, Schematy poznawcze, [in:] M. Materska, T. Tyszka, Psychologia i..., op. cit., p. 40. 
data. Results arrived at in this manner are degraded, but are revealed even if they are "worse". One must also remember that human cognitive make-up is designed at being maximally useful with a minimal amount of effort made. The effort in this case is the number of procedures needed for achieving a particular result. Following the principle of cognitive economy, human memory must be organised in a way allowing for the shortest possible searching time, elimination of unnecessary data, and reduction of procedures carried out in order to arrive at the most relevant outcome - which in practice means attempts at reasoning and undertaking actions.

On the basis of the above-mentioned components, one can introduce a definition of cognitive schema understood as a module of the cognitive system designed to construct perception- and memory-based representations of a particular category of objects or events. It contains data both in the form of default values (hypotheses) which refer to these objects or events, as well as procedures useful for selecting some values and assuming other values simultaneously ${ }^{17}$.

On the basis of the studies conducted by the above-mentioned authors, Katherine Nelson points to the existence of script-like forms of organizing knowledge gained by children. Her findings suggest that the representation of the world is subject to gradual modification with the increasing quantity of experience. At the beginning, the generated sequence of events becomes longer; after that the order in which they are given is arranged; the number of elements not specific for a given situation is reduced; and finally conditional connections are created - crucial for the emergence of alternative paths in the script. The very structure of a script remains essentially unchanged; what changes are the representations - a phenomenon which is understood as the process of creating categories. According to Nelson, categories can be derived from several scripts containing the same variable (meta-script connections) ${ }^{18}$.

Nelson's assumption of the universal (to children and adults alike) structure according to which representations are formed was further supported by Jean M. Mandler, who emphasised the significance of "structural invariants". In the course of developing, the knowledge of the "that" type is derived from the knowledge of the "how" type, which happens as a result of various procedures available through an experience-search conducted by both children and adults. The increasing amount of such procedures leads to them becoming automatic, objective, and the subsequent incorporation into operational systems at a higher level ${ }^{19}$.

According to Annette Karmiloff-Smith, a situation in which procedures become automatic leads to the activation of a "meta-procedural operator" designed to coor-

${ }^{17}$ Ibidem, p. 43 .

${ }^{18}$ K. Nelson, Cognitive development and the acquisition of concepts, [in]: R.C. Anderson, R.J. Spiro, W.E. Monague (eds.), Schooling and the acquisition of knowledge, Lawrence Erlbaum Associates, Hillsdale New Jersey 1977.

19 See more: J.M. Mandler, Stories, scripts and scenes. Aspects of schema theory, Lawrence Erlbaum Associates, Hillsdale New Jersey 1984. 
dinate and integrate the initially disconnected procedures. It suggests the transition from implicit to explicit representations ${ }^{20}$. Implicit knowledge is inscribed into procedures designed to attain this goal, and single components cannot be retrieved and compared with identical fragments of other procedures. This is because components function only within the scope of the particular procedures. However, as soon as they become automatic they are moved to the explicit kind of knowledge and they become recorded there. Unfortunately, this second stage is exposed to errors which might emerge in the course of such processing. While using data available in the implicit form, children are aware of the fact that it is in itself a potentiality on the road to realizing a given amount of information, which in turn is an evidence of "metacognition".

\section{Scripts, plans and themes theory: how a child imagines the world}

The analysis of possibilities and limitations of the concept that would explain the occurrence of clutter-like behaviours in children has led me to a theory that seems to be the most accurate explanation of why it happens that a group of children has trouble maintaining order around them, while being highly resistant to upbringing correction on the part of adults.

Schema theories, and especially the concept of scripts, plans and themes, help to explain why older kindergarteners make such a big mess in their surroundings. What distinguishes this theory, developed by Roger Schank and Robert Abelson, from other schematic concepts, in my opinion is the emphasis on the importance of situational context for the development of a given skill. Schank and Abelson elaborated three main groups of schemata: scripts, plans and themes ${ }^{21}$. Scripts represent events which - from the perspective of the actor - seem to be repeated with a very high frequency. A script contains sets of default scripts of the event which are similar to a plan of a sequence of scenes. An appointment at the doctor's, using the toilet or having a meal can all serve as examples of a script. Plan is a more general schema in comparison with a script. It contains information on the way the actors of the scene achieve their goals, for instance: a plan to treat one's illness (more general in comparison with the script of a doctor's appointment); a plan to meet one's physiological need (more general in comparison with the script of using the toilet); and finally, a plan to satisfy one's hunger (more general in comparison with the script of having a meal). According to Schank and Abelson, a plan helps to understand the events for which a person has no ready scripts prepared. The third group of schemata - themes - are

${ }^{20}$ See more: A. Karmiloff-Smith, Beyond Modularity: a developmental perspective on cognitive science, A Bradford Book. The MIT Press, London 1992.

${ }^{21}$ See more: R. Schank, R. Abelson, Scripts, Plans, Goals and Understanding. An Inquiry into Human Knowledge Structures, Erlbaum, New Jersey 1977. 
of a superordinate nature. This group defines the goals of the actors in various social situations. The goals of kindergarteners will thus be different from those of pupils, teachers, or parents.

The scripts resemble scenarios according to which the child organizes its purposeful activities in certain conditions. They contain knowledge such as: "it must be done to achieve the goal..., "it usually happens in such a way...", "this is what you can expect.... Each of these scenarios always includes:

- a repetitive situational context, i.e. a scene;

- props that occur in a given situation (i.e. the environment and the objects it contains);

- actors, i.e. participants in situations that make it possible to achieve the goal;

- specific sequences of actions necessary to achieve the intended goal.

A well-formed script helps the individual to perform activities in a way which meets expectations, and with minimal effort, time and energy spent. Thanks to that, children can take care of their needs and simultaneously analyse interesting questions in their minds.

Script modification consists of: changing the sequence of activities to new ones, taking into account acquired knowledge about different conditions in which we can achieve the goal and the need to include the core activity sequence for the script. For example - when visiting a museum, seeing the inscription "cloakroom", we know that there you should undress. We don't have to think about it more accurately, and our thoughts can then be focused around completely different topics. The less effective the script is, the more often the child will try other behaviours to achieve the intended effect. By introducing modifications - the child gradually develops scripts. However, the more precise the scripts are and the faster the child can apply them in a new situation, the greater his/her functioning and causative capabilities.

\section{The application of the theory in research on children who make a mess}

Gruszczyk-Kolczyńska, looking at the functioning of children who create a mess, has concluded that scripts are being built in their minds in a faulty way. The educational errors and short-sightedness described earlier show that adults prefer to teach children a series of simple tasks here and now, ignoring everything around them ${ }^{22}$. In the long run, this results in the formation of rigid and non-functional habits, which are much more difficult to change later. To understand this, let us focus on the example of having lunch in kindergarten. Everyone must eat to survive (theme), to achieve this one must implement the plan to satisfy hunger. Depending on your experience, it has a more or less extensive meal script.

${ }^{22}$ E. Gruszczyk-Kolczyńska, Dwulatki i trzylatki w przedszkolu i w domu..., op.cit., p. 140. 
Barbara, a five-year-old in a kindergarten group, takes a place at the table. The girl has a well-developed meal script. She knows that you should wait until the cook puts a plate of soup in front of you. She can choose the right cutlery and use it efficiently. She says "bon appétit". She eats in peace - carefully, without looking around, does not spill or talk. After the meal is over, she wipes her mouth with a napkin, says "thank you, I liked it", puts the plate back in its proper place, moves the high chair and sits on the carpet in its place waiting for other children. Barbara was taught by her parents and guardians of cultural behaviour at the table, in accordance with generally accepted social norms, hence the implementation of this script in kindergarten does not cause her difficulties. The girl has a well-developed situational script. She performs it mostly automatically.

Christopher - who had completely different habits in his family home, i.e. ate in a place of his choice (and not together with other household members), played with food, frowned, talked during a meal, got up from the table when he spilled soup (the carers wiped the mess he made); when he ate, he stood up without a word, leaving the plate when he finished eating, letting the adults do the rest for him; he never wished others 'bon appétit' and or offered thanks for the meal. In kindergarten he will behave similarly. This will result in the teacher paying attention to him, instructing him, constantly suggesting activities. The boy does not have a properly built situational script. He seems to use a personal script to a greater extent, depending on his mood and impulsive desires.

This does not mean that Christopher will not follow the correct script. Having possibilities and limitations of script theory, plans and topics, and regularities governing the formation of habits, Christopher's behaviour can be changed. However, in order to be able to plan corrective actions effectively, one needs to thoroughly understand the specifics of children messing up, including: individual children's difficulties and limitations as well as all external stimuli affecting the persistence of incorrect patterns.

\section{Conclusion}

The phenomenon of children making a mess seems to derive from problems centred on their formative and educational environment. Meticulous study of the rules according to which the knowledge of the surrounding world is formed in the mind of a child can help researchers to elaborate solutions improving everyday functioning of such children and result in the implementation of effective remedial actions which can be taken both at home and in the kindergarten.

The aim of this article was to indicate which theories may shed light on the behaviour of making a mess, especially as there are more and more children having this problem. The presented theories, especially scripts, plans and themes theory, give an 
excellent explanation of this phenomenon and are useful in constructing corrective actions.

The problem of everyday functioning of these children and their future school fate needs to be deepened, which I have been doing in my academic research for over five years ${ }^{23}$. The data obtained are promising and offer the chance to change for the better the fate of children who create a mess.

\section{Bibliography}

Anderson R.C., Spiro R.J., Monague W.E. (eds.), Schooling and the acquisition of knowledge, Lawrence Erlbaum Associates, Hillsdale New Jersey 1977.

Białecka-Pikul M., Co dzieci wiedza o umyśle i myśleniu. Badania i opis dziecięcej reprezentacji stanów mentalnych, Wydawnictwo Uniwersytetu Jagiellońskiego, Kraków 2002.

Bruner J., Poza dostarczone informacje, PWN, Warszawa 1978.

Cuttance P., Do schools consistently influence the performace of their students?, "Education Review" 1977, 29, pp. 317-325.

Deutsch M., Katz I., Jensen A.R. (eds.), Social class, race and psychological development, Holt, Rinehart \& Winston, New York, 1968, pp. 219-253.

Fazio H., Darley J.M., Expectancy confirmation processes arising in the social interaction sequence, "American Psychologist" 1980, 35 (10), pp. 867-881.

Gruszczyk-Kolczyńska E., Jak dzieci dowiaduja się, co można, a czego nie można. O wychowaniu zamierzonym i niezamierzonym, "Bliżej Przedszkola" 2010, 10, pp. 10-14.

Gruszczyk-Kolczyńska E., Krótkie wykłady o dobrym wychowaniu. O dzieciach siejacych bałagan. Jakie sa tego przyczyny $i$ w jaki sposób można to zmienić na lepsze, "Bliżej Przedszkola", 2010, 11. Retrieved Feb 15, 2020, from: https:// blizejprzedszkola.pl/o-dzieciach-siejacych-balagan,2,83.html\#.

Gruszczyk-Kolczyńska E., Zielińska E., Dwulatki i trzylatki w przedszkolu i w domu. Jak świadomie je wychowywać i uczyć, “Bliżej Przedszkola”, Kraków 2012.

Karmiloff-Smith A., Beyond Modularity: a developmental perspective on cognitive science, A Bradford Book. The MIT Press, London 1992.

Mandler J.M., Stories, scripts and scenes. Aspects of schema theory, Lawrence Erlbaum Associates, Hillsdale New Jersey 1984.

${ }^{23}$ Research was carried out in Warsaw kindergartens among the oldest pupils, their parents and teachers. They allowed an accurate description of the phenomenon of creating a mess, including a detailed presentation of the causes of this phenomenon and the creation of a children's typology. The research results were described in an unpublished doctoral dissertation entitled Children making a mess - application of mind theory in determining causes and corrective actions. 
Materska M., Tyszka T., Psychologia i poznanie, PWN, Warszawa 1997.

Merton R., The Self-Fulfilling Prophecy, “The Antioch Review”, 1948, 2 (8), pp. 193-210.

Nelson K., Cognitive development and the acquisition of concepts, [in]: R.C. Anderson, R.J. Spiro, W.E. Monague (eds.), Schooling and the acquisition of knowledge, Lawrence Erlbaum Associates, Hillsdale New Jersey 1977.

Piaget J., Inhelder B., Od logiki dziecka do logiki młodzieży: rozprawa o kształtowaniu się formalnych struktur operacyjnych, PWN, Warszawa 1970.

Rabad E.Y., Inbar J., Rosenthal R., Pygmalion, Galatea and the Golem: Investigations of biased and unbiased teachers, "Journal of Educational Psychology" 1982, 74, pp. 459-474.

Rist R.C., Student social class and teacher expectations: The self-fulfilling prophecy in ghetto education, "Harvard Educational Review" 1970, 40, pp. 411-451.

Schaffer R.H.R., Psychologia rozwojowa. Podstawowe pojęcia, Wydawnictwo Uniwersytetu Jagiellońskiego, Kraków 2010.

Schank R., Abelson R., Scripts, Plans, Goals and Understanding. An Inquiry into Human Knowledge Structures, Erlbaum, New Jersey 1977.

Stemplewska-Żakowicz K., Osobiste doświadczenia a przekaz społeczny. O dwóch czynnikach rozwoju poznawczego, Wydawnictwo Leopoldinum, Wrocław 1996.

Trusz S. (ed.), Efekty oczekiwań interpersonalnych. Wybór tekstów, Wydawnictwo Naukowe Scholar, Warszawa 2013. 


\title{
Klaudia Smulnik-Barska* (iD) https://orcid.org/0000-0003-4487-3877
}

Uniwersytet Gdański

https://doi.org/10.25312/2083-2923.17/2020_03ksb

\section{Zjawisko "troll parentingu" - modne macierzyństwo, czy forma krzywdzenia dzieci?}

\begin{abstract}
Streszczenie: Troll parenting to powszechne zjawisko oraz codzienny element życia wielu rodzin. Nadmierne wykorzystywanie do publikacji zdjęć dziecka, bez jego zgody, może przejawiać znamiona przemocy emocjonalnej, nawet jeśli rodzic jest tego zupełnie nieświadomy i nie jest jego intencją skrzydzić swoje dziecko. Zamieszczanie zdjęć dziecka na portalach społecznościowych skutkuje również narażeniem go na ośmieszenie, upokorzenie, cyberprzemoc, hejt, a nawet potencjalny atak na tle seksualnym. Niniejszy artykuł analizuje problematykę troll parentigu, potencjalne zagrożenia oraz prezentuje poziom świadomości i stosunek rodziców, będących bezpośrednim lub pośrednim podmiotem tego zjawiska.
\end{abstract}

Słowa kluczowe: troll parenting, krzywdzenie, dziecko, przemoc emocjonalna

Każdego dnia publikowane są setki zdjęć dzieci na portalach społecznościowych, blogach i innych serwisach. Część z nich pojawia się na prywatnych kontach użytkowników, a część w ramach dostępu publicznego. Zdjęcia stanowią pewnego rodzaju komunikat skierowany do innych użytkowników serwisu lub dodatek do publikowanego posta czy innych treści mających na celu polecenie produktu/przedmiotu. Codziennie ukazują się również nowe materiały wideo utrwalające najróżniejsze wydarzenia z życia dzieci. To jest codzienność, którą oferują nam Internet oraz urządzenia cyfrowe i smartfony. Zaczynamy dzień od sprawdzenia, co zostało opublikowane przez na-

" Klaudia Smulnik-Barska - doktorantka Uniwersytetu Gdańskiego, przygotowująca pracę naukową z zakresu karcenia wychowawczego o charakterze fizycznym i psychicznym oraz o wiążących się z nim konsekwencjach karnoprawnych. 
szych znajomych, rodzinę, obserwowane osoby publiczne na Facebooku, Instagramie lub innych portalach. Następnie sami, podążając za tym trendem, dodajemy kolejne treści pokazujące nasze dzieci i ich dzień. Uczestniczenie w życiu wirtualnym stanowi dziś ważny element naszego życia. Nieuczestniczenie w nim bowiem może skutkować wykluczeniem $z$ danego środowiska, posądzeniem o brak umiejętności posługiwania się Internetem czy też po prostu o „bycie nie na czasie/bycie niemodnym”. Troll parenting to powszechnie panujący trend upowszechniania przez rodzica zabawnych czy też nietypowych zdjęć lub filmików z udziałem swoich dzieci. Owa praktyka, która może stanowić ogromne zagrożenie dla rozwoju oraz bezpieczeństwa dziecka, wydaje się nie być przedmiotem badań naukowych. Szczegółowe omówienie zakresu zjawiska oraz jego konsekwencji dla dziecka i rodziny staje się konieczne z punktu widzenia rozwoju narzędzi, aplikacji dostępnych w Internecie oraz powszechności ich użycia przez rodziców.

\section{Metodologia}

Artykuł stanowi próbę zasygnalizowania, że ta codzienność, w sposób znaczący, wpłynęła na formę sprawowania opieki rodzicielskiej. Co więcej, może ona nosić znamiona krzywdzenia dziecka. Celem głównym pracy jest próba określenia poziomu zagrożenia i skutków oraz czynników i komponentów wpływających na modne zjawisko troll parentingu.

W artykule zostaną podniesione fundamentalne problemy: czy troll parenting może krzywdzić dzieci, czy dobra intencja rodzica może złagodzić skutki ewentualnego krzywdzenia. Podjęta zostanie również próba określenia bezpiecznych granic publikacji zdjęć własnego dziecka w Internecie. Analizując zjawisko troll parentigu i jego rosnący zasięg, warto zadać sobie pytanie, czy pomimo braku regulacji prawnych i niezależnie od dobrych intencji rodzica troll parenting może stanowić formę krzywdzenia dziecka.

Na potrzeby tego opracowania przyjęto zakres omawianego zagadnienia troll parentingu, który dotyczy wyłącznie postępowania rodziców niezwiązanego z umyślnym działaniem na niekorzyść dziecka. Mowa będzie zatem o dokonywanej przez rodzica publikacji zdjęcia dziecka, która jest podyktowana poczuciem dumy, radości, potrzeby pochwalenia się rozwojem dziecka lub podzielenia się śmieszną sytuacją z nim w roli głównej.

Analizę oparto na badaniu ankietowym zaprezentowanym w niniejszym artykule. Zostało ono przeprowadzone w okresie od 17.07.2019 r. do 29.07.2019 drogą elektroniczną wśród rodziców korzystających z portali społecznościowych. Uzyskano 47 odpowiedzi, które w tekście wskazano w sposób ilościowy, tj. jako łączną liczbę odpowiedzi udzielonych na dane pytanie. Uczestnicy badania pochodzili głównie z miast: 20 osób z miejscowości powyżej 250 tys. mieszkańców, 7 osób - 101-250 tys. mieszkańców, 3 osoby - 51-100 tys. mieszkańców, 9 osób - do 50 tys. mieszkańców 
oraz 8 osób z obszarów wiejskich. Były to w przeważającej części osoby o wyższym wykształceniu - 43 odpowiedzi i średnim - 4 odpowiedzi. Wśród nich zdecydowaną większość stanowiły kobiety - 43 głosy, mężczyźni - 4 głosy. Przedział wiekowy badanych to przede wszystkim 31-40 lat (29 odpowiedzi), 21-30 (12 odpowiedzi), 41 i więcej (6 odpowiedzi). Każda z ankietowanych osób jest rodzicem, a wiek najstarszego dziecka nie przekraczał 18 lat. Ankieta zawierała pytania ogólne o znajomość zakresu pojęcia troll parentingu, następnie weryfikowała, czy i w jakim zakresie respondent publikuje zdjęcia lub treści wideo z udziałem własnego dziecka oraz czy i jak często śledzi podobne treści w Internecie. Kolejne pytania dotyczyły definicji krzywdzenia dziecka oraz poglądu na temat tego, czy troll parenting może przybierać formę krzywdzenia dziecka. Badanie miało na celu weryfikację poziomu świadomości problemu wśród rodziców oraz poznanie ich opinii odnoszących się do omawianego zjawiska.

\section{Analiza badań}

Rodzic - to z zasady osoba rozsądna, podejmująca działania mające na celu dobro dziecka, ktoś, kto jest dumny ze swojej pociechy. Ten rodzic z różną częstotliwością publikuje zdjęcia swojego dziecka w Internecie. Czy jego działania, pomimo czystych intencji, są dla dziecka dobre? Czy każdy kolejny post może doprowadzić do emocjonalnego skrzywdzenia dziecka? Czy możemy mówić o presji na modne macierzyństwo prowadzone w świecie wirtualnym?

Publikacje treści z dziećmi w roli głównej są dziś modną sferą macierzyństwa, która w pewnym stopniu krzywdzi dziecko i wypływa negatywnie na jego późniejsze postrzeganie przez rówieśników, pracodawców, osoby trzecie. W skrajnych przypadkach może ona stanowić narzędzie przemocy rówieśnicznej lub źródło pozyskania danych dla pedofila.

W polskim systemie prawnym brak jest uregulowań dotyczących stricte troll parentingu, czy też ochrony dziecka przed działaniami rodzica w Internecie. Posiłkować się należy art. 81 ust. 1 ustawy o prawie autorskim i prawach pokrewnych, który reguluje ochronę wizerunku. Przepis ten wydaje się jednak być niewystarczający, gdyż publikacja zdjęcia wymaga w omawianej sytuacji zgody rodziców. O taką jednak trudno wnioskować, ponieważ to rodzic sam podejmuje decyzję o dodaniu posta. Czy sam sobie udzielił takiej zgody - jest to niemożliwe do oceny.

Omawiając zjawisko troll parentingu, warto uświadomić sobie skalę tego problemu, z pozoru błahego i nieistotnego, będącego bardziej „modą”, w której prawie każdy chętnie uczestniczy, a w rzeczywistości jego konsekwencje mogą doprowadzić do zaburzeń rozwoju dziecka. Bez wątpienia należy stwierdzić, że zjawisko to jest powszechne, co tylko utwierdza w przekonaniu, że temat jest niezwykle ważny.

Troll parenting - trend, który wydaje się, że na skutek połączenia globalnego dostępu do Internetu z prostotą użytkowania smartfonów i innych urządzeń, zdecydowanie przybrał na sile. Wśród badanych 32 respondentów nie znało wcześniej pojęcia 
troll parentingu, choć 30 osób przynało się do bycia uczestnikiem tego rodzaju praktyk. Niemalże każdego dnia widzimy materiały, które prezentują dziecko ubrudzone jedzeniem, dziecko wystylizowane tak, że przypomina dorosłą diwę czy gangstera, dziecko bawiące się przedmiotami dla dorosłych, a także maluchy siedzące na nocnikach, leżące w wannie oraz biegające nago po ogrodzie, plaży lub pokoju. Co więcej, publikowane są również treści wideo utrwalające sytuacje dla dziecka trudne, pełne negatywnych emocji, które w odczuciu dorosłego dają powód do śmiechu. Mowa o dzieciach płaczących, zmęczonych, przeklinających, odgrywających niewłaściwe dla nich role oraz o incydentach uchwytujących pomyłkę dziecka lub upadek. W troll parentingu najważniejszy element stanowi chwilowe „zawładnięcie” Internetem, czyli zdobycie maksymalnie dużej liczby wyświetleń, polubień - ogólnikowo mówiąc, skupienia na sobie uwagi bliskich znajomych, rodziny, a także każdej innej osoby korzystającej z sieci.

Rodzicom biorącym udział w troll parentingu towarzyszą dwa główne cele. Pierwszy to właśnie zdobycie popularności konta użytkownika, a drugi to pochwalenie się swoją pociechą. Oba cele mają charakter chwilowy, gdyż maksymalizacja publikowanych treści wpływa znacznie na obniżenie czasu trwania „sukcesu” posta. Zabawa jest bardzo prosta, zwłaszcza po uruchomieniu przez portale możliwości dodawania 24-godzinnych relacji, które po tym czasie teoretycznie znikają z aplikacji. W tej sytuacji odczucie zagrożenia prawdopodobnie niweluje się, a rodzice są bardziej skorzy do udostępniania materiałów. Mogą się prześcigać w kolejnych publikacjach, i tak tworzy się ich masa, czas, jaki inni użytkownicy mogą poświęcić na ich poszczególne obejrzenie, maleje, a wielość treści może sprawić, że nie każdy potencjalny odbiorca będzie w stanie dotrzeć do danego zdjęcia, filmu.

Zjawisko troll parentigu należałoby podzielić na dwie kategorie, mając na uwadze kryteria: zasięgu i częstotliwości. Z punktu widzenia zasięgu można wyróżnić działania o charakterze publicznym i prywatnym. 4 respondentów posiadało konto o charakterze publicznym, a 38 o charakterze prywatnym. Istniała również grupa 5 badanych, która miała różne ustawienia kont, w zleżności od portalu. Wszystko zależy od ustawień konta i widoczności postów w portalu. Te ustawienia wraz z odpowiednim opisem publikowanej treści odzwierciedlają stopień dotarcia do odbiorców. Przykładowo, dodanie zdjęcia na portalu i udostępnienie go w wersji „publiczne” z opisem \#mamaicórka powoduje, że każda osoba zainteresowana tym terminem może do tego zdjęcia dotrzeć bardzo szybko, a nawet odwrotnie, gdyż samo zdjęcie może „odnaleźć” konkretną osobę dzięki zapamiętanej obserwacji danego hashtaga. Zatem jeśli rodzice chcą zdobyć „internetową sławę”, to oczywiście nie może być mowy o dostępach prywatnych, które w sposób znaczący ograniczają liczbę odbiorców do tylko tych użytkowników, którym daliśmy zgodę na obserwację.

Drugim kryterium jest częstotliwość publikacji. W tym kontekście możemy mówić o sporadycznym dodawaniu postów, załóżmy, że rzadziej niż raz w miesiącu, częstym, czyli mniej więcej raz na tydzień, lub nagminnym czy też codziennym. Tę 
ostatnią grupę szeroko zasilają osoby publiczne oraz pretendujące do miana zawodowych blogerów, którzy zdobywają sławę jako rodzice i za pomocą wizerunku swoich dzieci często promują różnego rodzaju produkty. W takich wypadkach możemy mówić o kilkunastu udostępnieniach dziennie, co często stanowi tak naprawdę całkowitą relację czynności dzieci z danego dnia. Większość, aż 39 respondentów przyznało się do publikacji zdjęć rzadziej niż raz w miesiącu, 5 - raz w miesiącu oraz 2 - raz w tygodniu. Tylko jedna osoba wśród badanych zadeklarowała, że publikuje treści każdego dnia. Jednak ponad połowa (aż 28 udzielonych odpowiedzi) stwierdziła, że obserwuje podobne treści codziennie.

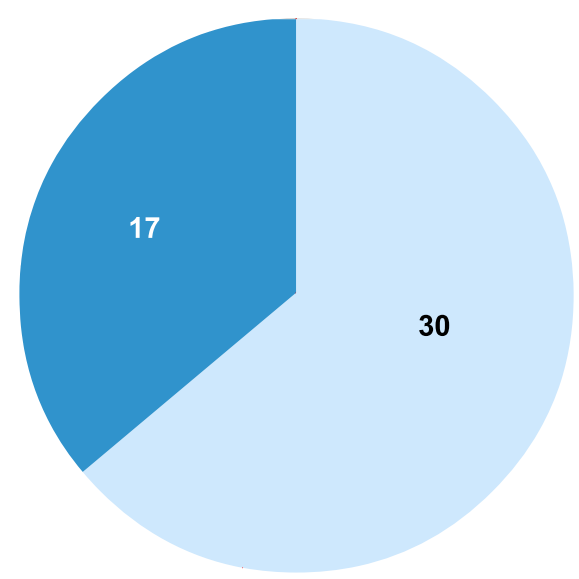

Rysunek 1. Czy publikuje Pan/Pani na portalach społecznościowych zdjęcia lub filmy z udziałem własnego dziecka?
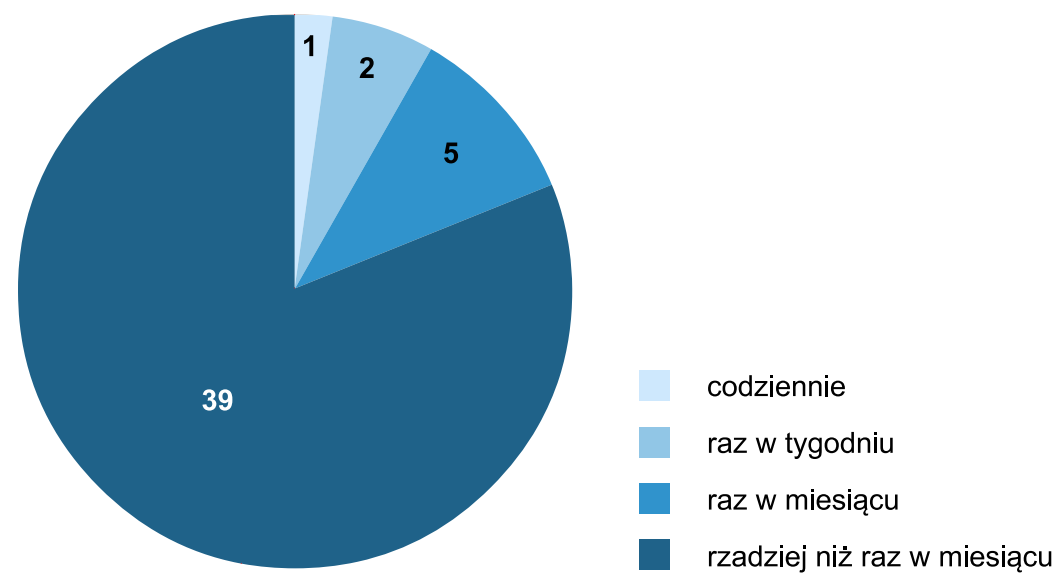

Rysunek 2. Jak często publikuje Pan/Pani na portalach społecznościowych zdjęcia lub filmy z udziałem własnego dziecka? 

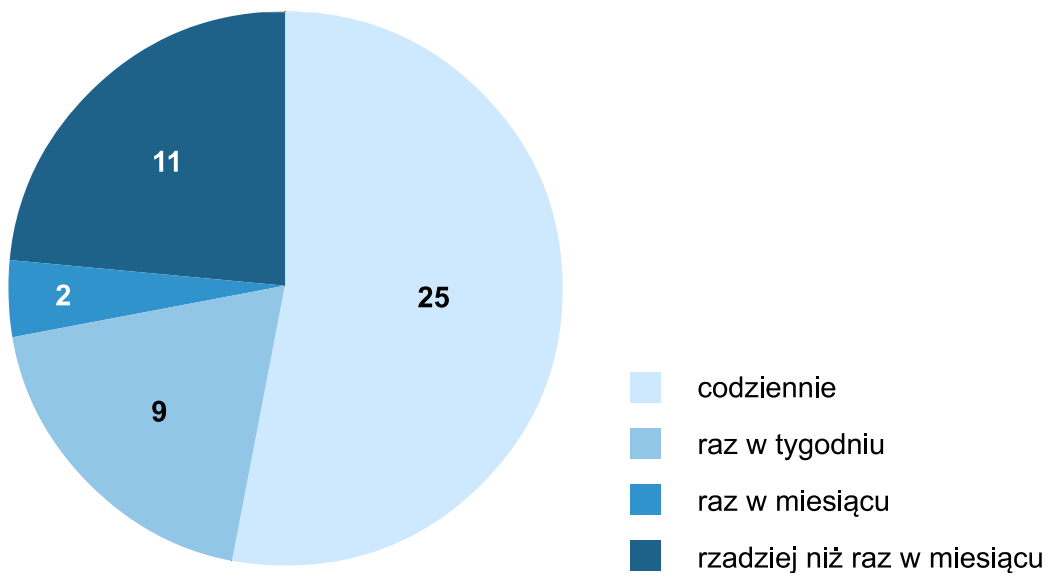

Rysunek 3. Jak często ogląda Pan/Pani treści dodawane przez innych rodziców?

Zjawisko troll parentigu jest silnie rozwijającym się zjawiskiem społecznym, które nie jest uregulowane prawnie. Jednak sama czynność polegająca na publikacji wizerunku, a dokładnie jej szczególna ochrona, jest uregulowana w art. 81 ust. 1 ustawy o prawie autorskim i prawach pokrewnych ${ }^{1}$. Zgodnie z tym artykułem rozpowszechnianie wizerunku wymaga zezwolenia osoby na nim przedstawionej, a w analizowanym przypadku będzie to odpowiednio zgoda udzielona przez jednego z rodziców sprawującego władzę rodzicielską. Dzieci w świetle prawa nie dysponują pełną zdolnością do czynności prawnych, a co się z tym wiąże - nie mogą same rozporządzać przysługującymi im prawami. Dlatego ustawodawca rodzicom lub innym opiekunom prawnym powierzył obowiązek dbania i działania w oparciu o ich dobro do momentu osiągnięcia przez podopiecznych pełnoletniości.

W sytuacji, gdy publikacja zdjęcia czy filmu z udziałem dziecka bez zgody jednego z rodziców trafi na wokandę, sąd rozważa, czy takie uwiecznienie wizerunku małoletniego może uwłaczać jego godności lub istnieje możliwość popełnienia przestępstwa lub uzyskania korzyści majątkowych kosztem dziecka. Sąd również sprawdza, czy dana treść nie podlega jednemu z wyjątków od konieczności uzyskania zgody na wykorzystanie wizerunku dziecka, tj. gdy stanowi on jedynie część większego zgromadzenia lub krajobrazu, bądź za publikację wizerunku pobrane zostało wynagrodzenie. Warto podkreślić, że zdjęcia czy filmy publikowane przez rodziców, w ramach omawianego pojęcia troll parentingu, z reguły nie mają charakteru zarobkowego, który w praktyce ochrona wizerunku dziecka ma zminimalizować.

Zgodnie z art. 49 k.p.k. ${ }^{2}$, pokrzywdzonym jest osoba fizyczna lub prawna albo instytucja, której dobro prawne zostało bezpośrednio naruszone lub zagrożone przez

${ }^{1}$ Ustawa z dnia 4 lutego 1994 r. o prawie autorskim i prawach pokrewnych (Dz.U. z 1994 r. Nr 24, poz. 83 z późn. zm.).

${ }^{2}$ Ustawa z dnia 6 czerwca 1997 r. - Kodeks postępowania karnego (Dz.U. z 1997 r. Nr 89, poz. 555 z późn. zm.). 
przestępstwo. Mowa o naruszeniu lub zagrożeniu indywidualnego dobra prawnego, bez brania pod uwagę zależności, czy stanowiło to zasadniczy, czy uboczny przedmiot ochrony. Takie zindywidualizowanie dobra prawnego przede wszystkim ogranicza krąg podmiotów uprawnionych jako strona procesowa, ale również konkretyzuje pokrzywdzonego ${ }^{3}$. Warunkiem zaistnienia pokrzywdzenia jest fakt, by dobro prawne zostało naruszone lub zagrożone bezpośrednio wskutek przestępstwa. Zgodnie z postanowieniem Sądu Najwyższego, pokrzywdzonym jest tylko ten podmiot, którego dobro prawne zostało naruszone wprost działaniem przestępczym ${ }^{4}$. Definicja ta dotyczy pokrzywdzonego w znaczeniu materialnym. Natomiast k.p.k. przewiduje również pokrzywdzonego w znaczeniu formalnym, nadając mu status pokrzywdzonego. Przykładowo takim podmiotem jest Zakład Ubezpieczeń Społecznych. Jednak aby była mowa o skrzywdzeniu, według J. Czapskiej, nie musi dojść do przestępstwa. Zgodnie z jej definicją, pokrzywdzonym jest osoba, która odczuwa stratę lub krzywdę, w wyniku obiektywnego poszkodowania przynależnych jej dóbr prawnych, niekoniecznie wskutek przestępstwa ${ }^{5}$. Zatem dziecko, które doznało krzywdy niezwiązanej z działalnością przestępczą, może stanowić osobę pokrzywdzoną, choć bardziej w rozumieniu nauk pozaprawnych (psychologii i pedagogiki) niż prawa karnego.

Krzywdzenie dziecka to stosowanie wobec niego przemocy. Sam termin „przemoc” określany jest różnorodnie. Zdaniem G. Pilz, „Przemoc to wyraz o 7 literach i 1000 nieporozumień"6. Jednak przemoc to znacznie więcej. Według amerykańskiego Centrum Pomocy Dzieciom Krzywdzonym i Zaniedbywanym, przemoc to fizyczne lub umysłowe działanie na szkodę, wykorzystywanie seksualne, zaniedbywanie lub maltretowanie dziecka w wieku poniżej 18. roku życia przez osobę odpowiedzialną za jego rozwój, oraz wszystkie działania, które noszą znamiona zagrożenia dla jego rozwoju ${ }^{7}$. Krzywdzenie dzieci, jak twierdzi D. Gil, to każde działanie lub bezczynność jednostki, instytucji lub społeczeństwa jako całości i każdy rezultat takiego działania lub bezczynności, który deprywuje równe prawa i swobody dzieci i/lub zakłóca ich optymalny rozwój ${ }^{8}$. Przemoc stanowi również każdy zamach na swobody jednostki, w wyniku którego dochodzi do uszczerbku na ciele lub w zakresie funkcji psychicznych $^{9}$. J. Rudniański postrzega przemoc jako relację zachodzącą między jednym

3 K. Dudka, H. Paluszkiewicz, Postępowanie karne, Wolters Kluwer Polska, Warszawa 2018, s. 91.

${ }^{4}$ Postanowienie SN z 25.03.2010 r., IV KK 316/09, OSNwSK 2010/1, poz. 645.

${ }_{5}$ M. Szymańczak, Pojęcie krzywdzenia dzieci, „Niebieska Linia” 1999, nr 1, https://www.niebieskalinia.pl/pismo/wydania/dostepne-artykuly/4409-pojecie-krzywdzenia-dzieci [dostęp: 27.07.2019].

${ }^{6}$ W. Sofsky, Traktat o przemocy, przeł. M. Adamski, Wydawnictwo Dolnośląskie, Wrocław 1999.

${ }^{7}$ K. Kmiecik-Baran, Przemoc wobec dzieci - diagnoza i interwencja, [w:] J. Papież, A. Płukis (red.), Przemoc dzieci i młodzieży w perspektywie polskiej transformacji ustrojowej, Wydawnictwo Adam Marszałek, Toruń 1998.

${ }^{8}$ D. Gil, Violence against children, Harvard University Press, Cambridge 1970.

${ }^{9}$ K. Kmiecik-Baran, dz. cyt. 
człowiekiem a drugim ${ }^{10}$ (w tym wypadku rodzic-dziecko). W omawianym zjawisku troll parentingu należy przyjąć uniwersalne definicje przemocy, które uznają szeroki zakres zachowań rozumiany jako działania przemocowe. W ich ramach posiadamy najczęściej odwołania do zagrożeń rozwoju, praw i swobód oraz do łamania podmiotowości jednostki. Sprawcami są przede wszystkim rodzice i opiekunowie ${ }^{11}$. Istotnym elementem przemocy wobec dziecka jest również intencja, w tym wypadku rodzica. Dziecko może zostać skrzywdzone, nawet jeśli nie taka była intencja osoby, która tego skrzywdzenia dokonała. Analizowanie przemocy na tej płaszczyźnie kieruje do przyjęcia formy błędu wychowawczego. Mowa o koncepcji A. Guryckiej, która mianem błędu wychowawczego określa zachowania rodziców, opiekunów, które stanowią czynnik lub realną groźbę powstania szkodliwych, tymczasowych lub długotrwałych skutków dla rozwoju i funkcjonowania dziecka ${ }^{12}$. Takim błędem jest działanie rodzica, które nie ma charakteru intencjonalnego, a jego podjęcie nie jest związane z umyślnym wyrządzeniem szkody dziecku. Można zatem powiedzieć, że rodzic jest całkowicie nieświadomy krzywdy wyrządzonej dziecku. Przykładowo, nadopiekuńczość czy zbyt wysokie oczekiwania mogą stanowić krzywdzenie dziecka, a nie są intencjonalne ${ }^{13}$.

Wyróżniamy różne rodzaje przemocy: krzywdzenie emocjonalne, fizyczne, seksualne lub zaniedbanie. Choć do niedawna często w opinii publicznej krzywdzenie dziecka oznaczało wyłącznie jego bicie, to pogląd ten wskutek wielu kampanii edukacyjnych uległ już zmianie. Respondenci na pytanie wielokrotnego wyboru: „Czym według Pana/i jest krzywdzenie dziecka?”, odpowiedzieli, że jest to przede wszystkim krzyk, karanie, upokarzanie i porzucenie. Niemniej jednak widoczny staje się również aspekt nadmiernej opiekuńczości rodziców i wiążącej się z tym późniejszej ułomności dziecka w życiu codziennym jako przejaw krzywdzenia.

${ }^{10}$ J. Rudniański, Klasyfikacja, źródła i ocena przemocy w stosunkach międzyludzkich. Zarys ogólny, [w:] B. Hołyst (red.), Przemoc w życiu codziennym, Cinderella Books, Warszawa 1997.

${ }^{11} \mathrm{~J}$. Brągiel, Zrozumieć dziecko skrzywdzone, Wydawnictwo Uniwersytetu Opolskiego, Opole 1996.

12 A. Gurycka, Bład w wychowaniu, Wydawnictwa Szkolne i Pedagogiczne, Warszawa 1990.

${ }_{13}$ D. Iwaniec, Emocjonalne krzywdzenie dzieci, „Dziecko Krzywdzone” 2012, nr 2. 


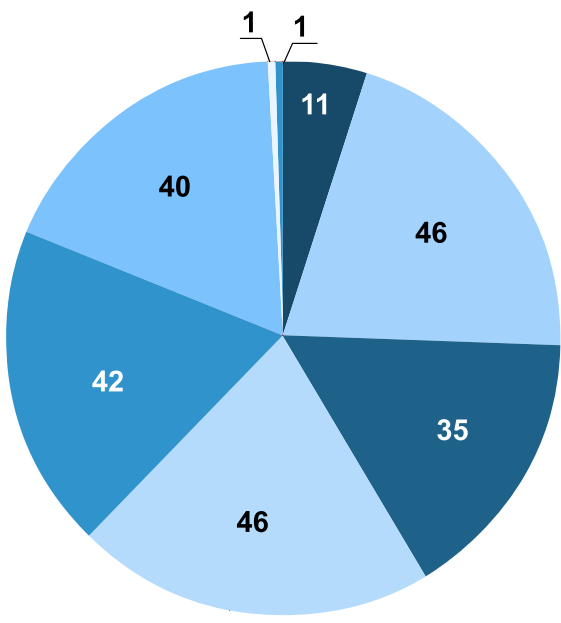

wyłącznie bicie

krzyczenie i bicie

nadmierna nadopiekuńczość

poniżanie i upokarzanie nadmierne karanie

porzucenie

przemoc psychiczna i seksualna

troll parenting

Rysunek 4. Czym według Pana/Pani jest krzywdzenie dziecka?

W omawianym zagadnieniu troll parentingu należy przede wszystkim zwrócić uwagę na emocjonalne krzywdzenie dziecka. Problem ten jest bardzo często marginalizowany z powodu braku określonych granic działania rodzica. Przemoc emocjonalna to każde działanie rodzica, opiekuna, które nie zawiera aktów przemocy fizycznej, a prowadzi lub może prowadzić do zaburzeń prawidłowego rozwoju dziecka, w tym emocjonalnego, osobowościowego obniżenia poczucia własnej wartości, stanów lękowych i nerwicy. Przejawia się głównie krzykiem, obrażaniem dziecka, poniżaniem go, szantażem, straszeniem i emocjonalnym odrzuceniem ${ }^{14}$. Przemoc emocjonalna jest często określana mianem werbalnej formy agresji lub wrogości wobec dziecka. Problem z określeniem tego zjawiska jest spowodowany nie tylko jego zakresem, ale również wykrywalnością. Trudno zaobserwować, czy dane działanie rodzica nosi znamiona przemocy emocjonalnej ${ }^{15}$. Krzywdzenie emocjonalne zostało określone jako „ukryta forma krzywdzenia” lub „nieuchwytne przestępstwo” właśnie z uwagi na trudność identyfikacji wprost danego zachowania jako postaci krzywdzenia, ponieważ nie zostawia ono fizycznych śladów, np. blizn, siniaków ${ }^{16}$.

${ }^{14}$ M. Sajkowska, Wprowadzenie do problematyki krzywdzenia dziecka, „Niebieska Linia” 2001, nr 1 .

${ }_{15}$ B. Nakoneczna, Dziecko jako ofiara przemocy w rodzinie, [w:] B. Hołysz (red.), Ochrona dziecka. Teoria i praktyka, Wydawnictwo CSP, Legionowo 2005.

${ }^{16}$ D. Iwaniec, dz. cyt. 
Wskutek troll parentingu rodzic może świadomie lub nieświdomienie doprowadzić do emocjonalnego porzywdzenia dziecka. 39 badanych uważało, że publikacja treści z udziałem dziecka może prowadzić do krzywdy dziecka, z czego 2 stwierdziło, że zachodzi to tylko w sytuacji, gdy dana treść ukazuje nagość dziecka.
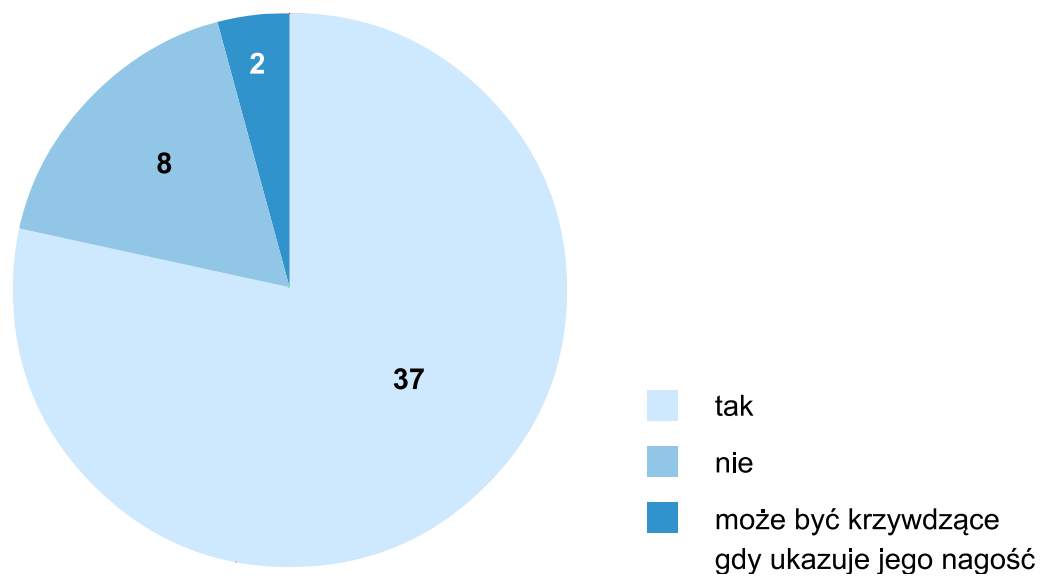

Rysunek 5. Czy uważa Pan/Pani, że publikowanie zdjęć dziecka może stanowić formę krzywdzenia?

Według respondentów, ta krzywda może nastąpić tylko wtedy, gdy treści będą zawierały określony charakter. Wśród najczęściej udzielanych odpowiedzi na pytanie otwarte: „W jaki sposób według Pana/i publikacja zdjęć czy filmów może stanowić formę krzywdzenia dziecka?”, należy wyróżnić:

- ośmieszenie, upokorzenie - powoduje obniżenie własnej wartości,

- materializm - pokazywane dobra materialne mogą zaburzyć bezpieczeństwo dziecka,

- nieposzanowanie prywatności - brak zgody dziecka,

- uwiecznienie czynności fizjologicznych oraz emocji dziecka, zwłaszcza negatywnych,

- przedstawianie dziecka w negatywnym świetle, tj. niekorzystnie wyglądające, brudne - narażenie na hejt.

Każde upokorzenie dziecka jest formą przemocy emocjonalnej, ale nie każde może prowadzić do zaburzeń rozwoju czy zachowania ${ }^{17}$. Jak wspomniano wyżej, trudno zaobserwować, czy dane zachowania są skutkiem krzywdzenia emocjonalnego oraz czy omawiane działania rodzica przekroczyły tę cienką granicę i stanowią przemoc. Może się bowiem okazać, że skutki troll parentingu będą widoczne dopiero po wielu latach. Od czasu, kiedy Internet dał możliwości powstania i rozwoju troll parentingu, wiele dzieci będących bohaterami omawianego zjawiska już dorosło. Zaczynają być widoczne pierwsze próby egzekwowania przez nie własnych praw. 18-letnia

\footnotetext{
${ }^{17}$ B. Nakoneczna, dz. cyt.
} 
Austriaczka pozwała rodziców za publikację bez jej zgody zdjęć z dzieciństwa, które w jej odczuciu są krępujące. W Portugalii sąd zakazał rodzicom 12-letniej dziewczynki publikacji jej zdjęć w Internecie. W uzasadnieniu orzeczenia wskazano na ryzyko ataku na tle seksualnym oraz obowiązek rodziców do ochrony wizerunku własnego dziecka. Ponadto istnieje związek pomiędzy zaginięciami dzieci a korzystaniem przez nie z portali społecznościowych. Z rosnącym problemem zaginięć zmaga się Portugalia i Francja. We tym drugim kraju postanowiono podnieść stopień ochrony wizerunku dzieci przez wprowadzenie kary grzywny lub kary pozbawienia wolności do roku za nierozważne i nieodpowiedzialne publikowanie przez rodziców zdjęć dzieci bez ich zgody. Choć w Polsce nie mamy podobnych rozwiązań normatywnych, to możliwości techniczne, jakie daje Internet, są dokładnie takie same. Rosnący problem szeroko rozumianego tzw. hejtu i kwestia anonimowości wyrażania swoich poglądów mogą dodatkowo pogłębić problem troll parentingu. Czynność publikowania zdjęcia przez rodzica może skrzywdzić dziecko nie tylko bezpośrednio, ale również pośrednio przez narażenie go na ośmieszenie i obelgi.

Pierwszy wyrok w naszym kraju już zapadł, i choć jest to jednostkowa sytuacja, to stan faktyczny, którego sprawa dotyczyła, już nią nie jest. Ojciec dwuletniego dziecka podczas sprawowania nad nim opieki i w trakcie zabawy polegającej na bieganiu malucha po domu bez ubrania, tylko w bursztynowym naszyjniku na szyi, postanowił zrobić mu zdjęcie. Na tym się niestety nie skończyło, bo zdjęcie zostało dodatkowo zainscenizowane. Chłopiec, siedząc na umywalce i trzymając jedną ręką swoje przyrodzenie, w drugiej ręce miał butelkę po piwie. Tak uwieczniony portret został wstawiony na jeden z portali społecznościowych, oczywiście jako przejaw dumy ojca z syna. Matka dziecka, nie wyraziła zgody na taką publikację i zażądała jej usunięcia, co nie odniosło żadnego skutku. Sprawa trafiła na wokandę, gdzie w pierwszej instancji sąd nie przychylił się do wniosku prokuratora o skazanie ojca na podstawie art. 191a k.k. Jednak sąd odwoławczy ocenił działanie polegające na publikacji tego typu zdjęcia jako wychodzące poza zakres zwykłego zarządu i stwierdził, że publikacja byłaby możliwa, jeśli zgodę wyraziliby oboje rodzice. Ojciec został skazany na 9 miesięcy ograniczenia wolności, a wskutek apelacji karę zmniejszono do 3 miesięcy. Jak się okazało, tata argumentował swoje działanie jako chęć pokazania sztuki fotografii artystycznej, a matka dziecka wcześniej miała podobny incydent i również opublikowała nagie zdjęcie dziecka, tylko w innych, bo naturalnych okolicznościach - na plaży. Ta sytuacja pokazuje nam, że sam fakt publikacji nie jest wyjątkową i sporadycznie dokonywaną czynnością. Ma ona miejsce w wielu domach. Tylko ocena jej skutków dla dziecka, bo w omawianej sytuacji był to konflikt rodziców, który natychmiast wybuchł i wywarł skutek prawny, jest niezwykle trudna i może nie być rozpoznana.

Troll parenting dotyka też innych problemów. Przykładowo, kolejną negatywną stroną tego zjawiska jest pedofilia, choć jest to problem najczęściej będący poza świadomością rodziców. Publikowane treści mogą wywołać zainteresowanie na tle seksualnym. Według badań przeprowadzonych przez Kidprotect.pl oraz Onet.pl, 
18 tys. razy w ciągu miesiąca internauci wyszukiwali treści związanych z pornografią dziecięcą i pedofilią ${ }^{18}$.

Istnieje również inne ryzyko związane bezpośrednio z troll parentingiem. Zwracają na nie uwagę autorzy kompendium Bezpieczeństwo dzieci online Polskiego Centrum Programu Safer Internet, według których publikacje zdjęć dziecka bez jego zgody tworzą w sieci swoisty cyfrowy życiorys dziecka, który zostaje porzucony po fali popularności, ale żyje dalej własnym życiem jeszcze długo po publikacji, pomimo usunięcia fotografii. Na tej podstawie mogą być budowane profile psychologiczne, wykorzystywane np. przez uczelnie i pracodawców. Dochodzi do tego problem z łatwością pobierania zdjęć i dysponowania nimi bez ograniczeń. Co więcej, zdjęcia te mogą trafić w ręce rówieśników i stanowić narzędzie do cyberprzemocy.

\section{Podsumowanie i wnioski z badań}

Postawione w artykule problemy badawcze i ich analiza dowodzą, że pojęcie troll parentingu, choć nie jest znane, to jest powszechnym zjawiskiem, które może prowadzić do krzywdzenia dziecka na tle emocjonalnym. Tego rodzaju krzywdzenie, często nieświadomie wyrządzone dziecku przez jego rodziców, charakteryzuje się niskim poziomem wykrywalności i często jest marginalizowane, a reakcja dziecka na nie odbierana jako jego bunt. Ponieważ jest trudne do wykrycia i oceny, jego skutki moga być bardzo negatywne. Publikacja zdjęć dziecka w Internecie niesie ze sobą dużo zagrożeń, poczynając od narażenia na wyśmianie, a kończąc na pedofilii. Skutkiem takiego krzywdzenia są zmiany relacji rodzinnych, niestabilność psychiczna dziecka, a także brak pewności w dorosłym życiu. Każda forma ośmieszenia, upokorzenia czy prezentowania treści przez dziecko niechcianej zdecydowanie może przynieść negatywne skutki przekładające się na jego dorosłe kroki. Udowodniono również, że dobra intencja rodzica nie ma wpływu na rozmiar potencjalnej krzywdy. Najczęściej nieświadomie bierzemy udział w zjawisku, które może przyczynić się do krzywdzenia dzieci nie tylko własnych, ale również obcych przez bierne oglądanie i udostępnianie treści dostępnych na portalach społecznościowych. Ta w dużej mierze zależna jest od środowiska i społeczności Internetowej. W artykule wykazano również negatywny wpływ na zjawisko braku regulacji prawnych, które wydają się pogłębiać problem przez bagatelizowanie samej czynności i możliwych jej skutków. Brak uregulowań prawnych sprawia, że każdy rodzic, umyślnie, czy też nie, ma pełne prawo robić to, co mu się podoba, nie widząc drugiej strony medalu i nie patrząc na skutki własnych

${ }_{18}$ Zainteresowanie internetowa pedofilia $w$ Polsce, badanie Kidprotect.pl, Onet.pl i Rzecznika Praw Dziecka, 2004. Badania opublikowane w ramach kampani „Mądrzy Rodzice”. Ogólnopolskie badanie kompetencji wychowawczych rodziców przeprowadziła firma MillwardBrown SMG/KRC. Raport z badań, Fundacja Kidprotect.pl, http://www.madrzy-rodzice.pl/pl/o-programie/badania/ [dostęp: 14.05.2016]. 
działań. Podczas analizy podjęto również próbę określenia granic bezpiecznej publikacji, na którą wpływ mają rozwaga i umiarkowanie rodziców, a zatem czynniki niepewne i niestanowiące ochrony dziecka.

Temat publikowania zdjęć dzieci w Internecie dzieli zdania rodziców. Dla jednych to przekroczenie granic władzy rodzicielskiej i naruszenie prywatności niczego nieświadomych dzieci i forma upokorzenia swojej pociechy, dla innych - naturalne prawo rodziców do dysponowania wizerunkiem własnego dziecka. Troll parenting to przede wszystkim zły nawyk rodzica, który może, ale nie musi skutkować skrzywdzeniem dziecka. Warto zwrócić uwagę na formę i charakter publikowanych materiałów oraz na to, jakie treści obserwujemy, żeby sztucznie nie podbijać tego trendu. Warto zastosować zasadę złotego środka: jeśli publikować, to niewiele, mądrze, mając na uwadze zarówno dobro i godność dziecka, jak i odpowiednie zabezpieczenia, które ochronią jego cenny wizerunek przed negatywnymi konsekwencjami nierozważnej publikacji. Pomyśl, zanim wrzucisz coś do sieci.

\section{Bibliografia}

Brągiel J., Zrozumieć dziecko skrzywdzone, Wydawnictwo Uniwersytetu Opolskiego, Opole 1996.

Dudka K., Paluszkiewicz H., Postępowanie karne, Wolters Kluwer Polska, Warszawa 2018. Gil D., Violence against children, Harvard University Press, Cambridge 1970.

Gurycka A., Bład w wychowaniu, Wydawnictwa Szkolne i Pedagogiczne, Warszawa 1990.

Iwaniec D., Emocjonalne krzywdzenie dzieci, „Dziecko Krzywdzone” 2012, nr 2.

Kmiecik-Baran K., Przemoc wobec dzieci - diagnoza i interwencja, [w:] J. Papież, A. Płukis (red.), Przemoc dzieci i młodzieży w perspektywie polskiej transformacji ustrojowej, Wydawnictwo Adam Marszałek, Toruń 1998.

Nakoneczna B., Dziecko jako ofiara przemocy w rodzinie, [w:] B. Hołysz (red.), Ochrona dziecka. Teoria i praktyka, Wydawnictwo CSP, Legionowo 2005.

Rudniański J., Klasyfikacja, źródła i ocena przemocy w stosunkach międzyludzkich. Zarys ogólny, [w:] B. Hołyst (red.), Przemoc w życiu codziennym, Cinderella Books, Warszawa 1997.

Sajkowska M., Wprowadzenie do problematyki krzywdzenia dziecka, „Niebieska Linia” 2001, nr 1 .

Sofsky W., Traktat o przemocy, przeł. M. Adamski, Wydawnictwo Dolnośląskie, Wrocław 1999.

Szymańczak M., Pojęcie krzywdzenia dzieci, „Niebieska Linia” 1999, nr 1.

Zainteresowanie internetowa pedofilia $w$ Polsce, badanie Kidprotect.pl i Onet.pl, 2004, http://www.madrzy-rodzice.pl/pl/o-programie/badania/ [dostęp: 14.05.2016]. 


\title{
Akty prawne
}

Ustawa z dnia 4 lutego 1994 o prawie autorskim i prawach pokrewnych (Dz.U. z 1994 r. Nr 24, poz. 83 z późn. zm.).

Ustawa z dnia 6 czerwca 1997 r. - Kodeks postępowania karnego (Dz.U. z 1997 r. Nr 89, poz. 555 z późn. zm.).

\section{Orzeczenia}

Postanowienie SN z 25.03.2010 r., IV KK 316/09, OSNwSK 2010/1, poz. 645.

\section{The phenomenon of "troll parenting" - fashionable motherhood or a form of child abuse?}

\begin{abstract}
Troll parenting is a common phenomenon and an everyday element of life for many families. Excessive publication of photos of a child, without his/her consent, may show signs of emotional violence, even if the parent is completely unaware of this and it is not the parent's intention to harm his/her own child. Posting photos of a child on social networks also results in exposure to ridicule, humiliation, cyber violence, hate and even a potential sexual assault. This article analyzes the issues of troll parenting, potential threats, and presents the level of awareness and attitude of parents who are responsible for this phenomenon.
\end{abstract}

Keywords: troll parenting, child abuse, emotional violence

About the author: Klaudia Smulnik-Barska - a student at the University of Gdańsk, preparing academic work in the field of educational and physical discipline and the associated penal consequences. 
Aneta Jegier* (iD https://orcid.org/0000-0003-2492-4876

Akademia Pedagogiki Specjalnej im. Marii Grzegorzewskiej w Warszawie

https://doi.org/10.25312/2083-2923.17/2020_04aj

\title{
Opieka, wychowanie, edukacja w realiach polskich żłobków publicznych
}

\begin{abstract}
Streszczenie: Praca z małym dzieckiem jest trudna, ale może dostarczać dużo satysfakcji. W grupach żłobkowych nacisk położony jest na bezpieczeństwo podopiecznych, kształtowanie rozwoju czynności samoobsługowych, jak również wzbudzenie w dzieciach chęci poznawania świata. Współcześni rodzice widzą ogromne korzyści z uczestniczenia ich dziecka w życiu żłobkowym. Niniejszy artykuł to analiza możliwości kształtowania i wspierania rozwoju dziecka, jakie oferuje żłobek. W publikacji korzystano z teoretycznych podstaw psychologii rozwojowej i pedagogiki małego dziecka, uregulowań prawnych odnoszących się do funkcjonowania żłobków, czyli tzw. ustawy żłobkowej, oraz własnego doświadczenia, wynikającego z codziennej obserwacji pracy z małymi dziećmi w publicznych warszawskich żłobkach. W artykule znajdują się zarówno treści opisujące uregulowania prawne, jak również przykłady rzeczywistych oddziaływań opiekuńczych, wychowawczych i edukacyjnych, jakie mają miejsce na terenie żłobka.
\end{abstract}

Słowa kluczowe: opieka, wychowanie, edukacja małego dziecka, żłobek

\section{Wprowadzenie}

W dzisiejszych czasach normą jest praca zawodowa obojga młodych rodziców i model rodziny dwupokoleniowej. Bardzo często dziadkowie jeszcze są aktywni zawodowo lub zwyczajnie chcą odpocząć czy zadbać o swoje zdrowie. Rodzice, aby zapewnić swoim dzieciom w ciągu dnia opiekę, wybierają więc żłobek, tym bardziej że

* Aneta Jegier - doktor nauk humanistycznych, adiunkt w Akademii Pedagogiki Specjalnej im. Marii Grzegorzewskiej w Warszawie, w Katedrze Pedagogiki Małego Dziecka. Od trzech lat pełni funkcję kierownika żłobka publicznego w Warszawie. Prezes Stowarzyszenia na rzecz Wspomagania Rozwoju Dzieci ze Specjalnymi Potrzebami Edukacyjnymi. Zajmuje się problematyką wychowania i kształcenia dzieci w wieku żłobkowym i przedszkolnym oraz innowacjami pedagogicznymi w obszarze relacji dorosły-dziecko. Autorka książek i artykułów dotyczących wspomagania dzieci w dobrym funkcjonowaniu w domu, żłobku i przedszkolu. 
ten rodzaj placówek publicznych ma bardzo dobrą opinię. Tradycyjnie żłobek był po prostu placówką opiekuńczą. Od dawna nie ogranicza jednak swej funkcji do zapewnienia dziecku bezpiecznego azylu na czas pracy rodziców. Jego rola jest nieporównanie większa: usamodzielnia, socjalizuje, uczy dzieci poznawania siebie, rodziców zaś wdraża do odkrywania możliwości ich dziecka.

Żłobek to pierwszy i bardzo ważny etap budowania wartości kapitału ludzkiego $\mathrm{w}$ instytucjonalnych ramach, poza rodziną. I bardzo istotny moment kształtowania wartości społeczeństwa przyszłości. Chodzi o to, by dziecko już w najwcześniejszym okresie swojego życia uzyskało przywilej impulsów zróżnicowanych, tworzących różne, odmienne perspektywy. Żłobek, poza zapewnieniem dziecku bezpieczeństwa, dostarcza mu możliwie najwyższej jakości bodźce dla jego optymalnego rozwoju.

\section{Ustawa z dnia 4 lutego 2011 r. o opiece nad dziećmi w wieku do lat 3 - jako podstawowy dokument normujący zasady opieki, wychowania i edukacji dzieci w żłobkach}

Żłobek jest instytucją, która działa w umocowaniu prawnym. Podstawowym aktem prawnym jest Ustawa $\mathrm{z}$ dnia 4 lutego $2011 \mathrm{r}$. o opiece nad dziećmi w wieku do lat 3. W niej określone są zasady organizowania i funkcjonowania opieki nad dziećmi, warunki świadczonych usług, kwalifikacje osób sprawujących opiekę, zasady finansowania opieki, nadzór nad warunkami i jakością sprawowanej opieki. Ustawa wskazuje, że w placówce realizowane są funkcje: opiekuńcza, wychowawcza i edukacyjna.

Zgodnie $\mathrm{z}$ ustawą, opieka $\mathrm{w}$ żłobku jest sprawowana nad dziećmi $\mathrm{w}$ wieku od ukończenia 20. tygodnia życia do roku szkolnego, w którym dziecko ukończy 3. rok życia. W uzasadnionych przypadkach, gdy niemożliwe lub utrudnione jest objęcie dziecka wychowaniem przedszkolnym, można pozostawić dziecko w żłobku do 4. roku życia.

Prawo zobowiązuje żłobek do zapewnienia dzieciom opieki w warunkach bytowych zbliżonych do warunków domowych, zmusza do zagwarantowania właściwej opieki pielęgnacyjnej oraz edukacyjnej przez prowadzenie zajęć zabawowych z elementami edukacji, z uwzględnieniem indywidualnych potrzeb dzieci. Wprowadza konieczność prowadzenia zajęć opiekuńczo-wychowawczych i edukacyjnych, uwzględniających rozwój psychomotoryczny dzieci, właściwych do ich wieku (Ustawa $\mathrm{z}$ dnia 4 lutego 2011 r. o opiece nad dziećmi w wieku do lat 3).

Jak wynika z powyższych założeń, personel żłobka ma dbać o wszechstronny rozwój dziecka w atmosferze prawie domowej. Opieka rozumiana jest bowiem jako zapewnienie bezpiecznych warunków przebywania dzieci, posiłków zgodnych z normami żywienia oraz realizacji zajęć $\mathrm{z}$ wykorzystaniem różnych form zabawy w taki sposób, żeby zostały zaspokojone potrzeby dzieci i wykorzystany ich potencjał rozwojowy.

Obowiązująca obecnie ustawa o opiece nad dzieckiem do lat 3 daje rodzicom w żłobkach duże kompetencje. Rada Rodziców może występować do kierującego 
żłobkiem z inicjatywami, wnioskami i opiniami we wszystkich sprawach dotyczących placówki, w szczególności w zakresie prowadzenia zajęć edukacyjnych. Ma prawo opiniować sprawy organizacyjne żłobka. Ma wgląd do dokumentacji dotyczącej spełniania norm żywienia. Może wizytować pomieszczenia żłobka i w razie potrzeby zgłaszać zastrzeżenia. Współpraca osoby kierującej żłobkiem z rodzicami może więc przyczynić się do poprawy jakości pracy i wzbogacenia oferty zajęć edukacyjnych w placówce.

Ustawa określa także wymagania, jakie musi spełniać personel żłobka, jak również wyraźnie określa liczbę dzieci przypadających na jednego opiekuna. Może on sprawować opiekę nad maksymalnie ośmiorgiem dzieci. Zaś w przypadku gdy w grupie znajduje się dziecko niepełnosprawne lub wymagające szczególnej opieki lub takie, które nie ukończyło pierwszego roku życia - maksymalnie nad pięciorgiem. W żłobku, do którego uczęszcza więcej niż dwadzieścioro dzieci, zatrudnia się przynajmniej jedną pielęgniarkę lub położną.

Ustawa zobowiązuje też żłobek do zapewnienia przebywającym w nim dzieciom wyżywienia zgodne z wymaganiami dla danej grupy wiekowej, wynikającymi z aktualnych norm żywienia dla populacji polskiej, opracowywanych przez Instytut Żywności i Żywienia im. prof. dra med. Aleksandra Szczygła w Warszawie.

Prawo określa także warunki lokalowe, jakie powinien spełniać żłobek. Między innymi wymagane jest dysponowanie przynajmniej jednym pomieszczeniem. W placówce musi być możliwość higienicznego spożywania posiłków i zapewnienia miejsca na odpoczynek dla dzieci. Oczywiście, każda placówka musi spełniać określone prawem wymagania lokalowe, sanitarne i przeciwpożarowe. Nadzór nad żłobkami sprawuje wójt, burmistrz lub prezydent miasta właściwy ze względu na prowadzenie żłobka.

\section{Realizacja funkcji opiekuńczej}

Pracownicy są potencjałem placówki zajmującej się opieką nad małym dzieckiem. Trzeba mieć świadomość tego, że każdy dorosły zatrudniony w żłobku to potencjalny model do naśladowania dla podopiecznych. Dlatego istotne jest w przypadku każdego pracownika nie tylko odpowiednie przygotowanie zawodowe i doskonalenie umiejętności, ale także właściwa postawa wobec dzieci, rodziców i współpracowników. Potrzeby dzieci i rodziców są na pierwszym miejscu w żłobkach i jest to zapisane w statucie każdej publicznej placówki. Jak wynika z obserwacji pracy warszawskich żłobków, personel jest dostępny i służy pomocą zarówno w problemach dnia codziennego, jak i trudnościach wychowawczych. Rozwiewa wątpliwości rodziców i wspiera ich w pokonywaniu lęku o dziecko. Istotny jest pełny przekaz informacji o funkcjonowaniu podopiecznych. Personel powinien być otwarty na uczestniczenie rodziców w życiu placówki, budując wzajemne zaufanie. W żłobkach wszyscy wiedzą - zarówno kadra opiekuńcza i pomocnicza, jak i rodzice, że priorytetem jest dobro dziecka. 
To z myślą o najmłodszych należy starać się wypracować jak najwyższą jakość zarządzania i organizacji pracy. Kierownicy monitorują godziny przyprowadzania dzieci i ich odbierania, konsultują decyzje z rodzicami i dostosowują czas pracy placówki do potrzeb rodzin. Kadra ma świadomość, że wychowuje kolejne pokolenie, gdyż taka jest misja żłobków. Pragnie, żeby podopieczni osiągali życiowe sukcesy dzięki umiejętnościom, jakie w tym miejscu nabywają. I dlatego dokłada się starań, żeby dzieci stawały się z każdym dniem bardziej samodzielne, mądre i uważne.

Dużo czasu wharmonogramie dnia zajmują posiłki serwowane dzieciom ${ }^{1}$. Kształtowanie prawidłowych nawyków żywieniowych i zapewnienie składników odżywczych właściwych do prawidłowego rozwoju młodego organizmu jest jednym z priorytetów opieki żłobkowej. Jadłospis w tych placówkach powinien być zgodny z normami żywienia wprowadzonymi przez Instytut Żywności i Żywienia im. prof. dra med. Aleksandra Szczygła w Warszawie (Dz.U. z 2017 r., poz. 1428, art. 22). Żłobki, dbając o prawidłowy rozwój fizyczny dziecka, pełnią też istotną funkcję w zapewnieniu mu właściwej diety, dostosowanej do wieku i uwzględniającej alergie pokarmowe. Personel powinien znać aktualne normy i podstawowe zasady żywienia małych dzieci oraz kształcić się w zakresie edukacji żywieniowej zarówno dzieci, jak i ich rodziców.

W żłobkach obowiązują wytyczne zawarte w Księdze HACCP - Analiza Zagrożeń i Krytycznych Punktów Kontroli. Dokument ten ukazuje prawidłowe funkcjonowanie placówki pod kątem sanitarno-higieniczno-technologicznym, czyli przedstawia działania podejmowane w zakresie higieny, bezpieczeństwa pracy i kontroli placówki w obszarze produkcji gastronomicznej od surowca do gotowej potrawy, z uwzględnieniem higieny transportu wewnętrznego i konsumpcji posiłków.

Opiekunki w żłobku mają kontakt z żywnością, a przygotowywanie posiłków musi być bezpieczne pod względem zdrowotnym. Panie są zobowiązane do noszenia czepków, a nakładanie porcji odbywa się w rozdzielni żywności. Same posiłki powinny być smaczne, kolorowe i pachnące zgodnie z zasadami dietetyki pediatrycznej oraz higieny produkcji żywności.

Żłobek to miejsce, w którym dzieci dostają większość posiłków spożywanych w ciągu dnia, dlatego szczególnie ważne jest prawidłowe sporządzanie jadłospisu, aby był odpowiednio zbilansowany i urozmaicony. Właściwa organizacja posiłków podawanych dziecku zapewnia równomierną podaż energii, a także zapobiega błędom żywieniowym. Menu rozpisane na dany tydzień jest zawsze dostępne w żłobku do wglądu dla rodziców.

Istotną kwestią jest szacunek wobec małego dziecka podczas spożywania posiłków. Nie jest to łatwy czas dla pań w grupach, ich podopieczni bowiem często nie są nauczeni siedzenia przy stole, a także kulturalnego zachowania się podczas jedze-

${ }^{1}$ Wytyczne dotyczące żywienia dzieci w żłobkach znajdują się w poradniku Żywienie dzieci $w$ żłobkach. Praktyczne wprowadzenie aktualnych norm i zaleceń, Stowarzyszenie „Zdrowe Pokolenia", Warszawa 2018. 
nia. Tego w wielu przypadkach maluchy uczą się w żłobku. Ważne, by w tym czasie zapewnić im przyjazną i spokojną atmosferę. Zarówno werbalne, jak i pozawerbalne sygnały świadczące o tym, ile, jak i czy w ogóle dziecko chce jeść, muszą być zauważone i respektowane. Jednocześnie szanowana jest każda forma spożywania posiłku przez dzieci. Maluchy mają prawo jeść rękami, choć zawsze otrzymują sztućce. Mogą jednak nie chcieć z nich korzystać. Należy pamiętać, że dziecko ma prawo odmówić spożycia posiłku. Niedopuszczalne jest karanie podopiecznego z powodu jego niechęci do jedzenia. Natomiast warto zachęcać dzieci do próbowania i opowiadać z zachwytem o serwowanym pożywieniu.

Właściwy plan dnia ma gwarantować bezpieczny, przyjazny, sprzyjający zdrowiu pobyt dzieci w placówce. W rzeczywistości godziny pracy danego żłobka są uwarunkowane potrzebami rodziców, którzy muszą rano powierzyć swoje pociechy pani opiekunce i po pracy zdążyć je odebrać przed zamknięciem placówki.

\section{Przykładowy plan dnia wygląda następująco:}

6:30-8:00 - w tych godzinach następuje powitanie, zabawy swobodne i konstrukcyjne, indywidualne zabawy $\mathrm{z}$ dziećmi potrzebującymi wsparcia w rozwoju, poranna gimnastyka.

8:00-8:15 - I śniadanie - dzieci, nie spiesząc się, jedzą to, co zostało dla nich przygotowane. To ważny czas, kiedy można uczyć kultury zachowania się przy stole. Oczywiste jest to, że część podopiecznych je jeszcze nieporadnie, ale dużą rolę przywiązuje się do nauki samodzielności. Panie opiekunki zachęcają do próbowania, ale nie zmuszają.

9:00-9:15 - toaleta - dzieci myją zęby, korzystają z nocników lub toalety, myją ręce.

9:15-11:30 - dzieci uczestniczą w zajęciach. Dwa razy w tygodniu odbywa się rytmika. Cyklicznie przyjeżdżają aktorzy ze spektaklem dla dzieci. Gdy tylko aura na to pozwala, należy spędzać z dziećmi czas na świeżym powietrzu.

10:00-10:15 - II śniadanie, np. owoce.

11:45-12:15 - obiad/II danie.

Do godz. 13:45 - drzemka poobiednia.

14:00-14:15 - druga faza obiadu - zupa.

15:00 - podwieczorek.

Do godz. 17:30 - zabawy dowolne. Gdy tylko aura na to pozwala, należy spędzać z dziećmi czas na świeżym powietrzu.

Dużo czasu w organizacji dnia zajmują czynności samoobsługowe. Warto pamiętać, że małe dzieci potrzebują odpowiedniej ilości czasu, aby nauczyć się korzystać z toalety, samodzielnie jeść czy podejmować próby samodzielnego ubierania się.

W realizacji funkcji opiekuńczej znaczące są pierwsze doświadczenia dziecka w żłobku. Od dobrej adaptacji i poczucia bezpieczeństwa u maluchów i ich rodziców zależy bowiem dalsze ich funkcjonowanie w tym miejscu. Czynnikami, które mogą ułatwić lub utrudnić proces adaptacji, są: liczba dzieci w grupie, liczba dorosłych 
opiekunów i ich przygotowanie, stosowane metody wychowawcze. Jeżeli dziecko w żłobku ma zagwarantowaną fachową opiekę, odpowiednią liczbę opiekunek, zapewniającą indywidualny, bliski kontakt z podopiecznym, to zostają spełnione warunki do jego wszechstronnego rozwoju.

W związku z tym, że adaptacja jest procesem, który obejmuje nie tylko dziecko, mamę i tatę, lecz również innych członków najbliższej rodziny, dla zminimalizowania stresu towarzyszącego tej sytuacji i dla umożliwienia poznania placówki w żłobku organizowany jest corocznie na przełomie maja i czerwca dzień otwarty. Jest to okazja dla rodziców, dziadków i innych zainteresowanych osób do zobaczenia zajęć prowadzonych w żłobku i nawiązania indywidualnego kontaktu z personelem.

Pod koniec czerwca organizowane są zebrania dla rodziców dzieci przyjętych do żłobka w nowym roku szkolnym. Spotkania te służą przedstawieniu informacji o specyfice pracy w poszczególnych grupach rozwojowych. Oprócz kierownika i starszej pielęgniarki uczestniczy w nich psycholog, którego rolą jest przybliżenie zagadnień dotyczących adaptacji dziecka i rodziców do nowych warunków. Rodzice otrzymują również ulotki z najważniejszymi treściami pomocnymi zarówno przed przyprowadzeniem dziecka, jak i w pierwszych dniach września podczas pobytu w żłobku. W czasie zebrania przekazywane są także informacje dotyczące emocji, jakie towarzyszą rodzicom w pierwszych dniach września. Rolą rodzica jest zapanowanie nad trudnymi emocjami (choć nie jest to łatwe) - niezbędne do tego, aby nie zakłócać poczucia bezpieczeństwa u dziecka.

W pierwszych dniach września mama lub tata może pozostawać w sali, dopóki ich dziecko nie zaufa wychowawczyni. Towarzyszenie bliskiej osoby maluchowi łagodzi jego stres związany $\mathrm{z}$ nową dla niego sytuacją. Zadaniem rodzica jest zapoznanie dziecka z nowym miejscem, opiekunami, innymi dziećmi. Widok rodzica wychodzącego z sali na coraz dłuższe okresy i powracającego może ukształtować u dziecka rytm skojarzeń: wyszedł - wrócił. Podstawą do budowania pozytywnych relacji jest zaufanie, jakim rodzic powinien obdarzyć opiekunki pracujące z dzieckiem w grupie. Wzajemna współpraca rodziców z opiekunkami bardzo temu sprzyja.

Rodzice, towarzysząc dziecku w pierwszych dniach jego pobytu w żłobku, poznają zwyczaje panujące w grupie, obserwują innych rodziców, którzy opiekują się swoimi pociechami, wymieniają między sobą spostrzeżenia, wspólnie się wspierają. W momencie, kiedy muszą wyjść z sali, proszą się wzajemnie o pomoc, spojrzenie na dziecko, czy wszystko jest w porządku. Wchodzą także w bliższe relacje z opiekunkami, na bieżąco przekazują informacje dotyczące ich dziecka, jego przyzwyczajeń, upodobań itp.

Wspólne działania rodziców i kadry opiekuńczej skierowane na dobro dziecka sprzyjają pokonaniu trudności towarzyszących okresowi adaptacji, budują poczucie wzajemnego zaufania i w konsekwencji dziecko otoczone ciepłymi zapewnieniami odnajdzie w sobie siłę do tego, by sobie poradzić.

W przypadku rodzin dysfunkcyjnych żłobek pełni funkcję kompensacyjną. Dziecko ma zapewnione zdrowe, pełnowartościowe wyżywienie oraz aktywny roz- 
wój fizyczny, poznawczy i emocjonalno-społeczny. Możliwość długotrwałej obserwacji dziecka przez wychowawców i psychologa oraz pielęgniarkę odgrywa istotną rolę diagnostyczno-profilaktyczną w wykryciu zaburzeń rozwojowych i pozwala na podjęcie wczesnej interwencji terapeutycznej.

Rozporządzenie Ministra Rodziny Pracy i Polityki Społecznej w sprawie wymagań lokalowych i sanitarnych dotyczących żłobków i klubów dziecięcych określa minimalną liczbę metrów, jakie powinny przypadać na jedno dziecko w sali zabaw, nie mówi natomiast, co należy robić w tych pomieszczeniach, żeby dzieci rozwijały się optymalnie. Prawo nie określa jakości relacji z dziećmi, współpracy z rodzicami, programu rozwoju dzieci czy jakości dnia codziennego. Gminy, które od 4 kwietnia 2011 r. przejęły nadzór nad formami opieki nad dziećmi, osoby prowadzące te formy opieki oraz rodzice, którzy muszą podejmować decyzje o oddaniu dziecka do instytucji, potrzebują możliwych do osiągnięcia standardów wysokiej jakości wraz z mierzalnymi wskaźnikami².

W organizowaniu przestrzeni dla dziecka ważne jest miejsce do odpoczynku, zabawy, spożywania posiłku oraz łatwe wychodzenie na dwór - tarasy lub ogródek. Pomieszczenia i place zabaw powinny być dostosowane do potrzeb rozwojowych dzieci, bezpieczne i zapewniające potrzebę eksperymentowania oraz zaspokajające ciekawość malucha.

Prawa dziecka powinny być przestrzegane przez wszystkich pracowników. W żłobkach obowiązuje polityka ochrony dzieci przed krzywdzeniem, ochrona wizerunku dziecka, kodeks etyczny opiekuna.

Współpraca z rodzicami polega na szacunku, wsparciu i partnerstwie, opiekun udziela informacji o dziecku, rodzice mają wpływ na funkcjonowanie placówki. Okres adaptacji dziecka jest bardzo ważny dla poczucia bezpieczeństwa dziecka, jest organizowany zgodnie $\mathrm{z}$ indywidualnymi potrzebami i w jego najlepszym interesie. Ważna jest stałość opiekuna.

Przy powitaniu i pożegnaniu istotny jest kontakt z rodzicem, wymiana informacji o dziecku, brak pośpiechu, miła atmosfera. Dzieci mają zapewnione miejsce do odpoczynku (do poobiedniej drzemki) lub wypoczynku przy muzyce, bajce. Dzieci uczą się przestrzegania zasad higieny, korzystania z toalety, mycia twarzy, zębów i rąk.

${ }^{2}$ M. Rościszewska-Woźniak, Standardy jakości opieki i wspierania rozwoju dzieci do lat 3, Fundacja Rozwoju Dzieci im. J.A. Komeńskiego, Warszawa 2012. Zespół złożony z praktyków, ekspertów i rodziców powołany w kwietniu 2011 r. przez Fundację Rozwoju Dzieci im. J.A. Komeńskiego podjął się tego zadania. Zostało wypracowanych osiem standardów jakości opieki i wspierania rozwoju dzieci do lat 3. Są to: przestrzeń dla dzieci, prawa dziecka, profilaktyka zdrowia dzieci i zapobieganie wypadkom, współpraca z rodzicami i rodzinami dzieci, adaptacja dzieci i przejście z grupy do grupy, sytuacje codzienne (powitanie, pożegnanie, posiłki, odpoczynek, toaleta), zabawa dzieci (warunki do zabaw, planowanie i dokumentowanie), kompetencje opiekunów. Podstawowe warunki opieki, według tego zespołu, to liczba dzieci w grupie nie więcej niż 15 i 3 opiekunów, oraz zasada mówiąca, że im mniejsze dziecko, tym krótszy czas jego przebywania w placówce opiekuńczej. 
Zabawa pełni ważną funkcję w rozwoju poznawczo-społecznym dziecka. Realizowane są programy dydaktyczno-wychowawcze. Praca z dziećmi jest planowana i dokumentowana. Podopieczni mają możliwość wyboru zabawy czy aktywności bądź odmowy w nich udziału.

W żłobku powyżej 20 dzieci ustawa nakłada obowiązek zatrudnienia pielęgniarki, której zadaniem jest dbać o profilaktykę zdrowia i zapobieganie wypadkom oraz nadzorować czystość pomieszczeń. Pielęgniarka w placówce opiekuńczo-wychowawczej pełni wiele zadań z zakresu działalności opiekuńczej, wychowawczej i edukacyjnej, jak również tych związanych z zapewnieniem bezpieczeństwa i właściwych warunków sanitarno-epidemiologicznych.

Osoba na tym stanowisku współpracuje z opiekunkami i psychologiem w obszarze opieki nad dziećmi. Codziennie dokonuje wizualnej oceny stanu zdrowia podopiecznych przyjmowanych do żłobka. Prowadzi dokumentację pielęgnacyjną i odpowiada za jej archiwizację. Każdego dnia sprawdza frekwencję dzieci i sporządza sprawozdania. Sprawuje nadzór nad układaniem ramowego planu dnia. Może prowadzić zajęcia opiekuńczo-wychowawcze i edukacyjne oraz pracować z dziećmi w grupie. Nadzoruje pobyt dzieci na świeżym powietrzu i zaspokajanie ich potrzeb. Kontroluje wykonywanie codziennych zabiegów pielęgnacyjnych i usamodzielnianie maluchów. Współpracuje też z intendentem przy układaniu jadłospisu z uwzględnieniem diet. Następnie nadzoruje przygotowywanie mieszanek mlecznych i bezmlecznych zgodnie z zalecaną dietą.

W przypadku zauważenia objawów chorobowych pielęgniarka niezwłocznie powiadamia rodziców/opiekunów dziecka. Izoluje dziecko chore od dzieci zdrowych. W nagłych wypadkach udziela pierwszej pomocy przedlekarskiej. W razie nieszczęśliwego wypadku udziela pomocy dziecku i zgłasza informację o wydarzeniu do kierownika. Ma obowiązek pozostać w pracy do czasu przybycia rodziców/opiekuna dziecka.

Pielęgniarka współtworzy i razem z pracownikami żłobka realizuje program profilaktyki i promocji zdrowia. Pełni nadzór nad czystością zabawek i innych pomocy oraz eliminuje te niebezpieczne lub uszkodzone. To jej akceptacji wymagają zabawki i pomoce, które trafiają do żłobka jako darowizna lub użyczenie.

Pielęgniarka jest odpowiedzialna za spełnianie warunków sanitarno-epidemiologicznych w placówce i przez pracowników. Przestrzega ważności badań okresowych i terminów zaświadczeń do celów sanitarno-epidemiologicznych. Kontroluje stan apteczki żłobka i wydawanie środków farmaceutycznych.

\section{Realizacja funkcji wychowawczej i edukacyjnej}

Artykuł 48 Konstytucji Rzeczypospolitej Polskiej stanowi, że rodzice mają prawo wychowywać dziecko zgodnie z własnymi przekonaniami, np. religijnymi, pedago- 
gicznymi, psychologicznymi. Państwo ma obowiązek wspierać rodzinę w realizacji jej funkcji opiekuńczych, wychowawczych, edukacyjnych. Wspierać - to znaczy stworzyć rodzinie możliwości instytucjonalne, prawne, finansowe, organizacyjne pozwalające wychować dziecko. Ale wsparcie to także informacja, wiedza, uczenie się, jak wychowywać dziecko, co to znaczy być dobrym rodzicem. Rodzice są partnerami instytucji opiekuńczych i edukacyjnych i to od rodziców w dużym stopniu zależy to, jak te instytucje będą pracować.

Ustawa z dnia 4 lutego 2011 r. o opiece nad dzieckiem do lat 3 (Dz.U. z 2018 r., poz. 603 z późn. zm.) określa wymagania kwalifikacyjne opiekunów w żłobku. Mogą nimi być osoby posiadające: dyplom pielęgniarki, położnej, opiekuna dziecięcego, nauczyciela wychowania przedszkolnego, edukacji wczesnoszkolnej, pedagoga opiekuńczo-wychowawczego, społeczno-wychowawczego, wczesnej edukacji, terapeuty pedagogicznego lub osoby, które ukończyły studia lub studia podyplomowe na kierunkach lub specjalności: wczesne wspomaganie rozwoju, wspomaganie rozwoju dzieci w ramach pomocy psychologiczno-pedagogicznej w żłobkach i przedszkolach, edukacja prorozwojowa, pedagogika małego dziecka, psychologia dziecka, psychologia wspierania rozwoju i kształcenia lub psychologia wychowawcza. Opiekunem w żłobku lub klubie dziecięcym może być także osoba, która posiada wykształcenie średnie lub średnie branżowe i odbyła 280-godzinne szkolenie przed zatrudnieniem.

Wychowawca w żłobku pełni ważną funkcję w życiu dziecka. Spędza z nim często więcej czasu niż matka, kompensuje mu brak bliskości rodzica. Uczy podopiecznego zasad higieny, samodzielności, zachowań społecznych, okazuje mu troskę i uwagę. Sukces wychowawczy zależy od zaangażowania wszystkich osób zajmujących się dzieckiem.

Zarówno wychowawcy w żłobku, jak i rodzice często skarżą się na trudności wychowawcze. Problemem, z którym muszą sobie radzić, jest fakt odmawiania wykonania poleceń, nieposłuszeństwo, napady złości, agresji u dzieci. Zadaniem psychologa w żłobku jest wsparcie rodziców i opiekunów w procesie wychowawczym. Obserwując funkcjonowanie dziecka w żłobku, może on służyć rodzicom wiedzą, informacją, gdzie mogą otrzymać potrzebną pomoc, jakie są najskuteczniejsze metody wychowawcze.

Małe dziecko najbardziej potrzebuje kontaktu indywidualnego, bliskości dorosłego. Zachowania społeczne pojawiają się dopiero później, w trakcie życia żłobkowego, gdy dziecko osiągnie poczucie bezpieczeństwa i będzie gotowe na kontakty z rówieśnikami. Okres adaptacji jest bardzo ważny, ponieważ dziecko w obecności bliskiej osoby poznaje opiekunów i otoczenie, czuje się bezpieczne, bo sytuacja staje się przewidywalna, rozumie, że rodzic wróci.

Podczas zabawy dzieci decydują, czym chcą się bawić. Opiekun przygotowuje otoczenie, aby było ciekawe, inspirujące, towarzyszy dzieciom, rozmawia z nimi, nazywa przedmioty, ogląda książeczki, opisując, co widzi, razem z nimi rysuje, maluje, lepi. Zabawki i otoczenie muszą być dla dzieci bezpieczne, szuflady zabezpieczone blokadą, półki niskie, aby maluchy mogły sięgnąć po zabawkę, nie wspinając się. 
W pracy z dziećmi bardzo ważne jest wyznaczanie granic, rytuały i konsekwencja. Podopieczni powinni wiedzieć, że słowo „nie” oznacza zakaz, brak zgody, a nie przekomarzanie się.

Konsekwencje tym się różnią od kar, że nie krzywdzą, a uczą. Są one naturalne: dziecko zbiło kubek - nie ma już kubka, oraz logiczne, czyli są następstwem zachowania, np. dziecko nie zjadło obiadu, więc czeka do następnego posiłku. Stosowanie konsekwencji nie rani uczuć wychowanków. Uczy dyscypliny, znoszenia porażek. Najważniejsze w wychowaniu to miłość i szacunek do dzieci. Dyscyplina pomaga w osiąganiu sukcesów, uczy, że wysiłek się opłaca. Pomagamy dzieciom znieść porażkę, rozmawiając, przytulając, ustalając plan, żeby następnym razem było lepiej. Pytamy się, w czym możemy pomóc, razem szukamy rozwiązań, proponując coś miłego. Ważne, żeby zauważyć i docenić w dzieciach zalety, talenty, wzmacniać je, nie stawiać nadmiernych wymagań.

Funkcja wychowawcza w żłobku jest realizowana w wielu aspektach, zarówno tych dotyczących samych dzieci, jak i ich rodziców. Ważne miejsce zajmuje nauka kulturalnego zachowania się w grupie. Już od najmłodszych lat wyrabiamy w dzieciach nawyk ładnego witania się i pożegnania, przepraszania, dziękowania, kulturalnego zachowania się przy stole, wspólnej zgodnej zabawy i dzielenia się zabawkami. To ważne umiejętności społeczne, dzięki którym podopieczni będą lepiej postrzegani przez otoczenie, a co za tym idzie - łatwiej będzie im funkcjonować w społeczeństwie.

\section{Podsumowanie}

Żłobki publiczne w polskich realiach stały się pożądanym przez wielu młodych rodziców miejscem opieki i wychowania dla najmłodszych obywateli. To nie przechowalnie, jak można usłyszeć od starszego pokolenia, lecz miejsca, które uczą i wychowują. Niezaprzeczalnie publiczne żłobki dbają o dobro swoich podopiecznych: dają poczucie bezpieczeństwa, ważności, sprawstwa. Trzeba jednak pamiętać, że mimo wysokich standardów są to placówki, która mają wspomagać rodzinę w opiece i wychowaniu małych dzieci, a nie ją zastępować.

\section{Bibliografia}

Rościszewska-Woźniak M., Standardy jakości opieki $i$ wspierania rozwoju dzieci do lat 3, Fundacja Rozwoju Dzieci im. J.A. Komeńskiego, Warszawa 2012.

Sakowska J., Szkoła dla rodziców i wychowawców, CMPPP MEN, Warszawa 1999.

Ustawa z dnia 4 lutego 2011 r. o opiece nad dziećmi w wieku do lat 3. Załącznik do obwieszczenia Marszałka Sejmu Rzeczypospolitej Polskiej z dnia 6 marca 2018 r. (poz. 603). 
Ustawa z dnia 7 lipca 2017 r. o zmianie niektórych ustaw związanych z systemami wsparcia rodzin (Dz.U. z 2017 r., poz. 1428, art. 22, obowiązuje od 1.01.2018 r.). Żywienie dzieci $w$ żłobkach. Praktyczne wprowadzenie aktualnych norm i zaleceń, Stowarzyszenie „Zdrowe Pokolenia”, Warszawa 2018.

\section{Care, upbringing, education in the reality of Polish public nurseries}

Abstract: Work with young children is difficult, but it can give a lot of satisfaction. In nursery groups the most important factors are: children's safety, shaping the development of independent activities and awakening childrens' desire to explore the world. Nowadays, parents notice huge benefits of their child's participation in nursery life. This article is an analysis of the possibilities of shaping and supporting development offered by nurseries. The article makes use of the theoretical foundations of developmental psychology and pedagogy of young children, legal regulations for the functioning of nurseries, i.e. "Nursery law" and the author's own experience resulting from daily observation of working with young children. The article describes legal regulations and provides examples of real care, upbringing and educational activities that take place at nurseries.

Keywords: care, upbringing, little children's education, nursery

\footnotetext{
About the author: Doctor of Humanities, assistant professor at the Maria Grzegorzewska University in Warsaw, Centre of Little Children's Pedagogy. For three years she has been the manager of a public nursery in Warsaw. She is President of the Association for Supporting the Development of Children with Special Educational Needs. She deals with the issues of upbringing and education of children of nursery and preschool age and pedagogical innovations in the area of adult-child relations. Author of books and articles on helping children to function well at home, at nursery and at kindergarten.
} 


\title{
Katarzyna Miłek* (iD https://orcid.org/0000-0003-4603-4604
}

Gnieźnieńska Szkoła Wyższa Milenium

https://doi.org/10.25312/2083-2923.17/2020_05km

\section{Wpływ zabaw twórczych na rozwój języka mówionego u dzieci 5-letnich}

\begin{abstract}
Streszczenie: Autorka w artykule zaznacza, jak istotny wpływ mają zabawy twórcze w edukacji małego dziecka. Pełnią one wiele funkcji: wychowawczą, edukacyjną, diagnostyczną oraz terapeutyczną. Badania przeprowadzone przez autorkę potwierdzają przekonanie, że każdy nauczyciel pracujący z małymi dziećmi powinien zwrócić szczególną uwagę na to, aby każdy podopieczny mógł rozwijać przez zabawy twórcze nie tylko swój potencjał twórczy, ale przy okazji swoje predyspozycje do komunikowania się.

Słowa kluczowe: zabawa, język, twórczość, edukacja, dzieci
\end{abstract}

Podstawową formą wymiany myśli między ludźmi jest język, którego każdy uczy się od najmłodszych lat w procesie społecznego wychowania. Najczęściej przyjmowany jest on w sposób naturalny w kształcie, jaki przekazuje nam otoczenie. Wymowę dziecka wstępującego do przedszkola charakteryzuje już duża umiejętność odtwarzania wszystkich elementów słowa. Trzylatek powinien już wymawiać wszystkie samogłoski, tak ustne, jak i nosowe (a, o, e, u, i, y, ą, ę), chociaż w jego mowie mogą występować odstępstwa, np. zamiana samogłosek: $a=0 ; e=a ; i=y$. Pięciolatek potrafi się już porozumieć z dorosłymi, chociaż jego mowa nie jest tak ukształtowana pod względem dźwiękowym, jak np. sześciolatka.

Katarzyna Miłek - dr, adiunkt w Gnieźnieńskiej Wyższej Szkole Milenium. Pracę doktorską obroniła w 2017 r. na temat „Twórczość dzieci w zabawach przedszkolnych”. Zainteresowania: pedagogika ogólna, pedagogika przedszkolna, pedagogika twórczości. W badaniach naukowych koncentruje się na: twórczości pedagogicznej nauczyciela, zdolnym i twórczym dziecku, przemianach w edukacji przedszkolnej i wczesnoszkolnej. 
Mowa pięciolatka jest już w zasadzie zrozumiała. Głoski sz, ż, cz, dż, które się pojawiły w 4. roku życia, zaczynają się ustalać. Dziecko potrafi je poprawnie powtórzyć, choć w mowie potocznej mogą jeszcze być wymawiane jak: s, z, c, dz. Głoska r powinna już być wymawiana, ale często pojawia się dopiero w tym okresie. Grupy spółgłoskowe jeszcze są upraszczane, zarówno w nagłosie wyrazu, jak i w śródgłosie.

U sześciolatków mowa powinna już być opanowana pod względem dźwiękowym. Mimo tej reguły T. Bartkowska wykrywa jeszcze nieopanowaną wymowę głosek sz, z, cz, dz, r. Zdarzają się kłopoty z realizacją grup spółgłoskowych, zwłaszcza w śródgłosie wyrazu.

Przedstawiony wyżej rozwój mowy postępuje równolegle z rozwojem motoryki narządów artykulacyjnych. Mówienie jest sprawnością i trzeba się jej uczyć, tak jak wszelkich innych sprawności. Jest to możliwe dzięki sukcesywnemu dojrzewaniu różnych organów mowy. Po narodzinach dziecka żaden $z$ tych narządów nie jest jeszcze gotowy do swych czynności. Mowa wytwarza się dzięki skoordynowanej aktywności muskulatury języka, warg, gardła, podniebienia, krtani i płuc. Do rozwoju i koordynacji poszczególnych części wchodzących w skład skomplikowanego narządu mowy potrzebny jest określony czas i aktywne ćwiczenia ${ }^{1}$.

Zasób słownictwa, jakim dysponuje dziecko, ma duże znaczenie w procesie komunikowania się w grupie, $\mathrm{z}$ otoczeniem, kształtowania różnorodnych form jego działalności, rozwoju psychicznego.

Dzieci w wieku przedszkolnym tworzą wiele nowych słów, tzw. neologizmów. W ich budowaniu korzystają z zasad gramatyki języka ojczystego, a wykazują tendencję do tworzenia, występując w roli „genialnego lingwisty”, który dobrze zna reguły gramatyczne. Po tym okresie zanika ta skłonność. Nadal jednak dzieci przejawiają zdolność do tworzenia nowych słów przez analogię do już znanych, co pełni funkcję wypełniania luk w sytuacji, gdy dziecko nie znajduje w swoim zasobie słownictwa nazwy na określenie jakiegoś obiektu. Tworzenie nowych wyrazów odbywa się zgodnie $\mathrm{z}$ regułą produktywności (wybierane są formy preferowane w danej wspólnocie językowej), przejrzystości semantycznej (szukanie form jasno wyrażających znaczenie) i regularyzacji (używanie form regularnych, typowych dla danego języka) ${ }^{2}$.

Przedszkolak przed rozpoczęciem nauki szkolnej zaczyna twórczo posługiwać się językiem. Następuje moment kształtowania się wiedzy metajęzykowej. Dzieci zaczynają wówczas bawić się słowami, potrafią rymować, dostrzegać różnego rodzaju niuanse językowe, zauważać wieloznaczność wyrazów oraz fakt, że istnieją języki obce. Odchodzą też od bardzo dosłownego rozumienia słów i wyrażeń, w ich języku zaczynają pojawiać się wyrażenia, zwroty, słowa o znaczeniu metaforycznym. Jako pierwsze - z oczywistych powodów o wyższej frekwencji w mowie potocznej - po-

${ }^{1}$ G. Demelowa, Elementy logopedii, Wydawnictwa Szkole i Pedagogiczne, Warszawa 1987, s. 24.

${ }^{2}$ B. Harwas-Napierała, J. Trempała, Psychologia rozwoju człowieka. Charakterystyka okresów życia człowieka, Wydawnictwo Naukowe PWN, Warszawa 2000, s. 107. 
jawiają się wyrażenia metaforyczne silnie zleksykalizowane. Sześciolatek potrafi już sam tworzyć wypowiedzi o charakterze przenośnym.

W ciągu okresu przedszkolnego dziecko stopniowo poszerza swój słownik i operuje coraz sprawniej regułami fonetycznymi i gramatycznymi. W wieku sześciu lat posługuje się już swobodnie mową potoczną, zależną i niezależną oraz porozumiewa się bez trudu z innymi ludźmi, przekazując im swoje myśli, pragnienia, żądania, emocje i uczucia.

W okresie przedszkolnym dokonuje się intensywny rozwój dziecka, co następuje przez zabawę. Zadaniem nauczycieli w przedszkolu jest kształtowanie sprawności mówienia oraz myślenia dzieci ${ }^{3}$ które podczas zajęć uczą się poprawnych i swobodnych wypowiedzi na tematy związane z emocjami i przeżyciami ich oraz bohaterów przedstawianych przez nauczyciela bajek. Praca nad językiem i procesami poznawczymi dziecka wymaga systematycznych ćwiczeń w zakresie formy dźwiękowej (przede wszystkim wymowy), słownictwa, form gramatycznych, konstrukcji składniowych tak w wypowiedziach wielozdaniowych, jak i w rozmowie. Ćwiczenia te w przedszkolu - ze względu na charakterystyczne cechy dziecka - muszą mieć charakter zabawy.

D.D. Smith uważa, że „w trakcie zabawy dzieci uczą się zachowań społecznych, interakcji z innymi i współpracy. Poprzez odkrywanie i badanie rzeczywistości w różnych rodzajach zabaw dzieci poznają swoje otoczenie, rozwijają sprawność motoryczną i wzbogacają swój język"4.

Zabawa dzieci w wieku przedszkolnym dostarcza im nie tylko przyjemności, ale kształtuje ich osobowość, wpływa na rozwój, uczą się języka oraz funkcjonowania w otaczającym je świecie. Poznają rzeczywistość, czerpiąc z niej coraz większą wiedzę o życiu, uczą się relacji społecznych, co jest prawdziwym przygotowaniem do życia w dorosłości.

Zabawy dziecięce podlegają w psychologii i pedagogice różnej hierarchizacji. Wśród nich wyróżnia się: zabawy tematyczne, manipulacyjne i konstrukcyjne, ruchowe oraz dydaktyczne 5 .

W zabawach tematycznych elementem zasadniczym jest przyjęcie przez dziecko określonej roli. Olbrzymie znaczenie ma jego wyobraźnia, dzięki której buduje swój odrębny, fikcyjny świat. Żyje w nim podczas zabawy, ale ma przez cały czas poczucie realności i jest w stanie wrócić do prawdziwego świata. Charakterystyczne jest też nadawanie różnych znaczeń przypadkowym przedmiotom używanym w zabawie. Dziecko naśladuje najczęściej czynności dorosłych, występujące między nimi relacje, stosunki społeczne, a także sytuacje znane z książek, filmów czy bajek ${ }^{6}$.

${ }^{3}$ M. Bober-Pełzowska, Rozwijanie mowy u uczniów klas niższych, Wydawnictwa Szkolne i Pedagogiczne, Warszawa 1983, s. 91-94.

${ }^{4}$ D.D. Smith, Pedagogika specjalna, t. 2, przeł. A.J. Korbel, Wydawnictwo Naukowe PWN, Warszawa 2009, s. 144.

${ }^{5}$ J. Truskolaska, Osoba i zabawa, Wydawnictwo KUL, Lublin 2007, s. 57.

6 Tamże. 
Zabawy konstrukcyjne to te, w których zasadniczym elementem jest układanie, lepienie, budowanie z różnorodnych materiałów: klocków, kamieni, patyczków, pudełek, piasku i innych ${ }^{7}$.

U młodszych dzieci (do 3. roku życia) jest to zabawa manipulacyjna, której celem jest sama czynność, manipulacja przedmiotami. W zabawie konstrukcyjnej liczy się wytwór, produkt. Oprócz przyjemności wynikającej z działania powstaje przyjemność $\mathrm{z}$ wykonania czegoś i poznania tego przedmiotu.

W życiu dziecka duże znaczenie ma ruch, dlatego tak istotna jest wówczas zabawa ruchowa. Chodzi o działanie dużych grup mięśniowych, a nie, jak w zabawach manipulacyjnych, o ruchy przede wszystkim rąk i palców. Do zabaw ruchowych zaliczymy: bieganie, skoki, ślizganie się, huśtanie, przewracanie itp. ${ }^{8}$

Wyróżnia się jeszcze zabawy dydaktyczne, czyli takie, które służą procesowi nauczania i uczenia się dziecka. Najczęściej są one organizowane przez wychowawców. Do tej grupy nie zalicza się jednak wszelkich gier i zabaw aranżowanych przez rodziców i nauczycieli w celach dydaktycznych, ale (niezgodnie z nazwą) tylko loteryjki, zagadki, segregowanie obrazków i inne podobnego typu. Ich cechą charakterystyczną jest to, że dziecko musi podporządkować się określonym, narzuconym z góry regułom i przepisom 9 .

W okresie dzieciństwa twórczość realizuje się właśnie w zabawie, w której dziecko wykorzystuje swoją moc tworzenia symboli ${ }^{10}$.

Zdaniem D. Kubickiej, „zabawa dostarcza dziecku przede wszystkim przyjemności i wiedzy, a rezultatem jego działań może być powstanie twórczego dzieła"11.

Do twórczych zaliczyć można także zabawy konstrukcyjne. Każda konstrukcja jest dla dziecka trudnym problemem do rozwiązania. Dziecko samo wymyśla kompozycję i jej rozwiązania techniczne, stara się pokonać siebie, a realizacja własnego pomysłu ma właśnie pierwiastek twórczy ${ }^{12}$.

Zabawy fikcyjne, często nazywane iluzyjnymi, u dzieci pojawiają się około 2. roku życia, osiągając szczyt rozwoju dopiero cztero-, pięciolatków.

L. Wygotski uważa, że zabawa symboliczna $\mathrm{z}$ wiekiem staje się narzędziem twórczości ${ }^{13}$. D.B. Elkonin również twierdzi, że „zabawa symboliczna realizuje się w świecie znaków, znaczeń i ich interpretacji, w obszarze relacji między znakami a zna-

7 Tamże.

8 Tamże.

9 W. Okoń, Zabawa a rzeczywistość, Wydawnictwa Szkolne i Pedagogiczne, Warszawa 1987, s. 147.

10 Tamże.

11 D. Kubicka, Twórcze działanie dziecka w sytuacji zabawowo-zadaniowej, Wydawnictwo Uniwersytetu Jagiellońskiego, Kraków 2003, s. 104.

12 Tamże, s. 21.

13 Za: tamże, s. 103. 
czeniami, które są podatne na interpretacje, rozciągliwe i właśnie dlatego stwarzają okazję do twórczości"14.

Dzieci nie są przygotowane do tego, aby tworzyć cokolwiek w świecie realnym, wobec tego swoje działania twórcze realizują w świecie wyobraźni i zabawie. W świecie tym zabawa może stać się polem dla poczynań twórczych.

Podczas zabaw twórczych dziecko układa scenki według odpowiedniego sposobu myślenia i percepcji działania. Wykorzystuje różne rekwizyty - zabawki. Układa z nich obiektywnie powiązane i spójne całości. Stara się uporządkować swoje działania w logiczną całości i jednocześnie je uzasadnić. D. Kubicka stwierdza, że wówczas bawiące się dziecko „postępuje jak człowiek, u którego dominują zewnętrzne standardy regulacji: dane percepcyjne i racjonalny punkt widzenia"15.

Dzieci podczas zabawy twórczej, układając scenki, często wprowadzają elementy manipulacyjne, tematyczne (i inne), które świadczą o dynamizowaniu ich działań. Często także w trakcie odgrywania scenki poprawiają, korygują i modyfikują swoje działania. Zmieniają często swoje koncepcje, starając się w jak najlepszy sposób przedstawić swoje pomysły. Te zachowania dzieci świadczą o ich aktywnym poszukiwaniu subiektywnych doznań i przeżyć podczas zabawy twórczej.

Twórczość przedszkolaków ujawnia się w warunkach dla nich korzystnych, zapewniających im poczucie bezpieczeństwa, a one same czerpią inspiracje z otaczającego środowiska. Dlatego badania procesu twórczego dzieci, który przebiega w toku zabaw, odbywają się w trakcie ich trwania. Zabaw twórcze rozwijają również język twórczy przez stwarzanie ich uczestnikom możliwości wyrażania siebie i swoich myśli. Podczas zabaw dzieci wprowadzają nowe elementy, szukają nowych rozwiązań, które różnią się od pomysłów innych. Cieszą się, gdy mogą wypowiadać nowe dźwięki dające nowe wyrazy, bawiąc się jednocześnie ich znaczeniem. Język mówiony stanowi formę aktywności twórczej. Tę aktywność twórczą możemy obserwować u dzieci przedszkolnych przede wszystkim w zabawie.

Cechą twórczości dzieci w zabawach jest zacieranie się świata fikcji i rzeczywistości. Nie przyjmują one żadnych autorytetów, a ich fantazja ma możliwość rozwijania się.

Te swoiste cechy twórczości językowej u przedszkolaków stały się przedmiotem badań, które przeprowadzono w dwóch grupach liczących po 30 dzieci, tj. 15 dziewczynek i 15 chłopców w każdej grupie.

Na pierwszym etapie badań przeprowadzono w obu grupach testy mające na celu:

1) wyłonienie grupy kontrolnej - A, która we wstępnych badaniach uzyskała najlepsze wyniki i w której jest najwięcej osób twórczych,

2) wyłonienie grupy eksperymentalnej oznaczonej literą B, w której we wstępnych badaniach odnotowano najsłabsze wyniki, czyli jest w niej najmniej dzieci twórczych.

${ }^{14}$ D.B. Elkonin, Psychologia zabawy, przeł. L. Łoś, WSiP, Warszawa 1984, s. 284.

${ }^{15}$ D. Kubicka, dz. cyt., s. 141. 
W grupie eksperymentalnej zrealizowano drugi etap badań, który polegał na wprowadzeniu zabaw twórczych mających na celu rozwijanie języka twórczego dzieci.

Na końcowym trzecim etapie badań znów przeprowadzono identyczne badania jak podczas pierwszego etapu w celu stwierdzenia, czy eksperyment przyniósł rezultaty, czyli czy u dzieci rozwinął się język twórczy.

Przed realizacją eksperymentu w obu grupach otrzymano wyniki, które przedstawia tabela 1 .

Tabela 1. Poziom twórczego języka mówionego dzieci 5-letnich na I etapie badań z grupy A i B

\begin{tabular}{|c|c|c|c|c|c|c|}
\hline Lp. & $\begin{array}{c}\text { Kolejne badane } \\
\text { dziecko }\end{array}$ & Liczba pkt & $\begin{array}{l}\text { Poziom języka } \\
\text { twórczego }\end{array}$ & $\begin{array}{l}\text { Kolejne badane } \\
\text { dziecko }\end{array}$ & Liczba pkt & $\begin{array}{l}\text { Poziom języka } \\
\text { twórczego }\end{array}$ \\
\hline 1 & A. Julia & 18 & średni & G. Julia & 12 & niski \\
\hline 2 & B. Gabriela & 19 & średni & K. Weronika & 16 & średni \\
\hline 3 & C. Amelia & 15 & średni & K. Michalina & 11 & niski \\
\hline 4 & D. Zuzanna & 30 & wysoki & K. Julia & 11 & niski \\
\hline 5 & P. Julia & 11 & niski & M. Zofia & 10 & niski \\
\hline 6 & P. Zuzanna & 14 & średni & M. Natasza & 10 & niski \\
\hline 7 & S. Anna & 17 & średni & S. Aleksandra & 14 & średni \\
\hline 8 & S. Julia & 17 & średni & S. Natalia & 10 & niski \\
\hline 9 & S. Aleksandra & 11 & niski & S. Martyna & 11 & niski \\
\hline 10 & Z. Julia & 12 & niski & F. Maja & 12 & niski \\
\hline 11 & A. Oliwia & 11 & niski & B. Michalina & 13 & niski \\
\hline 12 & W. Natalia & 9 & niski & W. Zuzanna & 29 & wysoki \\
\hline 13 & G. Nadia & 13 & niski & S. Julia & 26 & wysoki \\
\hline 14 & T. Antonina & 17 & średni & S. Julia & 18 & średni \\
\hline 15 & W. Lena & 19 & średni & B. Antonina & 18 & średni \\
\hline 16 & J. Szymon & 31 & wysoki & W. Bartosz & 17 & średni \\
\hline 17 & K. Igor & 17 & średni & Ś. Dariusz & 13 & niski \\
\hline 18 & Ś. Wiktor & 18 & średni & J. Mateusz & 14 & średni \\
\hline 19 & P. Kacper & 17 & średni & J. Antoni & 12 & niski \\
\hline 20 & T. Igor & 17 & średni & S. Mateusz & 13 & niski \\
\hline 21 & S. Krzysztof & 20 & średni & K. Jakub & 11 & niski \\
\hline 22 & T. Dawid & 11 & niski & L. Dawid & 13 & niski \\
\hline 23 & W. Mikołaj & 11 & niski & M. Stanisław & 13 & niski \\
\hline 24 & W. Dawid & 11 & niski & P. Borys & 12 & niski \\
\hline 25 & W. Mateusz & 11 & niski & P. Igor & 11 & niski \\
\hline 26 & K. Igor & 10 & niski & S. Antoni & 12 & niski \\
\hline 27 & D. Nikodem & 12 & niski & G. Filip & 13 & niski \\
\hline 28 & T. Mikołaj & 15 & średni & S. Antoni & 19 & średni \\
\hline 29 & S. Nikodem & 12 & niski & G. Bartosz & 18 & średni \\
\hline 30 & T. Kuba & 17 & średni & M. Aleksander & 18 & średni \\
\hline
\end{tabular}

Źródło: badania własne. 
Suma punktów uzyskanych przez dzieci w tych badaniach wyznacza poziom języka twórczego dzieci. Na tej podstawie został określony poziom twórczości dzieci w grupie A i B.

Wyniki uzyskano na podstawie arkuszy badań, w których uwzględniono cechy języka twórczego występujące u dzieci (tabela nr 1 i 2 i w aneksie 1 i 2).

Przeprowadzono test twórczości językowej pozwalający na dokonanie analizy, twórczości leksykalnej, semantycznej, syntaktycznej i tekstowej dzieci.

Twórczość językową dziecka badano, kierując doń trzy rodzaje poleceń o różnym stopniu trudności:

1) Popatrz i opowiedz mi o tym, co się dzieje na obrazku? (zadanie o najniższym poziomie trudności);

2) Popatrz i opowiedz mi o tym, co się dzieje na obrazkach? Co wydarzyło się przedtem? (zadanie o wyższym poziomie trudności);

3) Jak wygląda Twój pokój? Opowiedz mi o tym, abym potrafiła go sobie wyobrazić (zadanie o najwyższym poziomie trudności).

Dzieci miały więc do wykonania trzy zadania o różnym poziomie trudności (łatwe, średnio trudne i trudne). Podczas badania każde mogło otrzymać od 7 do 31 punktów. Suma punktów uzyskanych przez każde dziecko w tych badaniach wyznacza poziom języka twórczego badanej osoby.

W zakresie twórczości leksykalnej za odmianę wyrazów dzieci mogły otrzymać 1 pkt. W grupie A 18 dzieci uzyskało po 1 pkt, w tym 10 pkt otrzymały dziewczynki, 8 pkt chłopcy. W grupie B wszystkie dzieci otrzymały punkty za twórczość leksykalną.

Dzieci w swoich wypowiedziach stosowały neologizmy, zdrobnienia i zgrubienia, epitety, porównania, hiperbole, animizacje, personifikacje, alegorie i symbole, co dotyczy twórczości semantycznej. Za brak takiego środka w swojej wypowiedzi dziecko otrzymywało 0 pkt, natomiast za każdy użyty środek 1 pkt. W grupie A tylko jedno dziecko otrzymało 4 pkt, 3 dzieci po 3 pkt, 6 dzieci po 2 pkt; w grupie B - 10 dzieci po 1 pkt oraz 10 dzieci po 0 pkt za swoje wypowiedzi z zakresu twórczości leksykalnej, na przykład: „groźny kogut”, „szczęśliwa żabka”.

W wypowiedziach dzieci dokonywały także oceny, która przejawiała się użytymi inwersjami, elipsami, powtórzeniami, paralelizmami i anaforami, pytaniami retorycznymi z zakresu tzw. twórczości syntaktycznej. Za brak takiego środka dziecku przyznawano podczas wypowiedzi 0 pkt, natomiast za każdy użyty środek - 1 pkt.

W grupie A dzieci otrzymały bardzo mało punktów za twórczość semantyczną. Jedno dziecko uzyskało 3 pkt, 1 dziecko 2 pkt i 1 dziecko 1 pkt. Pozostałe 27 dzieci nie zdobyło żadnych punktów. W grupie B sytuacja przedstawiała się odmiennie. Tutaj 1 dziecko otrzymało 3 pkt, 6 dzieci 2 pkt i 10 dzieci 1 pkt.

Analiza wypowiedzi dzieci w zakresie twórczości tekstowej też nie przedstawia się najlepiej. Dzieci rzadko otrzymywały maksymalną liczbę punktów.

W zakresie fabularyzacji wypowiedzi (aneks 1 i 2, tabele 1 i 2, punkt IV.1 a) dzieci najczęściej otrzymywały po 1 pkt: w grupie A - 11 osób, natomiast w grupie B - 13 osób. 
Dzieci, wypowiadając się na temat obrazków, używały prostych zdań, nazywając czynności, które wykonują zwierzęta na obrazkach, posługując się pojedynczymi wyrazami lub równoważnikami zdań (IV.1 b).

Wypowiadały się pełnymi zdaniami, ale były to zdania proste i izolowane. Te dzieci otrzymały za swoje wypowiedzi po 2 pkt. W grupie A - było to 14 dzieci, natomiast w grupie B - 15 dzieci. Tylko u 5 dzieci z grupy A i 2 dzieci z grupy B zaobserwowano zwięzłą i logiczną składnię, co w pełni zapewniało jednoznaczny odbiór treści komunikatu. Dzieci te uzyskały po 3 punkty. W grupie A tylko 1 dziecko otrzymało 4 punkty, udzielając wypowiedzi spójnej i wartkiej (IV.1 d).

Ten typ odpowiedzi dotyczył pytań o małym i średnim stopniu trudności, okazały się jednak dla dzieci bardzo trudne. Tylko $7 \mathrm{z}$ nich potrafiło wymyśleć historię do obrazka, poprzedzającą przedstawioną na nim sytuację.

Dzieci umiały przedstawić swój pokój, określając kolor ścian, liczbę sprzętów znajdujących się w pomieszczeniach. Żadne nie opisało swojego domu tak, by można było go sobie wyobrazić. Dzieci fragmentarycznie dobierały słownictwo, co nie pozwoliło na wnikliwe zorientowanie się w temacie i treści przekazywanych informacji.

Dlatego też dzieci za wyczerpalność wypowiedzi otrzymywały tylko 1 pkt (IV.2 a), w grupie A była to 1 osoba, natomiast w grupie B - 14 osób.

Dzieci, które zwracały uwagę na kilka właściwości, elementów, cech zdarzeń w wypowiedzi, tylko częściowo pamiętały o istotnych elementach kontekstu, nie uwzględniały wszystkich wątków wypowiedzi, otrzymywały po 2 pkt. W grupie A było to 13 dzieci, natomiast w grupie B - 14 dzieci.

Natomiast wypowiedzi, w których ujęto wszystkie elementy, wymieniono wszystkie cechy zdarzenia, charakteryzowały się trafnością i jednoznacznością oraz właściwie informowały o zdarzeniach następujących po sobie, oceniane były na 3 pkt. W grupie A takich wypowiedzi udzieliło 12 dzieci, w grupie B tylko 2 dzieci.

Dzieci, które tworzyły w swojej wypowiedzi nowe linie narracji, wymyślając nowe sytuacje, otrzymywały 4 pkt. W grupie A było 4 takich dzieci, natomiast w grupie B żadne dziecko nie sprostało temu zadaniu.

Wszystkie zdarzenia opisywane przez dzieci przedstawione były w pełnym kontekście czasowym (IV.3 a, b, c, d). Użycie perspektywy czasowej pozwoliło na przyznanie punktacji. Za wypowiedź wyłącznie w czasie teraźniejszym - w grupie A - 1 dziecko otrzymało 1 pkt, w grupie B - tyle samo punktów uzyskało 13 dzieci. Za użycie częściowego kontekstu można było otrzymać po 2 pkt; w grupie A było 17 takich dzieci, natomiast w grupie B - 15 dzieci. Natomiast za umieszczenie przedstawionych zdarzeń w pełnym kontekście czasowym w grupie A po 3 pkt uzyskało 10 dzieci, w grupie B - 2 dzieci.

Dzieci, które potrafiły umieścić przedstawione zdarzenia w pełnym kontekście czasowym i podkreślały zmienność czasową opowiadanych wydarzeń, punktowane były najwyżej i mogły otrzymać po 4 pkt. Tylko 2 dzieci w grupie A otrzymało za swoje wypowiedzi najwyższą liczbę punktów. 
W zakresie ekspresji wypowiedzi ustnych (IV.4 a, b, c, d) dzieci również uzyskały niską punktację. Za obiektywną i lakoniczną relację przedszkolaki w grupie A - 3 osoby - otrzymały po 1 pkt. Tyle samo punktów w grupie B zdobyły 22 osoby. Wypowiedzi, w których dzieci potrafiły przedstawić wydarzenia nie tylko z pozycji widza, ale również uczestnika, miały wartość 2 pkt. Otrzymały je 24 osoby z grupy A i 7 dzieci z grupy B.

Dzieci, które potrafiły przedstawić zdarzenia na rysunku w kontekście własnych przeżyć, mogły otrzymać po 3 pkt. Zadanie to wykonało 3 dzieci z grupy A i 1 dziecko z grupy B. Nikt z badanych przedszkolaków nie otrzymał maksymalnej liczby punktów.

Również w zakresie emocjonalności (IV.5 a, b, c, d) wypowiedzi ustne dzieci oceniono nisko. W lakoniczny sposób opisywały zdarzenia, bez zwracania uwagi na przeżycia bohaterów, mówiły o ich zewnętrznych cechach (wygląd, co robi), używając słów niezabarwionych emocjonalnie, ale wypowiedzi te nie wpływały bezpośrednio na określone reakcje odbiorcy. Były oceniane na 1 pkt i otrzymało je 12 osób z grupy A i 7 osób z grupy B.

Dzieci, które potrafiły określić stan emocjonalny bohaterów, używając słów nacechowanych emocjonalnie, mogły otrzymać za taką wypowiedź po 2 pkt. W grupie A było 16 takich dzieci, natomiast w grupy B - 7 dzieci.

Wśród badanych przedszkolaków znalazło się 2 dzieci z grupy A i 3 dzieci z grupy $\mathrm{B}$, które otrzymały po 3 pkt za wypowiedzi odzwierciedlające sposób myślenia i wyrażania bohatera, potrafiące wyciągać własne wnioski i oceniające zdarzenia.

Żadne z dzieci nie otrzymało 4 pkt, które można było uzyskać za wyrażanie barwą i siłą głosu swoich emocji w związku z opowiadanym wydarzeniem.

Dzieci wypowiadały się ustnie w sposób mało oryginalny (IV.6 a, b, c, d). Wypowiedzi ich były poprawne, rzeczowe, ale schematyczne, wykorzystywały stereotypowe środki wyrazu oraz słownictwo powszechnie stosowane. Dlatego też w tym przypadku otrzymały najniższą punktację - 1 pkt. W grupie A było 20 takich dzieci, natomiast $\mathrm{w}$ grupie $\mathrm{B}-21$ dzieci.

Za wypowiedzi poprawne zabarwione emocjonalnie i za trafność doboru słownictwa 8 dzieci z grupy A i 7 dzieci z grupy B otrzymało po 2 pkt. Dwoje dzieci z grupy A i 2 dzieci z grupy B potrafiło w trakcie wypowiedzi fantazjować i używać rzadko spotykanych słów, za co otrzymały po 3 pkt.

Żadne z badanych dzieci nie uzyskało 4 pkt, gdyż nie potrafiły one wypowiadać się w poprawnej formie i stylu.

Również niską punktację dzieci otrzymały w zakresie złożoności wypowiedzi. Osiemnaścioro dzieci z grupy A i 18 dzieci z grupy B za wypowiedź monologową i prosty sposób przekazywania zdarzeń otrzymało po 1 pkt.

Natomiast 10 dzieci z grupy A i 10 dzieci z grupy B prowadziło monolog z intuicyjnie wkomponowaną mową pozornie zależną, za co otrzymały po 2 pkt.

Za złożoną wypowiedź, użycie zdań rozwiniętych i wielokrotnie złożonych dzieci mogły otrzymać po 3 pkt. W obu grupach takich osób było 2 . 
Żadne dziecko z obu grup nie uzyskało 4 pkt za wypowiedź z bogactwem środków składniowych. Warto dodać, że zadanie okazało się bardzo trudne. Dzieci z oporem brały w nim udział i trzeba było je bardzo zachęcać do udzielania wypowiedzi, $\mathrm{w}$ rezultacie w tym teście uzyskały niską punktację.

Na drugim etapie badań prowadzono w grupie B eksperyment, który trwał przez 26 tygodni. Polegał on na wprowadzeniu zabaw mających na celu wyzwalanie twórczości dzieci pięcioletnich. Zajęcia odbywały się dwa razy w tygodniu.

Trzeci etap badań obejmował przeprowadzenie ponownego testu, który miał miejsce przy wyłanianiu grupy kontrolnej i eksperymentalnej. Powtórne testy miały na celu:

1) stwierdzenie poziomu rozwoju cech twórczych języka u dzieci poddanych eksperymentowi oraz

2) określenie podobieństw i różnic w rozwoju języka twórczego dzieci z grupy kontrolnej i eksperymentalnej.

Tabela 2. Poziom twórczego języka mówionego dzieci 5-letnich na III etapie badań $z$ grupy A i B

\begin{tabular}{|c|c|c|c|c|c|c|}
\hline \multirow[b]{2}{*}{ Lp. } & \multicolumn{3}{|c|}{ GRUPA A } & \multicolumn{3}{|c|}{ GRUPA B } \\
\hline & $\begin{array}{c}\text { Kolejne badane } \\
\text { dziecko }\end{array}$ & Suma pkt & $\begin{array}{l}\text { Poziom języka } \\
\text { twórczego }\end{array}$ & $\begin{array}{l}\text { Kolejne badane } \\
\text { dziecko }\end{array}$ & Suma pkt & $\begin{array}{l}\text { Poziom języka } \\
\text { twórczego }\end{array}$ \\
\hline 1 & A. Julia & 20 & średni & G. Julia & 24 & wysoki \\
\hline 2 & B. Gabriela & 20 & średni & K. Weronika & 26 & wysoki \\
\hline 3 & C. Amelia & 17 & średni & K. Michalina & 26 & wysoki \\
\hline 4 & D. Zuzanna & 30 & wysoki & K. Julia & 24 & wysoki \\
\hline 5 & P. Julia & 11 & niski & M. Zofia & 25 & wysoki \\
\hline 6 & P. Zuzanna & 14 & średni & M. Natasza & 26 & wysoki \\
\hline 7 & S. Anna & 18 & średni & S. Aleksandra & 27 & wysoki \\
\hline 8 & S. Julia & 18 & średni & S. Natalia & 30 & wysoki \\
\hline 9 & S. Aleksandra & 11 & niski & S. Martyna & 28 & wysoki \\
\hline 10 & Z. Julia & 13 & niski & F. Maja & 24 & wysoki \\
\hline 11 & A. Oliwia & 12 & niski & B. Michalina & 26 & wysoki \\
\hline 12 & W. Natalia & 11 & niski & W. Zuzanna & 29 & wysoki \\
\hline 13 & G. Nadia & 13 & niski & S. Julia & 26 & wysoki \\
\hline 14 & T. Antonina & 18 & średni & S. Julia & 31 & wysoki \\
\hline 15 & W. Lena & 21 & średni & B. Antonina & 30 & wysoki \\
\hline 16 & J. Szymon & 31 & wysoki & W. Bartosz & 27 & wysoki \\
\hline 17 & K. Igor & 18 & średni & Ś. Dariusz & 24 & wysoki \\
\hline 18 & Ś. Wiktor & 20 & średni & J. Mateusz & 26 & wysoki \\
\hline 19 & P. Kacper & 18 & średni & J. Antoni & 25 & wysoki \\
\hline 20 & T. Igor & 17 & średni & S. Mateusz & 29 & wysoki \\
\hline 21 & S. Krzysztof & 21 & średni & K. Jakub & 30 & wysoki \\
\hline
\end{tabular}




\begin{tabular}{|c|c|c|c|c|c|c|}
\hline \multirow[b]{2}{*}{ Lp. } & \multicolumn{3}{|c|}{ GRUPA A } & \multicolumn{3}{|c|}{ GRUPA B } \\
\hline & $\begin{array}{c}\text { Kolejne badane } \\
\text { dziecko }\end{array}$ & Suma pkt & $\begin{array}{c}\text { Poziom języka } \\
\text { twórczego }\end{array}$ & $\begin{array}{c}\text { Kolejne badane } \\
\text { dziecko }\end{array}$ & Suma pkt & $\begin{array}{c}\text { Poziom języka } \\
\text { twórczego }\end{array}$ \\
\hline 22 & T. Dawid & 12 & niski & L. Dawid & 26 & wysoki \\
\hline 23 & W. Mikołaj & 11 & niski & M. Stanisław & 25 & wysoki \\
\hline 24 & W. Dawid & 12 & niski & P. Borys & 27 & wysoki \\
\hline 25 & W. Mateusz & 11 & niski & P. Igor & 29 & wysoki \\
\hline 26 & K. Igor & 11 & niski & S. Antoni & 30 & wysoki \\
\hline 27 & D. Nikodem & 12 & niski & G. Filip & 31 & wysoki \\
\hline 28 & T. Mikołaj & 17 & średni & S. Antoni & 22 & średni \\
\hline 29 & S. Nikodem & 12 & niski & G. Bartosz & 20 & średni \\
\hline 30 & T. Kuba & 18 & średni & M. Aleksander & 21 & średni \\
\hline
\end{tabular}

Źródło: badania własne.

W zakresie twórczości leksykalnej za odmianę wyrazów dzieci mogły otrzymać 1 pkt. W grupie A 18 dzieci uzyskało po 1 pkt. Natomiast 12 dzieci nie otrzymało żadnych punktów. Zupełnie inaczej przedstawia się punktacja w grupie B: wszystkie dzieci otrzymały punkty za twórczość leksykalną: 11 dzieci po 2 pkt, 13 dzieci - po 3 pkt, natomiast po 4 pkt uzyskało 6 dzieci.

W zakresie twórczości semantycznej między grupą A i B również przedstawiała się duża różnica. Badaniu podlegały wypowiedzi dzieci, w których użyte były neologizmy, zdrobnienia i zgrubienia, epitety, porównania, hiperbole, animizacje, personifikacje, alegorie i symbole. Za brak takiego środka dziecko otrzymywało podczas wypowiedzi 0 pkt, natomiast za każdy użyty środek - 1 pkt. W grupie A tylko 1 dziecko otrzymało 4 pkt, 3 dzieci - po 3 pkt, 6 dzieci - po 2 pkt, 10 dzieci - po 1 pkt. Natomiast 10 dzieci nie uzyskało żadnej punktacji. W grupie B odpowiedzi 11 dzieci oceniono po 2 pkt, 14 dzieci - po 3 pkt i 5 dzieci - po 4 pkt. Żadne dziecko z tej grupy nie otrzymało 0 pkt z zakresu twórczości leksykalnej.

W wypowiedziach dzieci dokonano także oceny, użytych przez nie inwersji, elips, powtórzeń, paralelizmów i anafor, pytań retorycznych z zakresu twórczości syntaktycznej. Za brak takiego środka dziecko otrzymywało podczas wypowiedzi 0 pkt, natomiast za każdy użyty środek - 1 pkt. W grupie A dzieci uzyskały bardzo mało punktów za twórczość semantyczną: 1 dziecko zdobyło 3 pkt, 1 dziecko - 2 pkt i 1 dziecko - 1 pkt. Pozostałe 27 osób nie otrzymało żadnych punktów. W grupie B sytuacja przedstawiała się odmiennie. Tutaj 3 dzieci oceniono na 4 pkt, 15 dzieci 3 pkt i 10 dzieci - 1 pkt.

Analiza wypowiedzi dzieci w zakresie twórczości tekstowej też nie przedstawia się najlepiej. W grupie A wprawdzie punktacja nieznacznie wzrosła, jednak poziom języka twórczego przedszkolaków pozostał na tym samym poziomie. Dzieci rzadko otrzymywały maksymalną liczbę punktów. W zakresie fabularyzacji wypowiedzi (aneks 3 i 4, tabele 3 i 4, punkt IV.1 a) dzieci najczęściej otrzymywały po 1 pkt: w grupie A - 10 dzieci, a w grupie B - 13 dzieci. 
Dzieci, wypowiadając się na temat obrazków, używały prostych zdań, nazywając czynności, jakie zwierzęta wykonują na obrazkach, posługując się pojedynczymi wyrazami lub równoważnikami zdań (IV.1 b).

Wypowiadały się pełnymi zdaniami, ale były to zdania izolowane. Te dzieci otrzymały za swoje wypowiedzi po 2 pkt, w grupie A było ich 13, w grupie B - 13. Tylko u 6 dzieci z grupy A i 17 dzieci z grupy B zaobserwowano zwięzłą i logiczną składnię, co w pełni zapewniało jednoznaczny odbiór treści komunikatu. Dzieci te otrzymały po 3 punkty. Oceniano także wypowiedzi spójne i wartkie (IV.1 d) na 4 pkt. W grupie A tylko 1 dziecko otrzymało maksymalną liczbę punktów. Był to przedszkolak, który odznaczał się wysokim poziomem języka twórczego. Natomiast w grupie B żadne dziecko nie uzyskało 4 pkt.

Dzieci potrafiły przedstawić swoje mieszkanie, określając kolor ścian, liczbę pokoi oraz sprzętów znajdujących się w pomieszczeniach. Żadne nie opisało swojego domu tak, by można było go sobie wyobrazić. Dzieci fragmentarycznie dobierały słownictwo, co nie pozwoliło na wnikliwe zorientowanie się w temacie i treści przekazywanych informacji. Dlatego też za wyczerpalność wypowiedzi otrzymywały tylko 1 pkt (IV.2 a). W grupie A było 1 takie dziecko, natomiast w grupie B żadne dziecko nie uzyskało 1 pkt, co oznacza, że dzieci te potrafiły wyczerpać swojej wypowiedzi.

Dzieci, które zwracały uwagę na kilka właściwości, elementów, cech zdarzeń w wypowiedzi, tylko częściowo pamiętały o istotnych elementach kontekstu (IV.2 b), nie uwzględniały wszystkich wątków wypowiedzi, otrzymywały po 2 pkt. W grupie A było to 14 dzieci, natomiast w grupie B - 9 dzieci.

Natomiast wypowiedzi, w których ujęto wszystkie elementy, wymieniono wszystkie cechy zdarzenia, charakteryzowały się trafnością i jednoznacznością oraz właściwie informowały o zdarzeniach następujących po sobie, oceniane były na 3 pkt (IV.2 c). W grupie A takich wypowiedzi udzieliło 12 dzieci, natomiast w grupie B - 19 dzieci.

Dzieci, które tworzyły w swojej wypowiedzi nowe linie narracji, wymyślając nowe sytuacje, otrzymywały 4 pkt (aneks 3 i 4, IV.2 d). W obu grupach taki wynik uzyskało 3 wychowanków.

Wszystkie zdarzenia opisywane przez dzieci przedstawione były w pełnym kontekście czasowym (IV.3 a, b, c, d). Użycie perspektywy czasowej pozwoliło na przyznanie punktacji. Za wypowiedź wyłącznie w czasie teraźniejszym - w grupie A 1 dziecko otrzymało 1 pkt, w grupie B - żadne dziecko nie uzyskało punktów. Za użycie częściowego kontekstu dzieci otrzymywały po 2 pkt: w grupie A - 14 dzieci, natomiast w grupie B -8 dzieci. Z kolei za umieszczenie przedstawionych zdarzeń w pełnym kontekście czasowym w grupie A przyznano po 3 pkt 10 dzieciom, w grupie B - 21 dzieciom.

Dzieci, które potrafiły umieścić przedstawione zdarzenia w pełnym kontekście czasowym i podkreślały zmienność czasową opowiadanych wydarzeń punktowane były najwyżej. Tylko 2 dzieci w grupie A uzyskało za swoje wypowiedzi po 4 pkt, natomiast w grupie B - 1 dziecko. 
W zakresie ekspresji wypowiedzi ustnych (IV.4 a, b, c, d) dzieci również uzyskały niską ocenę. Za obiektywną i lakoniczną relację w grupie A przedszkolaki - 3 osoby - otrzymały po 1 pkt. W grupie B żadnemu dziecku nie przyznano 1 pkt. Punktacja tych dzieci była wyższa. Wypowiedzi, w których dzieci potrafiły przedstawić wydarzenia nie tylko z pozycji widza, ale również uczestnika, miały wartość 2 pkt. Otrzymały je 22 osoby z grupy A i 12 z grupy B. Dzieci, które potrafiły przedstawić zdarzenia na rysunku w kontekście własnych przeżyć, mogły uzyskać po 3 pkt. Zadanie to wykonało 5 dzieci z grupy A i 17 dzieci z grupy B. Natomiast za wypowiedzi odzwierciedlające osobisty udział dziecka w danej sytuacji komunikowania, jego rolę, postawę, pragnienia, sądy, zawierające porzekadła, powiedzenia można było otrzymać po 4 pkt. W grupie A żadne dziecko nie zostało ocenione na 4 pkt, natomiast w grupie B - jedno dziecko.

Również w zakresie emocjonalności (IV.5 a, b, c, d) wypowiedzi ustne dzieci otrzymały niski wynik. W lakoniczny sposób przekazywały treści zdarzeń bez zwracania uwagi na przeżycia bohaterów, mówiły o ich zewnętrznych cechach (wygląd, co robi), używając słów niezabarwionych emocjonalnie, które nie wpływały bezpośrednio na określone reakcje odbiorcy. Oceniane zostały na 1 pkt i otrzymało go 9 osób z grupy A, z grupy B nikt nie uzyskał 1 pkt.

Dzieci, które potrafiły określić stan emocjonalny bohaterów, używając słów nacechowanych emocjonalnie, mogły otrzymać za taką wypowiedź po 2 pkt. W grupie A było 18 takich dzieci, natomiast z grupy B - 10 dzieci.

Wśród badanych przedszkolaków znalazło się 3 dzieci z grupy A i 19 dzieci z grupy B, które otrzymały po 3 pkt (IV.5 c) za wypowiedzi odzwierciedlające sposób myślenia i wyrażania bohatera, potrafiące wyciągać własne wnioski i oceniające zdarzenia. Żadne z dzieci z grupy A nie otrzymało 4 pkt, które można było uzyskać za wyrażanie barwą i siłą głosu swoich emocji w związku z opowiadanym wydarzeniem. W grupie B 4 pkt za swoją wypowiedź otrzymało 1 dziecko.

Dzieci wypowiadały się ustnie w sposób oryginalny (IV.6 a, b, c, d). Wypowiedzi ich były poprawne, rzeczowe, ale schematyczne, wykorzystywały stereotypowe środki wyrazu oraz słownictwo powszechnie stosowane. Dlatego też w tym przypadku otrzymały najniższą punktację - 1 pkt. W grupie A było 10 takich dzieci, natomiast w grupie B - żadne dziecko nie uzyskało 1 pkt.

Za wypowiedzi poprawne, zabarwione emocjonalnie i za trafność doboru słownictwa 18 przedszkolaków z grupy A i 16 z grupy B otrzymało po 2 pkt. Dwoje dzieci z grupy A i 14 z grupy B potrafiło w takcie wypowiedzi fantazjować i używać rzadko spotykanych słów, za co otrzymały po 3 pkt. Żaden z badanych nie uzyskał 4 pkt, gdyż dzieci nie potrafiły wypowiadać się w poprawnej formie i stylu.

Również różną punktację wychowankowie otrzymali w zakresie złożoności wypowiedzi (IV.7 a, b, c, d). Czternaścioro dzieci z grupy A za wypowiedź monologową i prosty sposób przekazywania zdarzeń otrzymało po 1 pkt. Żaden respondent z grupy B nie uzyskał za złożoność wypowiedzi 1 pkt. Natomiast 10 dzieci z grupy 
A i 19 z grupy B prowadziło monolog z intuicyjnie wkomponowaną mową pozornie zależną, za co otrzymały po 2 pkt. Za złożoną wypowiedź, użycie zdań rozwiniętych i wielokrotnie złożonych przedszkolaki mogły otrzymać po 3 pkt. W grupie A było 6 takich dzieci, a w grupie B - 11 dzieci.

Nikt z obu grup nie uzyskał 4 pkt za wypowiedź z bogactwem środków składniowych. Testy twórczości językowej po eksperymencie udowodniły, że dzieci z grupy B bardzo rozwinęły swoje wypowiedzi. Prawie wszystkie badane osoby uzyskały poziom wysoki z zakresu języka twórczego. W grupie A dzieci otrzymały wprawdzie wyższą punktację, jednak nie podniosły swojego poziomu języka twórczego.

Analiza wyników pozwoliła na wysunięcie wniosku, że w wyniku przeprowadzonych zabaw twórczych u dzieci w grupie eksperymentalnej znacznie zwiększył się poziom języka twórczego. Na początku badania 19 dzieci wykazywało niski poziom rozwoju języka twórczego, tylko u 9 z nich można było stwierdzić poziom średni, a wysoki poziom języka twórczego wykazywało tylko 2 dzieci. Przeprowadzony test rozwoju języka twórczego na końcu badania wykazał, że w grupie eksperymentalnej aż 27 dzieci wykazuje wysoki poziom rozwoju języka twórczego, a tylko troje poziom średni, co świadczy o pozytywnym wpływie zabaw na rozwój tej sfery twórczości dzieci.

Natomiast w grupie kontrolnej język twórczy, którym posługiwały się dzieci, pozostał na końcu badania na takim samym poziomie. Wprawdzie zwiększyła się liczba punktów, jakie dzieci zdobywały na trzecim etapie badań, lecz poziom języka twórczego przedszkolaków z grupy A pozostał ten sam. Te dane przedstawiono na wykresie 1 .

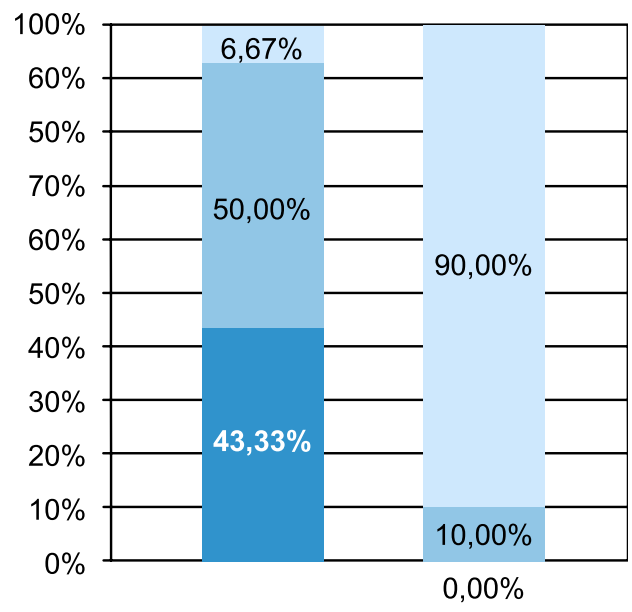

grupa A

grupa B niski

średni

wysoki

Wykres 1. Porównanie poziomu języka twórczego 5-latków z grupy A i B - eksperymentalnej na koniec badania 
W grupie B częściej można było zaobserwować poziom wysoki, natomiast w grupie A - poziom średni i niski. Widać wyraźnie, że między grupą A i B istnieje wyraźna różnica w poziomie rozwoju języka twórczego na korzyść grupy B.

\section{Bibliografia}

Bober-Pełzowska M., Rozwijanie mowy u uczniów klas niższych, Wydawnictwa Szkolne i Pedagogiczne, Warszawa 1983.

Demelowa G., Elementy logopedii, Wydawnictwa Szkole i Pedagogiczne, Warszawa 1987.

Elkonin D.B., Psychologia zabawy, przeł. L. Łoś,Wydawnictwa Szkolne i Pedagogiczne, Warszawa 1984.

Harwas-Napierała B., Trempała J., Psychologia rozwoju człowieka. Charakterystyka okresów życia człowieka, Wydawnictwo Naukowe PWN, Warszawa 2000.

Kubicka D., Twórcze działanie dziecka w sytuacji zabawowo-zadaniowej, Wydawnictwo Uniwersytetu Jagiellońskiego, Kraków 2003.

Okoń W., Zabawa a rzeczywistość, Wydawnictwa Szkolne i Pedagogiczne, Warszawa 1987.

Smith D.D., Pedagogika specjalna, t. 2, przeł. A.J. Korbel, Wydawnictwo Naukowe PWN, Warszawa 2009.

Truskolaska J., Osoba i zabawa, Wydawnictwo KUL, Lublin 2007.

\section{The influence of creative play on the development of spoken language in 5-year- old children}

Abstract: The article emphasizes the importance of creative games in the education of small children. Games perform many functions: upbringing, educational, diagnostic and therapeutic. Research carried out by the author confirms the belief that every teacher working with young children should pay special attention to ensure that each child can develop their creative potential through creative play, and at the same time develop their predisposition to communicate.

Keywords: fun, language, creativity, education, children

\footnotetext{
About the author: Katarzyna Miłek, Ph.D. is an adjunct at the Gniezno College of the Millennium. She defended her doctoral thesis in 2017 on the subject of "Children's creativity in preschool activities". Her interests include: general pedagogy, pre-school pedagogy, creativity pedagogy. In academic research, she focuses on: teacher's pedagogical creativity, talented and creative children, transformations in pre-school and early school education.
} 


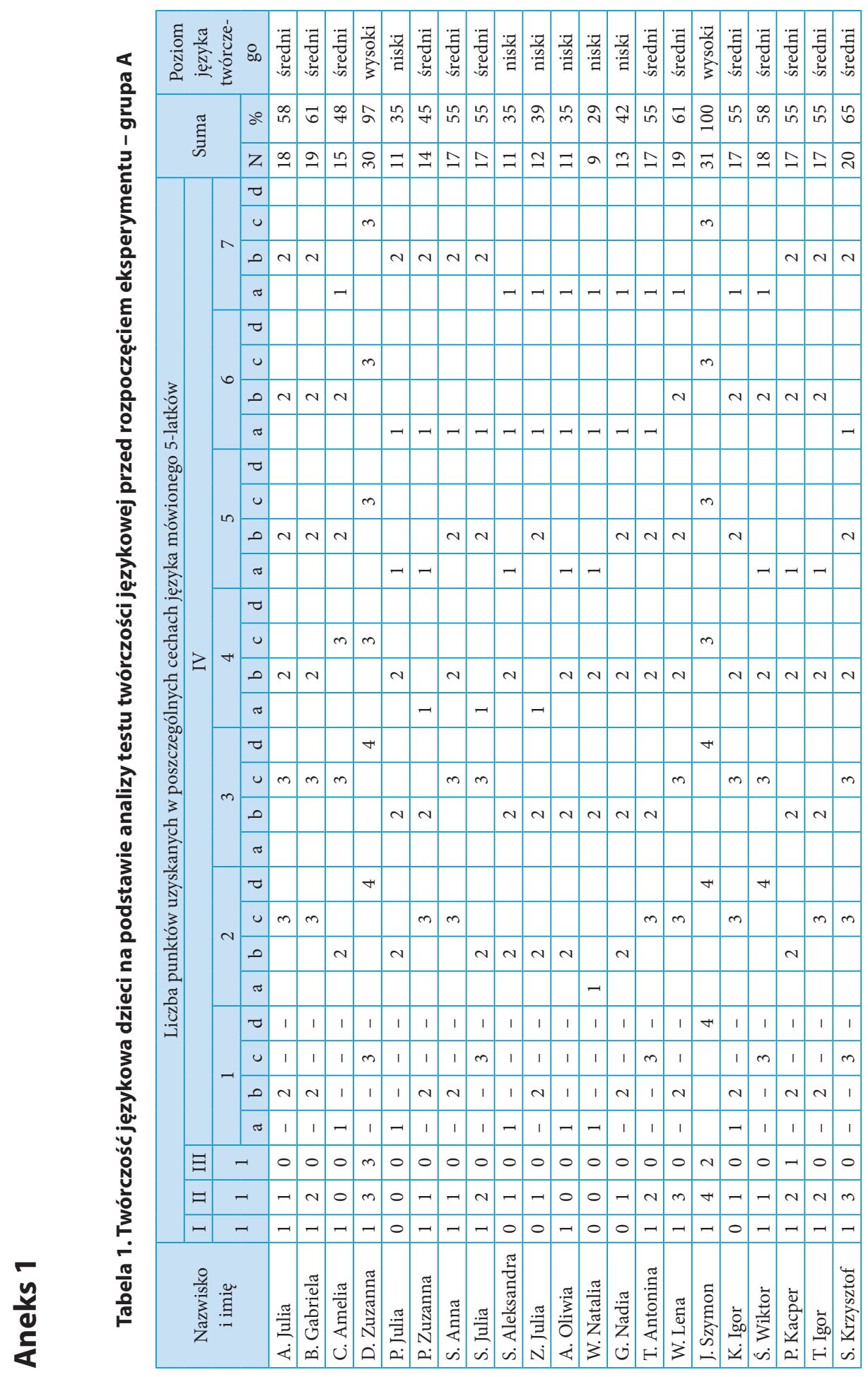



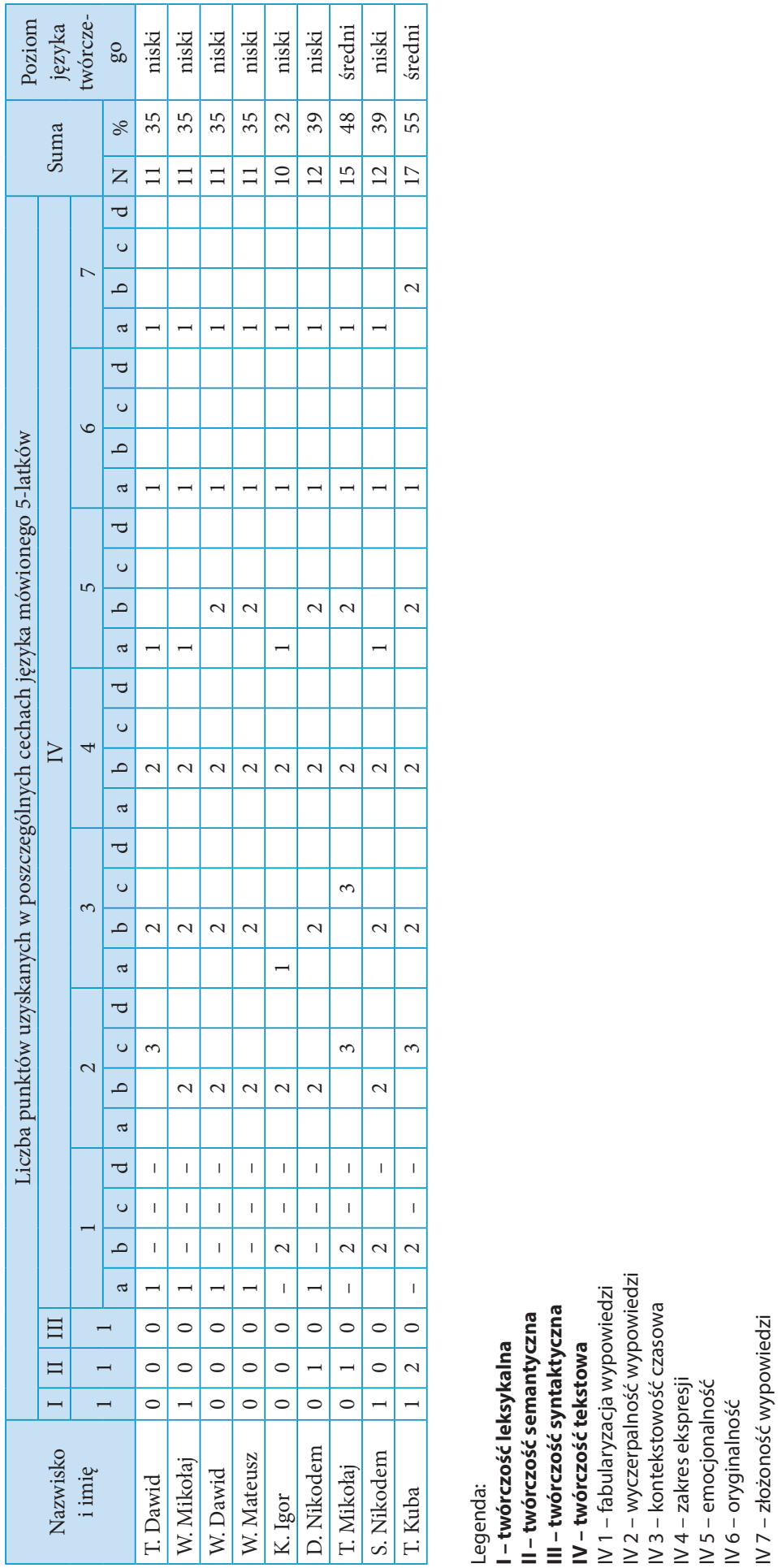


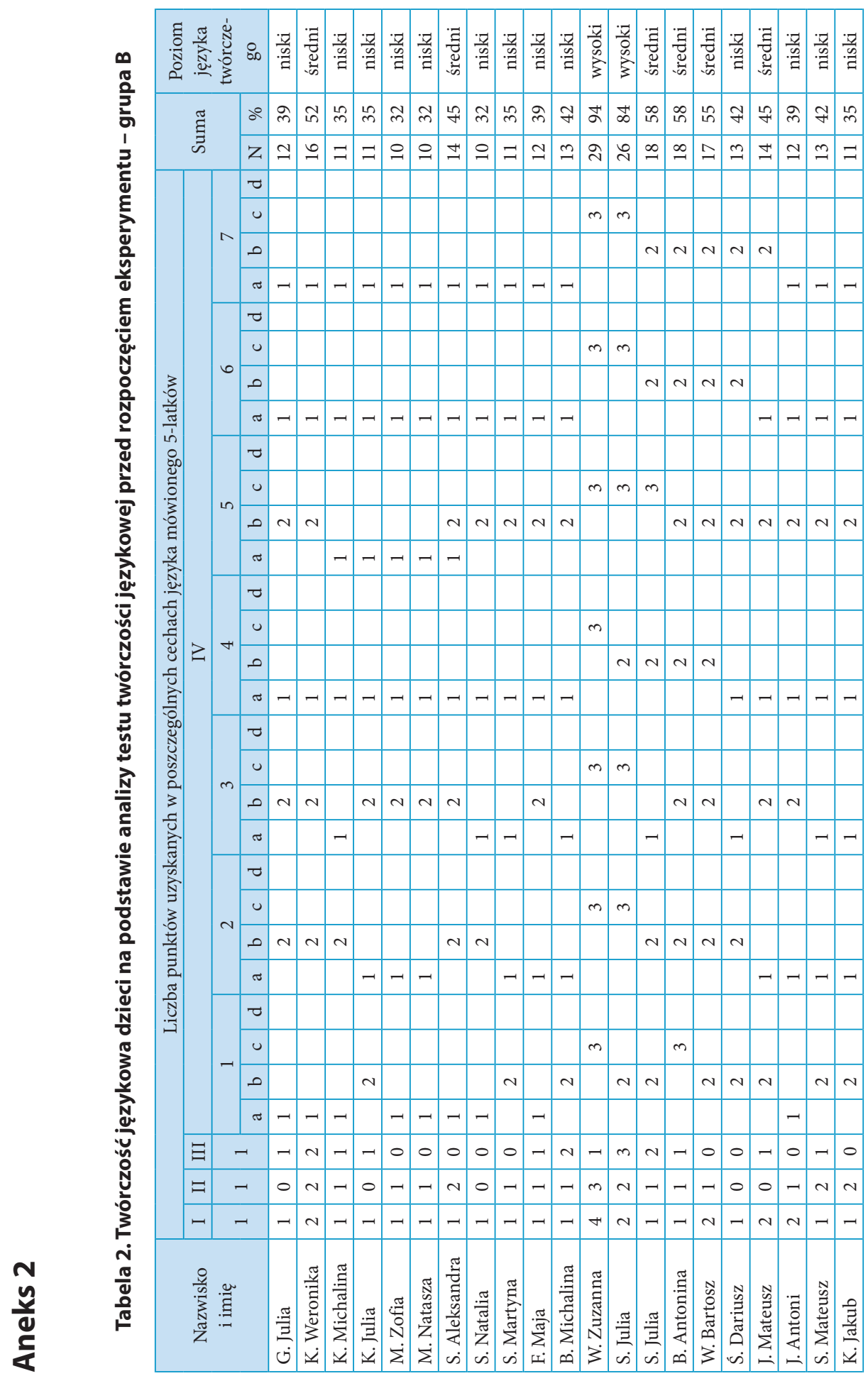



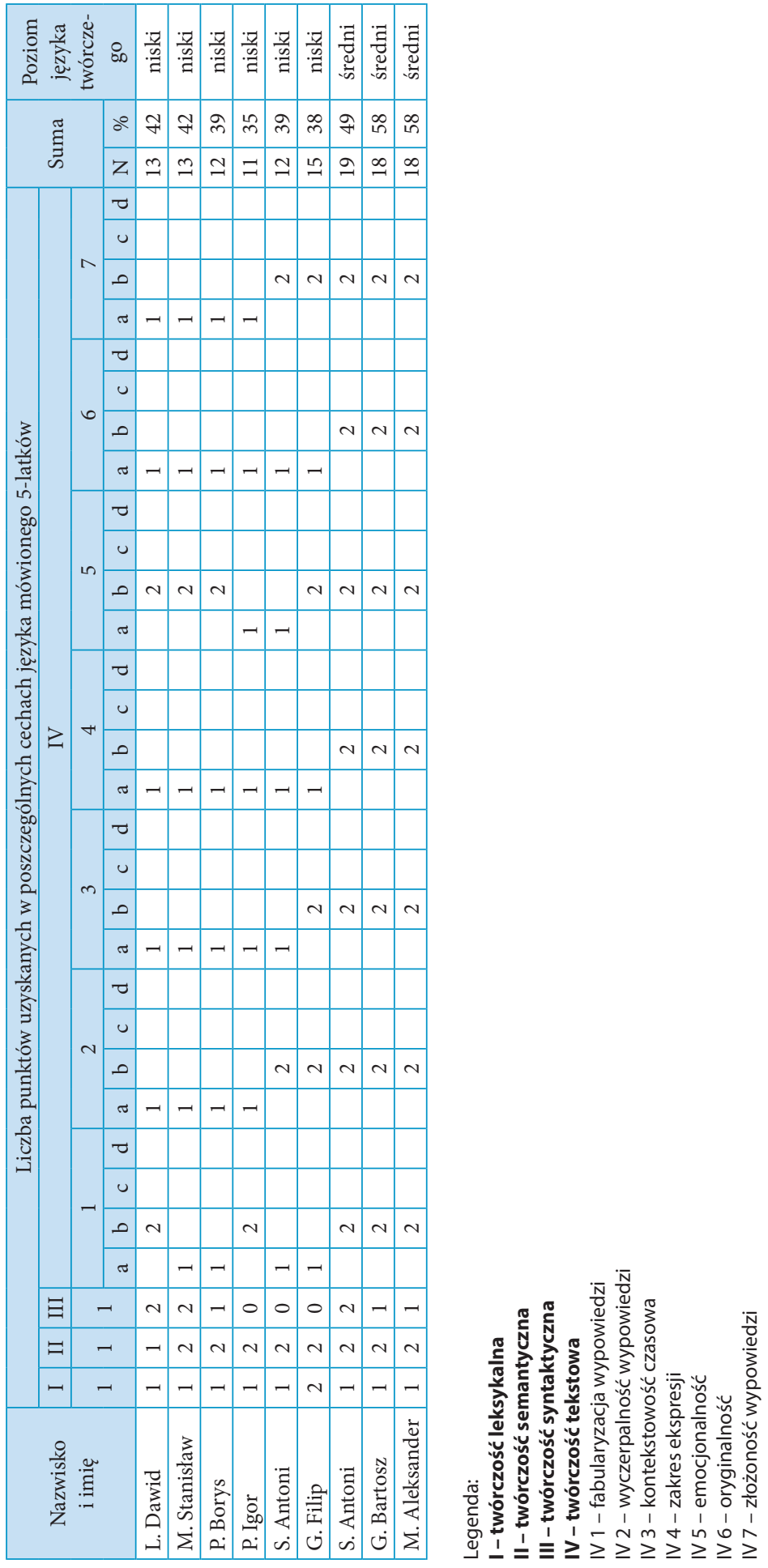


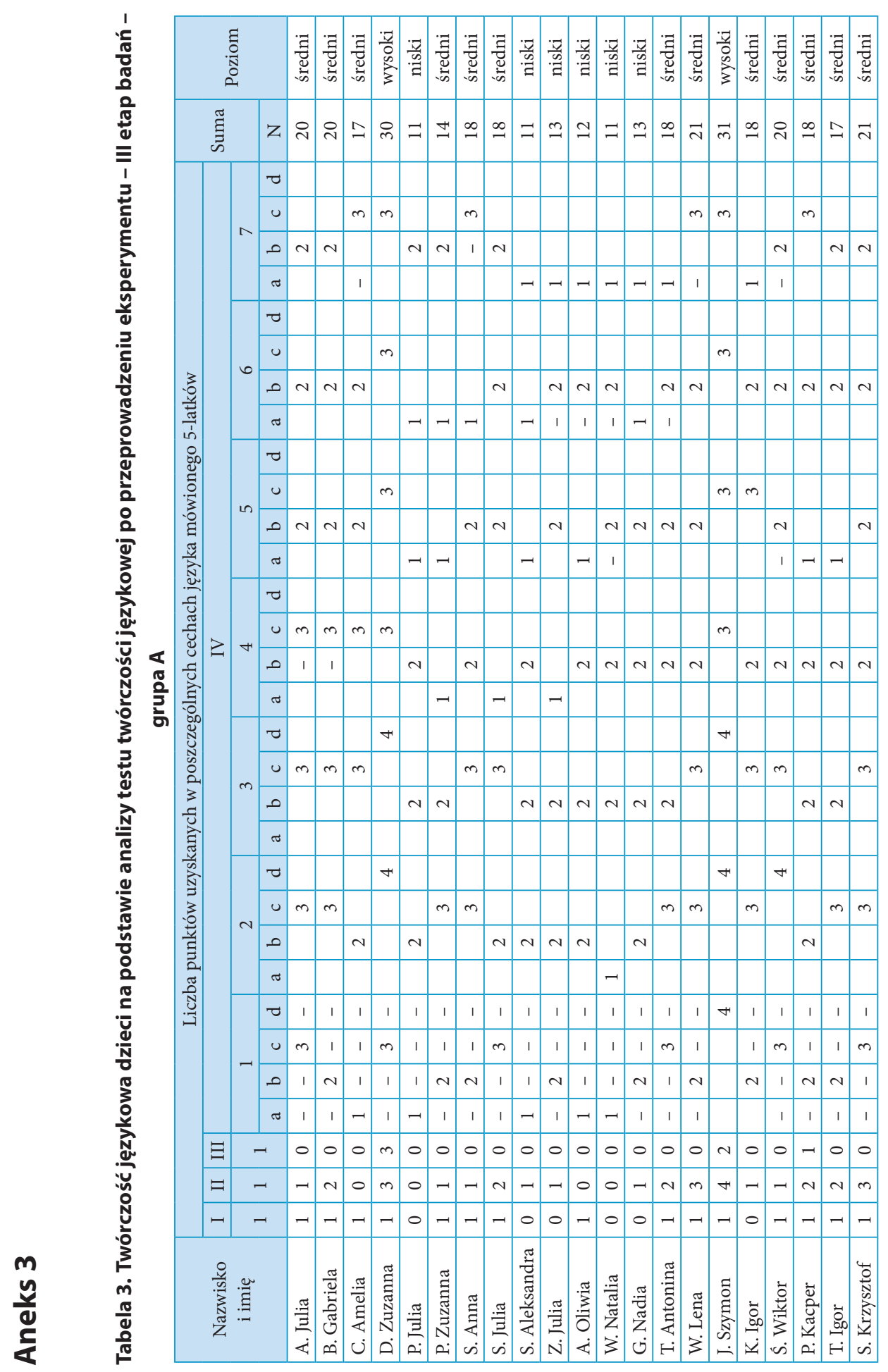



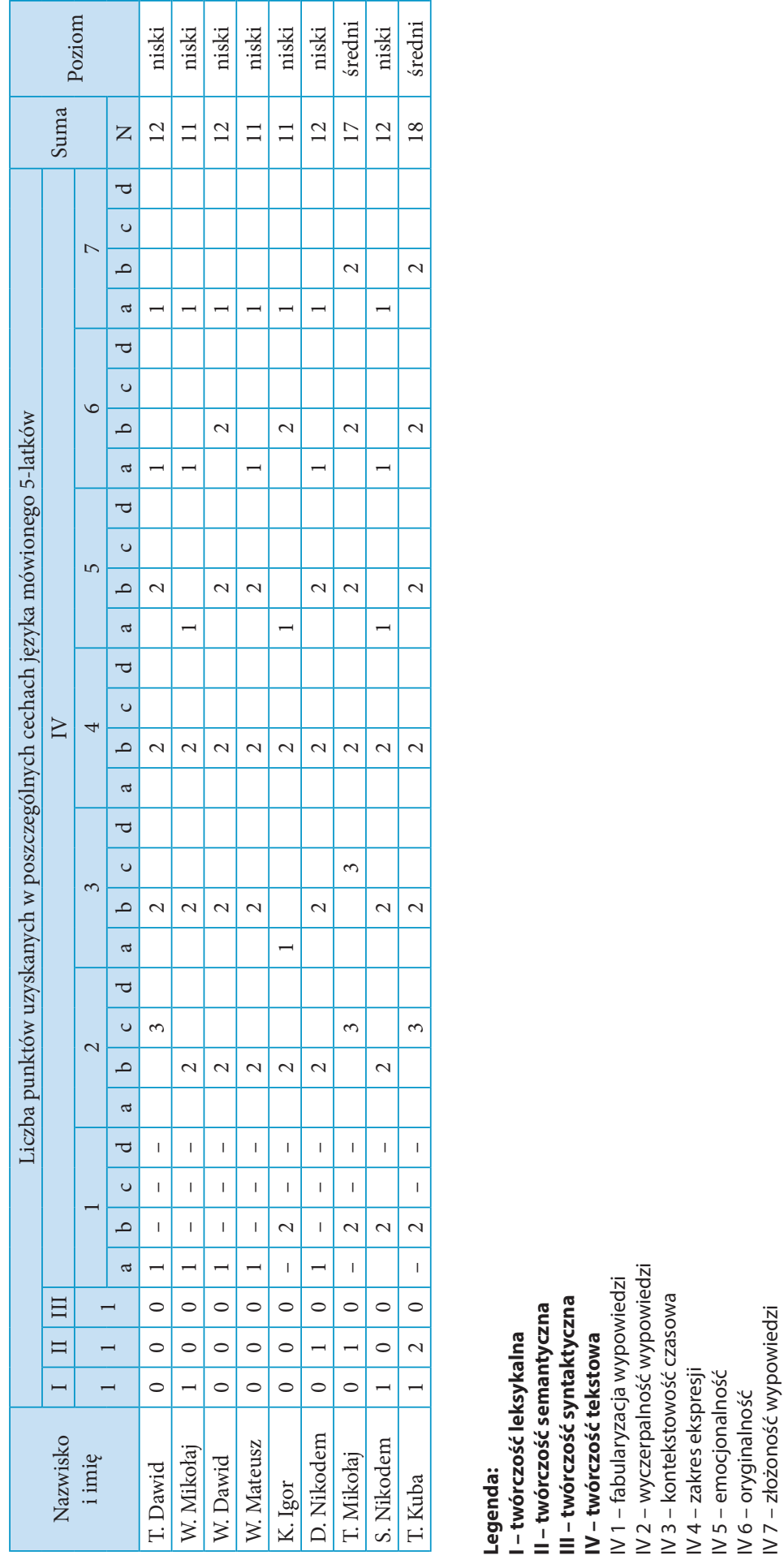


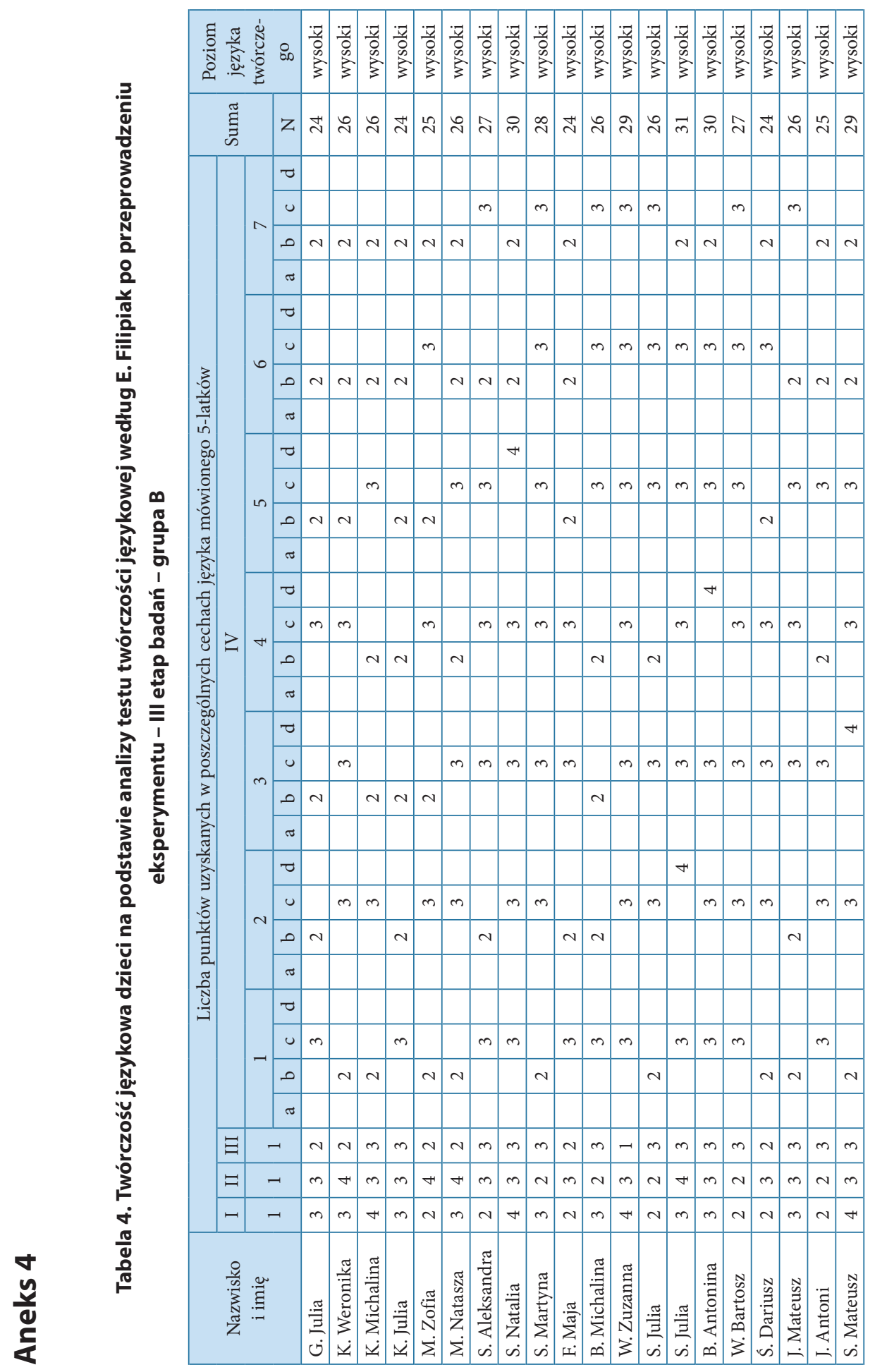



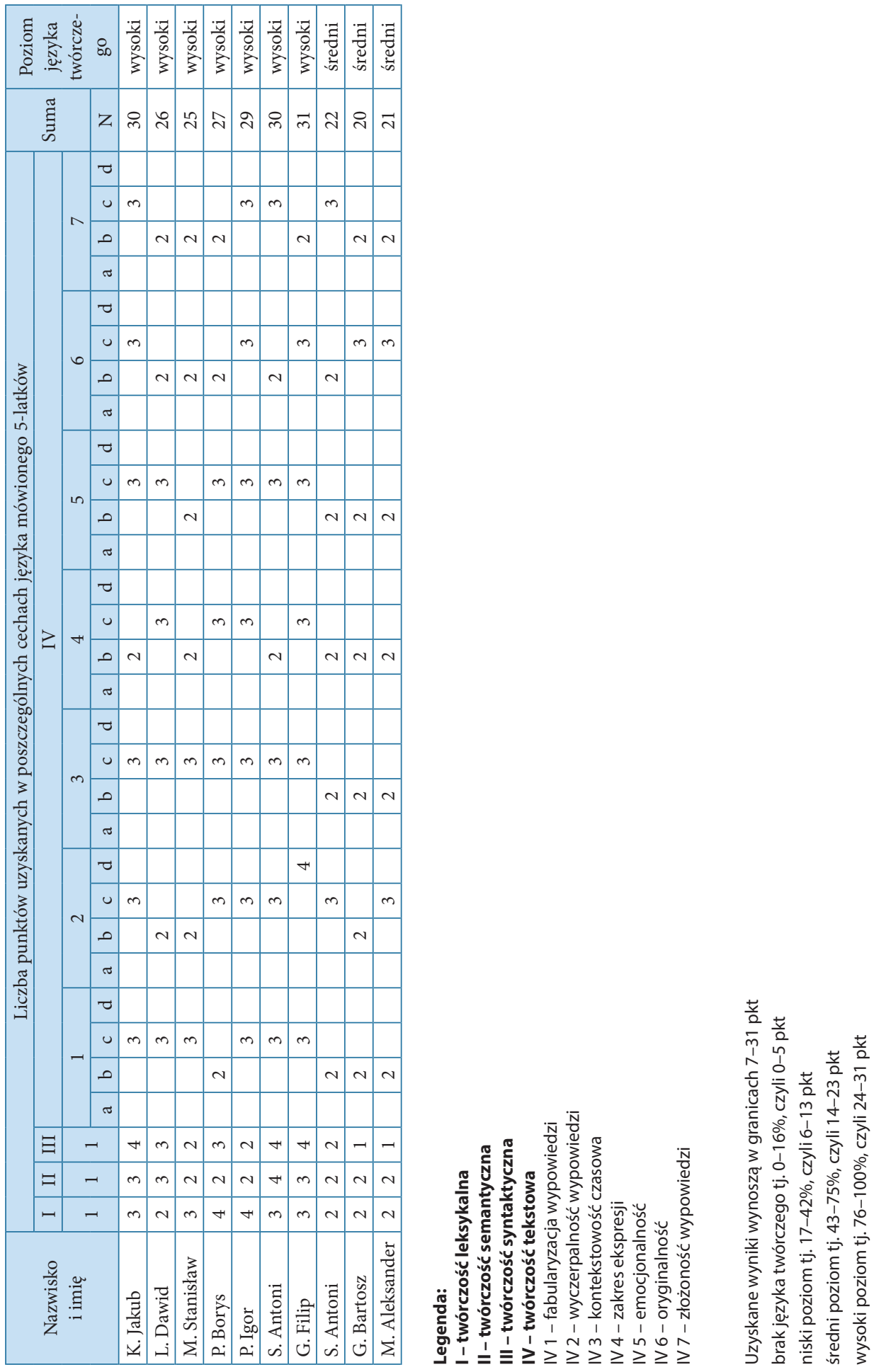
Natalia Bednarska* (iD https://orcid.org/0000-0002-7024-4671

Akademia Pedagogiki Specjalnej w Warszawie

https://doi.org/10.25312/2083-2923.17/2020_06nb

\title{
Budowanie strategii szkoły wobec prac domowych uczniów
}

\begin{abstract}
Streszczenie: W artykule została zebrana wiedza dydaktyczna i metodyczna na temat zadawania prac domowych, udokumentowana także wynikami badań empirycznych. Była ona punktem wyjścia do przedstawienia propozycji, jak dyrektor szkoły może budować strategię zadawania prac domowych dla szkoły.
\end{abstract}

Słowa kluczowe: praca domowa, metodyka zadawania pracy domowej, strategia szkoły wobec prac domowych

Praca domowa jest bardzo ważnym elementem procesu kształcenia. Niestety, jego potencjał dydaktyczny bywa często niedostrzegany i niedoceniany, a tym samym niewykorzystywany. Do nauczycielskiej metodyki zadawania pracy domowej wkrada się rutyna. Uczniowie skarżą się na przeciążenie pracami domowymi, które są często nudne, oparte na pamięciowym przyswojeniu wiedzy. To budzi frustrację wśród uczniów i ich rodziców. Prowadzi czasem do nadużyć takich jak korzystanie z portali internetowych, w których osoby trzecie odrabiają prace domowe za uczniów. Opinia publiczna coraz częściej zwraca uwagę na prace domowe uczniów, prowadzone są ożywione dyskusje na ten temat. Oto przykładowa wypowiedź jednego z rodziców: „Wiele rodzin znaczną część popołudnia spędza na przepychankach i dyskusjach związanych z zadaniami domowymi. «Dużo macie zadane?», «Tyle razy ci mówiłam, najpierw nauka, potem zabawa», «Lekcje odrobione?» - powtarzamy dzień po dniu.

"Natalia Bednarska - doktor nauk humanistycznych, adiunkt w Katedrze Małego Dziecka Instytutu Wspomagania Rozwoju Człowieka i Edukacji Akademii Pedagogiki Specjalnej w Warszawie, oligofrenopedagog, diagnosta i terapeuta pedagogiczny. Specjalizuje się w pracy z dziećmi i młodzieżą ze specjalnymi potrzebami edukacyjnymi. Zainteresowania badawcze koncentruje wokół problematyki uczenia się dzieci i młodzieży w świecie zdominowanym przez technologie cyfrowe. 
Marszczymy brwi i obgryzamy ołówki nad zadaniami z zeszytów ćwiczeń. Wolelibyśmy pojechać z dziećmi na wycieczkę rowerową, biologii uczyć w zoo albo wspólnie przygotować posiłek. Wszystkie te zajęcia sprzyjają nie tylko rozwojowi poznawczemu, ale i emocjonalnemu - pozwalają też wzmacniać rodzinne więzi. Szkoła rozpisała nam jednak inne zadania, a za niesubordynację grozi kara"'.

Z uwagi na powyższe dyrektor szkoły nie może lekceważyć kwestii pracy domowej. W swoim artykule przedstawiam zebraną wiedzę dydaktyczną oraz metodyczną na temat zadawania prac domowych, dokumentując ją także wybranymi wynikami badań naukowych. Artykuł kończy propozycja autorskiego planu opracowania wspomnianej w tytule artykułu strategii.

Określenie „praca domowa”2 odnosi się do zadań, które uczeń wykonuje po zakończeniu zajęć lekcyjnych, najczęściej w domu, z zachowaniem własnego tempa, metod i czasu realizacji ${ }^{3}$. Pracy domowej przypisuje się najczęściej następujące funkcje dydaktyczno-wychowawcze: wzbogacenie wiedzy deklaratywnej, proceduralnej i kontekstowej ucznia, uczenie umiejętności rozwiązywania problemów, kształtowanie postaw twórczych, rozwijanie zdolności uczenia się, budowanie poczucia odpowiedzialności i samodzielności uczniów ${ }^{4}$.

Duże zapotrzebowanie społeczne na rozmowę na temat pracy domowej ze strony rodziców i uczniów skutkuje tym, że nauczyciele i dyrektorzy szkół zastanawiają się, czy wprowadzić i jakie nowe rozwiązania metodyczne i organizacyjne w tej sferze. Szeroko ostatnio dyskutowaną w mediach zmianą organizacyjną jest likwidacja prac domowych. Inicjatywy tego rodzaju rozwiązania nie są wcale nowe. Choć ożywiona dyskusja na ten temat wróciła parę lat temu za sprawą ogłoszenia nielegalności prac domowych przez Krzysztofa Olędzkiego (Rzecznika Praw Ucznia i Rodzica), to pierwsze takie głosy pojawiły się już w pierwszej połowie XX wieku. Postulaty zaprzestania zadawania pracy domowej wysuwane są także w innych krajach. We Francji za sprawą Fédération des Conseils de Parents, FCPE (Federacja Rodziców Dzieci Szkolnych). Znanym krytykiem pracy domowej jest między innymi Alfie Kohn, autor książki The Homework Myth .

Zanim dyrektor placówki podejmie decyzję o zakazie lub ograniczeniu zadawania prac domowych lub będzie zachęcał swych nauczycieli do zmian metodycznych

${ }^{1}$ M. Stańczyk, Czy praca domowa rzeczywiście służy naszym dzieciom? Naukowcy to sprawdzili, 2014, http://coaching.focus.pl/zycie/rodzice-do-lekcji-542 [dostęp: 22.02.2020].

${ }^{2}$ W literaturze przedmiotu możemy się też spotkać z określeniami: „praca lekcyjno-domowa”, „praca międzylekcyjna”, „nauka domowa”, „, nauka własna”.

${ }^{3}$ A. Łukawska, Nauka domowa uczniów, uwagi kierowane do kandydatów na nauczycieli, „Nauczyciel i Szkoła" 2004, nr 1-2, s. 12.

${ }^{4}$ N. Bednarska, Praca domowa uczniów - przegląd badań, „Ruch Pedagogiczny” 2015, nr 4, s. 15.

${ }^{5}$ V. Baran, Zadawanie prac domowych jest nielegalne, 2007, http://wiadomosci.dziennik.pl/ wydarzenia/artykuly/66151,zadawanie-prac-domowych-jest-nielegalne.html [dostęp: 22.02.2020].

${ }^{6}$ A. Kohn, Homework Myth: Why Our Kids Get Too Much of the Bad Thing, Da Capo Press Books, Philadelphia 2006. 
(sposób, zakres zadawania prac domowych), powinien zapoznać się z refleksją naukową na temat prac domowych. Dyrektor placówki nie powinien podejmować decyzji w sprawie zadawania prac domowych przez nauczycieli w oderwaniu od wskazówek dydaktycznych i metodycznych oraz dostępnych wyników badań na ten temat. Dlatego kolejną część artykułu poświęcę na przedstawienie najważniejszych wskazówek dydaktycznych i metodycznych oraz przedstawię, jak zalecenia te powinny być wykorzystane podczas podejmowania decyzji w tej sprawie.

\section{Dydaktyczne i metodyczne wskazówki na temat pracy domowej}

Nawyków samodzielnej, efektywnej pracy w domu dzieci muszą uczyć się już od klasy zerowej i klasy pierwszej. Rodzic powinien zabezpieczyć środowisko pracy ucznia (odpowiednie miejsce do nauki, przybory do nauki, wybór czasu pracy). Uczeń, który rozpoczyna naukę w klasie pierwszej, ma 7 lat, a przed sobą 12 lub 17-18 lat nauki (razem ze studiami), dlatego przygotowanie odpowiednich warunków nauki jest sprawą niezwykle ważną. Początki systematycznego uczenia się w odpowiednich warunkach pozwalają na ukształtowanie właściwych nawyków w uczeniu się, ułatwiają kształtowanie obowiązkowości i samodzielności w codziennym spełnianiu obowiązków szkolnych. Planowanie pracy, pozyskiwanie informacji i opracowanie zgromadzonego materiału to podstawowe kompetencje, które powinno się rozwijać w klasach początkowych. Już od dziecka w pierwszej klasie możemy wymagać, aby starało się pamiętać, co jest zadane do domu, lub sprawdzało, co jest danego dnia do zrobienia, ustalało kolejność odrabiania lekcji, a także samodzielnie nad nimi pracowało. Do obowiązków małego ucznia należy także spakowanie tornistra na następny dzień. Dziecko powinno wiedzieć, że odrabianie pracy domowej jest jego obowiązkiem, a nie rodziców.

Jednak wdrażanie do samodzielności nie polega na pozostawieniu dziecka samego z zadaniami domowymi. Jeśli tego rodzaju obowiązki są w sferze aktualnego rozwoju ucznia, to jest on w stanie i powinien im samodzielnie sprostać. Zazwyczaj jednak zadania domowe leżą w obszarze najbliższego rozwoju dziecka i wtedy udział rodzica (tzw. kompetentnego dorosłego) jest niezbędny. Wrażliwe nauczanie, którego podejmuje się opiekun w tej sytuacji, jest przejściem od „cudzej pomocy do autopomocy”. Rodzic na początku przejmuje rolę eksperta, który wspiera, modeluje zachowanie dziecka, przekazuje wskazówki regulujące działanie itp., aby na końcu procesu tylko obserwować, jak ono samodzielnie odrabia pracę domową. Koncepcja konstruktywizmu społecznego odpowiada na pytanie, kiedy i w jaki sposób opiekun ma się angażować w pomoc w odrabianiu prac domowych.

Jeśli dziecko nie zostanie wdrożone do samodzielnego odrabiania prac domowych na etapie edukacji początkowej, będzie oczekiwało pomocy także w późniejszym wieku. Na podstawie badań sondażowych przeprowadzonych wśród 409 gim- 
nazjalistów Renata Kaczmarek stwierdziła, że $81 \%$ badanych uczniów charakteryzuje niski poziom samodzielności podczas odrabiania pracy domowej z języka polskiego, $17,5 \%$ badanych uczniów - średni, zaś tylko 1,5\% - wysoki. Uczniowie o wysokim poziomie samodzielności wykonanie pracy domowej poprzedzają planowaniem, a kończą sprawdzaniem jej. Średni poziom samodzielności cechuje się wykonaniem, któremu nie towarzyszy planowanie lub sprawdzanie. Uczniowie zakwalifikowani do ostatniej grupy wykonują pracę domową, pomijając jej planowanie i sprawdzanie. Autorka badania przyczyny niesamodzielności wiąże z nieumiejętnym organizowaniem pracy własnej ${ }^{7}$.

Mając na uwadze to, jak niezwykle ważne dla późniejszego procesu odrabiania prac domowych mają pierwsze lata nauki szkolnej, dyrektor szkoły powinien wprowadzić obowiązkowe spotkania rodziców, których dzieci rozpoczynają edukację w szkole, z nauczycielami lub specjalistami szkolnymi (pedagogiem, reedukatorem) na temat prac domowych. Wiemy, dzięki wynikom badań, że zaangażowanie rodziców ma duże znaczenie na początku edukacji dzieci, aktywność rodziców na tym polu silniej koreluje z wynikami w nauce uczniów w młodszym wieku szkolnym ${ }^{8}$. Uczestnicy spotkania powinni otrzymać pakiet informacji (najlepiej w formie ustnej i pisemnej). Tematyka powinna obejmować następujące zagadnienia:

1) interakcje rodziców z nauczycielem na temat pracy domowej (omówienie formy kontaktu rodzica $\mathrm{z}$ nauczycielem, ewentualnych terminów spotkań dla rodziców);

2) stwarzanie fizycznych warunków wykonywania pracy domowej (np. organizacja miejsca i czasu pracy, dostarczanie niezbędnych materiałów potrzebnych do ich wykonania, uwzględnienie pracy domowej w rodzinnym planie dnia);

3) systematyczny nadzór nad procesem odrabiania pracy domowej (obserwacja, które zadania sprawiają dzieciom trudność, co motywuje ich do wykonania zadań);

4) reagowanie na wykonanie zadania domowego (np. wzmacnianie i nagradzanie ucznia za ukończenie pracy domowej oraz poprawność wykonania czy wysiłek włożony w jej wykonanie, udzielanie wsparcia emocjonalnego podczas odrabiania pracy, przeglądanie i sprawdzanie poprawności wykonania pracy domowej);

5) udział rodziców w odrabianiu lekcji (ustalenie, kiedy i w jakiej formie (asystowanie, pomaganie, wspólne z uczniem odrabianie pracy domowej, uczenie własnych dzieci) rodzice mają brać udział w odrabianiu lekcji);

6) pomoc w wykorzystywaniu strategii uczenia się umożliwiających dopasowanie zadania do wiedzy i zdolności uczniów (zarządzanie kolejnością oraz czasem wykonania zadań domowych);

${ }^{7}$ R. Kaczmarek, Praca domowa a rozwój poznawczy uczniów gimnazjum, Politechnika Koszalińska, Koszalin 2014, s. 147-149.

${ }^{8}$ N. Bednarska, Praca domowa uczniów..., dz. cyt. 
7) ułatwianie uczniom zrozumienia zadań domowych (modelowanie lub demonstrowanie właściwych strategii uczenia się, tłumaczenie określonych partii materiału i sprawdzanie ich zrozumienia);

8) wspieranie uczniów w kształtowaniu strategii metapoznawczych (w nabywaniu umiejętności samoregulowanego uczenia się, kształtowanie osobistej odpowiedzialności za wykonanie pracy domowej i jej wynik, zachęcanie uczniów do samoobserwacji, nauka kontrolowania emocji związanych z wykonywaniem pracy domowej i inne) $)^{9}$.

Zaplanowanie i przeprowadzanie takiego spotkania jest niezwykle istotne dla dalszej edukacji dziecka, ponieważ model zaangażowania rodzica w proces odrabiania lekcji może określać wyniki w nauce ucznia. Wzbogacanie środowiska edukacyjnego dziecka przez wyposażenie jego miejsca nauki czy czytanie książek, odwiedziny teatrów, muzeów, bibliotek i innych instytucji pozytywnie koreluje z osiągnięciami szkolnymi. Natomiast ograniczanie autonomii uczniów przez bezpośrednią pomoc rodzica w odrabianiu lekcji, instruowanie oraz wywieranie nacisku przez sprawowanie silnej kontroli nad wykonaniem zadań odbijają się negatywnie na osiągnięciach uczniów ${ }^{10}$.

Kolejną ważną przesłanką dla dyrektora i nauczycieli, którymi on kieruje, jest stwierdzenie, że uczeń powinien mieć świadomość, jaki cel ma zadawana mu praca domowa. Wynika ona z jednej z zasad dydaktycznych. To, z jakim nakładem sił uczeń się uczy i jak organizuje wiadomości, zależy od stopnia rozumienia i uznania przez niego celu uczenia się $^{11}$. Uświadomienie sobie oraz zaakceptowanie celów przez ucznia aktywizuje go oraz uruchamia stany emocjonalne i wolicjonalne sprzyjające realizacji celów ${ }^{12}$. Prawdziwość tego stwierdzenia udowodniono także empirycznie. Janina Świrko-Pilipczuk przeprowadziła eksperyment pedagogiczny wśród 32 uczniów szóstej klasy. Na podstawie jego wyników stwierdziła, że uczniowie, którzy byli świadomi celów nauczania, osiągali lepsze wyniki w zadaniach sprawdzających umiejętność czytania, rozumienia czytanego tekstu oraz umiejętność redagowania wypowiedzi pisemnej. Znajomość celów wykonywanych prac domowych może nie tylko moty-

${ }^{9}$ Opracowano na podstawie: J.M.T. Walker, K.V. Hoover-Dempsey, D.R. Whetsel i C.L. Green, Parental Involvement in Homework: A Review of Current Research and its Implications for Teachers, After School Program Staff, and Parent Leader, Harvard Family Research Project, Cambridge M.A. 2004.

${ }_{10}$ N. Hill, D.F. Tyson, Parental Involvement in the Middle School: A Meta-Analytic Assessment of the Strategies That Promote Achievement, "Developmental Psychology" 2009, no 45; H. Cooper, J.J. Lindsay, B. Nye, Homework in the Home: How Student, Family and Parenting Style Differences Relate to the Homework Process, "Contemporary Educational Psychology" 2000, no 24 (4).

${ }^{11}$ K. Kruszewski, Najpotrzebniejsze zasady dydaktyczne, [w:] K. Kruszewski (red.), Sztuka nauczania. Czynności nauczyciela, Wydawnictwo Naukowe PWN, Warszawa 2004, s. 255.

${ }^{12}$ J. Świrko-Pilipczuk, Samodzielność uczniów, [w:] K. Denek, T.M. Zimny (red.), Edukacja jutra, V Tatrzańskie Seminarium Naukowe. Agencja Promocji Nauki i Kultury MENOS s.c., Częstochowa 1999, s. 103. 
wować uczniów do ich odrabiania, ale przełożyć się także na efektywność procesu uczenia się. Większego przyrostu wiedzy możemy się spodziewać u uczniów, których poinformujemy o celach i którym pozostawimy decyzję, jaką drogą mają dojść do ich realizacji. Podanie schematu, sposobu, wzoru na odrobienie pracy domowej nie służy konstruowaniu wiedzy ucznia. Tymczasem jest to powszechna praktyka nauczycieli, co potwierdzają wyniki badań przeprowadzone wśród gimnazjalistów ${ }^{13}$. Nauczyciele postępują tak, aby uchronić uczniów przed popełnianiem pomyłek i podejmowaniem nietrafnych prób rozwiązywania problemów. Jednak w tej sytuacji uczniowie nie mają możliwości samodzielnego zdefiniowania problemu, przewidywania jego rozwiązań, a w końcu także ewentualnego mierzenia się z konsekwencjami popełnionego błędnego wyboru ${ }^{14}$. Podawanie, a czasem narzucanie sposobu wykonania zadania domowego pozbawia uczniów doświadczania refleksji nad tym, co robią. Ograniczanie samodzielności poznawczej uczniów przejawia się także w praktyce podawania przez nauczycieli źródeł (w większości przypadków jest to podręcznik), z których uczniowie mają skorzystać podczas odrabiania pracy domowej. Przekaz podręcznikowy charakteryzuje się jednoznacznością terminologiczną, jest zogniskowany na wiedzy publicznej, przedstawia jedną wersję rozumienia świata, tym samym ogranicza uczniom możliwości przeżycia chaosu poznawczego, tak ważnego dla procesu konstruowaniu wiedzy ucznia.

Z powyższych rozważań wynika, że dyrektor powinien polecić nauczycielom, aby informowali uczniów, jaki jest cel zadania domowego. Cenniejsza poznawczo jest sytuacja, w której nauczyciel podaje cel zamiast określania, tłumaczenia, w jaki sposób go osiągnąć, czego uczniowie są nieświadomi. Spełnienie tych warunków wymaga od nauczyciela zmiany myślenia o pracy domowej. Zadania powinny wymagać kreatywnego myślenia, pozostawiać dzieciom więcej swobody w doborze materiałów. Podręcznik nie może być jednym źródłem informacji dla uczniów. Dydaktyczną wartość wykorzystywania podręczników i dołączonych do nich zeszytów ćwiczeń krytykowała m.in. Dorota Klus-Stańska:

Obszar wolności ucznia został w nich już nie zredukowany, ale wytrzebiony. Dziecko kluczy wzdłuż narysowanych strzałek, okienek i luk na podobieństwo szczura tresowanego przez behawiorystycznego entuzjastę [...]. Brak akceptacji dzieci, ich cech, temperamentów, woli, ich mądrości i doświadczeń życiowych powoduje, że treści dla nich przewidziane nie tworzą nadziei na codzienną ekspozycję konfliktów poznawczych, niezbędnych dla ożywienia aktywności własnej ${ }^{15}$.

${ }^{13}$ N. Bednarska, Aktywność gimnazjalistów w internecie a spostrzeganie pracy domowej, „Ruch Pedagogiczny" 2016, nr 4.

${ }^{14}$ D. Klus-Stańska, Behawiorystyczne źródła myślenia o nauczaniu, czyli siedem grzechów głównych wczesnej edukacji, [w:] D. Klus-Stańska, E. Szatan, D. Bronk (red.), Między schematem a poszukiwaniem nowych ujęć teoretyczno-badawczych, Wydawnictwo Uniwersytetu Gdańskiego, Gdańsk 2007.

15 Tamże, s. 24-25. 
Zadania wymagające kreatywności, samodzielności w doborze źródeł (także tych internetowych) są mniej nudne, bardziej motywujące dla dzieci. Motywacja do wykonania zadania domowego wzrasta, jeśli uczeń ma poczucie, że decyzja o postawieniu zadania, jego treściach oraz warunkach jego wykonania zależą od niego. Zasada ta oznacza, że uczeń powinien mieć nie tylko świadomość tego, po co wykonuje daną czynność, lecz także może partycypować w procesie stawiania tych celów pracy domowej, co daje mu przeświadczenie, że odrabianie lekcji może być przydatne.

Zadając pracę domową, nauczyciele powinni odnosić się do tego, co uczniowi jest bliskie (zainteresowania, aktualne wydarzenia). „O wartości kształcenia decyduje to, czy zainteresowania zostaną uszanowane i wykorzystane należycie [...]. Choć zainteresowania dzieci i cele programowe nauczycieli rzadko zazębiają się idealnie, to twórczy, autonomiczny nauczyciel potrafi znaleźć sposób, który pozwoli uczniom zrealizować zarówno ich własne zainteresowania, jak i jego cele"16. Praca domowa stwarza warunki do realizacji powyższego postulatu. Może być okazją do rozwijania własnych zainteresowań i dzielenia się nimi z innymi uczniami. Nauczyciele, którzy są zobligowani do realizacji programu nauczania, rzadko mają czas na komentowanie aktualnych wydarzeń życia społecznego. Tym samym dzielą świat uczniów na życie szkolne (sztuczne, oddalone od rzeczywistości) oraz pozaszkolne (to prawdziwe). Tej dwoistości nauczyciele mogą zapobiegać dzięki odwoływaniu się w pracach domowych do wydarzeń z życia codziennego dzieci.

Dzięki temu, że treści prac domowych łatwiej poddają się indywidualizacji, nauczyciele mogą uwzględniać w nich zainteresowania uczniów oraz aktualne wydarzenia. „Warunki pracy domowej są inne [...] i one właśnie bardzo sprzyjają wykorzystywaniu indywidualności uczniów i prędzej w tych warunkach może być uwzględniona praca twórcza ucznia, aniżeli na lekcjach"17. Indywidualizacja służy jednak przede wszystkim temu, aby dostosowywać treści prac domowych do wiedzy uprzedniej uczniów oraz ich możliwości poznawczych. Zadania zbyt łatwe oraz zbyt trudne działają demotywująco na uczniów. Indywidualizacja prac domowych wspomaga też proces uczenia się dzieci z dysleksją, dyskalkulią bądź zaburzeniami koncentracji. Badania naukowe pokazują, że pozytywnie wpływa na efektywność wykonania zadań domowych, kiedy w procesie indywidualizacji bierze udział sam uczeń, wybierając zadania, które wykona samodzielnie $\mathrm{w}$ domu ${ }^{18}$. Dyrektor szkoły powinien uczulać swój personel na zagadnienie indywidualizacji, konieczność dostosowania wymagań

16 B.J. Wadsworth, Teoria Piageta: poznawczy i emocjonalny rozwój dziecka, przeł. M. Babiuch, WSiP, Warszawa 1998, s. 175.

17 R. Miller, Praca domowa ucznia, Wydawnictwo Naukowego Towarzystwa Pedagogicznego, Warszawa 1937, s. 25.

18 R. Reclik, Samodzielny wybór pracy domowej przejawem pełnomocności uczniów w kształceniu zintegrowanym, [w:] W. Puślecki (red.), Zintegrowana edukacja wczesnoszkolna w teorii $i$ praktyce, Wydawnictwo Uniwersytetu Opolskiego, Opole 2004. 
nie tylko do tych zdolniejszych, ale także tych uczniów ze specjalnymi potrzebami edukacyjnymi.

Trudności w odrabianiu lekcji wynikają często także ze zbyt dużej liczby zadań domowych. Na tego rodzaju przeciążenie obowiązkami szkolnymi skarżą się zarówno uczniowie, jak i rodzice. Nauczyciele często nie dostrzegają tego problemu. Badania Agnieszki Koniecznej wykazały, że zdaniem nauczycieli uczniowie spędzają zdecydowanie mniej czasu na odrabianiu lekcji, niż dzieje się to w rzeczywistości ${ }^{19}$. Trudno znaleźć w literaturze przedmiotu szczegółowe wskazanie, ile czasu dziecko powinno poświęcać na odrobienie pracy domowej. W Stanach Zjednoczonych wielu nauczycieli kieruje się tzw. zasadą 10 minut. Określa ona, że wyznaczając odpowiedni czas, jaki powinna zająć praca domowa uczniowi, należy 10 minut pomnożyć przez numer klasy. Według tego wzoru w pierwszej klasie dziecko powinno odrabiać prace domowe przez średnio 10 minut, zaś w trzeciej klasie - 30 minut $)^{20}$.

\section{Strategia szkoły wobec zadawania prac domowych}

Podejmowanie decyzji metodycznych czy organizacyjnych w odniesieniu do prac domowych musi być procesem, rezultatem współpracy dyrektora szkoły ze wszystkimi nauczycielami, a nie odgórnym rozporządzeniem dyrektora szkoły. Po pierwsze, dyrektor placówki musi zadać sobie pytanie, czy istnieje potrzeba, żeby szkoła opracowywała strategię zadawania pracy domowej? Jeśli padanie odpowiedź twierdząca, dyrektor wraz z Radą Pedagogiczną musi znaleźć odpowiedzi na kolejne pytania:

1. Czy szkoła potrzebuje jednolitej strategii wobec pracy domowej, odnoszącej się do wszystkich przedmiotów?

2. Czy szkoła powinna opracować oddzielne strategie wobec pracy domowej dla różnych poziomów kształcenia?

3. Czy szkoła powinna opracować oddzielne strategie wobec pracy domowej dla każdego przedmiotu lub dla określonych bloków przedmiotów (np. humanistycznych, matematyczno-przyrodniczych)?

W tym miejscu chciałabym nadmienić, że w moim zamyśle strategia, o której piszę, nie powinna być kolejnym dokumentem, który ściśle reguluje lub nawet ogranicza realizowanie zamierzeń dydaktycznych nauczyciela, lecz raczej swego rodzaju zestawem zasad, do których dyrektor szkoły i nauczyciele mogą się odwołać. O szczegółowości wspomnianej strategii decydują sami nauczyciele w procesie jej tworzenia. Przedstawię, według jakich etapów mógłby przebiegać proces opracowania strategii wobec zadawania pracy domowej.

19 A. Konieczna, Czas przeznaczany na nauke $w$ domu - w opinii nauczycieli, uczniów i rodziców, „Ruch Pedagogiczny” 2011, nr 5-6, s. 49.

${ }^{20}$ N. Bednarska, Przekonania studentów na temat prac domowych uczniów klas początkowych, „Ruch Pedagogiczny” 2016, nr 1. 
1. Dyrektor na Radzie Pedagogicznej uzasadnia potrzebę wypracowania strategii szkoły wobec zadawania prac domowych.

2. Warsztaty z nauczycielami: zadaniem każdego nauczyciela jest zapisanie przykładowej pracy domowej, którą ostatnio zadał ze swojego przedmiotu. Następnie dyrektor lub prowadzący szkolenie specjalista (np. pedagog, psycholog) przedstawia funkcje, jakie powinna spełniać praca domowa. Zadaniem nauczyciela jest zastanowić się, którą z tych założonych funkcji spełnia ostatnio zadana przez niego praca domowa. Ćwiczenie to ma zainspirować do autorefleksji nauczycielskiej. Nauczyciele dzielą się z Radą Pedagogiczną rezultatem swoich przemyśleń. Jest to punkt wyjścia do dyskusji na temat prac domowych.

3. Skarbnica dobrych praktyk (1) - nauczyciele pracujący w szkole prezentują Radzie Pedagogicznej przykłady prac domowych, które w ich odczuciu były inspirujące dla uczniów, przyniosły dobry transfer wiedzy i kreatywne rozwiązania.

4. Skarbnica dobrych praktyk (2) - nauczyciele, podzieleni na zespoły, szukają w literaturze przedmiotu przykładów dobrych praktyk: zapoznają się między innymi z ideą tzw. lekcji odwróconej czy strategii nauczania wyprzedzającego S. Dylaka, czy z przykładami prac domowych zrealizowanych przy wykorzystaniu OZE (otwartych zasobów edukacyjnych).

5. Dyrektor lub szkolny specjalista przedstawia wyniki badań naukowych na temat prac domowych. Dyskusja.

5. Nauczyciele rozmawiają z uczniami, uczniowie opowiadają o tych pracach domowych, które - według nich - przyniosły najlepsze efekty, najbardziej im się podobały.

7. Nauczyciele rozmawiają z rodzicami o tym, co sprawia uczniom trudność w odrabianiu lekcji, co je motywuje do odrabiania lekcji.

8. Nauczyciele w zespołach opracowują własne strategie wobec zadawania prac domowych, potem dzielą się nimi z całą Radą Pedagogiczną. Dyskusja jest podstawą do wypracowania ostatecznej strategii szkoły wobec zadawania prac domowych.

Przedstawiony przeze mnie plan jest zaledwie zarysem, który można dowolnie zmieniać, upraszczać lub wzbogacać.

\section{Uwagi końcowe}

W swoim artykule podjęłam się przedstawienia wiedzy merytorycznej, dydaktycznej i metodycznej odnoszącej się do zagadnienia pracy domowej. Chciałam uzmysłowić, jak ważna jest rola tego rodzaju obowiązku w edukacji dziecka, pokazać, czym mogą kierować się dyrektorzy, kiedy będą rozmawiać o pracach domowych ze swoimi nauczycielami, uczniami oraz ich rodzicami. Nie w każdej szkole będzie potrzebne zbudowanie strategii wobec odrabiania lekcji, jednak w każdej użyteczny będzie namysł 
nad celem, efektywnością prac domowych, ich atrakcyjnością metodyczną. Każdy dyrektor szkoły poza wiedzą na temat prac domowych powinien też dowiedzieć się, w jaki sposób i ile prac domowych zadają pracujący w jego szkole nauczyciele. Powinien też mieć ukształtowane stanowisko na temat obowiązku odrabiania lekcji.

Zaproponowana przeze mnie strategia oraz jej proces opracowania mogą rodzić wiele pytań, a nawet wątpliwości. Mam nadzieję, że będą one punktem wyjścia do namysłu o pracach domowych, a może inspiracją do dyskusji na Radzie Pedagogicznej.

\section{Bibliografia}

Baran V., Zadawanie prac domowych jest nielegalne, 2007, http://wiadomosci.dziennik.pl/wydarzenia/artykuly/66151,zadawanie-prac-domowych-jest-nielegalne.html [dostęp: 22.02.2020].

Bednarska N., Aktywność gimnazjalistów w internecie a spostrzeganie pracy domowej, „Ruch Pedagogiczny” 2016, nr 4.

Bednarska N., Praca domowa uczniów - przegląd badań, „Ruch Pedagogiczny” 2015, nr 4.

Bednarska N., Przekonania studentów na temat prac domowych uczniów klas początkowych, „Ruch Pedagogiczny” 2016, nr 1.

Cooper H., Lindsay J.J., Nye B., Homework in the Home: How Student, Family and Parenting Style Differences Relate to the Homework Process, "Contemporary Educational Psychology" 2000, no 24 (4).

Hill N., Tyson D.F., Parental Involvement in the Middle School: A Meta-Analytic Assessment of the Strategies That Promote Achievement, "Developmental Psychology" 2009, no 45.

Kaczmarek R., Praca domowa a rozwój poznawczy uczniów gimnazjum, Politechnika Koszalińska, Koszalin 2014.

Klus-Stańska D., Behawiorystyczne źródła myślenia o nauczaniu, czyli siedem grzechów głównych wczesnej edukacji, [w:] D. Klus-Stańska, E. Szatan, D. Bronk (red.), Między schematem a poszukiwaniem nowych ujęć teoretyczno-badawczych, Wydawnictwo Uniwersytetu Gdańskiego, Gdańsk 2007.

Kohn A., Homework Myth: Why Our Kids Get Too Much of the Bad Thing, Da Capo Press Books, Philadelphia 2006.

Konieczna A., Czas przeznaczany na naukę $w$ domu - w opinii nauczycieli, uczniów i rodziców, „Ruch Pedagogiczny” 2011, nr 5-6.

Kruszewski K., Najpotrzebniejsze zasady dydaktyczne, [w:] K. Kruszewski (red.), Sztuka nauczania. Czynności nauczyciela, Wydawnictwo Naukowe PWN, Warszawa 2004.

Łukawska A., Nauka domowa uczniów, uwagi kierowane do kandydatów na nauczycieli, „Nauczyciel i Szkoła” 2004, nr 1-2. 
Miller R., Praca domowa ucznia, Wydawnictwo Naukowego Towarzystwa Pedagogicznego, Warszawa 1937.

Okoń W., Wprowadzenie do dydaktyki ogólnej, Wydawnictwo Akademickie „Żak”, Warszawa 2016.

Reclik R., Samodzielny wybór pracy domowej przejawem pełnomocności uczniów w kształceniu zintegrowanym, [w:] W. Puślecki (red.), Zintegrowana edukacja wczesnoszkolna w teorii i praktyce, Wydawnictwo Uniwersytetu Opolskiego, Opole 2004.

Stańczyk M., Czy praca domowa rzeczywiście służy naszym dzieciom? Naukowcy to sprawdzili 2014, http://coaching.focus.pl/zycie/rodzice-do-lekcji-542 [dostęp: 22.02.2020].

Świrko-Pilipczuk J., Samodzielność uczniów, [w:] K. Denek, T.M. Zimny (red.), Edukacja jutra, V Tatrzańskie Seminarium Naukowe. Agencja Promocji Nauki i Kultury MENOS s.c., Częstochowa 1999.

Wadsworth B.J., Teoria Piageta: poznawczy i emocjonalny rozwój dziecka, przeł. M. Babiuch, WSiP, Warszawa 1998.

Walker J.M.T., Hoover-Dempsey K.V., Whetsel D.R., Green C.L., Parental Involvement in Homework: A Review of Current Research and its Implications for Teachers, After School Program Staff, and Parent Leader, Harvard Family Research Project, Cambridge M.A. 2004.

\section{Building a school strategy for students' homework}

Abstract: The article gathers didactic and methodological knowledge about homework, and material from empirical research. It considers how the school head can build a homework strategy for a school.

Keywords: homework, homework methodology, school strategy for homework

\footnotetext{
About the author: Natalia Bednarska - Ph.D., works in the Department of Small Child Pedagogy at of the Institute of Assisted Human Development and Education at the Maria Grzegorzewska University in Warsaw, diagnostician and pedagogical therapist. She specializes in working with children and young people with special educational needs. Her research interests are focused on the issues of children and youth learning in a world dominated by digital technologies.
} 
Tobiasz Janikowski* (iD) https://orcid.org/0000-0002-3374-8571

Uniwersytet Pedagogiczny w Krakowie

https://doi.org/10.25312/2083-2923.17/2020_07tj

\title{
Indywidualizacja i „polifonizacja” nauczania języka obcego w szkole muzycznej
}

\begin{abstract}
Streszczenie: Środowisko muzyczne wymaga od nauczyciela języka obcego podjęcia wielu działań wykraczających poza standardowe założenia metodyczne. Niekonwencjonalny sposób kształtowania procesu dydaktycznego w szkole o profilu artystycznym wynika przede wszystkim z podwyższonego poziomu wrażliwości uczestników zajęć oraz niestandardowych oczekiwań stawianych nauczycielom. Z kolei uczniowie preferujący indywidualny sposób organizacji nauki wykazują znaczące zainteresowanie metodą bezpośrednią, nastawiając się przy tym - wzorem zajęć muzycznych - na ćwiczenie poręcznych i użytecznych schematów.
\end{abstract}

Słowa kluczowe: języki obce, metodyka nauczania, szkoły artystyczne, wielokanałowość procesów dydaktycznych, indywidualizacja

\section{Wprowadzenie}

Nauczanie języka obcego w szkole muzycznej w znaczący sposób różni się od organizacji zajęć w szkołach ogólnokształcących pozbawionych profilu artystycznego. Pierwszym aspektem, na który należy zwrócić uwagę - powołując się jednocześnie na opinię Moniki Jurewicz - jest okoliczność, iż uczniowie kształcący się muzycznie wykazują specyficzne zdolności oraz odmienne od swoich rówieśników potrze-

* Tobiasz Janikowski - dr, pracownik naukowo-dydaktyczny Katedry Historii i Kultury Krajów Niemieckiego Obszaru Językowego Uniwersytetu Pedagogicznego w Krakowie. W latach 20102017 nauczyciel języka niemieckiego w Państwowej Ogólnokształcącej Szkole Muzycznej II stopnia im. K. Szymanowskiego w Katowicach. Do jego zainteresowań badawczych należą: fenomen kulturowy polsko-niemieckiego pogranicza, problem tożsamości i identyfikacji zbiorowej mieszkańców obszarów wieloetnicznych, wpływ mediów cyfrowych na procesy dydaktyczne oraz przemiany społeczne i kulturowe. 
by rozwojowe. Zaspokajanie tych potrzeb, silniej niż w przypadku innych szkól, leży w kompetencjach naturalnego środowiska wychowawczego i intencjonalnego ${ }^{1}$.

Uczniów uczęszczających do szkoły muzycznej charakteryzuje często poczucie pewnej dystynkcji, czy wręcz elitarności, wynikające z przynależności do placówki edukacyjnej o nietypowym profilu kształcenia. Mimo to nie należy tracić z pola widzenia faktu, iż system szkolnictwa artystycznego w Polsce w zakresie tejże specjalności obejmuje stosunkowo rozległą sieć 506 szkół, w tym 282 szkół publicznych I i II stopnia, 216 szkół niepublicznych I i II stopnia oraz 8 akademii muzycznych ${ }^{2}$. Patrząc na całość z szerszej perspektywy, nietrudno dojść do przekonania, że zdobywanie wykształcenia w polskich placówkach prowadzących kształcenie muzyczne ma niewątpliwie charakter przywileju, a one same są unikatową wartością dodaną całego systemu szkolnictwa ${ }^{3}$.

\section{Nauczanie języków obcych w szkole muzycznej}

Przechodząc do tytułowej problematyki niniejszego artykułu - a zatem do zagadnień związanych z dydaktyką języków obcych w szkołach muzycznych - na wstępie zasadne wydaje się użycie kwantyfikatora zawężającego obszar podjętych analiz do szkół muzycznych oferujących naukę przedmiotów ogólnokształcących. Trzeba bowiem mieć na uwadze fakt, że duża część placówek kształcących muzycznie to szkoły popołudniowe, nieoferujące nauczania przedmiotów obowiązkowych w pierwszych trzech etapach edukacyjnych.

Gdy już mowa o organizacji procesu dydaktycznego, zasadne wydaje się poruszenie kwestii dostępności materiałów dydaktycznych i podręczników. Nie jest tajemnicą, iż na rynku wydawniczym do tej pory nie pojawił się odrębny, specjalistyczny podręcznik nauczania języków obcych, adresowany do uczniów szkół muzycznych I i II stopnia. Przyczyn takiego stanu rzeczy szukać należy przede wszystkim w przesłankach pragmatycznych: pomimo wspomnianej znaczącej liczby placówek prowadzących kształcenie muzyczne w Polsce jest ich mimo wszystko zdecydowanie za mało, aby zapewnić solidne, uzasadnione ekonomiczne podstawy do stworzenia „profilowanego” podręcznika, względnie bazowego kompendium materiałów po-

${ }^{1}$ Zob. M. Jurewicz, Instytucjonalne wspieranie rozwoju uczniów zdolnych muzycznie, [w:] W. Limont, J. Cieślikowska, J. Dreszer (red.), Osobowościowe i środowiskowe uwarunkowania rozwoju ucznia zdolnego, Wydawnictwo Naukowe Uniwersytetu Mikołaja Kopernika, Toruń 2010, s. 97.

${ }^{2}$ Zob. tamże, s. 98. W obliczu przywołanych powyżej danych statystycznych uzasadnione wydaje się postawienie pytania, czy jest to ilość wystarczająca dla szeroko rozumianego rozwoju kulturalnego państwa o niemalże 38-milionowej populacji. Zasadne wydaje się ponadto poruszenie kwestii, w jaki sposób silnie zinstytucjonalizowana forma kształcenia przyszłych zawodowych muzyków zaspokaja oddolne potrzeby społeczne.

${ }^{3}$ Nie sposób nie zauważyć, iż odpowiednik takiego systemu kształcenia nie występuje w wielu krajach Europy Zachodniej, legitymujących się wysokim poziomem kultury muzycznej. 
trzebnych podczas zajęć. Dotyczy to zarówno wiodącego języka angielskiego, który jak wiadomo - nauczany jest w szkołach podstawowych i średnich obligatoryjnie, jak również tzw. drugiego języka obcego (np. niemieckiego, francuskiego, włoskiego czy rosyjskiego), nauczanego w znacznie mniejszym wymiarze godzin, trafiającego do proporcjonalnie mniejszej liczby odbiorców. Brak poręcznego zbioru materiałów zawierających zestaw różnorodnych treściowo ćwiczeń językowych dla szkoły muzycznej stawia przed nauczycielem wyzwania organizacyjne o podwyższonym poziomie trudności. Musi on bowiem zdawać sobie sprawę z tego, że przygotowanie ambitnego i skutecznego planu dydaktycznego, dopasowanego do profilu szkoły, w dużej mierze uzależnione będzie od jego kompetencji, zaangażowania i kreatywności. Samo zaś rozszerzenie standardowego instrumentarium dydaktycznego w większości przypadków jawi się jako działanie konieczne, gdyż realizowanie i wprowadzanie w ramach nauczania języka obcego w szkole muzycznej jedynie „bazowych” treści programowych i merytorycznych, zawartych w standardowych podręcznikach stworzonych dla szkół nieprofilowanych, na dłuższą metę okazać się może nieskuteczne. W wielu przypadkach nie doprowadzi ono też zapewne do osiągnięcia spodziewanych, postawionych uprzednio celów dydaktycznych.

\section{Środowisko uczniowskie w szkole muzycznej}

Nauczyciel prowadzący zajęcia w szkole muzycznej znajduje się w środowisku, w którym - na co zwraca uwagę przywołana powyżej Monika Jurewicz - uczniom „o specjalnych potrzebach edukacyjnych stwarza się warunki do rozwoju specyficznych uzdolnień” ${ }^{4}$. Mamy zatem do czynienia z grupą indywidualności ukształtowanych, czy wręcz „sformatowanych” przez dość nietypowy profil zajęć dydaktycznych. Dodatkowo odbiorcami treści prezentowanych w ramach nauczania języka obcego są niemalże bez wyjątku - co nie pozostaje bez wpływu na skuteczność przyjętych strategii dydaktycznych - uczniowie obciążeni ponadprzeciętną ilością zajęć z przedmiotów ogólnokształcących i ogólnomuzycznych. Zdecydowana większość z nich zobligowana jest do intensywnego, indywidualnego rozwoju artystycznego w zakresie gry na instrumencie głównym, względnie nauki śpiewu. Z drugiej strony jest to środowisko, w którym tworzenie i percepcja sztuki traktowane są jako „szczególny przykład procesu komunikowania się - przekazywania informacji, poglądów, emocji i sposobu postrzegania świata między twórcą a odbiorcą oraz w gronie odbiorców między sobą"5.

Znajdujący się w tak różnorodnym i jednocześnie wymagającym środowisku różnorakich interakcji uczestnicy zajęć od samego początku podejmują naukę w ob-

${ }^{4}$ M. Jurewicz, dz. cyt., s. 97.

${ }^{5}$ M. Sasin, Kanon wykonawczy muzyki poważnej jako przestrzeń spotkania Innego, „Kultura i Wychowanie" 2018, nr 2, s. 126. 
rębie grupy rówieśniczej, którą cechuje duże rozwarstwienie kompetencyjne. W szkołach muzycznych już na początkowym etapie nauki dochodzi bowiem do widocznej wewnętrznej dyferencjacji: z jednej strony znaczącą część klasy stanowią uczniowie wykazujący wybitne zdolności muzyczne ${ }^{6}$, niemalże wyłącznie skoncentrowani na rozwijaniu swojej kariery artystycznej (a zatem poświęcający większość czasu grze na instrumencie, względnie rozwijaniu zdolności wokalnych), co automatycznie pozycjonuje ich poza obszarem uczestników zajęć zainteresowanych przedmiotami ogólnokształcącymi ${ }^{7}$. Rozwijając nieco powyższą myśl, należy zwrócić uwagę na prawidłowość, iż ponadprzeciętny talent muzyczny niejednokrotnie nie pociąga za sobą wyróżniających się zdolności w zakresie przedmiotów ogólnokształcących oraz szczególnej łatwości w przyswajaniu języków obcych.

Z drugiej strony stosunkowo liczną grupę uczestników lekcji języka obcego stanowią osoby wszechstronnie utalentowane ${ }^{8}$, posiadające cechy tzw. ucznia zdolnego, wyróżniającego się podzielnością uwagi, umiejętnością szybkiego rozwiązywania problemów czy wysokim poziomem inteligencji. W grupie tej uwidoczniają się dodatkowo inne cechy dystynktywne - na które wskazują Joanna Cieślikowska i Wiesława Limont - takie jak: „rozumowanie na wysokim poziomie złożoności i trudności, duże możliwości przyswajania nowych informacji, szybkość kojarzenia faktów, dobra pamięć, duża ciekawość intelektualna, logiczne myślenie, własny, specyficzny sposób uczenia się"

${ }^{6}$ Uzdolnienia muzyczne należy rozumieć przy tym jako „całokształt właściwości psychicznych, zarówno sensorycznych, intelektualnych, jak i emocjonalno-motywacyjnych oraz kinestetyczno-motorycznych, wyznaczających stosunek człowieka do muzyki i efektywność podejmowanych przez niego działań muzycznych”. M. Jurewicz, dz. cyt., s. 97-98.

7 Trudno oprzeć się wrażeniu, że swoiste zawężenie specjalizacyjne w szkole muzycznej postępuje wraz z osiąganiem kolejnych etapów nauki. Ewa Szatan, podając przykład Szkoły Muzycznej I i II stopnia im. F. Nowowiejskiego w Gdańsku, zauważa, iż w projektach, które uczniowie realizują dobrowolnie z nauczycielami przedmiotów ogólnokształcących „zaledwie około 30\% uczniów klas licealnych i aż około 84\% uczniów klas gimnazjalnych dostrzega możliwości rozwijania swoich pozamuzycznych zdolności. Może to świadczyć o sprecyzowanych - wyłącznie muzycznych - zainteresowaniach uczniów klas najstarszych". E. Szatan, Kształcenie ucznia zdolnego na przykładzie Ogólnokształcącej Szkoły Muzycznej I i II stopnia w Gdańsku, [w:] W. Limont, J. Cieślikowska (red.), Wybrane zagadnienia edukacji uczniów zdolnych, t. 1, Zdolności i stymulowanie ich rozwoju, Oficyna Wydawnicza „Impuls”, Kraków 2005, s. 307.

8 Osoby te można stosunkowo łatwo rozpoznać $i$ „wyselekcjonować” już na początkowym etapie nauki. Jak zauważa Monika Foryś: „Fakt, że uczniowie zdolni czasem wyraźnie demonstrują swoje zdolności w różnych kierunkach, ogromnie ułatwia ich identyfikację. Niekiedy bez większych trudności potrafimy zidentyfikować zdolności i uzdolnienia u dziecka - wskazuje na to jego wiedza, zachowanie, wytwory, wyniki testów”. M. Foryś, Diagnoza nauczycielska zdolności, [w:] M. Czarnocka, M. Foryś, K. Truś (red.), Rozpoznać, wspierać, rozwijać. Poradnia psychologiczno-pedagogiczna i szkoła a uczeń zdolny, Ośrodek Rozwoju Edukacji, Warszawa 2014, s. 16.

${ }^{9}$ J. Cieślikowska, W. Limont, Obraz ucznia zdolnego w potocznych koncepcjach nauczycieli, [w:] W. Limont, J. Cieślikowska, J. Dreszer (red.), Osobowościowe i środowiskowe uwarunkowania rozwoju ucznia zdolnego, Wydawnictwo Naukowe Uniwersytetu Mikołaja Kopernika, Toruń 2010, s. 22-23. 


\section{Indywidualizacja i „polifonizacja”"10 zajęć}

Jak zatem prowadzić lekcje języka obcego w środowisku, które z jednej strony jest tak silnie rozwarstwione kompetencyjnie, a z drugiej - wyraźnie ukształtowane przez wymagający, wielopłaszczyznowy model edukacyjny? Jaką strategię dydaktyczną przyjąć w obliczu wyraźnego zróżnicowania potencjalnych i realnych oczekiwań uczestników zajęć? Po pierwsze, nie należy tracić z pola widzenia okoliczności, iż uczniowie szkół muzycznych preferują tryb nauki indywidualnej i nierzadko dla takiej formy kontaktu z nauczycielem decydują się na naukę w szkole artystycznej ${ }^{11}$. Po drugie, wielu z nich szuka aktywności niekonwencjonalnych, nieszablonowych, koncepcyjnie wpisujących się w maksymę "think outside the box" ${ }^{12}$. Pokaźną grupę tworzą też niewątpliwie osobowości twórcze, dobrze czujące się w świecie sztuki i warunkach edukacyjnych wykraczających poza sztywne ramy dydaktyki szkolnej, mające wyraźną skłonność do twórczego przetwarzania rzeczywistości, wykazujące też nierzadko zaskakujące wręcz zdolności w obszarze szeroko rozumianej improwizacji ${ }^{13}$.

${ }^{10}$ Słowo "polifonizacja” jest terminem zaczerpniętym z teorii i historii muzyki, a odnosi się do zjawiska wielogłosowości. W niniejszym artykule chodzi przede wszystkim o wielowarstwowość i wieloaspektowość strategii dydaktycznych zastosowanych w ramach zajęć z języka obcego.

${ }^{11}$ Tezę tę potwierdzają rozważania Moniki Jurewicz: „Wspieranie rozwoju uczniów uzdolnionych muzycznie w środowisku szkolnym może przyjmować dwojaką formę: zajęć indywidualnych i zajęć grupowych. Ze względu na specyfikę kształcenia w szkołach artystycznych preferowaną formą kontaktów z uczniem są zajęcia indywidualne. Pozwalają one na specyficzny, niepowtarzalny kontakt z dzieckiem. Dają szansę na nawiązanie autentycznych, szczerych relacji z uczniem i jego najbliższymi. Pozwalają na wnikliwe monitorowanie na bieżąco postępów ucznia, motywowanie go do dalszej pracy, a w konsekwencji odpowiedzialne kierowanie jego rozwojem”. M. Jurewicz, dz. cyt., s. 105.

${ }_{12}$ Dobre rezultaty przynosi w tym ujęciu przeniesienie treści lekcyjnych do sfery różnorakich „pozaklasowych” interakcji. Spontaniczna prezentacja wiedzy, kompetencji, jak również materiałów przerobionych podczas zajęć lekcyjnych, odbywająca się na konkursach, akademiach, spotkaniach rocznicowych czy happeningach, powoduje nie tylko popularyzację treści językowych, lecz - w nie mniejszym stopniu - generuje w uczniach poczucie zadowolenia z osiągniętego sukcesu i wywołania pewnego rodzaju „echa medialnego”. Należy przy tym mieć na uwadze to, że uczniów szkół muzycznych uskrzydla i motywuje nade wszystko chęć nieskrępowanej prezentacji, publicznej autokreacji, po częstokroć również okazja do odbywającego się w duchu rywalizacji umacniania swojej pozycji w grupie. Stąd też nauczyciel języków obcych powinien - w miarę dostępności możliwości i środków - zadbać o okazje do jak najszerszej i jak najczęstszej zewnętrznej ekspozycji. Znakomicie sprawdzają się w tej funkcji wyjazdy i koncerty zagraniczne, na których uczniowie-muzycy zazwyczaj z dużą dozą młodzieńczego wigoru wykorzystują i eksponują swoje kompetencje muzyczno-językowe w przestrzeni prywatnej i publicznej.

${ }^{13}$ W tym kontekście należy mieć na uwadze dynamiczny rozwój osobowości ucznia szkoły muzycznej, jego sposób myślenia oraz szeroko rozumianą wrażliwość, która w procesie edukacji ulega daleko idącym przeobrażeniom. Zjawisko to - szczególnie wyraźnie zarysowujące się w obrębie zachowań typowych dla wieku dorastania (13.-19. rok życia) - opisuje Beata Bonna. Zwraca ona uwagę na prawidłowość, iż w tym właśnie przedziale wiekowym pojawia się „większe zrozumienie i zainteresowanie formą utworu, zaczynają się kształtować początki obiektywno-estetycznej postawy wobec słuchanych utworów muzycznych. Młodzież poszukuje w muzyce możliwości prze- 
Nie pozostaje to bez wpływu na powstawanie specyficznych, nielinearnych, na swój sposób horyzontalnych relacji ucznia z nauczycielem. Ten pierwszy, jeżeli tylko pozwoli mu na to odpowiednio elastyczna organizacja i sposób prowadzenia zajęć, poszukiwał będzie niejednokrotnie możliwości rozwoju swoich zdolności artystycznych „w sytuacji wolności, której brak w strukturze hierarchicznej, ta bowiem reguluje wszelkie obszary niepewności, przekształcając je w niezachwianą pewność” ${ }^{14}$. „Sieciowe" kształtowanie się relacji na linii uczeń-nauczyciel, zastępujące sztywny model autorytarny, może przyczynić się do częściowego przesunięcia symetrycznych ram organizacyjnych zajęć. Mimo to wnosi ze sobą niejednokrotnie znaczące korzyści, wynikające ze stworzenia zmodyfikowanego środowiska lekcyjnego, przenoszącego uczestników zajęć do obszaru w dużej mierze wyzwolonego spod zgubnego działania dydaktycznej rutyny, czy metodycznej jednorodności ${ }^{15}$.

Rozważając kwestię sposobu organizacji zajęć języka obcego w szkole muzycznej, nietrudno dojść do przekonania, że uczniowie aktywizują się w sposób szczególny pod wpływem impulsów, w których działania dydaktyczne bazujące na użyciu podręcznika uzupełnione zostają przez przygotowane osobno treści muzyczne. Niezwykle istotne jest przy tym zachowanie odpowiednich proporcji. Jednakże nawet przy niewielkim wprowadzeniu treści muzycznych nauka języka obcego zyskuje na atrakcyjności, opiera się bowiem na preferowanej w środowisku artystycznym wielokanałowości przekazu. Trudne do przecenienia jest ponadto zastosowanie inspirującego oddziaływania utworów muzycznych, nie tylko poddawanych biernej recepcji, lecz także twórczo przetwarzanych. W tym kontekście należy zwrócić uwagę na fakt, że śpiew, czy w ogólnym ujęciu operowanie dźwiękami - inaczej niż ma to miejsce w szkołach „niemuzycznych” - jest w warunkach nauki w szkole opisywanej w niniejszym artykule częścią codziennej praktyki, realizowanej m.in. w ramach takich zajęć

żyć, wzruszeń oraz odreagowania narastających stresów emocjonalnych charakterystycznych dla tego okresu życia”. B. Bonna, Zdolności muzyczne - ich rozwój i uwarunkowania. Wybrane koncepcje uzdolnienia muzycznego, [w:] W. Limont, J. Cieślikowska (red.), Wybrane zagadnienia edukacji uczniów zdolnych, t. 3, Zdolności i stymulowanie ich rozwoju, Oficyna Wydawnicza „Impuls”, Kraków 2005, s. 263. Z drugiej strony nie wolno zapomnieć o dynamicznie kształtującej się w wieku dojrzewania podmiotowości uczniów, u których wzrasta poczucie własnej tożsamości, połączone $\mathrm{z}$ uporczywym dążeniem do autonomii w podejmowanych przedsięwzięciach. Zob. M. Kwaśniewska, Indywidualizacja pracy $z$ dzieckiem w edukacji przedszkolnej, [w:] J. Skibska, E. Kochanowska (red.), Uczeń w teorii i praktyce pedagogicznej. Dylematy współczesnej edukacji, Wydawnictwo Naukowe Akademii Techniczno-Humanistycznej w Bielsku Białej, Bielsko-Biała 2013, s. 39.

${ }^{14}$ M. Jaworski, Edukacja artystyczna, uczeń zdolny i przemiany kultury wspótczesnej, [w:] W. Limont, J. Cieślikowska, J. Dreszer (red.), Osobowościowe i środowiskowe uwarunkowania rozwoju ucznia zdolnego, Wydawnictwo Naukowe Uniwersytetu Mikołaja Kopernika, Toruń 2010, s. 79.

${ }^{15}$ Nadmierny „strukturalizm dydaktyczny”, objawiający się m.in. sztywnymi ramami czasowymi regulującymi sposób rozwijania poszczególnych sprawności, czy radykalnym rozdzielaniem kształcenia w zakresie teorii od działania mającego charakter praktyczny - na co zwracał uwage już przed ponad trzydziestu laty Konstanty Lech - uznać należy z dzisiejszej perspektywy za model dalece anachroniczny. Zob. K. Lech, Łączenie teorii z praktyką w nauczaniu, Wydawnictwa Szkolne i Pedagogiczne, Warszawa 1987, s. 13. 
lekcyjnych jak harmonia czy kształcenie słuchu. Stąd też zastosowanie aktywnego muzykowania na zajęciach języka obcego nie pociąga za sobą onieśmielenia, skrępowania czy poczucia niezwykłości sytuacji - wręcz przeciwnie - wnosi ze sobą pozytywny ładunek afektywny. Wobec powyższego uprawnione wydaje się twierdzenie, że nic tak skutecznie nie uzupełnia pracy z podręcznikiem do nauki języka obcego, jak wspólne aranżowanie i wykonywanie podczas zajęć lekcyjnych utworów muzycznych, względnie wplatanie w przebieg lekcji szeroko rozumianego kanonu muzyki artystycznej i popularnej.

Wykoncypowane w oparciu o opisane powyżej zasady lekcje języka obcego, odchodzące w swoim przebiegu od schematycznego kształcenia podstawowych sprawności, tworzą aurę pewnej wielowarstwowości i „polifoniczności”. Obok ćwiczeń gramatyczno-leksykalnych, pracy z tekstem, popularnych „słuchanek” czy kształcenia zdolności mówienia i pisania ${ }^{16}$, pojawia się bowiem zindywidualizowany przekaz treści językowych, oparty na nośności ekspresyjnej muzyki wokalnej i wokalno-instrumentalnej. Przekaz ten zostaje przeważnie rozkodowany przez uczestników zajęć w kategoriach treści wpisujących się w ich oczekiwania i zainteresowania. Mając na uwadze to, iż prezentacja materiałów dźwiękowych odbywa się często przy jednoczesnym zastosowaniu szeroko rozumianych multimediów, całość przebiega na płaszczyźnie stymulacji opartej na rozszerzonym zasobie środków ${ }^{17}$. Pociąga to za sobą znaczące zmodyfikowanie całego środowiska lekcyjnego, a zmiana ta jest o tyle istotna, iż pozwala osiągnąć dodatkowe cele dydaktyczne, gdyż nauczyciel, dążąc do wyeliminowania rutynowych, często niepożądanych zachowań uczestników zajęć, korzysta jednocześnie z uprzywilejowanej pozycji, wynikającej z wprowadzonych uprzednio modyfikacji ${ }^{18}$.

\section{Nowoczesna dydaktyka w szkole muzycznej a rola metod tradycyjnych}

Rozważając szerszy kontekst metodyczny organizacji zajęć w szkole muzycznej, należy mieć na uwadze fakt, że komplementarnym trzonem kształcenia w placówce tego typu, stojącym niejako w opozycji do wspomnianej sfery rozwijania wielopłaszczyznowej kreatywności, spontaniczności i improwizacji, jest systematyczne szkolenie tzw. warsztatu. Działanie to oparte jest na wymagającym, rozciągniętym w czasie,

${ }^{16}$ Szeroki wachlarz różnorakich możliwości metodycznych w odniesieniu do wspomnianych powyżej sprawności znaleźć można w ćwiczeniach komunikacyjnych Hanny Komorowskiej. Zob. H. Komorowska (red.), Ćwiczenia komunikacyjne w nauce języka obcego, Wydawnictwa Szkolne i Pedagogiczne, Warszawa 1988.

${ }_{17}$ Por. J. Bednarek, Multimedia w ksztatceniu, Wydawnictwo Naukowe PWN, Warszawa 2006, s. 8.

${ }_{18}$ Zob. C.H. Edwards, Dyscyplina i kierowanie klasa, przeł. M. Bogdanowicz, Wydawnictwo Naukowe PWN, Warszawa 2006, s. 199. 
na swój sposób strukturalnym procesie ćwiczeniowym. W warstwie szczegółowej w odniesieniu do przedmiotów „kierunkowych” - chodzi o doskonalenie zdolności manualnych, względnie głosowych, i ich odpowiedniego synchronizowania $\mathrm{z}$ wyobraźnią i wrażliwością muzyczną. Dlatego też na lekcjach języka obcego, realizowanych w szkołach muzycznych, nie powinno zabraknąć konsekwentnie implementowanej strategii opartej na schemacie ćwiczeniowym i metodach tradycyjnych, z jednej strony bazujących na swoistej indywidualizacji ${ }^{19}$, $\mathrm{z}$ drugiej zaś kładących nacisk na kształtowanie kompetencji językowych w warunkach systemowego, strukturalnego sposobu działania ${ }^{20}$.

Z praktyki nauczyciela języka niemieckiego, którą zdobywałem w Państwowej Ogólnokształcącej Szkole Muzycznej II stopnia im. K. Szymanowskiego w Katowicach - szkole silnie kształtującej potencjał imaginacyjny uczniów z uwagi na oddziaływanie legendy wybitnych absolwentów, do których zaliczyć należy przede wszystkim Krystiana Zimermana i Wojciecha Kilara - wynika jednoznacznie, że satysfakcjonujące rezultaty dydaktyczne przynosi rozciągnięte w czasie konsekwentne ćwiczenie sprawności językowych, oparte na połączeniu zindywidualizowanych metod komunikacyjnych z tzw. tradycyjnymi, „strukturalnymi” założeniami metodycznymi.

Dużą rolę przypisać należy przy tym metodzie bezpośredniej, znajdującej swoje zastosowanie w szczególności w pierwszej fazie lekcji, najczęściej w czasie rozgrzewki przygotowującej do kolejnych etapów realizacji zajęć, podczas której (przy uwzględnieniu stosunkowo niewielkiej wariantywności) postawione zostają pytania dotyczące spraw codziennych: samopoczucia, zainteresowań, preferencji kulinarnych czy sposobu spędzania czasu wolnego. Uporczywe powtarzanie tych samych formuł zdaniowych oraz uzyskiwanie podobnych do siebie schematycznych, nierzadko lakonicznych czy wręcz groteskowych odpowiedzi (na przykład: [pytanie:] „Was isst Du gern?”, [odpowiedź:] „Wurst”) mogłoby wydawać się postronnemu obserwatorowi dziwaczne i mało przekonujące. Taki układ wprowadzenia zajęć i wstępnej aktywiza-

${ }^{19} \mathrm{~W}$ ramach uzupełnienia strategii dydaktycznych trudno przecenić założenia koncepcyjne tutoringu, a zatem metody reprezentującej ważny nurt edukacji, którą można określić mianem edukacji spersonalizowanej. W modelu tym prowadzący zajęcia opiera się przede wszystkim na pracy z mocnymi stronami podopiecznego. Tutorzy - powołując się na opinię Ewy Musiał - choć często nie jest to proste, mają za zadanie znaleźć w każdym uczniu talent, obszar, który warto rozwijać, który w konsekwencji powinien stanowić podstawę pracy nauczyciela-tutora i inspirację do odpowiedniej implementacji przygotowanych zasobów metodycznych. Zob. E. Musiał, Tutoring w pracy nowoczesnego nauczyciela, [w:] J. Skibska, E. Kochanowska, Uczeń w teorii i praktyce pedagogicznej. Dylematy współczesnej edukacji, Wydawnictwo Naukowe Akademii Techniczno-Humanistycznej w Bielsku Białej, Bielsko-Biała 2013, s. 55-56.

${ }^{20}$ Nie musi to wcale pociągać za sobą znaczącego ograniczenia uczniowskiej autonomii; inicjowanie samodzielnego działania i dostarczanie okazji do zdobywania kompetencji przez częste ćwiczenie i powtarzanie schematycznych czynności może otworzyć drogę do ich twórczego przetwarzania. Por. A. Studenska, Rola nauczyciela w ksztattowaniu autonomii ucznia, [w:] D. Kocurek (red.), Rodzina i szkoła wobec realiów i wyzwań XXI wieku, Wydawnictwo „Scriptum”, CieszynKatowice-Kraków 2010, s. 140. 
cji ich uczestników przypomina jednak popularną na lekcjach gry na instrumencie (względnie na indywidualnych i grupowych zajęciach wokalnych) rozgrzewkę, niemającą przecież wygórowanych aspiracji artystycznych, a polegającą na powtarzaniu tych samych, dobrze znanych schematów. Działanie to jawi się jednak niewątpliwie pożyteczne w kontekście osiągania dalszych celów. Ubocznym „zyskiem” tej metody na zajęciach językowych jest kształtowanie zdolności rozumienia szeregu podstawowych pytań, a niewątpliwym atutem - wykształcenie automatyzmu w udzielaniu odpowiedzi, co niewątpliwe wpisuje się w główne założenia metody bezpośredniej.

\section{Systematyczne kształcenie sprawności językowych}

W przyjętej powyżej koncepcji kształcenia schematów obecne jest przede wszystkim typowe dla szkoły muzycznej doskonalenie tzw. warsztatu. Przechodząc do praktycznej egzemplifikacji w innym zakresie: dobre rezultaty przynosi również zastąpienie tradycyjnego wywołania do odpowiedzi działaniem dwuetapowym: w pierwszej kolejności kształcenie i ocenianie zdolności czytania (na podstawie losowo wybranej partii przerobionego tekstu), a dopiero w późniejszym okresie zdolności budowania kompleksowej wypowiedzi ustnej. Wykształcenie zdolności biegłego czytania otwiera niewątpliwie drogę i skutecznie przygotowuje do połączonej z nią kompetencji w obszarze samodzielnego tworzenia wypowiedzi. Ponieważ w dwusemestralnym cyklu kształcenia w zakresie poszczególnych sprawności językowych chodzi o sukcesywne i kompleksowe ćwiczenie oraz ocenianie wszystkich z nich, wymagająca indywidualizacji praca nad kompetencjami ustnymi rozszerzona zostaje następnie o wykonanie zadania polegającego na napisaniu krótkiego wypracowania na zadany temat ${ }^{21}$. Zwieńczeniem całości jest przeprowadzenie pod koniec roku szkolnego testu na rozumienie ze słuchu ${ }^{22}$. Co się tyczy sfery motywacyjnej, organizacyjnej i pragmatycznej przedstawionego powyżej modelu dydaktycznego: systematyczne i obligatoryjne wystawianie ocen z wszystkich czterech sprawności językowych na przestrzeni dwóch semestrów tworzy w oczach uczestników zajęć wrażenie pewnej zamkniętej całości mówiąc językiem szkoły muzycznej: homofonicznej harmonii - dając uczestnikom zajęć poczucie osiągnięcia postępów w całościowo rozumianym obszarze kompeten-

21 Najczęściej ma to miejsce w połowie drugiego semestru roku szkolnego.

22 Ważnym założeniem przy całościowym ocenianiu wspomnianych sprawności jest konsekwentne dążenie do możliwie daleko idącej obiektywizacji. Choć wydawać się to może oczywistością, nic tak nie zniechęca uczniów do indywidualnej pracy i aktywności na zajęciach jak wrażenie, że nauczyciel faworyzuje pewną część grupy, pozostając obojętnym w stosunku do innych. Zob. A. Kargulowa, Dlaczego dzieci nie lubia szkoły?, Wydawnictwa Szkolne i Pedagogiczne, Warszawa 1991, s. 87. 
cyjnym. Cechą charakterystyczną takiego sposobu postępowania i oceniania jest ponadto intensyfikacja działań „aktywnych” $i$ „podmiotowych”23.

\section{Kontekst kulturowy, podsumowanie}

Zindywidualizowany model nauczania aktywnego, czy inaczej mówiąc, podmiotowego, to - jak słusznie zauważa Beata Oelszlaeger-Kosturek - „potrzeba czasów zdominowanych przez zjawisko globalizacji”24. Zdobyte tym sposobem umiejętności kontrolne i oceniające otwierają drogę do kształcenia wielopłaszczyznowych kompetencji w zakresie podejmowania decyzji oraz przyjmowania odpowiedzialności za dokonane wybory. Ponieważ dzisiejsza kultura masowa jest silnie związana z konsumpcją i od konsumpcji w dużym stopniu zależy, dominują w niej - na co zwraca uwagę Małgorzata Bogunia-Borowska - takie pojęcia i „wartości”, jak: sukces (finansowy, zawodowy i osobisty), kreatywność, konkurencyjność, wszelkiego rodzaju przyjemności, zabawa, młodość (kult ciała) oraz wiedza (zarówno ta technologiczna, jak i ogólnospołeczna związana z komercją i reklamą ${ }^{25}$. Ważną cechą dystynktywną dzisiejszej kultury masowej jest również, jeżeli nie przede wszystkim, prymat indywidualności, coraz częściej manifestujący się i eskalujący - jak to ma miejsce w mediach społecznościowych - w zachowaniach egoistycznych i narcystycznych.

Wobec powyższych procesów zmianie ulega siłą rzeczy relacja ucznia z nauczycielem. Sztywny gorset autorytarny zastąpiony zostaje powszechnie przez moduł regulacji sieciowych, co niewątpliwie staje się wyzwaniem dla edukacji artystycznej i refleksji nad uczniem zdolnym. W obrębie oddziaływania procesów dydaktycznych pojawia się ponadto kwestia niespotykanych wcześniej zjawisk, takich jak nieciągłość form, dyskursów i idei ${ }^{26}$. Zmiana w postrzeganiu procesów dydaktycznych, będąca wypadkową zmian zachodzących w wyniku przemian paradygmatycznych i postępujących procesów globalizacji, komercjalizacji i demokratyzacji edukacji - jak zauważa Małgorzata Kwaśniewska - daje podstawy do twierdzenia, iż „można dziś mówić o nadrzędności indywidualizacji względem innych zasad”27.

Podjęcie wielu działań dydaktycznych nacechowanych indywidualizacją daje niewątpliwie różnorakie możliwości i szanse. W odniesieniu do uczniów szkół mu-

${ }^{23}$ Por. B. Oelszlaeger-Kosturek, Realizacja idei uczenia się aktywnego dzieci w teorii i praktycewybrane problemy, [w:] J. Skibska, E. Kochanowska (red.), Uczeń w teorii i praktyce pedagogicznej. Dylematy współczesnej edukacji, Wydawnictwo Naukowe Akademii Techniczno-Humanistycznej w Bielsku Białej, Bielsko-Biała 2013, s. 25.

${ }^{24}$ Tamże, s. 35.

${ }_{25}$ Zob. M. Bogunia-Borowska, Infantylizacja kulturowa. Adolescencja dzieci oraz infantylizacja dorostych, [w:] M. Bogunia-Borowska (red.), Dziecko w świecie mediów i konsumpcji, Wydawnictwo Uniwersytetu Jagiellońskiego, Kraków 2006, s. 13-14.

${ }^{26}$ Por. M. Jaworski, dz. cyt., s. 84.

${ }^{27}$ M. Kwaśniewska, dz. cyt., s. 42. 
zycznych, oprócz aspektów opisanych powyżej, pozwala ono pozytywnie wpłynąć na procesy decyzyjne. Dotyczą one bezpośrednio uczestników zajęć, którzy obciążeni wielością obowiązków, podają niejednokrotnie w wątpliwość posiadanie wystarczającego potencjału i zdolności ${ }^{28}$, koniecznych do sprostania niełatwemu zadaniu, jakim jest nauka w szkole artystycznej. Zastosowanie rozszerzonego, zindywidualizowanego instrumentarium metodycznego, dowartościowującego odbiorców zajęć dydaktycznych, może niewątpliwie przyczynić się do znaczącej redukcji pojawiających się uporczywie wątpliwości i dylematów.

\section{Bibliografia}

Bednarek J., Multimedia w kształceniu, Wydawnictwo Naukowe PWN, Warszawa 2006.

Bogunia-Borowska M., Infantylizacja kulturowa. Adolescencja dzieci oraz infantylizacja dorosłych, [w:] M. Bogunia-Borowska (red.), Dziecko w świecie mediów i konsumpcji, Wydawnictwo Uniwersytetu Jagiellońskiego, Kraków 2006.

Bonna B., Zdolności muzyczne - ich rozwój i uwarunkowania. Wybrane koncepcje uzdolnienia muzycznego, [w:] W. Limont, J. Cieślikowska (red.), Wybrane zagadnienia edukacji uczniów zdolnych, t. 3, Zdolności i stymulowanie ich rozwoju, Oficyna Wydawnicza „Impuls”, Kraków 2005.

Cieślikowska J., Limont W., Obraz ucznia zdolnego w potocznych koncepcjach nauczycieli, [w:] W. Limont, J. Cieślikowska, J. Dreszer (red.), Osobowościowe i środowiskowe uwarunkowania rozwoju ucznia zdolnego, Wydawnictwo Naukowe Uniwersytetu Mikołaja Kopernika, Toruń 2010.

Edwards C.H., Dyscyplina i kierowanie klasą, przeł. M. Bogdanowicz, Wydawnictwo Naukowe PWN, Warszawa 2006.

Foryś M., Diagnoza nauczycielska zdolności, [w:] M. Czarnocka, M. Foryś, K. Truś (red.), Rozpoznać, wspierać, rozwijać. Poradnia psychologiczno-pedagogiczna i szkoła a uczeń zdolny, Ośrodek Rozwoju Edukacji, Warszawa 2014.

Jaworski M., Edukacja artystyczna, uczeń zdolny i przemiany kultury współczesnej, [w:] W. Limont, J. Cieślikowska, J. Dreszer (red.), Osobowościowe i środowiskowe uwarunkowania rozwoju ucznia zdolnego, Wydawnictwo Naukowe Uniwersytetu Mikołaja Kopernika, Toruń 2010.

Jurewicz M., Instytucjonalne wspieranie rozwoju uczniów zdolnych muzycznie, [w:] W. Limont, J. Cieślikowska, J. Dreszer (red.), Osobowościowe i środowiskowe uwarunkowania rozwoju ucznia zdolnego, Wydawnictwo Naukowe Uniwersytetu Mikołaja Kopernika, Toruń 2010.

\footnotetext{
${ }^{28}$ Por. E. Szatan, dz. cyt., s. 308.
} 
Kargulowa A., Dlaczego dzieci nie lubia szkoły?, Wydawnictwa Szkolne i Pedagogiczne, Warszawa 1991.

Komorowska H. (red.), Ćwiczenia komunikacyjne w nauce języka obcego, Wydawnictwa Szkolne i Pedagogiczne, Warszawa 1988.

Kwaśniewska M., Indywidualizacja pracy z dzieckiem w edukacji przedszkolnej, [w:] J. Skibska, E. Kochanowska (red.), Uczeń w teorii i praktyce pedagogicznej. Dylematy współczesnej edukacji, Wydawnictwo Naukowe Akademii Techniczno-Humanistycznej w Bielsku Białej, Bielsko-Biała 2013.

Lech K., Łączenie teorii z praktyka w nauczaniu, Wydawnictwa Szkolne i Pedagogiczne, Warszawa 1987.

Musiał E., Tutoring w pracy nowoczesnego nauczyciela, [w:] J. Skibska, E. Kochanowska, Uczeń w teorii i praktyce pedagogicznej. Dylematy wspótczesnej edukacji, Wydawnictwo Naukowe Akademii Techniczno-Humanistycznej w Bielsku Białej, Bielsko-Biała 2013.

Oelszlaeger-Kosturek B., Realizacja idei uczenia się aktywnego dzieci w teorii i praktyce - wybrane problemy, [w:] J. Skibska, E. Kochanowska (red.), Uczeń w teorii i praktyce pedagogicznej. Dylematy współczesnej edukacji, Wydawnictwo Naukowe Akademii Techniczno-Humanistycznej w Bielsku Białej, Bielsko-Biała 2013.

Sasin M., Kanon wykonawczy muzyki poważnej jako przestrzeń spotkania Innego, „Kultura i Wychowanie” 2018, nr 2.

Studenska A., Rola nauczyciela w kształtowaniu autonomii ucznia, [w:] D. Kocurek (red.), Rodzina i szkoła wobec realiów i wyzwań XXI wieku, Wydawnictwo „Scriptum”, Cieszyn-Katowice-Kraków 2010.

Szatan E., Kształcenie ucznia zdolnego na przykładzie Ogólnokształcacej Szkoły Muzycznej I i II stopnia w Gdańsku, [w:] W. Limont, J. Cieślikowska (red.), Wybrane zagadnienia edukacji uczniów zdolnych, t. 1, Zdolności i stymulowanie ich rozwoju, Oficyna Wydawnicza „Impuls”, Kraków 2005.

\section{Individualisation and "polyphonization" of foreign language teaching in music schools}

Abstract: The musical environment requires a foreign language teacher to take a number of actions that go beyond standard methodological assumptions. The unconventional way of shaping the didactic process at arts schools is primarily due to the increased level of sensitivity of class participants and non-standard expectations of teachers. Students who prefer an individual way of learning show significant interest in the direct method, setting themselves - following the example of music classes - to practice handy and useful patterns.

Keywords: foreign languages, teaching methodology, arts schools, multi-channel teaching processes, individualization 
About the author: Tobiasz Janikowski - Ph.D., researcher and lecturer in the Department of History and Culture of the Countries of the German Language Area of the Pedagogical University in Krakow. From 2010-2017 he was a German language teacher at the State Secondary K. Szymanowski Music School in Katowice. His research interests include: the cultural phenomenon of the Polish-German borderland, the problem of identity and collective identification of residents of multi-ethnic areas, the impact of digital media on teaching processes, and social and cultural changes. 
Anna Mikler-Chwastek* (iD) https://orcid.org/0000-0003-2026-6749

Akademia Pedagogiki Specjalnej im. Marii Grzegorzewskiej w Warszawie

https://doi.org/10.25312/2083-2923.17/2020_08amc

\title{
Trudności w organizacji współpracy między nauczycielami a rodzicami uczniów - sprawozdanie $\mathbf{z}$ badań
}

\begin{abstract}
Streszczenie: Organizacja dobrej współpracy nauczyciela z rodzicami jest jednym z najistotniejszych warunków sprawowania opieki nad uczniem. Przyjmując dziecko do szkoły, mamy przecież do czynienia nie tylko z pojedynczą osobą, ale także jego otoczeniem rodzinnym. To właśnie najbliżsi stanowią jego środowisko wychowawcze, wpływają na proces rozwoju i wychowania, wyznaczają cele, oczekują pewnych efektów. Zatem to właśnie rodzic staje się dla nauczyciela partnerem do współpracy i współdziałania na rzecz dziecka. Obie strony będą starały się tak organizować swoje działania, by pomóc dziecku osiągnąć jak najwięcej. Jednak by tak się stało, muszą się poznać, obdarzyć zaufaniem, wypowiedzieć i zrozumieć wzajemne oczekiwania. To proces długotrwały, nieraz trudny, wymagający zaangażowania i chęci osiągnięcia porozumienia.
\end{abstract}

Słowa kluczowe: rodzic, nauczyciel, organizacja współpracy, szkoła

* Anna Mikler-Chwastek - doktor nauk humanistycznych, pracuje w Katedrze Pedagogiki Małego Dziecka w Akademii Pedagogiki Specjalnej w Warszawie. Zajmuje się problematyką związaną z dotykowym poznawaniem siebie i otoczenia przez niemowlęta i małe dzieci, nabywaniem kompetencji w zakresie samodzielności elementarnej w przypadku dzieci w wieku poniemowlęcym i przedszkolnym oraz problematyką związaną z rozwojem prawidłowym i zaburzonym małych dzieci. 
Efekt współdziałania grupy ludzi zorganizowanej w zespół jest większy niż suma efektów działań pojedynczych.

Tadeusz Kotarbiński

\section{Rodzina i szkoła jako środowiska współpracujące}

Rodzina stanowi pierwsze i najważniejsze środowisko wychowawcze człowieka. To $\mathrm{w}$ niej rozpoczyna się proces wychowania i socjalizacji, wprowadzania w świat wiedzy, umiejętności i kompetencji społecznych. Zatem oddziaływanie rodziny na młodego człowieka jest niezwykle silne, można stwierdzić, że wręcz dominujące. Od postaw rodzicielskich ${ }^{1}$, stylów wychowania preferowanych przez rodziców ${ }^{2}$ będzie w dużej mierze zależało zachowanie dziecka i to, jak poradzi sobie $\mathrm{z}$ trudnościami, a także w jaki sposób będzie budowało relacje społeczne. Zadaniem rodziców jest także zabezpieczanie dziecięcych potrzeb. Wiele zatem zależy od tego, z jakimi warunkami się ono spotka, jak będzie wyglądała organizacja jego życia, w jaki sposób będzie ono funkcjonowało, a także czy będą zaspokojone jego potrzeby emocjonalne (akceptacji, miłości, życzliwości, ciepła)³. To także rodzic jest odpowiedzialny za wprowadzenie dziecka w nowy obszar, jakim jest szkoła.

Drugim ważnym środowiskiem wychowawczym jest szkoła. Co prawda, jej zadania polegają w dużej mierze na organizacji procesu edukacyjnego, ale nie może on przecież zaistnieć bez oddziaływań wychowawczych. Skoro nauczyciel regularnie przez kilka godzin dziennie, często przez wiele lat pracuje z uczniem, opiekuje się nim, uczy, wychowuje, ma na niego wpływ, to znaczy, że również powinien mieć na uwadze budowanie kontaktów z jego rodzicami. To dzięki współpracy obu środowisk wychowawczych możliwe jest pokonywanie ewentualnych trudności oraz rzetelna i systematyczna praca wychowawcza i edukacyjna.

Zarówno rodzice, jaki i nauczyciele dokładają starań, by wdrożyć dziecko do pełnej samodzielności życiowej. Chcą, by przyswoiło wiedzę, zdobyło odpowiednie umiejętności, radziło sobie w budowaniu relacji międzyludzkich, rozwijało się na

${ }^{1}$ Postawy prawidłowe charakteryzują się: akceptacją, bezpieczeństwem, partnerstwem, zrozumieniem, konsekwencją, miłością, uznawaniem praw dziecka. Postawy nieprawidłowe charakteryzują się: nadmiernym wymaganiem, odtrącaniem, unikaniem, nadmiernym chronieniem. D.M. Boruc, Wspótpraca rodzic - szkoła w edukacji dziecka. Po co i dlaczego?, [w:] E. Kopeć (red.), W trosce o edukacje dziecka, Wydawnictwo B\&G, Warszawa 2015, s. 64.

${ }^{2}$ Styl demokratyczny - dziecko jest traktowane podmiotowo, jest pełnoprawnym członkiem rodziny, ma prawa i obowiązki. Styl liberalny - brak reguł postępowania dla dziecka, nadmierna swoboda, pobłażliwość i uległość. Styl autokratyczny - duży dystans w relacjach z dzieckiem, formalne kontakty, brak czułości, brak akceptacji dla błędów.

${ }^{3}$ L. Pawelec, Dziecko i jego środowisko rodzinne, [w:] E. Smak (red.), Nauczyciel w edukacji przedszkolnej, Wydawnictwo Uniwersytetu Opolskiego, Opole 2006, s. 185. 
miarę swoich możliwości. Można zatem powiedzieć, że ich wspólnym celem jest dbanie o prawidłowy rozwój dziecka .

Z jednej strony, podjęcie współpracy z nauczycielem jest możliwością, przywilejem, jaki otrzymuje rodzic ucznia, a z drugiej strony, staje się to jego obowiązkiem wynikającym z postanowień i uregulowań prawnych. Współpracę rodziców ze szkołą warunkują następujące przepisy:

- Ustawa z dnia 7 września 1991 r. o systemie oświaty:

- art. 1 pkt 1: szkoła wspomaga wychowawczą rolę rodziny;

- art. 18: czynności rodziców związane z realizacją obowiązku szkolnego;

- art. 15 ust. 2: rodzice są odpowiedzialni za realizację obowiązku szkolnego dziecka, który rozpoczyna się z początkiem roku szkolnego w roku kalendarzowym, w którym dziecko kończy 6 lat, oraz trwa do ukończenia gimnazjum, nie dłużej jednak niż do ukończenia 18. roku życia;

- Kodeks rodzinny i opiekuńczy:

- art. $96 \$ 1$ ustawa z dnia 25 lutego 1964 r.: rodzice wychowują dziecko pozostające pod ich władzą rodzicielską i nim kierują;

- Europejska karta praw i obowiązków rodziców:

- pkt 4: rodzice mają obowiązek przekazywania wszelkich informacji szkołom, do których uczęszczają ich dzieci, informacji dotyczących możliwości osiągnięcia wspólnych (tj. domu i szkoły) celów edukacyjnych;

- pkt 7: rodzice mają obowiązek osobiście włączać się w życie szkół ich dzieci i stanowić istotną część społeczności lokalnej;

- pkt 9: rodzice mają obowiązek poświęcać swój czas i uwagę swoim dzieciom i ich szkołom, tak aby wzmocnić ich wysiłki skierowane na osiągnięcie określonych celów nauczania.

Współpraca placówki edukacyjnej z rodzicami wynika także z uregulowań prawnych oraz postanowień przyjętych w regulaminach wewnątrzszkolnych, takich jak:

- statut szkoły (Rozporządzenie Ministra Edukacji Narodowej z dnia 21 maja 2001 r. w sprawie ramowych statutów publicznego przedszkola oraz publicznych szkół),

- regulamin rady rodziców (Prawo oświatowe, art. 83 i art. 84 ustawy z 14 grudnia 2016 r.),

- program wychowawczy,

- wewnątrzszkolny system oceniania ${ }^{5}$ (Rozporządzenie Ministra Edukacji Narodowej z dnia 30 kwietnia 2007 r. ze zmianami z dnia 30 kwietnia 2013 roku w sprawie warunków i sposobu oceniania, klasyfikowania i promowania

${ }^{4}$ D.M. Boruc, dz. cyt., s. 62.

${ }_{5}$ T. Sokołowska-Dzioba, Formy współpracy nauczycieli z rodzicami wedukacji szkolnej, [w:] D. Pankowska, T. Sokołowska-Dzioba (red.), Skuteczna edukacja szkolna w kontekście zadań nauczyciela wychowawcy, Wydawnictwo UMCS, Lublin 2015, s. 271-272. 
uczniów i słuchaczy oraz przeprowadzania sprawdzianów i egzaminów w szkołach publicznych).

Głównymi celami organizacji współpracy rodziców i nauczycieli są:

- niesienie pomocy w rozpoznawaniu możliwości rozwojowych dzieci - nauczyciel, jako specjalista mający wiedzę i kompetencje gromadzone w procesie własnej edukacji, przygotowania do zawodu, a także doświadczeń, potrafi rozpoznać potrzeby, zadatki uzdolnień, trudności rozwojowe, wychowawcze i edukacyjne swoich podopiecznych. Bywa często pierwszą osobą, która potrafi się w nich rozeznać. Dzięki pełnionej funkcji ma wpływ na kształtowanie się losów dziecka i dopasowywanie procesu uczenia do możliwości ucznia. We współpracy z jego rodziną jest to łatwiejsze, chodzi bowiem o wypracowanie wspólnej ścieżki postępowania dydaktyczno-wychowawczego;

- podejmowanie skutecznych działań wychowawczych - nauczyciel pełni funkcję opiekuna i wychowawcy. Spotyka się nie tylko z trudnościami w nauce swoich podopiecznych, ale także z całą gamą problemów wychowawczych związanych często z życiem rodzinnym uczniów;

- przekazywanie sobie nawzajem informacji na temat aktualnego stanu rozwoju dziecka - zarówno rodzic, jak i nauczyciel, pracując z dzieckiem (spędzając z nim czas), obserwują zmiany występujące w jego zachowaniu, postępy i deficyty rozwojowe. Organizacja dobrej współpracy pozwala na szybie reagowanie zwłaszcza w sytuacjach kryzysowych;

- organizacja bieżącej pracy klasy - wyjścia, wycieczki, zielona szkoła, uroczystości klasowe itp.

Zarówno rodzice, jak i nauczyciele są świadomi ciążącego na nich obowiązku budowania współpracy, jednak tworzenie i utrzymywanie dobrych relacji bywa obarczone trudnościami. W dalszej części tekstu postaram się je opisać, posiłkując się wynikami badań prowadzonych przeze mnie w tym zakresie.

\section{Metodologia badań}

Prowadząc badania nad współpracą między rodzicami a nauczycielami, posłużyłam się metodą teorii ugruntowanej ${ }^{6}$. Początkowo interesowały mnie tylko opinie nauczycieli na temat organizacji współpracy z rodzicami uczniów, a także to, jakie są, odnośnie do niej, ich oczekiwania. Jednak analizując wyniki (pozyskane dzięki badaniu ankietowemu), uznałam, że warto przyjrzeć się temu problemowi także z punktu wi-

${ }^{6}$ Metoda teorii ugruntowanej polega na budowaniu teorii dzięki zebranym danym empirycznym. Jest generowana w trakcie często długotrwałych badań, a nie na ich początku, dlatego tak ważne staje się gromadzenie danych przy pomocy obserwacji, wywiadów, raportów itp. Szczegółowy opis metody teorii ugruntowanej znajduje się w publikacji: K. Konecki, Studia z metodologii badań jakościowych. Teoria ugruntowana, PWN, Warszawa 2009, s. 26-28. 
dzenia rodziców. $Z$ tego powodu skonstruowałam ankietę pozwalającą zgromadzić dane dotyczące trudności we współpracy z nauczycielami, a także oczekiwań rodziców wobec tego, jak ona powinna ich zdaniem wyglądać.

Badania nad organizacją dobrej współpracy między rodzicami a nauczycielami prowadziłam w latach 2014-20157. Uczestniczyło w nich 60 nauczycieli klas I-III ze szkół publicznych i niepublicznych oraz klas zerowych, a także 60 rodziców uczniów uczęszczających do klas 0-III w szkołach publicznych i niepublicznych. Terenem badań było województwo mazowieckie. Prowadząc badania, posłużyłam się techniką ankiety zarówno dla rodziców, jak i nauczycieli.

\section{Trudności w organizacji wzajemnej współpracy między rodzicami a nauczycielami - wyniki badań}

Zacznę od prezentacji opinii nauczycieli na temat współpracy z rodzicami uczniów. Wszyscy uczestnicy badań stwierdzili, że zależy im na organizowaniu i podtrzymywaniu dobrej współpracy, jednak potrafili także wskazać to, co stanowi dla nich znaczący problem.

Badani nauczyciele wyróżnili trzy typy rodziców. Do pierwszego zaliczyli takich, z którymi współpraca układa się bardzo dobrze (60 nauczycieli wskazało takich rodziców). Można stwierdzić, że spełniają oni pewne oczekiwania wychowawcy8:

- szybko reagują na korespondencję mailową lub wiadomości zamieszczane w dzienniku elektronicznym (tego samego dnia albo następnego);

- odpowiadają na potrzeby (prośby) nauczyciela związane z pracą wychowawczą i organizacyjną (zgłaszają się do opieki nad dziećmi podczas wycieczek lub wyjść jednodniowych, przynoszą potrzebne materiały i pomoce, proponują współpracę podczas organizacji zielonej szkoły itp.);

- konstruktywnie podchodzą do trudności wychowawczych zdarzających się w klasie (nie oceniają nauczyciela, ale sytuację; starają się znaleźć rozwiązanie, szukają pomocy u specjalistów, np. proponują współpracę grupy z terapeutą lub psychologiem; zachęcają dyrekcję placówki do organizowania warsztatów dla rodziców i nauczycieli);

- w kulturalny sposób przekazują uwagi dotyczące pracy nauczyciela. Umawiają się na indywidualne spotkanie lub przekazują wiadomości drogą elektroniczną z zachowaniem zasad współżycia społecznego, nie są napastliwi ani agresywni,

${ }^{7}$ Pierwszą część wyników badań opisałam w publikacji A. Mikler-Chwastek, Dziecko, rodzic, nauczyciel. Zasady dobrej wspótpracy, [w:] K. Bocheńska-Włostowska, E. Kopeć (red.), W trosce o edukację dziecka, Wydawnictwo B\&G, Warszawa 2015, s. 185-201.

${ }^{8}$ Wymienione w punktach zachowania rodziców udało mi się podzielić na cztery kategorie: kontakt z nauczycielem, reakcje na prośby nauczyciela (zaangażowanie w pracę klasy), reakcja w sytuacjach trudnych, zgłaszanie uwag do pracy nauczyciela. 
nawet jeśli znaleźli się w sytuacji trudnej (np. ich dziecko zaangażowało się w bójkę, zniszczyło mienie szkolne).

Badani nauczyciele wskazali także inną grupę rodziców: nazwali ich obojętnymi, niereagującymi, nieobecnymi (60 nauczycieli spotkało się w pracy z takimi osobami). Co prawda, nie atakują oni nauczyciela, nie podważają jego kompetencji, nie tworzą grupy opozycyjnej. Jednak nie wykazują zainteresowania współpracą, trudno liczyć na ich pomoc, nie angażują się w działania na rzecz klasy. Co prawda, wypełniają swoje obowiązki (np. płacą za wycieczkę, uczeń ma potrzebne przybory i jest zadbany), jednak w relacjach z nauczycielem są nieobecni i nieaktywni. Do jakiegokolwiek zaangażowania zmusza ich tylko sytuacja trudna dotycząca ich dziecka (np. trudności w nauce, problem wychowawczy, kłopotliwe zdarzenie). W takim przypadku zgłaszają się do wychowawcy. Najczęściej próbują, na miarę swoich możliwości, rozwiązać problem, współpracując z wychowawcą. Jednak gdy sytuacja ulega poprawie, znowu wycofują się z zaangażowania. Badani nauczyciele zwracali uwagę, że ta grupa rodziców, co prawda nie przeszkadza im w pracy wychowawczej, ale też nie można na nich liczyć, gdy jest taka potrzeba. Ponad połowa badanych (45 osób) uznała, że takich rodziców w klasie jest większość.

Trzecią grupę rodziców nauczyciele ocenili jako najtrudniejszą we współpracy (aż 52 nauczycieli miało kontakt z takimi osobami), nazywali ich pieniaczami, opozycją, trudnymi rodzicami, rodzicami, z którymi nie da się współpracować. Zaznaczyli, że w grupie może być jedna lub kilka takich osób, jednak ich działania rzutują na organizację współpracy także z tymi, którzy do tej pory pozostawali bierni. Badani nauczyciele wskazali, że największym problemem dla nich w kontakcie $\mathrm{z}$ „trudnym” rodzicem jest: jego niechęć do wysłuchania opinii nauczyciela (43 osób), niedostatek kultury osobistej, w tym używanie wulgaryzmów (36 osób), brak właściwej (zdaniem nauczyciela) reakcji na potrzeby dziecka, np. lekceważenie zaleceń specjalistów (22 osoby), nagminne opuszczanie zajęć korekcyjnych, bagatelizowanie trudności zgłaszanych przez wychowawcę (22 osoby). Kilkunastu nauczycieli spotkało się z ośmieszaniem swojej osoby na forum klasy przez rodzica (12 osób), kilku było obrażanych w swojej społeczności poza pracą - byli to nauczyciele pracujący w małych miejscowościach, gdzie są dobrze rozpoznawani przez mieszkańców (3 osoby).

Badani nauczyciele najdotkliwiej odczuwają agresywne zachowania rodziców (40 badanych), brak zrozumienia ich pracy (40 badanych), a także zachowania seksistowskie - 35 badanych spotkało się choć raz z taką sytuacją (w badaniu brały udział tylko kobiety, gdyż w klasach 0 i I-III rzadko pracują mężczyźni).

Nauczyciele wskazali trzy grupy rodziców, z jakimi przychodzi im współpracować: angażujący się, bierni, agresywni. Kolejnym krokiem w badaniach była ocena współpracy z punktu widzenia rodzica. Interesowało mnie to, jak współpracę oceniają rodzice uczniów klas 0 i I-III, jakie dostrzegają trudności i problemy. Co ważne, wszyscy badani rodzice uważali, że współpraca z wychowawcą jest ważna dla dobrego funkcjonowania ich dziecka w szkole. 
Choć badani rodzice dostrzegają trudne sytuacje we współpracy z nauczycielem, to zdecydowana większość jest zadowolona z podejmowanych przez niego działań. Na pytanie: „Jak Pan/i ocenia współpracę z wychowawcą dziecka?” - 39 osób odpowiedziało, że bardzo dobrze lub dobrze, choć jednocześnie potrafili wskazać sytuacje, które im się nie podobają i wymagają korekty, by współpraca odbywała się na wysokim poziomie. Natomiast 12 rodziców oceniło współpracę z wychowawcą negatywnie. Oni także podali konkretne sytuacje, które miały wpływ na ich decyzję.

Badani rodzice wskazali kilka trudności, z jakimi spotykają się, współpracując z nauczycielami. Spora grupa (48 osób) zwróciła uwagę na to, że nauczyciele wymagają dużego zaangażowania $\mathrm{z}$ ich strony (przynoszenia różnego typu pomocy i materiałów, asystowania podczas wyjść i wycieczek). Woleliby, żeby ten obszar zabezpieczała szkoła. Część rodziców (28 osób) zwróciła uwagę, że wychowawcy nie liczą się z ich czasem, organizują spotkania w godzinach pracy rodzica, przedłużają zebrania (lub organizują je zbyt często), podczas zebrań przekazują nieistotne informacje, które można przesłać drogą mailową, zbyt mało czasu pozostaje na spotkania indywidualne.

Połowa rodziców (32 osoby) zwróciła uwagę na to, że dzieci są bezustannie oceniane i rozliczane ze swojej pracy, a ta zasada nie dotyczy nauczycieli (którzy, zdaniem rodziców, prawdopodobnie obawiają się oceny swojej pracy). Ten brak równowagi uznali za ważny w organizacji współpracy.

Część rodziców (23 osoby) zwróciła uwagę na sposób przekazywania informacji o dziecku w sytuacji, gdy wymagało ono dodatkowej pomocy (np. zajęć ze specjalistą) albo miało kłopoty z zachowaniem. Zaznaczyli w kwestionariuszu ankiety, że nauczyciel przekazał im tę informację w sposób nietaktowny, w obecności osób postronnych, na korytarzu podczas przerwy, w sposób zdawkowy. Chcieliby zostać potraktowani z szacunkiem i mieć czas na zadanie pytań.

W opinii części badanych (15 osób), nauczyciele nie zawsze jasno potrafią sformułować problemy dotyczące sytuacji w klasie, omawiają je na bardzo wysokim poziomie ogólności (np. „Klasa jest niegrzeczna, proszę porozmawiać z dziećmi”), rodzicom brakuje informacji, czego dotyczą problemy, czy trudność sprawia kilka osób, a może cała grupa, jakie są rzeczywiste zachowania dzieci, których nie akceptuje nauczyciel.

Pewna grupa badanych (12 osób) zarzuciła nauczycielowi to, że dokonał diagnozy dziecka, nie mając do tego uprawnień, czy nie znając sytuacji rodzinnej („Pani dziecko chyba ma autyzm, tak się dziwnie zachowuje”; „Słabo pisze - to pewnie dysleksja”).

\section{Wnioski z przeprowadzonych badań}

W badaniu wzięło udział w sumie 120 osób (po 60 z każdej grupy), wobec tego trudno jest dokonywać jakichkolwiek uogólnień, gdyż grupa badawcza nie była zbyt liczna, poza tym obejmowała osoby mieszkające na terenie tylko jednego województwa. Jednak wnioski, które nasuwają się po analizie wyników, mogą dać pewien ogląd sytu- 
acji związanej z nawiązywaniem współpracy między nauczycielami-wychowawcami a rodzicami uczniów z klas 0 oraz I-III.

Badani zdawali sobie sprawę z wagi wzajemnej współpracy. Uznali, że ma ona znaczenie dla procesu wychowawczego i edukacyjnego. Zarówno nauczyciele, jak i rodzice potrafili wskazać sytuacje trudne, które sprawiają, że owa współpraca nie zawsze układa się pomyślnie. Nauczyciele mieli zastrzeżenia przede wszystkim odnośnie do aktywnego angażowania się rodziców w pracę klasy. Część z nich czuła się niedoceniana lub wręcz ignorowana. Natomiast wielu rodziców czuło, że są nadmiernie angażowani w sprawy klasowe, choć ich zdaniem nie było takiej potrzeby. Wyraźnie zatem widać pewien konflikt: nauczyciel oczekuje intensywnej współpracy, ale rodzic (choć deklaruje, że jest na nią otwarty) często nie spełnia owych oczekiwań. Warto zadać pytanie - co można zrobić, by ów konflikt oczekiwań był mniej dotkliwy?

Zarówno rodzice, jak i nauczyciele wiedzą, że współpraca między nimi jest konieczna i nie negują tego faktu. Dysonans pojawia się na poziomie praktycznym, w bieżącej pracy: nauczyciel przekazuje informację o zdarzeniu/trudności i liczy na to, że rodzice zareagują szybko i konstruktywnie. Oni z kolei czują się przymuszeni do reakcji, nie zawsze też orientują się w tym, jak mogliby pomóc. Niebawem otrzymają informację: „Za mało się staracie, nie angażujecie się”. Jednak cała sytuacja rozgrywa się na poziomie oczekiwań: nauczyciel oczekuje, że rodzic zachowa się w określony sposób - a w tym czasie rodzic także ma jakieś oczekiwania wobec reakcji drugiej strony. Problem polega na niewerbalizowaniu owych oczekiwań i pozostawianiu dużej przestrzeni na domysły. Zatem jedną z istotnych kwestii w porozumieniu odgrywa proces przejrzystej i zrozumiałej komunikacji. Wyraźne określenie wzajemnych oczekiwań nie rozwiąże wszelkich problemów związanych z procesem współpracy, jednak pozwoli uniknąć wielu niepotrzebnych nieporozumień. Jednak trzeba pamiętać o tym, że jest to proces trudny, wymaga bowiem nie tylko sporej samoświadomości, ale też zrozumienia odczuć drugiej strony.

\section{Podsumowanie}

Podstawowym zadaniem szkoły jest wspieranie ucznia w nabywaniu wiedzy i umiejętności, a także kształtowanie jego postaw moralnych, budzenie odpowiedzialności, motywowanie do działania i podnoszenia swoich kompetencji. Jednak nawet najlepiej sformułowana i realizowana misja i wizja placówki nie wystarczą, by odnieść sukces.

Bezspornie konieczna jest odpowiednia organizacja współpracy między środowiskiem szkolnym a rodziną ucznia. Jednak proces ten napotyka wiele przeszkód, jak chociażby wzajemne niezrozumienie oczekiwań czy niedostateczne wczucie się w sytuację drugiej strony9.

${ }^{9}$ W. Żłobicki, Rodzice i nauczyciele w edukacji wczesnoszkolnej, Oficyna Wydawnicza Impuls, Kraków 2000, s. 79. 


\section{Bibliografia}

Boruc D.M., Współpraca rodzic - szkoła w edukacji dziecka. Po co i dlaczego?, [w:] E. Kopeć (red.), W trosce o edukację dziecka, Wydawnictwo B\&G, Warszawa 2015.

Konecki K., Studia z metodologii badań jakościowych. Teoria ugruntowana, PWN, Warszawa 2009.

Mikler-Chwastek A., Dziecko, rodzic, nauczyciel. Zasady dobrej współpracy, [w:] K. Bocheńska-Włostowska, E. Kopeć (red.), W trosce o edukację dziecka, Wydawnictwo B\&G, Warszawa 2015.

Pawelec L., Dziecko i jego środowisko rodzinne, [w:] E. Smak (red.), Nauczyciel w edukacji przedszkolnej, Wydawnictwo Uniwersytetu Opolskiego, Opole 2006.

Sokołowska-Dzioba T., Formy współpracy nauczycieli z rodzicami w edukacji szkolnej, [w:] D. Pankowska, T. Sokołowska-Dzioba (red.), Skuteczna edukacja szkolna w kontekście zadań nauczyciela wychowawcy, Wydawnictwo UMCS, Lublin 2015.

Żłobicki W., Rodzice i nauczyciele w edukacji wczesnoszkolnej, Oficyna Wydawnicza Impuls, Kraków 2000.

\section{Participation and cooperation of teachers with pupils' parents}

Abstract: The organization of good cooperation between teacher and parents is one of the most important conditions for taking care of a pupil. In admitting a child to school, we are dealing not only with an individual, but also with his/her family environment. A child's relatives constitute his/her educational environment, influence the development and upbringing process, set goals, expect certain effects. Therefore, it is the parent who becomes the teacher's cooperation and collaboration partner for the child. Both sides then try to organize their activities in such a way as to help the child achieve as much as possible. However, for this to happen, both sides must meet, trust each other, express and understand each other's expectations. It is a long-term process, sometimes difficult, requiring commitment and willingness to reach an agreement.

Keywords: parent, teacher, organization of cooperation, school

\footnotetext{
About the author: Ph.D., works in the Department of Small Child Pedagogy at the Maria Grzegorzewska University in Warsaw. She deals with issues related to the tactile learning of infants, the acquisition of competences in the field of elementary independence in the case of children of toddlers and preschoolers, as well as issues related to the development of normal and disturbed young children.
} 
Grażyna Cęcelek* iD https://orcid.org/0000-0002-2303-7442

Państwowa Uczelnia im. Stefana Batorego

https://doi.org/10.25312/2083-2923.17/2020_09gc

\title{
Specyfika przywództwa edukacyjnego w szkole oraz jej otoczeniu
}

\begin{abstract}
Streszczenie: Szkoła stanowi drugie po rodzinie ważne środowisko wychowawcze, będące nośnikiem nie tylko wiedzy, ale także norm, zasad oraz wartości społecznych. W stronę szkoły skierowane są nadzieje związane z kształtowaniem pożądanych kompetencji społecznych i zawodowych młodego pokolenia.

Instytucja szkoły nieustannie się zmienia i ewoluuje, dostosowując zasady i metody pracy do aktualnych potrzeb społeczeństwa. Priorytetem systemów edukacyjnych staje się antycypacja przyszłości oraz kształcenie do przeobrażeń zachodzących w każdej dziedzinie społecznego funkcjonowania.

Potrzeby te skłaniają do pilnego poszukiwania nowych, dostosowanych do potrzeb, wzorców pedagogicznego działania oraz nowej jakości procesu przywództwa edukacyjnego w szkole, które powinno kłaść coraz większy nacisk na partycypację nauczycieli w kierowaniu szkołą, czyli efektywne włączanie wszystkich nauczycieli i pedagogów oraz całej społeczności szkolnej w podejmowanie decyzji dotyczących realizacji procesu dydaktyczno-wychowawczego.
\end{abstract}

Słowa kluczowe: szkoła, edukacja, wychowanie, przywództwo edukacyjne, lider edukacyjny

\section{Wprowadzenie}

Szkoła to drugie po rodzinie ważne środowisko wychowawcze, będące nośnikiem nie tylko wiedzy, ale również norm, zasad, wartości uspołeczniających. Uczestnic-

* Grażyna Cęcelek - doktor nauk humanistycznych w zakresie pedagogiki (stopień naukowy uzyskany na Uniwersytecie Warszawskim). Autorka i współredaktorka monografii pedagogicznych oraz ponad 100 artykułów naukowych z pogranicza pedagogiki społecznej, opiekuńczo-wychowawczej i resocjalizacyjnej, a także z obszaru edukacji przedszkolnej i wczesnoszkolnej, pedeutologii, doradztwa edukacyjnego, zawodowego i personalnego oraz podejmujących problematykę edukacji permanentnej, e-edukacji i pedagogiki medialnej - opublikowanych w polskich i zagranicznych periodykach i monografiach naukowych. 
two młodych ludzi w procesie edukacji szkolnej umożliwia im przygotowanie się do pełnienia określonych ról społecznych, wykonywania pracy zawodowej, racjonalnego spędzania czasu wolnego. W stronę szkoły skierowane są nadzieje związane z kształtowaniem pożądanych kompetencji społecznych i zawodowych, społecznie akceptowanych wzorców zachowań, umiejętności radzenia sobie w życiu oraz oddziaływania na otaczającą rzeczywistość. Bez uczestnictwa w procesie edukacji szkolnej trudno byłoby przygotować młode pokolenia do świadomego i racjonalnego uczestnictwa społecznego.

Różnorodne zmiany dokonujące się we współczesnej rzeczywistości społecznej i edukacyjnej, ukierunkowane na budowanie gospodarki opartej na wiedzy, generują jednocześnie potrzebę przeorientowania procesu dydaktyczno-wychowawczego realizowanego przez szkołę w kierunku przygotowania młodego pokolenia do efektywnej adaptacji do ciągłych przeobrażeń życia społecznego. Gospodarka oparta na wiedzy stanowi istotny wyznacznik nowoczesnej koncepcji rozwoju szkoły, w której wiedza traktowana jest jako pewnego rodzaju surowiec strategiczny. Priorytetem w takiej rzeczywistości staje się antycypacja przyszłości oraz kształcenie do przeobrażeń zachodzących w każdej dziedzinie społecznego funkcjonowania. Tendencje takie i dążenia stawiają przed współczesną szkołą jako instytucją edukacyjną coraz większe i bardziej złożone wymagania.

Ważnym zadaniem instytucji szkoły jest w związku z tym kształtowanie u wychowanków umiejętności pozwalających nie tylko na przystosowanie się do zmian zachodzących w bardzo szybkim tempie, ale przede wszystkim przygotowanie ich do zetknięcia się z przyszłością, do świadomego jej planowania i kształtowania. Dlatego też środowisko szkolne staje się odpowiedzialne za generowanie edukacji optymalnie przygotowującej wychowanka nie tylko do korzystania z dorobku cywilizacji, ale także do twórczego uczestniczenia w procesach dalszego istnienia i rozwoju oraz umiejętnego kierowania nimi. „Musi to być człowiek na miarę złożonych wyzwań współczesności, mądry, odpowiedzialny, umiejący odnaleźć się w nowych warunkach społeczno-gospodarczych, mobilny, umiejący krytycznie wybierać i umiejętnie korzystać z różnych źródeł wiedzy"1.

Podstawowym warunkiem drogi zmierzającej do uzyskania pożądanej pozycji zawodowej oraz prestiżu społecznego w dobie przyspieszonego postępu technologicznego oraz globalnej konkurencji towarzyszącej egzystencji współczesnego człowieka, staje się antycypacja przyszłości oraz kształcenie do przeobrażeń zachodzących w każdej dziedzinie społecznego funkcjonowania. Tendencje takie i dążenia stawiają przed współczesną szkołą jako instytucją edukacyjną coraz większe i bardziej złożo-

${ }^{1}$ G. Cęcelek, Nauczyciel wobec edukacyjnych wyzwań współczesnej rzeczywistości, [w:] T. Zacharuk (red.), Pedagog - jednej czy wielu dróg?, cz. 1, Pedagog w teorii, Wydawnictwo Akademii Podlaskiej, Siedlce 2005, s. 99. 
ne wymagania ${ }^{2}$. Dokonujące się nieustannie przemiany powinny w związku $\mathrm{z}$ tym znajdować swoje odbicie przede wszystkim w nowej koncepcji kształcenia, formułą których powinna być kreacja edukacji preferująca kształcenie przygotowujące na potrzeby jutra. Antycypacja bowiem przyszłości, „kształcenie do zmian” - to podstawowe czynniki kierunku przemian edukacji w dobie przyspieszonego postępu technologicznego i globalnej konkurencji w wyścigu o lepszą pozycję zawodową i prestiż społeczny.

Potrzeby te skłaniają do pilnego poszukiwania nowych, dostosowanych do potrzeb wzorców pedagogicznego działania, ponieważ konieczność kształtowania nowego typu osobowości, przystosowanego do wymogów współczesnego życia dezaktualizuje tradycyjne formy pracy pedagogicznej. W tym nowym paradygmacie kształcenia i wychowania zmienia się nie tylko rola nauczyciela, który nadal przecież w największym stopniu decyduje o jakości nauczania, ale także pojęcie procesu przywództwa edukacyjnego w szkole, które kładzie coraz większy nacisk na partycypację nauczycieli w kierowaniu szkołą, czyli efektywne włączanie wszystkich nauczycieli i pedagogów oraz całej społeczności szkolnej w podejmowanie decyzji dotyczących realizacji procesu dydaktyczno-wychowawczego.

Niezwykle ważne jest więc systematyczne inicjowanie dyskusji nad teoretycznym i praktycznym znaczeniem przywództwa edukacyjnego w środowisku szkolnym i pozaszkolnym. Konieczny jest nowy model zarządzania szkołą, nowe paradygmaty oraz kultura organizacyjna przywództwa edukacyjnego, a tym samym odpowiednie pożądane kompetencje społeczne dyrektorów oraz wszystkich nauczycieli tworzących nowe, aktywne, twórcze, wspierające środowisko wychowawcze. Według G. Mazurkiewicza ${ }^{3}$, jedynym możliwym podejściem do przywództwa we współczesnej szkole nastawionej na kreowanie uczenia się i konstruowanie wiedzy jest projektowanie tego procesu tak, aby umożliwiał partycypację w nim jak największej liczbie członków danej uczącej się społeczności, przywództwo edukacyjne uzewnętrznia się bowiem przez udział dużej grupy osób i działanie służące uczeniu się.

Konieczne jest więc poszukiwanie wizji szkoły dla nowych potrzeb i celów, które D. Klus-Stańska postrzega jako „budowanie szansy na rozwijanie umiejętności dokonywania osobistych wyborów i brania za nie odpowiedzialności, umiejętności poszukiwania własnych celów i rozwiązań - w miejsce wcześniejszego bezrefleksyjnego przyswajania cudzych, wspieranie odwagi moralnej, a nie wdrażanie do oportunizmu i konformizmu ugody"4.

${ }^{2}$ G. Cęcelek, School as an Institution Helping the Young to Meet Their Future, "Journal of Human Dignity and Wellbeing" 2016, No. 1 (1), s. 54.

${ }^{3}$ G. Mazurkiewicz, Przywództwo edukacyjne - nowy paradygmat zarządzania w oświacie, [w:] S.M. Kwiatkowski, J. Madalińska-Michalak (red.), Przywództwo edukacyjne w teorii i praktyce, Fundacja Rozwoju Systemu Edukacji, Warszawa 2010, s. 127.

${ }^{4}$ D. Klus-Stańska, Dokąd zmierza polska szkoła? - pytania o ślepe uliczki, kierunki, konteksty, [w:] H. Kwiatkowska, T. Lewowicki (red.), Społeczno-kulturowe konteksty edukacji nauczycieli i pedagogów, WSP ZNP, Warszawa 2008, s. 13. 


\section{Rozumienie przywództwa edukacyjnego}

Przywództwo edukacyjne występuje w obszarze sfery edukacji, jest to więc proces, który dotyczy powiązanych czynności nauczyciela i uczniów: nauczania i uczenia się, i w dużym stopniu jest do nich podobny, gdyż wiąże się z dążeniem do wyzwalania $\mathrm{w}$ innych zdolności do jak najlepszego wykonywania zadań, a jednocześnie z poczuciem szacunku dla innych oraz poszanowania ich godności.

Według J. Madalińskiej-Michalak ${ }^{5}$, przywództwo edukacyjne jest procesem dziejącym się w czasie, w którym udział biorą zarówno nauczyciele, uczniowie, rodzice, jak również osoby przewodzące szkole. Na proces przywództwa w szkole mają wpływ nie tylko wzajemne oddziaływania, interakcje podmiotów edukacji, ale również kontekst, w którym ten proces się odbywa, dlatego też obrazując relację między przywództwem edukacyjnym a osiągnięciami uczniów, warto wziąć pod uwagę zwłaszcza model współzależności zachodzący pomiędzy tymi czynnikami. Proces przywództwa edukacyjnego prowadzi do doskonalenia umiejętności uzewnętrzniania potencjału innych uczestników tego procesu przez tworzenie sytuacji umożliwiających wszystkim uczenie się oraz rozwiązywanie problemów. „Tak więc, istotną właściwością przywództwa edukacyjnego jest jego zbiorowy charakter: przywództwo zawsze zachodzi przez interakcje między ludźmi. Wartością autoteliczną przywództwa edukacyjnego jest szeroka partycypacja pracowników w procesie budowania wizji oraz podejmowania decyzji i wprowadzania ich w życie, a przez to branie odpowiedzialności za ich rezultaty"'. Przywództwo edukacyjne dyrektora szkoły charakteryzuje się tym, że ludzie są „prowadzeni” w stronę współpracy tak, aby mogli wspólnie działać w celu osiągania pożądanych celów i realizacji określonych zadań. Przywództwo edukacyjne odnosi się do relacji, w której jej uczestnicy zarówno są tymi, którzy ją „kształtują”, „kształtują się”, jak i są „kształtowani” przez siebie nawzajem?

Ważnym warunkiem zaistnienia przywództwa edukacyjnego jest odpowiednie nastawienie osób, które sprawują formalne funkcje przywódcze wobec własnego stanowiska, wobec siebie, a przede wszystkim wobec innych, ponieważ liderzy działają zawsze w środowisku stworzonym przez ludzi i w kontekście ich doświadczeń, oczekiwań oraz założeń. „Pełnienie funkcji przywództwa edukacyjnego oznacza konieczność wyrobienia wysokiego poziomu samoświadomości i poczucia własnej wartości,

${ }^{5}$ J. Madalińska-Michalak, Skuteczne przywództwo w szkołach na obszarach zaniedbanych społecznie. Studium porównawcze, Wydawnictwo Uniwersytetu Łódzkiego, Łódź 2012, s. 140.

${ }^{6}$ G. Mazurkiewicz, Przywództwo edukacyjne. Odpowiedzialne zarządzanie edukacją wobec wyzwań współczesności, Wydawnictwo Uniwersytetu Jagiellońskiego, Kraków 2011, cyt. za: G. Mazurkiewicz, Przywództwo dla uczenia się. Jak wyjść poza schemat, [w:] S.M. Kwiatkowski, J. Madalińska-Michalak, I. Nowosad (red.), Przywództwo edukacyjne w szkole i jej otoczeniu, Difin, Warszawa 2011, s. 26-27.

${ }^{7}$ J. Madalińska-Michalak, Dyrektor szkoły liderem - inspiracje i perspektywy, Wolters Kluwer, Warszawa 2015. 
ale jednocześnie wycofanie się, zostawienie przestrzeni współpracownikom zarówno na rozwój, jak i pracę oraz sukcesy"s.

Niezwykle ważne jest zrozumienie przez przywódcę, że jego największym sukcesem są współpracownicy twórczy i kreatywni, odpowiedzialni za swoje zadania, którzy bez żadnych zahamowań czy lęku potrafią przedstawić własny punkt widzenia, argumentować, przekonywać oraz uzasadniać swoje stanowisko. Cenną cechą każdego przywódcy, również przywódcy edukacyjnego jest umiejętność refleksji nad własnym postępowaniem, własnymi zasadami, wartościami, przekonaniami oraz priorytetami, która umożliwia zrozumienie ich konsekwencji dla działań innych osób oraz całej społeczności szkolnej i edukacyjnej.

Przywództwo edukacyjne oparte jest na pięciu podstawowych następujących filarach:

- adekwatność: w organizacji z wysokim potencjałem przywódczym panuje przekonanie o sensowności działań, chęć poszukiwania nowych rozwiązań oraz zgoda na ewentualne błędy wynikające $\mathrm{z}$ aktywności, ale z wyłączeniem zachowania nacechowanego lekceważeniem innych;

- uczenie się: dla tworzenia wysokiego potencjału przywódczego niezwykle ważne jest określenie celu działania w sposób wyraźny i jasny, a także akceptowany przez innych, priorytetem natomiast jest uczenie się członków organizacji;

- partycypacja: w organizacji z wysokim potencjałem przywódczym tworzony jest naturalny grunt pod ujawnianie się talentów, tworzenie postaw brania odpowiedzialności za więcej niż niezbędne minimum, gotowość do udziału we wszystkich wydarzeniach związanych z działalnością instytucji;

- służebność: chodzi o tworzenie atmosfery zaufania i wsparcia oraz chęci niesienia pomocy w rozwiązywaniu problemów, o spłaszczenie hierarchii służbowej oraz zdobywanie szacunku i prestiżu nie poprzez stanowisko, ale w relacjach z innymi uczestnikami procesów edukacyjnych;

- różnorodność: w organizacji z wysokim potencjałem przywódczym zauważa się zdolność do korzystania ze wszystkich zasobów, także z odmienności i różnorodności innych uczestników, natomiast panujące zasady autonomii pozwalają owe odmienności traktować jako wzmocnienie, a nie obciążenie.

Obszary te powinny stanowić swoistą inspirację, drogowskaz dla osób pełniących funkcję przywódców, pracujących nad efektywnym rozwojem organizacyjnym. Zagospodarowanie każdego z nich może w istotnym stopniu przyczynić się rozwoju potencjału twórczego placówki edukacyjnej.

\footnotetext{
${ }^{8}$ G. Mazurkiewicz, Przywództwo edukacyjne. Odpowiedzialne..., dz. cyt., s. 28.
} 


\section{Zadania zawodowe dyrektora jako lidera edukacyjnego}

Według B. Daviesa ${ }^{9}$, każda szkoła powinna wypracować swój styl pracy w oparciu o pewną filozofię edukacji, dającą szanse na zmianę sposobów myślenia i działania o szkole, a nie tylko na podstawie zaleceń polityki oświatowej. Jednocześnie autor podkreśla, że zmiany w szkole nie powinny być zależne wyłącznie od pojedynczego lidera, który na początku może stanowić katalizator, wyzwalacz zmiany, ale kierunek ten stopniowo powinien być zaadaptowany, przyjęty i przyswojony przez pozostałych pracowników szkoły. „W kierowaniu szkołą, u podstaw którego tkwi zwrócenie się w stronę myślenia strategicznego, dominuje zatem przywództwo edukacyjne, które prowadzi zarówno do osiągania krótkoterminowych celów, jak i do budowania zdolności i możliwości osiągania celów długoterminowych, które wynikają z przyjętej przez przywódcę i nauczycieli przemyślanej filozofii edukacji i sprzymierzania się z potencjalną rzeczywistością, antycypowania zdarzeń, trendów"10.

Dyrektor szkoły jako lider edukacyjny powinien być zorientowany przede wszystkim na ludzi oraz przyszłość placówki, powinien w związku z tym dbać o motywowanie i zachęcanie pracowników do dalszego rozwoju zawodowego, jak też dbać o stworzenie i realizację wizji, misji oraz strategii szkoły.

Do podstawowych sił napędowych dyrektora szkoły, według A. Cichonia ${ }^{11}$, należą:

- sukcesy pedagogiczne nauczycieli oraz zadowolenie z wykonywanej pracy,

- przyjazne nastawienie środowiska lokalnego do szkoły,

- potencjał tkwiący w nim samym i wiara w możliwość realizacji celów szkoły.

Rola dyrektora w kierowaniu placówką oświatową jest znacząca, jednak współczesne koncepcje przywództwa edukacyjnego podkreślają konieczność angażowania całej społeczności szkolnej w ten proces w oparciu przede wszystkim o zaufanie i odpowiedzialność, ponieważ praca pojedynczych osób, nawet jeśli wydaje się doskonała, nie jest w stanie przynieść takich rezultatów jak praca będąca efektem współpracy i współdziałania wielu podmiotów. „Tradycyjny styl kierowania z elementami autorytaryzmu i dominacji pozbawia samodzielności, uzależnia i zwalnia z myślenia o powodzeniu całości. Szkole, która pracuje w zmiennym otoczeniu, potrzebny jest przywódca, który komunikuje, że wierzy w możliwości nauczycieli, czerpie radość

${ }^{9}$ D. Davies, Leading the Strategically Focused School. Success and Sustainability, Paul Chapman Publishing. A Sage Publication Company, London 2006, cyt. za: J. Madalińska- Michalak, Przywództwo i jego wyzwania w warunkach kultury neoliberalnej, [w:] S.M. Kwiatkowski, J. Madalińska-Michalak, I. Nowosad (red.), Przywództwo edukacyjne w szkole i jej otoczeniu, Difin, Warszawa 2011, s. 52.

${ }^{10}$ J. Madalińska-Michalak, Przywództwo i jego wyzwania..., dz. cyt., s. 52.

11 A. Cichoń, Rola dyrektora szkoły jako lidera, „Edukacja. Studia - Badania - Innowacje” 2001, nr 1, s. 91 . 
z tego, że ludzie się rozwijają, nie widząc w tym zagrożenia dla swojej pozycji" ${ }^{12}$. Rolą dyrektora w procesie wprowadzania zmian w szkole jest dążenie przede wszystkim do tego, by „przydzielane nauczycielom zadania pozwoliły im na przejście od świadomej niekompetencji do świadomej kompetencji, co wymaga w szkole zaufania - zaufania pozwalającego także uczyć się na błędach i dającego podwaliny do budowania nowych wzorców zachowań"13.

W strukturę roli dyrektora szkoły, który chce pretendować do miana lidera szkoły i kształtować jej kulturę organizacyjną, powinny wpisywać się następujące zagadnienia:

- znaczenie i aktualność celu ogólnego, szczegółowego oraz podejścia do zadania: chodzi o wspólne formułowanie przez wszystkich członków zespołu pedagogicznego celów oraz procedur działania; propozycje i sugestie dyrektora nie powinny być odbierane przez pozostałych członków zespołu jako polecenia, ważna jest współpraca oraz swoboda w wyrażaniu własnych myśli i odmiennych poglądów;

- troska o pozostałych członków zespołu i wzajemne zaufanie: dyrektor szkoły jako lider powinien zadbać o dobro wszystkich pracowników szkoły oraz stworzenie atmosfery zaufania i życzliwości, podkreślać wagę osobistej i wspólnej odpowiedzialności osób tworzących zespół, udzielać pozytywnych wzmocnień, wyrażać konstruktywne uwagi, przekazywać pozytywną informację zwrotną, unikać zachowań, które mogą onieśmielać innych, podejmować działania jednoczące zespół;

- skoncentrowanie uwagi na różnorodnych umiejętnościach i ich rozwijaniu: dyrektor szkoły jako lider edukacyjny powinien zachęcać wszystkich członków zespołu do rozwijania różnych umiejętności między innymi przez przydzielanie nowych zadań i ról, w których poszczególne osoby mogą się sprawdzić i zdobyć nowe doświadczenia;

- umiejętność kontaktów z otoczeniem i usuwanie przeszkód: chodzi o przejmowanie przez dyrektora szkoły odpowiedzialności za kontakty ze środowiskiem zewnętrznym oraz za relacje z pozostałymi pracownikami szkoły w zakresie skutecznego przekazywania istoty celu ogólnego oraz celów szczegółowych realizowanego procesu dydaktyczno-wychowawczego w placówce;

- swoboda działań: w określonych sytuacjach dyrektor szkoły powinien potrafić „usunąć się w bok”, dając innym pracownikom możliwość swobodnego działania, prowadzenia dyskusji, czy też koordynowania realizacji istotnych inicjatyw;

${ }_{12}$ B. Tołwińska, Kierowanie szkołą: rola dyrektora - partycypacja nauczycieli, [w:] S.M. Kwiatkowski, J. Madalińska-Michalak, I. Nowosad (red.), Przywództwo edukacyjne w szkole i jej otoczeniu, Difin, Warszawa 2011, s. 108.

${ }_{13}$ J. Madalińska-Michalak, Przywództwo dyrektora szkoły a zmiana i uczenie się nauczycieli we wspólnotach praktyków, „Rocznik Lubuski” 2017, t. 43, cz. 1, s. 224. 
- prawdziwa praca: lider zespołu, tak jak każdy jego członek, powinien angażować się we wspólną pracę w takim samym stopniu i zakresie, jak pozostali pracownicy i odpowiednio do aktualnych potrzeb, nie powinien bazować na delegowaniu pracowników do wykonywania skomplikowanych, nieprzyjemnych zadań, nie powinien obawiać się o utratę własnego prestiżu, nie powinien unikać podejmowania również takich działań, które wiążą się z koniecznością dużego ryzyka osobistego ${ }^{14}$.

Należy zauważyć jednocześnie, że chociaż formalne uprawnienia do kierowania placówką edukacyjną posiada dyrektor, w rzeczywistości szkolnej pojawia się systematycznie wiele różnorodnych, złożonych i zmiennych sytuacji, kiedy podjęcie decyzji przekracza możliwości jednej osoby. Trudne i skomplikowane problemy generowane w środowisku szkolnym nie są łatwe do rozwiązania, a dyrektor nie posiada monopolu na tworzenie dobrych rozwiązań. Dlatego też różnorodne kompetencje i doświadczenia poszczególnych osób mogą stanowić nieocenione źródło korzyści dla efektywności procesów dydaktyczno-wychowawczych. „W nowoczesnych koncepcjach szkoły i kierowania szkołą przywódca jest opisywany jako osoba, która nie uzależnia innych od siebie, nie odbiera wiary w siebie, by jednocześnie pokazać jak wiele on znaczy, jakie osiąga sukcesy. W koncepcjach tych przywódca, dostrzegając wysiłek innych, nie szczędzi słów pochwały, docenia, wspiera, gdy istnieje potrzeba, i pozwala, by pracownicy uwierzyli, że mogą osiągać coraz bardziej ambitne cele"15.

Dlatego też coraz większy nacisk we współczesnych koncepcjach kierowania szkołą kładzie się na partycypację nauczycieli w kierowaniu szkołą, będącą rezultatem tzw. dystrybucji przywództwa, czyli dzielenia się przywództwem polegającego na włączaniu nauczycieli oraz całej społeczności szkolnej w podejmowanie decyzji. Działania takie przyczyniają się do zwiększenia przepływu informacji pomiędzy kierownictwem a pracownikami, co sprzyja lepszemu wykorzystaniu ich umiejętności oraz wpływa na zwiększenie satysfakcji z wykonywanej pracy.

\section{Partycypacja nauczycieli w kierowaniu szkołą}

W rozumieniu tradycyjnym sprawowanie roli przywódcy edukacyjnego było zarezerwowane w całości dla dyrektora szkoły, traktowanego jako mentora kadry pedagogicznej, który miał monopol na jej rozwój oraz osiągnięcie sukcesu, w związku z czym cała odpowiedzialność za podejmowane decyzje spoczywała na nim, a inni pracownicy szkoły mogli czuć się w zasadzie z niej zwolnieni.

Wyzwaniem dla praktyki kierowania w placówce edukacyjnej, wypływającym ze współczesnych koncepcji przywództwa, jest inne rozumienie natury przywództwa

${ }^{14}$ J.R. Katzenbach, D.K. Smith, Siła zespołów. Wpływ pracy zespołowej na efektywność organizacji, Oficyna Ekonomiczna Dom Wydawniczy ABC, Kraków 2001, s. 146-152.

15 B. Tołwińska, dz. cyt., s. 111. 
edukacyjnego. Postulowane rozwiązania w tym zakresie wyraźnie akcentują konieczność większego uczestnictwa nauczycieli w tym procesie, którzy mają być nie tylko realizatorami określonych zadań dydaktycznych, ale powinni przejawiać postawę proaktywną i podejmować nowe role służące skutecznemu kreowaniu rzeczywistości szkolnej. „W celu upowszechnienia takiego modelu w praktyce, zarówno dyrektorzy, jak i nauczyciele powinni otrzymać odpowiednie przygotowanie w procesie kształcenia"16. Dzielenie się przywództwem wymaga bowiem właściwego rozumienia istoty takiego działania oraz pełnego zaangażowania i odpowiedzialności wszystkich uczestników tego procesu. „Podstawowe znaczenie ma łańcuch przywództwa. Nie można stać się wysoce skutecznym dyrektorem, jeśli łańcuch przywództwa nie ciągnie się przez całą szkołę"17.

Warto jednocześnie „chronić” przywództwo, by rola ta nie stała się kolejną odgórnie narzuconą powinnością nauczycieli, ponieważ w sytuacji, gdy stanie się zadaniem zewnętrznie wyznaczonym, może przyczynić się do zmian regresywnych, co byłoby niezwykle niebezpieczne dla placówki edukacyjnej oraz systemu oświatowo-wychowawczego ${ }^{18}$. Należy w związku z tym konsekwentnie docierać do grona nauczycieli z wiedzą o przywództwie, aby przez działania te „uruchomić dobre skojarzenie z nim związane, tj. zaufanie, zaangażowanie, dialog, współpracę, zasady, wizje szkoły itp., a przeciwstawić się automatycznym, potocznym skojarzeniom związanym z władzą, dominacją jednej ortodoksyjnej wizji, odgórnemu sterowaniu, podporządkowaniu"19.

Według J. Madalińskiej-Michalak ${ }^{20}$, inicjowanie i wdrażanie zmian w szkole wymaga szczególnych kompetencji przywódczych ze strony dyrektora szkoły, u podstaw których leży przede wszystkim specjalistyczna wiedza oraz umiejętności i kompetencje społeczne służące realizacji następujących zadań:

- planowanie i wprowadzanie zmian,

- rozumienie uwarunkowań środowiskowych, ekonomicznych i prawnych funkcjonowania oświaty i przywództwa edukacyjnego,

- prowadzenie badań edukacyjnych i implementacji ich wyników w kreatywnych działaniach przywódcy,

- dostrzeganie i formułowanie dylematów etycznych pojawiających się w polu działania lidera oraz poszukiwania optymalnych rozwiązań,

- budowanie zespołu i kierowania zespołem,

16 Tamże, s. 112 .

${ }_{17}$ M. Fullan, Odpowiedzialne i skuteczne kierowanie szkoła, przeł. K. Kruszewski, Wydawnictwo Naukowe PWN, Warszawa 2006, s. 33.

18 A. Korzeniecka-Bondar, Przywództwo w szkole: „powierzchowna retoryka” czy konieczny warunek zmian, [w:] S.M. Kwiatkowski, J. Madalińska-Michalak, I. Nowosad (red.), Przywództwo edukacyjne w szkole i jej otoczeniu, Difin, Warszawa 2011, s. 101.

19 Tamże.

20 J. Madalińska-Michalak, Wspólnoty praktyków a granice uczenia się nauczycieli w szkole. Rola dyrektora szkoły, [w:] A. Minczanowska, A. Szafrańska-Gajdzica, M.J. Szymański (red.), Szkoła. Wspólnota dążeń?, Wydawnictwo Adam Marszałek, Toruń 2016. 
- kształtowanie atmosfery współpracy i kultury organizacyjnej,

- wywieranie wpływu i budowania relacji,

- motywowanie innych do współpracy w dążeniu do osiągania ważnych celów edukacyjnych,

- porozumiewanie się w różnych środowiskach społecznych i zawodowych,

- współpraca ze środowiskiem lokalnym oraz ponadlokalnym.

Wydaje się, że dzielenie się przywództwem, prawdziwa (nie jedynie formalna czy incydentalna) partycypacja nauczycieli w kierowaniu szkołą stanowi dużą szansę na rozwiązywanie trudnych problemów współczesnej szkoły. „Dystrybucja przywództwa" polegająca na przyjmowaniu tej roli nie tylko przez dyrektora, ale również przez nauczycieli prowadzi bowiem do rozwoju zaangażowania i odpowiedzialności wszystkich oraz do ukształtowania przekonania, że „razem można osiągnąć więcej”. Zadania kierownicze powinny być $\mathrm{w}$ związku z tym rozmieszczone w całej strukturze organizacyjnej szkoły, tak aby sprzyjały samodzielnemu podejmowaniu działań przez nauczycieli. „Ich większy udział w procesie kierowania może sprzyjać widzeniu spraw szkoły szerzej, myśleniu o jej powodzeniu całościowo, a nie tylko o sprawach, które dotyczą wyłącznie własnej praktyki za drzwiami klasy. Szkoła może dbać o podnoszenie jakości swojej pracy wtedy, gdy cały personel podejmuje wspólny wysiłek w tym celu"21.

Nauczyciele, którzy nie są włączani w proces przywództwa edukacyjnego, czują się niedoceniani, co może w konsekwencji doprowadzić do izolowania się w środowisku szkolnym, do powstawania braku więzi sprzyjającej wspólnej pracy, wreszcie do poczucia przytłoczenia problemami, do rutyny, a nawet syndromu wypalenia zawodowego.

\section{Podsumowanie}

W świecie współczesnym, w którym bardzo istotnym czynnikiem społecznego funkcjonowania jednostki stała się pomnażana w zawrotnym tempie wiedza, edukacja ma coraz trudniejsze do spełnienia zadania. „Ku niej skierowane są nadzieje związane ze społecznie pożądanymi zmianami mentalności ludzi, ich nawyków, nadzieje na przełamanie stereotypów i schematów myślowych"22.

Zmieniająca się rzeczywistość wymaga bowiem od szkół (od wszystkich uczestników procesu edukacyjnego: nauczycieli, wychowawców, od osób sprawujących funkcje kierownicze w szkole, od rodziców oraz samych uczniów) nowego spojrzenia na dotychczasowe formy oraz sposoby działania we wszystkich płaszczyznach odnoszących się do realizacji szeroko rozumianego procesu edukacyjnego nastawionego na przygotowanie młodych ludzi do aktywnego uczestnictwa we współczesnym świecie.

${ }^{21}$ B. Tołwińska, dz. cyt., s. 107.

${ }^{22}$ W. Korzeniowska (red.), Przemiany edukacyjne w Polsce i na świecie a modele wychowania, Oficyna Wydawnicza Impuls, Kraków 2001, s. 9. 
Nowego wymiaru nabiera rozumienie przywództwa edukacyjnego w szkole, które coraz częściej dostrzegane jest jako istotny czynnik determinujący jakość funkcjonowania szkoły i tym samym efektywność procesu dydaktyczno-wychowawczego. Coraz częściej można spotkać raporty z badań, które omawiają wiele kwestii związanych z relacją: przywództwo-rozwój szkoły. Kategoria przywództwa edukacyjnego pojawia się w badaniach nad szkołą zwłaszcza wówczas, gdy problematyka badań koncentruje się nad nowymi możliwościami dynamizowania rozwoju szkoły stojącej wobec wielu wyzwań związanych ze zjawiskami wynikającymi ze wzrostu zmienności, złożoności, szybkości przekształceń i intensywności oddziaływania na nią ze strony otoczenia.

Ważnym zadaniem przywódcy edukacyjnego jest zapraszanie i zachęcanie do procesu przewodzenia innych pracowników, co służy budowaniu kultury współodpowiedzialności i zarządzania skoncentrowanego na transformacji, przeciwdziałając tym samym odtwarzaniu rzeczywistości czy wypełnianiu obowiązków narzuconych przez biurokrację. „Dlatego przywódcy w edukacji muszą przeprogramować się z nawyku brania odpowiedzialności «za wszystko», na branie odpowiedzialności za jak najlepsze warunki rozwoju i działania współpracowników, tak aby zbudować klimat organizacyjny, który uwolni drzemiące w pracownikach wiedzę, doświadczenie i motywację $e^{23}$. Konieczny jest nowy model zarządzania szkołą, nowe paradygmaty oraz kultura organizacyjna przywództwa edukacyjnego, a tym samym odpowiednie, pożądane kompetencje społeczne dyrektorów oraz wszystkich nauczycieli tworzących nowe, aktywne, twórcze, wspierające środowisko wychowawcze. Niezwykle ważne jest więc systematyczne inicjowanie dyskusji nad teoretycznym i praktycznym znaczeniem przywództwa edukacyjnego w środowisku szkolnym i pozaszkolnym.

Podejście takie umożliwia nauczycielom wychodzenie poza ściśle wytyczoną, wąską rolę dydaktyczną, co wymaga aktywności zamiast bierności, zaangażowania zamiast obojętności, współpracy zamiast rywalizacji. Kształtowanie nawyku oraz konieczności ponoszenia odpowiedzialności za efekty procesu dydaktyczno-wychowawczego jest bardzo ważne również w odniesieniu do uczniów i wychowanków. Aby być w przyszłości samodzielną osobą, potrafiącą krytycznie odnosić się do wielu sytuacji, zauważać problemy, uczeń powinien bowiem brać aktywny udział w procesie edukacji, zamiast reaktywnego, odtwórczego chodzenia po śladach pozostawionych przez innych, co nie sprzyja namysłowi nad własnym byciem w świecie ${ }^{24}$.

Należy mieć oczywiście świadomość, że nie istnieją uniwersalne rozwiązania, pomysły na oświatę oraz sprawowanie przywództwa edukacyjnego, które sprawdzą się w różnych miejscach i kontekstach sytuacyjnych, niełatwo też ocenić szybko i obiektywnie skutki procesów edukacyjnych, ponieważ widoczne są one dopiero w jakości społecznego funkcjonowania wychowanków.

${ }^{23}$ G. Mazurkiewicz, Przywództwo edukacyjne - nowy paradygmat..., dz. cyt., 129.

${ }^{24}$ B. Tołwińska, dz. cyt., s. 105. 
Według M. Dudzikowej ${ }^{25}$, szkoła, która jest świadoma swego potencjału, samoczynnie staje się źródłem procesu zmian nastawionych na podnoszenie jakości edukacji. Przyjęcie takiego założenia eksponuje środowisko szkolne jako miejsce tworzenia i zapewnienia jakości, a także pozwala lepiej zrozumieć rangę procesów wewnątrzszkolnych oraz faktu, że to co się dzieje w szkole, może być barierą lub warunkiem jakości edukacji, zaporą lub wsparciem rozwoju dzieci i młodzieży ${ }^{26}$. „Edukacja bywa obszarem mitów, rytuałów czy niespełnionych obietnic, ale jest też przecież procesem, który pozwala ludziom przekroczyć różnego rodzaju ograniczenia. Przebudzenie przywódców do wspólnego działania może poruszyć lawinę, która doprowadzi do sytuacji, w której to w przedszkolach, w szkołach i na uniwersytetach rodzić się będą ambitne projekty rozwojowe, przełamujące schematy, pomysły i wynalazki technologiczne, kreatywne i innowacyjne rozwiązania problemów"27.

Przedstawione rozważania ze względu na swój zakres pokazują jedynie zarys problematyki przywództwa edukacyjnego we współczesnej szkole, wskazują jednak jednoznacznie na konieczność dalszego zgłębiania tych niezwykle ważnych zagadnień w celu optymalizacji procesu kształcenia i wychowania młodych pokoleń.

\section{Bibliografia}

Cęcelek G., Nauczyciel wobec edukacyjnych wyzwań współczesnej rzeczywistości, [w:] T. Zacharuk (red.), Pedagog - jednej czy wielu dróg?, cz. 1, Pedagog w teorii, Wydawnictwo Akademii Podlaskiej, Siedlce 2005.

Cęcelek G., School as an Institution Helping the Young to Meet Their Future, "Journal of Human Dignity and Wellbeing” 2016, No. 1 (1).

Cichoń A., Rola dyrektora szkoły jako lidera, „Edukacja. Studia - Badania - Innowacje" 2001, nr 1.

Davies B., Leading the Strategically Focused School. Success and Sustainability, Paul Chapman Publishing. A Sage Publication Company, London 2006.

Dudzikowa M., Mit o szkole jako miejscu wszechstronnego rozwoju ucznia. Eseje entopedagogiczne, Oficyna Wydawnicza Impuls, Kraków 2001.

Fullan M., Odpowiedzialne i skuteczne kierowanie szkoła, przeł. K. Kruszewski, Wydawnictwo Naukowe PWN, Warszawa 2006.

${ }^{25}$ M. Dudzikowa, Mit o szkole jako miejscu wszechstronnego rozwoju ucznia. Eseje entopedagogiczne, Oficyna Wydawnicza Impuls, Kraków 2001, s. 138.

${ }^{26}$ I. Nowosad, Od rozwoju szkolnictwa do rozwoju szkoły, [w:] S.M. Kwiatkowski, J. Madalińska-Michalak, I. Nowosad (red.), Przywództwo edukacyjne w szkole i jej otoczeniu, Difin, Warszawa 2011, s. 73.

${ }^{27}$ G. Mazurkiewicz, Przywództwo dla uczenia się. Jak wyjść poza schemat, [w:] S.M. Kwiatkowski, J. Madalińska-Michalak, I. Nowosad (red.), Przywództwo edukacyjne w szkole i jej otoczeniu, Difin, Warszawa 2011, s. 26-38. 
Katzenbach J.R., Smith D.K., Siła zespołów. Wpływ pracy zespołowej na efektywność organizacji, Oficyna Ekonomiczna Dom Wydawniczy ABC, Kraków 2001.

Klus-Stańska D., Dokąd zmierza polska szkoła? - pytania o ślepe uliczki, kierunki, konteksty, [w:] H. Kwiatkowska, T. Lewowicki (red.), Społeczno-kulturowe konteksty edukacji nauczycieli i pedagogów, WSP ZNP, Warszawa 2008.

Korzeniecka-Bondar A., Przywództwo w szkole: „powierzchowna retoryka” czy konieczny warunek zmian, [w:] S.M. Kwiatkowski, J. Madalińska-Michalak, I. Nowosad (red.), Przywództwo edukacyjne w szkole i jej otoczeniu, Difin, Warszawa 2011.

Korzeniowska W. (red.), Przemiany edukacyjne $w$ Polsce i na świecie a modele wychowania, Oficyna Wydawnicza Impuls, Kraków 2001.

Madalińska-Michalak J., Dyrektor szkoły liderem - inspiracje i perspektywy, Wolters Kluwer, Warszawa 2015.

Madalińska-Michalak J., Przywództwo dyrektora szkoły a zmiana i uczenie się nauczycieli we wspólnotach praktyków, „Rocznik Lubuski” 2017, t. 43, cz. 1.

Madalińska-Michalak J., Przywództwo i jego wyzwania $w$ warunkach kultury neoliberalnej, [w:] S.M. Kwiatkowski, J. Madalińska-Michalak, I. Nowosad (red.), Przywództwo edukacyjne w szkole i jej otoczeniu, Difin, Warszawa 2011.

Madalińska-Michalak J., Skuteczne przywództwo w szkołach na obszarach zaniedbanych społecznie. Studium porównawcze, Wydawnictwo Uniwersytetu Łódzkiego, Łódź 2012.

Madalińska-Michalak J., Wspólnoty praktyków a granice uczenia się nauczycieli $w$ szkole. Rola dyrektora szkoły, [w:] A. Minczanowska, A. Szafrańska-Gajdzica, M.J. Szymański (red.), Szkoła. Wspólnota dążeń?, Wydawnictwo Adam Marszałek, Toruń 2016.

Mazurkiewicz G., Przywództwo dla uczenia się. Jak wyjść poza schemat, [w:] S.M. Kwiatkowski, J. Madalińska-Michalak, I. Nowosad (red.), Przywództwo edukacyjne w szkole i jej otoczeniu, Difin, Warszawa 2011.

Mazurkiewicz G., Przywództwo edukacyjne - nowy paradygmat zarządzania w oświacie, [w:] S.M. Kwiatkowski, J. Madalińska-Michalak (red.), Przywództwo edukacyjne $w$ teorii i praktyce, Fundacja Rozwoju Systemu Edukacji, Warszawa 2010.

Mazurkiewicz G., Przywództwo edukacyjne. Odpowiedzialne zarządzanie edukacja wobec wyzwań współczesności, Wydawnictwo Uniwersytetu Jagiellońskiego, Kraków 2011.

Nowosad I., Od rozwoju szkolnictwa do rozwoju szkoły, [w:] S.M. Kwiatkowski, J. Madalińska-Michalak, I. Nowosad (red.), Przywództwo edukacyjne w szkole i jej otoczeniu, Difin, Warszawa 2011.

Tołwińska B., Kierowanie szkoła: rola dyrektora - partycypacja nauczycieli, [w:] S.M. Kwiatkowski, J. Madalińska-Michalak, I. Nowosad (red.), Przywództwo edukacyjne w szkole i jej otoczeniu, Difin, Warszawa 2011. 


\section{The specificity of educational leadership at school and its environment}

Abstract: The school is the second most important educational environment after the family, being a transmitter not only of knowledge, but also norms, principles and social values. Hopes related to shaping the desired social and professional competences of the young generation are directed towards the school.

The school as an institution is constantly changing and evolving, adapting principles and methods of work to the current needs of society. Anticipating the future and educating for transformations taking place in every field of social functioning becomes the priority of the education system.

These needs incline to an urgent search for new patterns of pedagogical activity, tailored to those needs, and new qualities of the educational leadership process in school, which should place more and more emphasis on teacher participation in school management, i.e. the effective involvement of all teachers and educators and the entire school community in undertaking decisions regarding the implementation of the didactic and educational process.

Keywords: school, education, upbringing, educational leadership, educational leader

About the author: Grażyna Cęcelek - doctor of humanities in the field of pedagogy (academic degree obtained at the University of Warsaw). Author and co-editor of pedagogical monographs and over 100 academic articles on the border of social, guardian and educational and resocialization pedagogy, as well as in the field of nursery and early school education, pedeutology, educational, vocational and personal consulting, as well as ones dealing with the issues of permanent education, e-education and media pedagogy - published in Polish and foreign periodicals and scientific monographs. 


\title{
Agnieszka Krawczyk* (iD) https://orcid.org/0000-0003-0211-3132 \\ Uniwersytet Łódzki
}

https://doi.org/10.25312/2083-2923.17/2020_10ak

\section{Skrivnosti Nika Grafenauera jako ujawnianie tajemnic ${ }^{1}$}

\begin{abstract}
Streszczenie: W artykule zaprezentowana została analiza tomiku poetyckiego Nika Grafenauera pt. Skrivnosti. Przywołane zostały ogólne koncepcje dotyczące narracji, które stanowią bazę dla interpretacji utworów ze zbiorku poety. Skrivnosti to zbiór tajemnic, które mogą być odkrywane samodzielnie przez czytelnika, ale też stanowić wsparcie dla wychowawcy pracującego z młodzieżą. Tekst ma na celu zapoznanie polskiego czytelnika z twórczością słoweńskiego poety, wykorzystanie aspektu narracyjnego do analizy utworu poetyckiego, a także pokazanie sposobu wykorzystania utworu poetyckiego w praktycznej pracy pedagogicznej.
\end{abstract}

Słowa kluczowe: Skrivnosti, Niko Grafenauer, poezja słoweńska, literatura dla młodzieży, narracja

\section{Wprowadzenie}

Według Słownika terminów literackich narracja jest „wypowiedzią monologową”, składającą się z serii następujących po sobie zdarzeń. W owych zdarzeniach uczestniczą bohaterowie, funkcjonujący w jakimś środowisku, które umożliwia im odgrywanie określonych ról ${ }^{2}$. Zatem aby móc określić dany utwór jako narracyjny, należy w nim rozpoznać kolejne wydarzenia, bohatera (lub bohaterów) i jego (lub ich) środowisko.

* Agnieszka Krawczyk - magister filologii słowiańskiej i pedagogiki; asystent w Katedrze Badań Edukacyjnych Wydziału Nauk o Wychowaniu, Uniwersytet Łódzki. Zainteresowania naukowe: pedagogika międzykulturowa, kultura, kultura żydowska, narratologia, metody badawcze, badania jakościowe, literatura, literatura dla dzieci i młodzieży.

${ }^{1}$ Dziękuję prof. Danucie Urbaniak-Zając za merytoryczne wskazówki. Ta część artykułu, która dotyczy analizy utworów poetyckich, powstała na podstawie pracy magisterskiej napisanej pod kierunkiem prof. Zdzisława Darasza pt. Obrazy dzieciństwa, metafory życia. O poezji Nika Grafenauera, Łódź 2009.

${ }^{2}$ M. Głowiński i in. (red.), Słownik terminów literackich, Ossolineum, Wrocław 1989, s. 303. 
Niezbędne jest również współistnienie trzech komponentów strukturalnych, do których należą: początek, dzięki któremu odbiorca poznaje zamiary bohatera; rozwinięcie, w którym przedstawiane są sposoby pokonywania komplikacji na drodze do celu; a także zakończenie lub jego obietnica ${ }^{3}$. Ramy teorii narracji wyznaczane są przez trzy komponenty. Pierwszy z nich to tekst narracyjny, w którym podmiot przedstawia odbiorcy swą opowieść. Medium może tu być dowolne, na przykład język, obraz, dźwięk, budowla lub ich dowolna kombinacja. Drugi komponent stanowi opowieść, która wypełnia treścią tekst narracyjny, a także stanowi podstawę dla trzeciego komponentu, czyli dla fabuły. Na nią z kolei składają się wydarzenia doświadczane lub wywoływane przez bohatera, ułożone w sposób logiczny i chronologiczny ${ }^{4}$. Podsumowując, w utworze narracyjnym lub takim, który posiada choćby aspekt narracyjny, powinny występować trzy trójjedności: kompozycyjna/treściowa, strukturalna i teoretyczna. Aspekt narracyjny odnaleźć można w utworach poetyckich, czego przykładem jest zbiorek Skrivnosti autorstwa słoweńskiego poety Nika Grafenauera ${ }^{5}$.

Skrivnosti ${ }^{6}$ to zbiór tajemnic, które mogą być odczytywane na wielu płaszczyznach. Trudno jest wyznaczyć te płaszczyzny odgórnie, określić drogę czytania albo narzucić czytelnikowi konkretny sposób interpretowania tajemnic. Można je zgłębiać bezpośrednio, tak jak zaproponował autor; można wybierać najbliższe sobie wartości czy przeżycia i czytać tylko o nich, pomijając te dalsze; można się zapoznać najpierw z tymi, które wywołują negatywne emocje, i od nich przejść do tych, które wywołują pozytywne. Można też samemu wybrać wiele innych ścieżek, które prowadzą do poznania...

Omawiany tomik wierszy jest ostatnim zbiorem poezji dla dzieci wydanym przez Nika Grafenauera. Skrivnosti to wiersze zbudowane z cztero- lub pięcio-, względnie sześciowersowych strof z rymami krzyżowymi. Stanowią most łączący w twórczości Nika Grafenauera poezję dla dzieci z poezją dla dorosłych. Skierowane są do starszych dzieci i młodzieży, ale również dorosły czytelnik znajdzie w nich aktualne dla siebie treści. Poeta podejmuje w nich próbę zapoznania małego czytelnika ze sprawami trudnymi do zrozumienia przez młody umysł. Istotne w utworach $\mathrm{z}$ tego zbiorku jest przedstawienie skomplikowanych spraw za pomocą gry językowej. Dzięki nim czytelnik może zrozumieć zarówno samego siebie, jak i innych ludzi, gdyż o tym, kim jest człowiek w głębi siebie, można się dowiedzieć, poznając niewidoczne dla oka

${ }^{3}$ P. Nowak, Pragmalingwistyka a narracja: tożsamość, kooperacja, sprzeczność, [w:] J. Wasilewski (red.), Narracje w życiu. O grupie i jednostce, Instytut Dziennikarstwa Uniwersytetu Warszawskiego, Warszawa 2016, s. 200; K. Wasilewska, „Ja” w autonarracji o pierwszym macierzyństwie, [w:] J. Wasilewski (red.), dz. cyt., s. 171-172.

${ }^{4}$ M. Bal, Narratologia. Wprowadzenie do teorii narracji, Eidos Wydawnictwo Uniwersytetu Jagiellońskiego, Kraków 2012, s. 3-4.

${ }^{5}$ Więcej nt. Nika Grafenauera pisałam w: A. Krawczyk, Bohatera literackiego droga przez życie. Na podstawie utworu „Pedenjped” Nika Grafenauera, [w:] M. Jurkowska, D.O. Stankiewicz, M. Wojtowicz (red.), Dziecko jako podmiot poznania, Uniwersytet w Białymstoku, Białystok 2016, s. 37-38.

${ }^{6}$ N. Grafenauer, Skrivnosti, Založba Borec, Ljubljana 1990. 
krajobrazy jego wnętrza. Dominują w nich tajemnica, strach, miłość, wspomnienia $i$ inne trudne do wypowiedzenia sprawy ${ }^{7}$. Wiersze te nie mają na celu upoetyzowania ludzkiej egzystencji czy sławienia poszczególnych wartości. Dają natomiast mniej lub bardziej poetyckie informacje na temat spraw uczuciowych, społecznych, etycznych etc. Ponadto pobudzają do dodatkowych refleksji na tematy poruszone w poszczególnych wierszach. Mogą również być bodźcem do dyskusji z młodzieżą na temat wartości przez nią wyznawanych.

Jak już wspomniałam, wiersze zebrane w tym zbiorku można odczytywać na wiele sposobów, rozumiejąc Skrivnosti jako grę skojarzeń, wartościowanie tajemnic i wyjaśnianie niewyjaśnionego. W niniejszym artykule skoncentruję się przede wszystkim na pokazaniu pierwszego sposobu odczytania tajemnic. Cele artykułu są następujące: [1] zapoznanie polskiego czytelnika z twórczością Nika Grafenauera, [2] wykorzystanie aspektu narracyjnego do analizy utworu poetyckiego, [3] pokazanie sposobu wykorzystania utworu poetyckiego w praktyce pedagogicznej.

\section{Tajemnice jako gra skojarzeń}

Gra skojarzeń jest zabawą lubianą przez dzieci młodsze i starsze, a także przez młodzież. Bywa też pomocna dorosłym - nie tylko w momentach, gdy wychowawca nie ma pomysłu na przeprowadzenie innej zabawy, ale i jako bodziec do przeprowadzenia dyskusji z dziećmi i młodzieżą na trudne (również dla dorosłych) tematy. Wyjaśnienia dzieciom wartości można dokonać w sposób słownikowy, ale wtedy trudno jest się odwołać do dziecięcych uczuć lub przeżyć, a przede wszystkim trudno sprawić, by dziecko zrozumiało dane pojęcie. Dlatego najlepiej wykorzystać Skrivnosti jako narzędzie do dyskusji nad własnymi odczuciami i doświadczeniami związanymi z odkrywaniem tajemnic.

Tajemnica $\left(\right.$ skrivnost $^{8}$ ) przez Wielki słownik języka polskiego objaśniana jest jako „wiadomość, sprawa, fakt, których nie powinno się rozgłaszać, ujawniać ogółowi”. Jest to sekret, który nie może wyjść na jaw, a także „jakaś zagadkowa, niezbadana

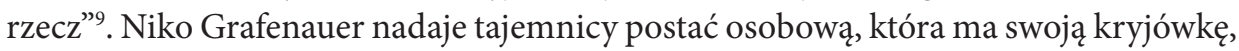
umiejscowioną gdzieś daleko i niedostępną ludzkiemu wzrokowi. Dalej informuje, że to niewidzialne miejsce znajduje się najczęściej na dnie ludzkiego serca, co ma wydźwięk symboliczny. Serce, czyli miejsce, w którym przechowujemy nasze najintymniejsze i najpiękniejsze uczucia, przeciwstawiane rozumowi, który często je niszczy logicznym myśleniem. Wiersz zawiera przestrogę, która ma uczulić odbiorców na

${ }^{7}$ I. Skasida, Mladinska književnost med literarno vedo in književno didaktiko, Založba Obzorja, Maribor 1994, s. 207.

${ }^{8}$ W nawiasach przedstawiam słoweńskojęzyczne odpowiedniki słów oznaczających poszczególne tajemnice.

9 B. Dunaj (red.), Wielki słownik języka polskiego, Buchmann, Warszawa 2009, s. 703. 
wagę tajemnicy oraz podniosłość aktu jej powierzania. Ponadto dziecko dowiaduje się, że tajemnicą można się podzielić tylko z osobą wyjątkową i godną zaufania, a także tego, że tajemnica jemu powierzona powinna być dla niego świętością, której nie wolno nikomu zdradzić.

Z tajemnicą może się skojarzyć strach (strah), czyli naturalna reakcja na coś nieodgadnionego, nieznanego i niepewnego. Według słownika strach jest definiowany jako emocja, która stanowi odpowiedź na poczucie zagrożenia, a także jest „trwogą, lękiem, przerażeniem, przestrachem" ${ }^{10}$. Natomiast autor zaczyna od znanego przysłowia głoszącego, że „strach ma wielkie oczy”. Strach najlepiej widzi, gdy jest ciemno. Wedy dziecko ma większe pole do spuszczenia z wodzy fantazji i do wyobrażania sobie najstraszniejszych rzeczy. Oczywiście, nie chodzi tylko o ciemność, którą można uzyskać, przez zgaszenie światła, ale i o ciemność, jaką jest brak wiedzy na dany temat.

W podsumowaniu wiersza, czyli w ostatniej strofie, autor przedstawia strach w ludzkiej postaci. Strach również się boi, a kiedy dopada go przerażenie, staje się bezsilny. Z powodu bezsilności zaczyna się złościć, przez co z kolei robi się cały czerwony. Gdy zobaczy swój wygląd, zaczyna się śmiać sam z siebie. Może to być przestroga, by nie poddawać się strachowi, ale w momencie gdy się pojawia, działać dalej, śmiać się mu w twarz i nie dać się mu pokonać.

Ze strachem kojarzy się myśl (misel). To właśnie przez nagromadzenie negatywnych myśli często dopada człowieka strach. Można sobie wyobrazić zbyt wiele rzeczy i nadać im tragiczny przebieg. Myśl może być różna. Według słownika jest ona „przedmiotem, obiektem, tworem myślenia”, a także „ideą, koncepcją”, która organizuje „wokół siebie treści szczegółowe”. Myśl to także „pomysł, zamiar, plan”11. Słownikowa definicja odbiera myśli wrażliwość i emocjonalność, którą jej przypisuje poetycka wrażliwość Nika Grafenauera. Autor w pierwszej strofie podaje człowiekowi neutralny opis myśli, przedstawiając je na zasadzie definicji. W dwóch kolejnych znajdujemy opis danego obiektu jako groźnego zjawiska, z którym trudno sobie poradzić i który łatwo może nas pokonać. Jednak młody czytelnik nie jest pozostawiony sam sobie z tą trudną sytuacją, lecz otrzymuje wskazówkę o słabościach ciemnych myśli, i jeśli wykorzysta je odpowiednio, staną się one jego asem w rękawie. Ponadto według poety myśl jest oddalona, sama „ciska się” do głowy. Nie musi ona być ciemna, przesłaniająca czoło gradowymi chmurami, może rozświetlać umysł i dawać nadzieję. Jednakże może się zdarzyć, że coś nam przysłoni ciemną myśl, i wtedy zachmurzy się czoło, a człowiek pogrąży się w smutku i zatopi we wspomnieniach.

I tym sposobem łatwo jest przejść do skojarzenia ze wspomnieniem (spomin), które zostało już wywołane przez myśl. Jak podaje słownik, wspomnienie to „wywołany w myślach obraz zdarzeń, przeżyć z przeszłości”. Może to również być utwór literacki, zawierający opisane przez autora przeszłe zdarzenia, w których brał udział.

\footnotetext{
10 Tamże, s. 667.

11 Tamże, s. 332.
} 
Wspomnienie to także „przedmiot, znak pozostały po czymś minionym, już nieistniejącym, pamiątka oraz napomknięcie o czymś od niechcenia"12. Natomiast Niko Grafenauer twierdzi, że wspomnienie nie jest ograniczone żadnym wymiarem: czasu czy przestrzeni, jest zwierciadłem o nieograniczonej pojemności. Zgodnie z definicją słownikową pisze, że we wspomnieniach najbardziej żywa jest przeszłość, ale też zawierają one elementy przyszłości, która jeszcze jest przed nami. Czas przeszły możemy skropić żywą wodą ${ }^{13}$, a wtedy przeżyjemy go na nowo.

Skoro wspomnienie nie ma żadnych ograniczeń, to według Nika Grafenauera nie ma też „czarnego dna”. Może natomiast mieć „ciemne zapomnienie”, co jest charakterystyczne dla ludzkiego umysłu. Rzadko się zdarza, żeby człowiek przechowywał w swej pamięci dokładną matrycę przeszłości, wszystkie wspomnienia wraz z upływem czasu ulegają zniekształceniom i przeobrażeniom. Czasami nawet mogą one zgubić swoją cudowną moc i całkowicie zaginąć w otchłani umysłu.

Dzieci i młodzież najczęściej przechowują wspomnienia radosne i pozytywne. Dlatego też pierwszym skojarzeniem ze słowem „wspomnienie” bywa w umysłach młodych ludzi szczęście (sreča), które przez autorów słownika jest określane jako „sytuacja, gdy wszystko układa się dobrze, zgodnie z pragnieniami, oczekiwaniami, pomyślność, powodzenie” lub „poczucie radości, stan euforii, upojenia, zadowolenia z czegoś” ${ }^{14}$. Niko Grafenauer twierdzi, że pierwszą oznakę szczęścia można zobaczyć w oczach, co jest potwierdzeniem powiedzenia, że oczy są zwierciadłem duszy. Dzięki szczęściu nawet najmniej pogodny dzień staje się dobry i każdą chwilę wypełnia śmiech. Radość przenika całego człowieka, jego gesty, mimikę, całe ciało. Samo szczęście nigdy nie jest smutne i nie przeżywa trosk, tylko czasami bywa ledwo zauważalne, skryte w minionym czasie (co stanowi kolejny dowód słuszności skojarzenia szczęścia ze wspomnieniem).

Szczęście jest ludziom niezbędne do życia, jeśli nagle odwróci się od nich, trudno im będzie poradzić sobie z nową sytuacją, na oczy padnie im smutek i przysłonią je ciemne chmury. W ostatniej strofie ukazuje się prawdziwe, podwójne oblicze szczęścia. Pierwszą swoją twarz odsłania ono wtedy, gdy jest przez ludzi doceniane i pożądane, gdy wszystko dzieje się po ich myśli, gdy czują się nim przepełnieni i mogą przenosić góry. Drugie oblicze natomiast pokazuje się wtedy, gdy szczęście odwraca się od ludzi, i nie wiadomo, jak je przywrócić.

12 Tamże, s. 792 .

13 Żywa woda znana $\mathrm{z}$ folkloru cechowała się ponadnaturalnymi właściwościami: dodawała sił i odwagi, leczyła rany, wyzwalała ludzi zaklętych w kamienie, wskrzeszała umarłych. Por. S. Ciszewski, Krakowiacy. Monografia etnograficzna, t. 1, Nakładem Autora, Kraków 1894, s. 110; M. Eliade, Sacrum i profanum. O istocie religijności, przeł. R. Reszke, Wydawnictwo KR, Warszawa 1999, s. 29; A. Jazowski, Opowieści ludu spiskiego, Ludowa Spółdzielnia Wydawnicza, Warszawa 1967, s. 191; P. Kowalski, Woda żywa. Opowieść o wodzie, zdrowiu, higienie i dietetyce, Towarzystwo Przyjaciół Ossolineum, Wrocław 2002, s. 79; F. Lorentz Teksty pomorskie, Polska Akademia Umiejętności, 1924, s. 739.

14 B. Dunaj (red.), dz. cyt., s. 683. 
Każdy człowiek chciałby być szczęśliwy, wielu pewnie takimi się czuje, dlatego też skojarzeniem ze słowem „szczęście” może być ja (jaz). Według słownika jest to zaimek odnoszący się do mówiącego ${ }^{15}$. Natomiast „ja” według Nika Grafenauera to obiekt dojrzewający przez całe życie, zapatrzony w siebie i swoje możliwości, skrywający swoje sprawy przed otoczeniem, eksponujący te, którymi można się pochwalić. Ja nigdy nie może być sobą, jeśli jest samo, człowiek może poznać samego siebie dopiero podczas kontaktów społecznych z innymi ludźmi. Natomiast każdy człowiek, czyli każde ja, jest w swoim wnętrzu rozdarte na dwie połowy: na wyobrażenie o samym sobie, na to, jak samo siebie widzi i jakim chciałoby być, oraz na swój prawdziwy (?) obraz.

Asocjacją do słowa „ja” może być, oprócz słowa „szczęście”, również słowo samotność (samota), czyli „odczuwany stan braku towarzystwa bliskiej osoby, opuszczenia przez innych”, a także „przebywanie w odosobnieniu bez rodziny, przyjaciól” ${ }^{16}$. Stan ten nasila się szczególnie w okresie dojrzewania, kiedy nastolatek czuje się niezrozumiany przez wszystkich: rodziców, nauczycieli, rówieśników. Dzieje się tak nie tylko w przypadku młodzieży odrzuconej przez grono rówieśnicze czy pochodzącej $\mathrm{z}$ dysfunkcyjnych rodzin, ale nawet w sytuacji osób akceptowanych przez otoczenie i wspieranych przez rodziców. Zjawiskiem naturalnym dla tego okresu jest silne poczucie indywidualności, odrębności i niezależności. Młodemu człowiekowi często towarzyszą myśli, że nikt nie jest w stanie pojąć jego potrzeb i racji, nikt nie wie, co on przeżywa, czuje i myśli.

Niko Grafenauer informuje nas, że samotność nie lubi być niepokojona, unika ciekawskich oczu, a najlepiej czuje się w cichym zakątku odosobnionym od reszty świata. Kiedy znajdzie się w takim miejscu, może się w spokoju zastanowić nad własnym losem i oddać się rozmyślaniom. Wtedy staje się najbardziej przestrzenna, a nawet piękna.

Samotność z własnej woli zamyka się w sobie, dlatego czuje się niekomfortowo, gdy ktoś próbuje dostać się do jej samotni. Kiedy zmęczy się własną samotnością, ucieka ze swojego azylu i szuka kontaktu z ludźmi. Tak też jest z każdym człowiekiem, nie tylko tym wchodzącym w dorosłość. Potrzebuje on chwili samotności, refleksji, zatrzymania się i odpoczynku od ciągłego pędu we współczesnym świecie, nie ma wtedy ochoty na spotkania z rówieśnikami, ale gdy w spokoju przemyśli wszystkie sprawy i nacieszy się własnym towarzystwem, wychodzi na spotkanie innym.

Przykładem skojarzenia na zasadzie kontrastu jest para samotność - miłość. Miłość (ljubezen), zwłaszcza ta szczęśliwa i spełniona, nie jest nigdy samotna. Ale nawet miłość platoniczna jest sprzeczna z samotnością, gdyż wtedy w życiu zakochanego człowieka gości myśl o obiekcie uczucia. Słownik określa miłość jako „głębokie uczucie do drugiej osoby, połączone zwykle z silnym pragnieniem stałego obcowania z nią

\footnotetext{
15 Tamże, s. 194.

16 Tamże, s. 622.
} 
i chęcią obdarzenia jej szczęściem, któremu towarzyszy pociąg fizyczny do osoby będącej obiektem tego uczucia”. Jest to również „silne przywiązanie do kogoś”. Uczucie to może odnosić się nie tylko do ludzi, ale też do zwierząt, miejsc lub społeczności. Słowo „miłość” może też służyć do określenia osoby „kochanej przez kogoś” lub obiektów materialnych i bytów abstrakcyjnych ${ }^{17}$. Niko Grafenauer pisze, że miłość rodzi się ukradkiem, żyje rozjaśnionym spojrzeniem i cicho rośnie. Miłość, tak jak szczęście, jest widoczna w oczach i w spojrzeniu, a oprócz tego trzyma różę w dłoniach. Róża już przez starożytnych Greków uznawana była za symbol Afrodyty, bogini miłości. Według mitów róża powstała wraz z Afrodytą z piany morskiej oraz krwi, która pojawiła się na stopie bogini, gdy ta biegła na spotkanie swojego kochanka Adonisa. Inne mity podają, że róża powstała z krwi Adonisa rozszarpanego przez dziki ${ }^{18}$.

Niko Grafenauer przypisuje miłości nadnaturalne zdolności: nie stąpa ona po ziemi, lecz unosi się w obłokach. Ponadto cieszy się drobnymi znakami wypisanymi na szkolnych ławkach. Poeta w tym wierszu dodaje powagi młodzieńczej miłości, uznaje ją za dojrzałą, co jest ważne dla nastoletniego czytelnika, któremu dorośli często odbierają prawo do poważnych uczuć, bagatelizując je.

Ostatnia, przywołana wyżej, strofa stanowi przejście do następnego skojarzenia, jakim jest pocałunek. Odwieczny symbol miłości, który słownik definiuje jako „dotknięcie kogoś ustami dla wyrażenia swoich uczuć"19. Niko Grafenauer przedstawia pocałunek jako utkany z delikatnego uczucia, łagodnie przekazywany w ukochane usta. Przez usta łączymy się dzięki niemu z ukochaną osobą, na skutek czego czas i wszystko wokół się zatrzymuje i przestaje być ważne, a dusza, wypełniona radością, rośnie. Pocałunek jest również miernikiem miłości, a proces mierzenia może trwać w nieskończoność. Zamyka on zakochane oczy, swoje korzenie ma w sercu i nigdy nie kończy się bez bólu. Ostatnią strofą autor sprowadza czytelnika na ziemię przez przywołanie rzeczywistości, która każe zakochanym rozstać się na jakiś czas i zająć obowiązkami.

Od pocałunku drogą skojarzeń można przejść do pożądania (slast). Znaczenie podawane przez słownik wiąże się z odczuwaniem „wielkiej ochoty na coś” albo „silnego pociągu fizycznego w stosunku do kogośn ${ }^{20}$. Natomiast według Nika Grafenauera pożądanie jest drżeniem dotykającym duszy, wzbudzanym za pomocą delikatnych dotknięć dłoni. Pożądanie unosi nas bardzo delikatnie, lecz najpiękniejsze jest to, które dojrzewa w gorzkich łzach. Ponadto nie ma ono końca, mimo iż trwa zaledwie kilka chwil.

17 Tamże, s. 316-317.

18 P. Grimal, Słownik mitologii greckiej i rzymskiej, Zakład Narodowy im. Ossolińskich, Wrocław 2008, s. 6-7, 220; Oxford - Wielka Historia Świata. Cywilizacje Europy. Anglia - Słowianie. Cywilizacje Australii i Oceanii. Papuasi, t. 13, Polskie Media Amer.Com, Poznań 2006, s. 73.

19 B. Dunaj (red.), dz. cyt., s. 468.

20 Tamże, s. 511. 
Pożądanie, jak i wszystkie aspekty miłości, kojarzy się nastolatkom z pięknem. Piękno (lepota) definiowane jest przez słownik jako „zespół cech wywołujących przyjemne wrażenia estetyczne; szczególna wartość moralna" ${ }^{21}$. Niko Grafenauer informuje, że piękno pokazuje się w towarzystwie uczuć. Dzięki niemu dusza rozkwita jak róża. Jak i w poprzednich wierszach następuje tu personifikacja doznania zmysłowego, nadanie mu wysokiej rangi. W rozbawionych oczach Piękna widoczne jest błyszczące oczarowanie, które nigdy nie otrzeźwieje. Piękno zdaje się być pijane szczęściem, przepełnione radością, jest najwyższą formą miłości, gdyż kochający lub kochany człowiek zawsze jest piękny.

Od piękna nietrudno przejść do tańca (ples), podczas którego ludzie zapominają o wszystkim, czują się piękni, wolni i przepełnieni radością. Taniec to „,rytmiczne ruchy i kroki, skoordynowane z muzyką, ale też utwór muzyczny, przy którym można tańczyć" ${ }^{\prime 2}$ - jak głosi słownik. Natomiast jako wyjaśnienie tajemnicy taniec jest lotem wykonywanym przy pomocy skrzydeł, ruchem i marzeniem wznoszącym do nieba, łączącym nas końcami palców z ziemią. Dryfuje zawieszony w powietrzu, sam sobą oczarowany, krąży wokół własnej osi. Sam sobą jest zajęty, nie potrzebuje publiczności. Wplątany w welon $\mathrm{z}$ lekkich piór lub jako kokon utkany z mgieł wychodzi na spotkanie nowego dnia. W ostatniej strofie dostrzegalne jest nawiązanie do wartości piękna.

Taniec swoją zmysłowością doprowadza nas do tęsknoty (hrepenjenje), która określana jest jako „uczucie cierpienia, żalu z powodu rozłąki z kimś, utraty kogoś [...] pragnienie zobaczenia kogoš". Może to też być „silne pragnienie osiągnięcia czegoś” ${ }^{23}$. Tęsknota może być: „bezbrzeżna, nieopisana, niewypowiedziana, straszna”, może też być tęsknotą za: „rodziną, dziećmi, krajem”, a nawet można „być chorym z tęsknoty; konać, usychać, umierać z tęsknoty"24. Jednakże Niko Grafenauer pokazuje nam bardziej wyrafinowaną i zmysłową tęsknotę. Otóż sama tęsknota jest rozdarta w bezkresie, tępym wzrokiem wpatrzona w horyzont, oddana swojej czynności całym sercem i rozumem, nie jest uwięziona, nie cierpi, lecz zza szeroko otwartych oczu rzuca tęskne spojrzenie. Codzienność nieustannie próbuje ją zamknąć w swoich siwych pajęczynach czasu, gdyż wie, że wraz z jej stratą zagubi homeostazę i zaburzy porządek świata. Tęsknota zawieszona jest bezwładnie w powietrzu, niczym tęcza nieosiągalna dla ludzkich dłoni. Jednak czasami swoje skrzydła rozwija z niewielką siłą, jakby były złamane lub pogniecione, nachodzi ją wtedy przeczucie końca lub nawet śmierci.

Cały opis tęsknoty przepełniony jest swobodą daną temu uczuciu. Tęsknota jest swobodna, nikt ani nic jej nie ogranicza, nic jej nie narzuca reguł, nie obowiązują jej żadne normy. Dlatego też od tęsknoty można bezpośrednio wyjść do wolności

21 Tamże, s. 456.

22 Tamże, s. 705.

23 Tamże, s. 712.

${ }^{24}$ Hasło „tęsknota”, [w:] W. Doroszewski (red.), Słownik języka polskiego, https://sjp.pwn.pl/ doroszewski/tesknota;5507607.html [dostęp: 25.08.2019]. 
(svoboda), którą stanowi „określone prawo obywateli do czegoś wyznaczone przez dobro powszechne, interes społeczny i porządek prawny” lub bywa określana jako „niezależność, niezawisłość, swoboda, samodzielność” ${ }^{25}$. Natomiast w ujęciu Nika Grafenauera wygląda to nieco inaczej: wolność nie może być zamknięta żadnymi granicami, a gdy te zostaną wykreślone, człowiek zaczyna za nią tęsknić. Ulubioną jej kryjówką jest ciemność, gdyż wolność niejednokrotnie bywa kojarzona z samotnością. Osoba samotna jest wolna - gdy otaczają ją bliscy, nie ma miejsca na pełną swobodę, gdyż wtedy zawsze są na człowieka nakładane różne obowiązki i powinności. Ale osoba obciążona zobowiązaniami wobec bliskich może się w tej sytuacji odnaleźć i czuć się swobodnie, jeśli swoje obowiązki podejmie w sposób świadomy i przemyślany. Wolność według Nika Grafenauera jest najpełniejsza, gdy zostanie obdarzona zaufaniem.

Natomiast jeśli wolność wyswobodzi się ze wszystkich trudności, w jej bezkresie zatopi się wszystko, czego dosięgnie. Swobodę można ujrzeć duszą, nie zaś oczyma, a sama wolność czuwa nad nami przez cały czas, ukrywając w swoim cieniu ślad śmierci.

Z wolnością, zarówno jej pozytywnym, jak i negatywnym aspektem, kojarzą nam się żywioły. Nie ma chyba bardziej wolnego i swobodnego zjawiska niż one. Mogą przynieść człowiekowi ukojenie, odprężenie, przywołać radosne wspomnienia, ale również sprowadzają wiele zniszczeń i są bezwzględne. Same żywioły określane są jako „siła przyrody i jej przejawy, zwłaszcza potężne, groźne, trudne do opanowania"26. Bywają one utożsamiane z powietrzem, przeciwstawiane ziemi, w wielu religiach i filozofiach łączone lub stawiane w opozycji do ognia, przynoszące podobne ukojenie jak woda oraz oddzielone od niej jedynie linią horyzontu. Niebo (nebo), czyli „to, co postrzegane jako sklepienie Ziemi, przybierające w dzień niebieską barwę; na jego tle można obserwować ciała niebieskie: słońce, księżyc i gwiazdy”. Jest to również „miejsce przebywania Boga, świętych, dusz zbawionych; w niektórych religiach [...]: siedziba bóstw, kraina wiecznego szczęścia”27. Przedstawiane przez Nika Grafenauera jest bezkresnym okiem, a nasz wzrok jego źrenicą. W jego spojrzeniu kryje się delikatny uśmiech, dzięki któremu cały świat ogarniają słoneczne promienie, ale gdy oko nieba zostanie zamknięte, na Ziemię spada noc i ciemność. Chociaż nie każda noc musi być ciemna, zdarzają się również jasne, podczas których czas i przestrzeń się przenikają.

Ziemia (zemlja), czyli „trzecia planeta Układu Słonecznego, ciało niebieskie obiegające Słońce po orbicie eliptycznej; kula ziemska”. Inaczej określana jest też jako „wierzchnia warstwa skorupy ziemskiej; grunt, gleba” lub „obszar własności prywatnej, państwowej, spółdzielczej, przynoszący właścicielowi zysk z uprawy”, jak i „ob-

\footnotetext{
25 B. Dunaj (red.), dz. cyt., s. 787.

26 Tamże, s. 899.

27 Tamże, s. 356.
} 
szar zamieszkany przez grupę etniczną, podniośle: kraj, ojczyzna"28. Ziemia u Nika Grafenauera ma twarde podłoże, a z niebem jest połączona za pomocą gór. Od tysięcy lat pomiędzy nią a niebem buduje się harmonia i porządek świata. Ma dobry kontakt z przyrodą - pomaga roślinom rosnąć i żyć.

Kolejny żywioł to powietrze (zrak) - „gazy otaczające warstwą Ziemię, konieczne do życia"29. Powietrze jest zawieszone w powietrznej przestrzeni, sprawia wrażenie, jakby nie miało żadnej ciężkości. Jest naznaczone wiecznym błyskiem skrzydeł Ikara $\left(\right.$ Ikarska perutnica $\left.^{30}\right)$, co wskazuje na interakcję Nika Grafenauera z innymi utworami literackimi oraz potocznymi zwrotami. Powietrze oddycha pełnymi płucami, czuje przeróżne zapachy, jak w krysztale odbijają się w nim nastroje dnia codziennego. Jak Ziemia stanowiła schronienie dla roślin, tak powietrze jest przestrzenią, z której najchętniej korzystają ptaki. Oprócz tego powietrze wspiera wszystkie tęskne spojrzenia rzucane przez poszczególne żywe istoty. Czasami jednak powietrzu brakuje powietrza lub jest ciężkie jak ołów, gdy następuje obniżenie ciśnienia. Ale jest silne i zawsze wydobywa z siebie kolejne tchnienie, mając świadomość swojej wartości w życiu wszystkich ludzi, zwierząt i roślin.

Woda (voda) przez słownik określona została jako „ciecz bezbarwna, bez zapachu i smaku, rozpowszechniona w przyrodzie, niezbędna do życia; tlenek wodoru, naturalny lub sztuczny zbiornik tej cieczy, np. staw”, ale też „płyn zbierający się w jamach ciała wskutek choroby. Można też tak mówić o «słowach bez treści»" ${ }^{31}$. Natomiast przez Nika Grafenauera określana jest jako ulotna, przyjmująca wiele postaci, czasami pojawia się w nadmiarze i zajmuje dużą przestrzeń, a innym razem jest prawie niezauważalna. Może się ujawnić w sposób delikatny jako łza lub być dostrzeżona przez wszystkich, gdy przybiera postać rzeki. Najpiękniejsza jest jednak wtedy, gdy zajmuje bardzo dużą przestrzeń, stanowiąc morze. Jest jednocześnie stara i młoda, nigdy nie umrze, nawet gdy spada $z$ nieba na ziemię. Woda jest wiecznie żywa, była na świecie, zanim pojawili się ludzie, jest tu nadal i prawdopodobnie będzie, nawet jeśli ludzkość wyginie.

Ostatnim z żywiołów jest ogień (ogenj), czyli „ciepło i światło powstałe w wyniku spalania się ciał, widoczne w postaci płomieni i żaru”; „stos drzewa, chrustu palący się pod gołym niebem”; „strzały z broni palnej”; a także „gwałtowny stan emocjonalny, namiętność, pasja, werwa"32. Niko Grafenauer prezentuje ogień jako rozdzielający czas na dobry i zły, liżący dłoń ziemi (oblizuje zemeljsko dlan ${ }^{33}$ ) swoimi językami zarówno w ciągu dnia, jak i w nocy. Podobnie jak poprzednie żywioły bywa przewrotny - może być delikatny, płochliwy i nieśmiały, a jednocześnie zdradliwy

\footnotetext{
28 Tamże, s. 874-875.

29 Tamże, s. 507.

30 N. Grafenauer, dz. cyt., s. 38.

31 B. Dunaj (red.), dz. cyt., s. 785

32 Tamże, s. 408.

33 N. Grafenauer, dz. cyt., s. 42.
} 
i opanowujący całą przestrzeń. Tak samo jak w przypadku wiersza o powietrzu, tak i tu występuje interakcja $\mathrm{z}$ innymi utworami literackimi. Możemy znaleźć odwołanie do mitu o Prometeuszu, który dał ludziom ogień. Każdy ogień „udomowiony” jest pożądany, a jeśli jest dobrze przewietrzony, dostanie skrzydeł. Wtedy jest pomocny ludziom.

Następnie czytelnikowi przedstawiony jest czas (čas), czyli „okres wydzielony jakimiś wydarzeniami, zjawiskami, wyodrębniona pora”, a także „bezustanny ciąg następujących po sobie chwil, nieustanne trwanie”; „wyszczególniona chwila, moment, data" ${ }^{34}$. Niko Grafenauer podaje, że czas w sposób niewidoczny ubiera się w dzień lub noc, przemyka tuż przed nami w jasnym lub ciemnym odzieniu. Kiedy się spieszy, nie patrzy na nic ani na nikogo, za wyjątkiem zegarka, na który raz po raz zerka. Czas dotyka wszystkiego, co nas otacza, wszędzie zaznacza swoją obecność. Natomiast przy pomocy lat chętnie rzeźbi zmarszczki w ludzkich twarzach. Ząb czasu nieustannie czuwa, obserwuje i narusza wszystkie ludzkie konstrukcje - zarówno ich wnętrze, jak i sferę zewnętrzną. Cały utwór kończy się podsumowaniem stanowiącym aforyzm.

Czas zawsze idzie w parze z życiem (življenje), które słownikowo opisywane jest jako „charakterystyczny dla materii organicznej, ograniczony czasowo stan zachodzenia w organizmie zespołu procesów biochemicznych, takich jak: oddychanie, odżywianie, przemiana materii, wzrost, rozmnażanie się”; „sposób, rodzaj, tryb, jakość bytowania, istnienia”, ale téz „podstawowe potrzeby życiowe, utrzymanie”. Życie to również „temperament, energia życiowa człowieka, werwa” ${ }^{35}$. Według poety samo Życie prowadzi żywot, polegający na tym, że z każdą chwilą go ubywa, wymyka się, przelatuje między palcami niczym piasek zamknięty w dłoni. W wierszu często przeplatają się zwroty typu „życie żyje”. I tak np. życie nie może żyć, gdy stoi w miejscu, gdy zostaje zawieszone na nitce, nie może się rozwijać ani osiągnąć pełni. Czasami trzęsie się ze śmiechu, a czasami ma łzy w oczach. Jest zmienne, niestałe i nigdy nie można być go pewnym. Najpiękniejsze zaś jest wtedy, gdy rozsypuje się przy pomocy żaru na wszystkie strony świata i do ostatniego tchu płonie, co może być zachętą do umiejętnego korzystania z życia, wykorzystywania go na obowiązki, ale też na przyjemności.

Życie człowieka niejednokrotnie bywa utożsamiane z duszą ( $d u s ̌ a)$, która np. w religii chrześcijańskiej określana bywa jako „nieśmiertelna część człowieka «mieszkająca» w jego ciele przez całe życie, a po śmierci prowadząca własny żywot" ${ }^{36}$. Dlatego skojarzenie jednego z drugim bywa dość częste i nieprzypadkowe. Słownik określa duszę jako „właściwości psychiczne człowieka”; „w religii chrześcijańskiej: duchowy pierwiastek istot ludzkich odrębny od ciała, obdarzony nieśmiertelnością”. Inaczej można też powiedzieć, że dusza to „ktoś, kto w jakimś środowisku jest inspiratorem rozmaitych przedsięwzięć, wpływa na innych, pobudza do działań”. Dusza może być

34 B. Dunaj (red.), dz. cyt., s. 73.

35 Tamże, s. 898.

36 Hasło „dusza”, [w:] W. Doroszewski (red.), dz. cyt., https://sjp.pwn.pl/szukaj/dusza.html [dostęp: 25.08.2019]. 
synonimem słowa „człowiek”37. Natomiast tajemnica duszy według Nika Grafenauera tkwi w jej nienamacalności oraz tym, że nie można jej ujrzeć na własne oczy. Poza tym jest bardzo wrażliwa, łatwo ją zranić, a gdy to nastąpi, potrafi dotkliwie boleć. Dusza jest cicha i bezkresna, wszystko, co ją dotyka, skrywa głęboko w sobie. Lecz gdy rozwinie nad światem swoje radosne skrzydła, tęcza z nich powstała rozjaśni każdą stroskaną twarz. Dusza nie zawsze jest pogodna i szczęśliwa, na co wskazuje przedostatnia strofa, ale ten nastrój nie trwa wiecznie, co przekazuje autor w słowach zawartych w ostatniej strofie.

Ostatnie optymistyczne wersy traktujące o duszy mogą przywołać skojarzenie z zabawą (igra), tj. „czynnością wykonywaną dla przyjemności, rozrywki, odprężenia psychicznego i fizycznego”; „tym, co cieszy, bawi, sprawia przyjemność”38. Zabawa zaproponowana przez Nika Grafenauera jest rozpalona swoim rozgorączkowaniem, znajduje się pomiędzy dwoma biegunami. Dlatego też, niczym języczek u wagi, nigdy nie może zaznać spokoju, może być zarazem wszystkim i niczym. W grze, której towarzyszy dobry los, panuje brak nadmierności, nie ma miejsca na koniec. Jeden biegun gry naznaczony jest śmiertelnością, natomiast drugi przepełniony chwilowością. Każdy swoją zabawę rozgrywa bez świadków, a pewnego dnia wszystko wygramy lub przegramy. Ostatnia strofa naznaczona jest destrukcją, pesymizmem. Jeśli będziemy interpretować grę jako życie, możemy ten wiersz porównać do słów wypowiedzianych przez Josepha Conrada: „żyjemy tak jak śnimy - samotnie”.

Po takim odczytaniu ostatnich słów poprzedniego wiersza skojarzeniem nasuwającym się w pierwszej kolejności będzie ból (bolečina). Jest on określany jako „przykre odczucie psychiczne lub fizyczne, doznanie wskazujące na jakieś niedomagania, zaburzenia w funkcjonowaniu organizmu bądź jego uszkodzenie"39. Według poety ból skłania nas do płaczu, czasami wychodzi przez oczy, a czasami boli nas dusza, stanowi żywą ranę w naszym organizmie. Ból wywołany przez miłość rzuca nas do piekła lub wynosi do nieba, natomiast nasza dusza staje się jasna niczym tęcza (mavrica). Czasami chce nas wypalić do cna, piecze, jakbyśmy zostali polani rozgrzanymi kroplami ołowiu. Najdotkliwszy ból to ten wywołany zmysłowością - powoduje on śmiertelny krzyk. Wtedy właśnie ból osiąga największą i najsilniejszą moc. Jednak gdy już ją osiągnie, traci swoje właściwości i zatapia się w mroku. Tutaj został zastosowany zabieg przeciwny do tego, który autor przedstawił w poprzednim wierszu. Ból traci swoje właściwości, kończy się cierpienie i można przypuszczać, że stan psychiczny człowieka zostaje odbudowany, a sam człowiek powoli wraca do dobrej formy.

Sam ból może wywołać silny stres, a z kolei reakcje na stres są zależne od indywidualnych predyspozycji każdego człowieka. I tak jedna osoba może zareagować wycofaniem się, milczeniem czy autodestrukcją, natomiast druga - agresją skierowaną do otoczenia, krzykiem czy złością. Dlatego też ból może wywołać kontrastowe

\footnotetext{
37 B. Dunaj (red.), dz. cyt., s. 111.

38 Tamże, s. 829.

39 Tamże, s. 42.
} 
skojarzenia, a mianowicie krzyk (krik) i milczenie (molk). Krzyk według słownika to „bardzo donośne mówienie, wołanie, wrzask” ${ }^{40}$. Niko Grafenauer określa go jako stan, któremu często towarzyszą łzy, a jego głos jest smutny. Krzyk nie patrzy na to, czy jest dzień, czy noc, może nas dosięgnąć zawsze i wszędzie. Wygląda, jakby wypływał z otwartych i zakrwawionych ran. Czasami może też być cichy, a nawet przybierać postać samej ciszy. Wtedy mówi się o niemym wołaniu o pomoc.

Krzyk nie musi być tylko podszyty bólem i przepełniony cierpieniem. Znany jest również krzyk wywołany radością i spontaniczną reakcją pozytywną, czego brak w przedstawionym utworze. Jednak od takiego przedstawienia, jakie zaprezentował poeta, łatwiej jest przejść do negatywnego milczenia, nie tego zmysłowego, przepełnionego tajemnicą, lecz tego wywołanego właśnie cierpieniem.

„Milczenie - w odniesieniu do człowieka: nieodzywanie się, cisza bez rozmów; brak przekazu wiadomości, nierozgłaszanie jakichś informacji, nieporuszanie jakiejś sprawy, dochowywanie tajemnicy" ${ }^{\prime 1}$. Milczenie jako tajemnica to cisza ukazująca się podczas cichych nocy. Ulega głosowi, lecz prowadzi do braku wypowiedzenia się. Życie próbuje wrzucić do niego ślady światła. Czasami opuszcza swą samotnię i wychodzi na światło dzienne, gdzie staje się głośniejsze i przeradza się w krzyk. Krzyk i milczenie są nierozłączne i chociaż stanowią przeciwieństwo, zawsze idą w parze, a przejście od jednego stanu do drugiego oddziela cienka granica. Wbrew pozorom stany te mogą być nawet ze sobą mylone.

Milczenie będące brakiem reakcji na sygnały z otoczenia może być utożsamiane ze śmiercią (smrt), która również uniemożliwia reagowanie. Słownik opisuje ją jako „ostateczne ustanie czynności życiowych organizmu; chwilę, w której człowiek umiera, przestaje żyć”, może ona też oznaczać pozbawienie życia samego siebie lub kogoś innego ${ }^{42}$. W wierszu śmierć stoi odwrócona do nas plecami i dniem, i nocą. Najbliżej niej jest śmiertelna cisza wraz ze swym ironicznym uśmiechem. Jest niewidoczna i to według autora odróżnia ją od pozostałych tajemnic. Choć i one były niedostępne dla ludzkich oczu, to ona jako jedyna staje się widoczna przez wzrok naznaczony śmiercią. Żyje w mroku luster, zakrytych ciemną zasłoną, na które nie spadnie już żadne tchnienie. Ten fragment wiersza może wskazywać na dialog z ludowymi tradycjami, które nakazywały zasłaniać lustra tuż po śmierci jednego z domowników. Uważano, że jeśli się tego nie zrobi, a dusza zmarłego odbije się w lustrze, to w rodzinie wnet będzie kolejny pogrzeb ${ }^{43}$. Śmierci nikt ani nic nie wybudzi ze snu, a w śmiertelnej ciszy ma ona wiecznie otwarte oczy.

Śmierć to również pustka, strata i koniec wszystkiego. Dlatego też łatwo ją skojarzyć z niczym (nič). Nic, podając definicję słownikową, to „zaimek rzeczowy prze-

40 Tamże, s. 258.

41 Tamże, s. 316.

42 Tamże, s. 696.

43 A. Savanevičienë (Żygiel), Współczesne zwyczaje i obrzędy pogrzebowe na Wileńszczyźnie, http://naszczas2002.tripod.com/048/czas.html [dostęp: 25.08.2019]. 
czący, wraz ze słowem nie, rzadziej bez tego słowa, sygnalizuje nieistnienie obiektu lub zdarzenia o właściwościach określonych w danym zdaniu; rzecz lub osoba niemająca wartości"44. Natomiast poetyckie nic jest pogrążone w nocy, stawia kropkę nad „i” przy odkrywaniu nieznanego. Jest nieznaną stroną tego, co jest znane i widoczne. Dlatego zawsze współtowarzyszy coś i oznacza wszystko, co z nim związane. Nic jest żywe i może samo zasłynąć, a gdy zasłonimy chociaż jedno oko, wtedy będzie dostępne i osiągalne dla nas.

\section{Inne sposoby interpretacji. Podsumowanie}

Wszystkie wiersze znajdujące się w tomiku Skrivnosti zbudowane są na podobnym schemacie kompozycyjnym. Na początku następuje zapoznanie odbiorcy z problematyką danego zjawiska, krótkie wprowadzenie, czym lub kim ono jest, charakterystyka uosabiająca, natomiast ostatnia strofa pokazuje czytelnikowi, że nic nie jest oczywiste. Jeśli dane zjawisko przedstawione było pozytywnie, ostatnia strofa głosi, że posiada ono cechy również negatywne. Jeśli zaś zostało przedstawione negatywnie - końcowe wersy podają pozytywne cechy lub sposoby poradzenia sobie z pesymizmem.

W tomiku, jak już wspomniałam, prezentowane obiekty stanowią dla młodzieży tajemnicę, są niepojęte, choć często przez nią określane. Autor stara się to zaprezentować w sposób przystępny zarówno dla samych odbiorców, jak i pośredników - rodziców, wychowawców. Nie bez znaczenia są obrazki (autorstwa Karela Zelenki), poważniejsze niż w tomikach dla dzieci tworzonych przez Nika Grafenauera, bardziej enigmatyczne. Nie przedstawiają zamkniętej kompozycji, ale tylko jej zarys, nie pojawia się na nich jeden bohater w swoim codziennym otoczeniu. Na tych ilustracjach znajdują się rozsypane elementy, sprawiające wrażenie niepołączonych ze sobą, lub postacie ludzkie - pojedyncze albo występujące parami, a nawet zbiorowo, jak też przedmioty codziennego użytku, zebrane w niecodzienne kompozycje. Dodatek graficzny nie pozostaje bez znaczenia i nie jest przypadkowy - autor wyjaśnia trudne sprawy, obrazek ma pomóc w ich zrozumieniu, lecz jako dopełnienie wiersza ma przede wszystkim skłaniać do refleksji, wzmagać tajemniczość i niepewność.

Niko Grafenauer, przywołując prawdy życiowe, pisze o nich z dziecięcym wręcz zachwytem, przystaje nad każdą wartością, przygląda się jej przez lupę poezji i oddaje w ręce młodego czytelnika. Widzi rzeczywistość z pozycji młodego człowieka, który nie został jeszcze pochłonięty przez pęd świata i wciągnięty w wir obowiązków, nie patrzy na poszczególne zjawiska przez pryzmat doświadczeń społeczno-kulturowych.

Poszczególne wiersze można analizować nie tylko jako grę skojarzeń, przy pomocy której wyjaśniane zostają trudne sprawy. Dobrym sposobem jest też podział na wartości pozytywne (szczęście, miłość, pocałunek, pożądanie, piękno, taniec,

${ }^{44}$ Hasło „nic”, [w:] W. Doroszewski (red.), dz. cyt., https://sjp.pwn.pl/szukaj/nic.html [dostęp: 25.08.2019]. 
wolność, życie, zabawa), negatywne (strach, samotność, ból, śmierć, nic) i neutralne (myśl, wspomnienie, ja, tęsknota, niebo, ziemia, powietrze, woda, ogień, czas, dusza, krzyk, milczenie).

Każdy człowiek może je pogrupować na własny sposób: pod kątem osobistych potrzeb, przeżyć, doświadczeń życiowych etc. Jest to kolejny pomysł na przeprowadzenie rozmowy z podopiecznymi. Wychowawca może rozdać kartki i mazaki, a następnie poprosić dzieci, by z rozsypanki wyrazowej ułożyły taki schemat wartości, jaki jest im najbliższy. Później nastąpi odczytanie przez każdego uczestnika zajęć swojej propozycji oraz krótkie wyjaśnienie znaczenia poszczególnych wartości. W ten sposób wychowawca zorientuje się, co jest najważniejsze dla jego podopiecznych i do których elementów ze sfery emocjonalnej odnosić się podczas kolejnych zajęć. Może im również przedstawić propozycję rozumienia poszczególnych terminów zaprezentowaną przez Nika Grafenauera. Za pomocą poszczególnych utworów wychowawca może nadać znaczenie młodzieńczym odczuciom, emocjom i wartościom, które często są bagatelizowane przez dorosłych.

Maria Reut zwraca uwagę na to, że w edukacji i wychowaniu istotne jest tworzenie wiedzy w zgodzie z zasadami narracji, co oznacza zwrot ku narracjom literackim. Jerome Bruner postuluje, by rozszerzyć patrzenie na edukację o aspekt narracyjny, dzięki czemu wychowanek będzie rozumiał zarówno świat naukowy, jak i potoczny, a także samego siebie i własne potrzeby ${ }^{45}$. W praktyce pedagogicznej narracje mogą być wykorzystywane na kilka sposobów. Po pierwsze, wychowawca korzysta $z$ istniejących materiałów literackich, by zobrazować wychowankowi różne wartości, zachowania i sposoby funkcjonowania w świecie. Po drugie, pracuje $z$ wychowankiem nad tworzonymi przez niego narracjami, by poznać jego potrzeby, sposoby funkcjonowania, a tym samym zindywidualizować proces wychowawczy. Kształtowanie siebie i swojego życia poprzez mówienie o sobie pozwala uporządkować różne życiowe kwestie i nabrać dystansu do samego życia. Oba sposoby realizowania narracji przez pedagogiczną praktykę zbliżone są do tych, które wykorzystywane są w psychologii (terapii). Po trzecie, narracja kształtowana jest przez uczestniczenie w szeroko pojmowanym wychowaniu, które następuje w toku całego ludzkiego życia (od urodzenia do śmierci). Narracja jest warunkowana przez wszystkie znaczące dla danej jednostki osoby, zdarzenia, dzieła sztuki etc., z którymi ona obcuje. W artykule pokazany został przede wszystkim pierwszy sposób wykorzystania narracji w pedagogice.

${ }^{45}$ M. Reut, Narracja i tożsamość. Pytanie o „ja” jako problem etyczny i pedagogiczny, Wydawnictwo Naukowe Dolnośląskiej Szkoły Wyższej, Wrocław 2010, s. 127-131. 


\section{Bibliografia}

Bal M., Narratologia. Wprowadzenie do teorii narracji, Eidos Wydawnictwo Uniwersytetu Jagiellońskiego, Kraków 2012.

Ciszewski S., Krakowiacy. Monografia etnograficzna, t. 1, Nakładem Autora, Kraków 1894.

Doroszewski W. (red.), Słownik języka polskiego, https://sjp.pwn.pl/ [dostęp: 4.01.2019].

Dunaj B. (red.), Wielki słownik języka polskiego, Buchmann, Warszawa 2009.

Eliade M., Sacrum i profanum. O istocie religijności, przeł. R. Reszke, Wydawnictwo KR, Warszawa 1999.

Głowiński M. i in. (red.), Słownik terminów literackich, Ossolineum, Wrocław 1989.

Grafenauer N., Skrivnosti, Založba Borec, Ljubljana 1990.

Grimal P., Słownik mitologii greckiej i rzymskiej, Zakład Narodowy im. Ossolińskich, Wrocław 2008.

Jazowski A., Opowieści ludu spiskiego, Ludowa Spółdzielnia Wydawnicza, Warszawa 1967.

Jurkowska M., Stankiewicz D.O., Wojtowicz M. (red.), Dziecko jako podmiot poznania, Uniwersytet w Białymstoku, Białystok 2016.

Kowalski P., Woda żywa. Opowieść o wodzie, zdrowiu, higienie i dietetyce, Towarzystwo Przyjaciół Ossolineum, Wrocław 2002.

Krawczyk A., Bohatera literackiego droga przez życie. Na podstawie utworu „Pedenjped” Nika Grafenauera, [w:] M. Jurkowska, D.O. Stankiewicz, M. Wojtowicz (red.), Dziecko jako podmiot poznania, Uniwersytet w Białymstoku, Białystok 2016.

Lorentz F., Teksty pomorskie, Polska Akademia Umiejętności, 1924.

Nowak P., Pragmalingwistyka a narracja: tożsamość, kooperacja, sprzeczność, [w:] J. Wasilewski (red.), Narracje w życiu. O grupie i jednostce, Instytut Dziennikarstwa Uniwersytetu Warszawskiego, Warszawa 2016.

Oxford - Wielka Historia Świata. Cywilizacje Europy. Anglia - Słowianie. Cywilizacje Australii i Oceanii. Papuasi, t. 13, Polskie Media Amer.Com, Poznań 2006.

Reut M., Narracja i tożsamość. Pytanie o „ja” jako problem etyczny i pedagogiczny, Wydawnictwo Naukowe Dolnośląskiej Szkoły Wyższej, Wrocław 2010.

Savanevičienë A. (Żygiel), Współczesne zwyczaje i obrzędy pogrzebowe na Wileńszczyźnie, http://naszczas2002.tripod.com/048/czas.html [dostęp: 4.01.2019].

Skasida I., Mladinska književnost med literarno vedo in književno didaktiko, Založba Obzorja, Maribor 1994.

Wasilewska K., „Ja” w autonarracji o pierwszym macierzyństwie, [w:] J. Wasilewski (red.), Narracje w życiu. O grupie i jednostce, Instytut Dziennikarstwa Uniwersytetu Warszawskiego, Warszawa 2016. 
Wasilewski J. (red.), Narracje w życiu. O grupie i jednostce, Instytut Dziennikarstwa Uniwersytetu Warszawskiego, Warszawa 2016.

\section{Skrivnosti by Niko Grafenauer as the revealing of secrets}

Abstract: The article presents an analysis of Skrivnosti (Secrets) - a collection of poems by Niko Grafenauer. References are made to general concepts regarding narration which constitute the basis for interpretation of the author's poems. Skrivnosti are a collection of secrets which may be unveiled by readers themselves, but which also aid tutors working with young people. The aim of the text is to familiarize Polish readers with the works of the Slovenian poet, to use the narrative aspect to analyse poetic work, and to demonstrate how poetry may be used in pedagogical practice.

Keywords: Skrivnosti, Niko Grafenauer, Slovenian poetry, youth literature, narration

\footnotetext{
About the author: Agnieszka Krawczyk - MA in Slavic Philology and Pedagogy; Assistant Professor at The Department of Educational Studies at the Faculty of Educational Sciences, University of Lodz. Her Research interests include multicultural pedagogy, culture, Jewish culture, narratology, methodology, qualitative research, literature, children's and juvenile literature.
} 
Natalia Piórczyńska* (iD) https://orcid.org/0000-0003-0296-1326

Akademia Humanistyczno Ekonomiczna w Łodzi

https://doi.org/10.25312/2083-2923.17/2020_11np

\section{Recenzja książki Lustereczko, powiedz przecie Simona Blackburna}

Wydawnictwo Uniwersytetu Łódzkiego, Łódź 2018, 350 stron

Polskojęzyczne tłumaczenie książki Simona Blackburna Mirror, Mirror: The Uses and Abuses of Self-Love ukazało się kilka miesięcy temu nakładem Wydawnictwa Uniwersytetu Łódzkiego w ramach serii filozoficznej „Kim Jest Człowiek?”. Ambicją wydawcy jest popularyzowanie filozofii i uwrażliwianie odbiorców na problemy natury etyczno-filozoficznej. Lustereczko, powiedz przecie - bo tak brzmi polski tytuł książki - podejmuje temat współczesnego narcyzmu.

Narcyz, słysząc głos nimfy Echo, myśli, że są to słowa innej osoby. W rzeczywistości słyszy własne, które Echo tylko powtarza. Blackburn, odwołując się do mitu o Narcyzie, mówi, że nasza tożsamość tworzy się przez to, jak jesteśmy postrzegani przez innych. A może raczej przez to, jak myślimy, że oni nas postrzegają, ponieważ to, co widzimy, przeglądając się w ich spojrzeniu, często jest projekcją naszych przekonań.

Autor Mirror, mirror... przywołuje hasło reklamowe L’Oreal: „Ponieważ jesteś tego warta”, i udowadnia, że ten komunikat niesie nieco inną treść: „Ponieważ nie jesteś tego warta, ale jeśli kupisz nasz produkt, możesz być”. Koncern tworzy na ten temat inną narrację. Ilon Specht zaproponowała to hasło na przekór dominującemu

\footnotetext{
“ Natalia Piórczyńska - dr nauk humanistycznych w zakresie literaturoznawstwa, piarowiec, wykładowczyni przedmiotów związanych z komunikacją w nowych mediach. Absolwentka studiów podyplomowych na kierunku Ilustracja i komiks z elementami preprodukcji gier i filmów. Założyła pierwszą w Polsce wieloautorską blogosferę popularnonaukową zrzeszającą autorów z różnych dyscyplin naukowych, która funkcjonuje przy Wydawnictwie Uniwersytetu Łódzkiego. Pracuje w Akademii Humanistyczno-Ekonomicznej w Łodzi, gdzie od kilku lat zajmuje się tworzeniem programów nauczania na kierunku filologia polska na specjalnościach związanych z nowoczesnymi formami komunikacji. Pełni obowiązki redaktor naczelnej czasopisma „Literaturoznawstwo”.
} 
40 lat temu w reklamie sposobowi mówienia do kobiet, który miał polegać na tym, że one starały się być atrakcyjne dla mężczyzn, a oni - jeśli stosowały reklamowany produkt - mieli tę atrakcyjność docenić i potwierdzić.

Blackburn pisze, że modelki w kampaniach L'Oreal są zimne i zarozumiałe. Wiedzą, że są doskonałe i patrzą na nas z góry: „często z ich postaci zdaje się przebijać egoizm, arogancja czy pogarda. Obdarzają nas tym rodzajem uśmiechu, który równie dobrze mógłby być szyderczy. Wydymają wargi i stroją fochy. Ich próżność i obojętność wiąże się z tym, że są ponad nami, a zapewne także wiedzą, że mogą dowolnie wywoływać nasz podziw i uwielbienie. Nie przejmują się tym, co o nich myślimy”.

Istotnie, kobiety z reklam L'Oreal są zazwyczaj niedostępne, zarozumiałe i oczekują podziwu. Zanim marketingowcy skonstruują komunikat reklamowy, stworzą personę klienta marki. Oznacza to, że jeżeli reklama L’Oreal skłoni jej odbiorczynie do zakupu produktu francuskiego koncernu, to znaczy, że najpewniej chcą chociaż w jakimś stopniu być jak kobieta, która mówi: „Ponieważ jesteś tego warta”. Blackburn ma rację: to, co usłyszą, będzie echem głosów w ich głowach, które mówią najwyraźniej, że adresatki reklamy aspirują do czegoś, czego obietnicę dostrzegły w reklamie. W dalszej części tego wywodu Blackburn stwierdza, że skuteczność przekazu reklamowego świadczy o tym, że ich odbiorczynie to - niestety, inaczej nie da się tego ująć - płytkie intelektualnie nieudacznice:

„Niestety, ludzie nie zakochują się i nie zamierają z podziwu, kiedy kupują nową szminkę. Mają swoje życia, które muszą prowadzić. Magia nie działa, a klientka musi przegrać. Ale w jej wyobraźni rozwiązanie może polegać na tym, by spróbować jeszcze raz! Mocniej! Być może zadziała kolejny krem do twarzy, szminka, kolor włosów albo samoopalacz. Jeśli pielęgnacja jaźni nie zadziała od razu, spróbuj jeszcze raz. Oddaj się temu całkowicie i nie zwracaj uwagi na koszty. W ten oto sposób otwiera się przed klientką smutny, nieskończony szereg niespełnionych nadziei, niezadowolenia i rozczarowania, ale jest on zarazem dogodnym, nieskończonym szeregiem zysku dla producenta. Aż chciałoby się krzyknąć, że oszukiwana klientka może i powinna pomyśleć, że jest warta więcej niż to, czego staniem się ryzykuje, czyli wymizerowaną łowczynią złudzeń, ale takie ostrzeżenie nie ma szans w rywalizacji z głosem iluzji”. Ten rozdział ma dwoje bohaterów: Narcyza i tę niezdolną do obiektywnej samooceny i niemądrą kobietę - „wietrzną istotę”. W jednym, ale to w jednym zdaniu pojawia się zdawkowy komentarz, że tym destruktywnym dążeniom, które funkcjonują w naszej narcystycznej kulturze, podlegają też mężczyźni, realni mężczyźni, a nie postaci mitologiczne. W jednym zdaniu na przeszło 30 stron. Może Blackburn jest mędrcem w wieży z kości słoniowej, a może mizoginem, ale bardzo jednostronnie ocenia kobiety. Pogoń za pięknem, która może się wymknąć spod kontroli, nie prowadzi dziś do drogerii, tylko do gabinetu medycyny estetycznej. Nie trzeba wydymać warg, wystarczy kwas hialuronowy, więc kiedy tabloidy donoszą, że celebrytka pokazuje się bez makijażu i zdejmuje maskę, to pod nią jest kolejna - $\mathrm{z}$ hialuronu. W dalszym ciągu jednak nie wiem, czy to zjawisko ma coś wspólnego z karykaturą opisaną przez Black- 
burna. Obawiam się jednak, że mamy tu do czynienia z jego konstruktem myślowym, który ma patriarchalne podłoże.

Blackburn jest zdecydowanie bardziej przekonujący, kiedy pisze o narcyzmie rządzących i egoizmie w sferze ekonomicznej, który wyraża się w haśle, że „chciwość jest dobra”. Autor opisuje nierówności i podaje dane: „1\% Amerykanów posiada 30\% osobistego majątku całego kraju; pieniądze trzech najbogatszych ludzi w Ameryce mogłyby spłacić cały deficyt Stanów Zjednoczonych”, a w latach 2009-2011 „przychody najbogatszego 1\% wzrosły o $11,2 \%$, podczas gdy dochód 99\% ludności zmalał o 0,4\%”. Przytaczam statystyki, które Blackburn czyni tu punktem wyjścia, ale właśnie te rozdziały książki są według mnie najistotniejsze. Pokazują, jak brak wyobraźni pozwalającej na postawienie się w sytuacji innego człowieka albo jedynie deklaratywny szacunek dla jego podmiotowości przyczyniają się do erozji społeczeństwa obywatelskiego. W naszej kulturze, bo nierówności między Zachodem a krajami rozwijającymi się wychodzą daleko poza tę skalę. I tak jak bogaci na Zachodzie „odgradzają się od reszty, starając się nie dostrzegać istniejącego dookoła zła”, tak my raczej nie mamy codziennie w pamięci, że na świecie głoduje 821 milionów ludzi.

Czy Blackburn wskazuje rozwiązanie tych dylematów? „Nic nie jest takie proste” - pisze, ale daje też sugestię, że ostatecznie wszystko zależy od nas: naszej świadomości siebie i otaczającego świata oraz umiejętności stawiania sobie możliwych do realizacji celów.

Właśnie te fragmenty, w których Blackburn mówi o etyce, są najbardziej wartościowe, przy czym często najciekawsze intelektualnie okazują się myśli wtrącane $\mathrm{w}$ formie dygresji. To istotne, bo są w tej książce całe fragmenty rozdziałów, w których Blackburn streszcza filozofię, kiedy mógłby przedstawić swój tok myślenia bez tych odwołań, zwłaszcza że one same często nie wnoszą nowych znaczeń. Czytając o człowieku szlachetnym u Arystotelesa w sąsiedztwie utyskiwań na współczesne zepsucie obyczajów, czytelnik zaczyna się irytować, tym bardziej że autor dokonuje tutaj odkryć na miarę ogólnego kursu filozofii dla studentów pierwszego roku. Tymczasem Blackburn jest o wiele bardziej przekonujący, kiedy mówi swoim językiem i używa własnych konstrukcji myślowych. Autor często coś wtrąca i dopowiada, popada w dygresje, przy czym potrafi w kilku rzuconych niezobowiązująco zdaniach dotknąć istoty, jak na przykład w miejscu, w którym pisze o tym, że nowy ateizm jest zwyczajnie obok problemu: „Błędem jest [...] rozpatrywanie umysłowości religijnej przede wszystkim w kategoriach przekonań (belief). Podobnie błędne jest zakładanie, że ów element dotyczy w pierwszej kolejności istnienia czegos'”. 


\section{Recenzja książki Anny Konarzewskiej Być (nie)zwykłym wychowawcą. Scenariusze lekcji wychowawczych dla uczniów klas starszych szkoły podstawowej oraz szkół ponadpodstawowych}

Warszawska Firma Wydawnicza, Warszawa 2019, 217 stron

Anna Konarzewska, autorka książki Być (nie)zwyklym wychowawca, podjęła się niełatwego zadania. Jest tutorem zarówno dla doświadczonych nauczycieli, jak też dla nowicjuszy, którzy próbują i mierzą swe siły w pracy wychowawcy. Ułatwia, zachęca, przedstawia i promuje w przemyślany sposób, jak edukować młodych ludzi, prowadząc wyjątkową godzinę wychowawczą.

Książka liczy 217 stron. Uwagę zwraca estetyczna szata graficzna, już ilustracja na okładce intryguje, uwalniając naszą interpretację co do relacji uczeń-nauczyciel. Zachęca do zajrzenia do środka. Zaskakuje rzadko dziś spotykanym papierem kredowym, załączonymi barwnymi fotografiami do scenariuszy, których nie znajdziemy w żadnej tego typu publikacji, oraz kolorowymi nowatorskimi ilustracjami autorstwa: Sylwii Oszczyk, Mateusza Łyska, Magdaleny Budy i Vitii Hoffmann.

Wytrawny czytelnik, jakim jest zapewne doświadczony nauczyciel, od razu przystąpi do wykorzystania scenariuszy zajęć w swojej pracy wychowawczej, a nowicjusz doceni bardzo dokładne omówienie, przygotowanie oraz każdorazowe wprowadzenie $\mathrm{w}$ temat poruszanego problemu.

Tytuł książki oddaje dobrze formalną jej zawartość. Autorka zainspirowana efektem Pigmaliona i Golema oraz twórczością i działalnością Janusza Korczaka tworzy punkt wyjścia do podmiotowego traktowania uczniów i osiąga swój cel. Czytelnik już

* Jasmina Al-Douri - mgr Katedry Edukacji Artystycznej Wydziału Nauk o Wychowaniu Uniwersytetu Łódzkiego, doktorantka Instytutu Pedagogiki, Wydziału Nauk Społecznych Uniwersytetu Gdańskiego. 
na wstępie poznaje krok po kroku wszystkie etapy zdobycia trudnego szczytu, jakim jest miano (nie)zwykłego wychowawcy.

Publikacja ma charakter poradnika. Podzielona jest na pięć części, z których każda tworzy odrębną całość. Artykuły wprowadzają w świat psychologii i edukacji. Autorka skłania do refleksji i zachęca do przemyśleń, na co współcześni pedagodzy winni zwracać uwagę.

Integracja młodych ludzi, kształcenie kompetencji miękkich czy problemy współczesnego świata to obszary, które są poruszane i bardzo dokładnie opisane do wykorzystania w pracy podczas lekcji wychowawczych. Różnorodność tematyczna to atut tej publikacji - poradnika.

W pierwszym rozdziale, który jest wstępem, autorka uchyla drzwi i kreśli współczesną sylwetkę nauczyciela wychowawcy w kontekście i na podbudowie filozofii i myśli Janusza Korczaka. W kolejnym intryguje pytaniami o inny rodzaj szacunku oraz o sposób uzyskania autorytetu czy motywacji wśród uczniów. Dalej na układ treści składają się dokładnie przemyślane różnorodne obszary zagadnień, uporządkowane tak, by wprowadzić w meandry problematyki współczesnego świata.

Scenariusze zajęć tworzą kompendium wiedzy nauczyciela wychowawcy. Są bogate w metody aktywizujące uczniów oraz zawierają bardzo dokładnie przedstawione środki dydaktyczne, które podnoszą i podkręcają motywację młodych ludzi do pracy podczas zajęć. Przebieg lekcji jest tak przedstawiony, że nikt nie będzie miał problemu z realizacją określonego tematu. Autorka zadbała o każdy szczegół oraz o wnioski końcowe. Nauczyciel nie tylko na poszczególnym poziomie awansu zawodowego, ale także nowicjusz mają przed sobą bogactwo możliwości do wykorzystania w treningu umiejętności społecznych, wszystko zawarte w jednej zwartej publikacji.

Można mieć zastrzeżenia co do proponowanego przez autorkę czasu prowadzenia określonych tematów. Rzeczywistość szkolna rzadko daje możliwość realizacji dwugodzinnego bloku zajęć wychowawczych, czyli 2 x 45 minut. Godzina wychowawcza jest czasami wykorzystywana przez nauczycieli jako dodatkowy czas poświęcony swojemu przedmiotowi w związku z realizacją podstawy programowej, chociaż jest to niezgodne $\mathrm{z}$ prawem.

Na szczególną uwagę zasługują scenariusze dla rodziców, „by odważyli się mówić”, oraz kolorowe karty do wykorzystania przez czytelnika. Szkoda tylko, że nie można ich użyć bezpośrednio w pracy.

Publikacja powinna zwrócić uwagę i zainteresować pedagogów, psychologów i terapeutów. Sądzę, że sięgną po nią jednostki twórcze, kreatywnie działające w nowoczesnej szkole. Może ona stanowić główne i niezastąpione kompendium wiedzy oraz być inspiracją dla wielu osób działających w pokrewnych dziedzinach.

To pierwsza tego rodzaju publikacja przeznaczona dla praktyków, która swoją zawartością nie tylko zaskoczy, ale i w efekcie sprosta oczekiwaniom młodzieży, jak również zainspiruje do nowatorskich działań w przestrzeni szkolnej nie tylko nauczycieli i wychowawców. Godna polecenia. 


\author{
Katarzyna Ewa Kuchnicka* \\ Akademia Humanistyczno-Ekonomiczna w Łodzi
}

https://doi.org/10.25312/2083-2923.17/2020_13kek

\title{
Metoda sióstr Agazzi w wychowaniu przedszkolnym
}

\begin{abstract}
Streszczenie: Włochy przez bardzo długi okres nie interesowały się edukacją dzieci. Pierwsze centrum opieki nad nimi zostało założone w 1828 roku w Cremonie przez ks. Ferrante Aportiego. W latach 1895-1917 kolejną instytucję otworzyły siostry Agazzi w Nave, niewielkiej prowincji Bresci. Dzieci, którymi się zajmowały, pochodziły z bardzo trudnego środowiska. Założycielki powtarzały młodym nauczycielkom, że ich zadanie jest delikatne i często angażujące wszystkie osobiste zasoby, wymagając przy tym fizycznej energii, niezłomnych postaw i silnego charakteru. Według Agazzi, nauczycielka powinna być przygotowana do spełniana z pokorą zadań, bez okazywania w obecności dzieci oznak niechęci. Agazzi w pracy z dziećmi wykorzystywały proste i powszechnie używane materiały, dziecko mogło tworzyć od zera i robić coś samodzielnie własnymi rękoma i wykorzystując wyobraźnię. Czynności, które dziś potocznie nazywamy robótkami ręcznymi, miały wielką wartość edukacyjną. Towarzyszyły dziecku w odkrywaniu świata, kształtując umiejętność budowania i coraz bardziej świadomego tworzenia. Zabawa wszystkim tym, co naturalne, oferowała dziecku możliwość pełnego wyrażania swojej kreatywności. Również porządkowanie, mycie rąk - były idealnym sposobem na zabawę i naukę. W taki sposób powstała „rupieciarnia”. Metoda ta okazała się wielkim sukcesem i zaczęła być stosowana w wielu przedszkolach na terenie Włoch.
\end{abstract}

Słowa kluczowe: aktywność, przedszkole, metoda, edukacja sensoryczna, edukacja estetyczna, muzeum dydaktyczne, ogrodnictwo, nauka języków

* Katarzyna Ewa Kuchnicka - absolwentka Akademii Humanistyczno-Ekonomicznej w Łodzi, Wydział Humanistyczny, kierunek pedagogika. Zainteresowania: edukacja dzieci w wieku przedszkolnym i potrzeba rzetelnego profesjonalizmu w tym sektorze. 
Nic nie jest bezużyteczne, jeśli wiadomo, jak to wykorzystać.

Rosa Agazzi

Zainteresowanie edukacją dzieci w wieku przedszkolnym i przekonanie o potrzebie rzetelnego profesjonalizmu w tym sektorze były dla mnie głównymi powodami, dla których cztery lata temu entuzjastycznie podjęłam studia. W miarę upływu czasu i zdobywania coraz większej wiedzy moja uwaga skupiła się na bardziej ukierunkowanym polu: edukacja szkolna dzieci w wieku od trzech do sześciu lat, czyli w okresie, kiedy to naprawdę zasługiwały na ogromną uwagę, i orientacje wychowawcze w drugiej połowie XIX wieku.

Pamiętam, że moje pierwsze poszukiwania skoncentrowały się jedynie na paru bibliotekach na terytorium Bresci, ze szczególnym odniesieniem się do autorów, którzy żyli i tworzyli myśl pedagogiczną końca XIX wieku. Jednakże to właśnie życie sióstr Agazzi, ich dzieła i pasja do pracy z dziećmi sprawiły, że inni wielcy pedagodzy zeszli na drugi plan. Prostota i bezpośredniość dzieł sióstr Agazzi oraz wielkość, a jednocześnie nowoczesność ich ideałów były punktami, które zdeterminowały mój ostateczny wybór.

Moja praca nabrała kształtu przede wszystkim dzięki współpracy z Centrum Studiów Pedagogicznych, Instytut Pasquali-Agazzi w Mompiano (Brescia, Włochy), z którym udało mi się nawiązać kontakty. Ciągłe wizyty w bogatej bibliotece do dyspozycji studentów, nauczycieli oraz uczonych, spotkania z Panią Elisabettą - pracownicą instytutu, a także odwiedziny w przedszkolu, gdzie wykorzystuje się metodę Agazzi, pozwoliły mi na zebranie materiałów dydaktycznych niezbędnych do napisania mojej pracy. Miałam też możliwość uczestniczenia w jednym ze spotkań organizowanych przez instytut. Spotkanie to wzmocniło we mnie jeszcze bardziej ciekawość poznania metody Agazzi oraz rzeczywistości społecznej tamtych lat, a także chęć odkrycia zasad edukacyjnych i pogłębienia znaczenia i roli muzeum dydaktycznego w doświadczeniu edukacyjnym szkoły w Mompiano (Brescia).

\section{Życie i myśli sióstr Agazzi}

Siostry Agazzi swoją działalność rozpoczęły w roku 1882, był to okres wielkich strajków. Protesty społeczne wzmagały się z powodu zarówno desperacji ich uczestnikó, jak i surowej reakcji policji. Chłopi, żyli w bardzo nędznych warunkach, co przyczyniało się do wielu chorób, wysokiej śmiertelności i oczywiście wykorzystywania dzieci do prac fizycznych. Rzeczywistość ta była dobrze znana Agazzi, chociażby z Volongo, gdzie warunki życia nie były lepsze. Rosa, wspominając swoje dzieciństwo, pisze, że wieśniak w dni robocze, od świtu do zachodu słońca zarabiał osiemdziesiąt centów. Wystarczało to na drobne wydatki, takie jak: olej, ocet, sól. Chleb, jako luksusowa 
żywność dla zamożnych, nigdy nie pojawiał się na stole ubogich ${ }^{1}$. W prowincji Cremona najwyższy kapłan i wujek Rosy i Karoliny Agazzi, ksiądz Francesco Zapparoli, na wszelkie sposoby starał się pomóc mieszkańcom. Jego działalność pomocowa wzbudziła u sióstr pierwsze zainteresowanie edukacją. Dwie nauczycielki zmuszone były eksperymentować z trudnymi warunkami społecznymi panującymi w tych latach. Zaczęły uczyć w Bresci, która w porównaniu z innymi obszarami Włoch była w znacznie lepszej sytuacji. Miasto to dysponowało środkami na rozbudowę przedszkoli również na przedmieściach. W tym okresie powstało również czasopismo „La vendetta lombarda” (Zemsta lombarda) oraz na pedagogicznej niwie pojawiły się takie osobowości, jak Carlo Tegon i Pietro Pasquali².

Agazzi swoją karierę edukacyjną zaczęły w Nave, niewielkiej prowincji Bresci, gdzie w roku 1889, Karolina uczyła w przedszkolu, które znajdowało się w stodole i mieściło 180 dzieci. Później liczba ta została zmniejszona do 125. Rosa pracowała na piętrze, gdzie jako nauczycielka w szkole podstawowej miała pod swoją opieką 73 uczniów między 6. a 12. rokiem życia ${ }^{3}$.

Dzieci, którymi siostry się zajmowały, pochodziły z bardzo trudnego środowiska, ich matki często zaangażowane były w ciężkie prace w fabrykach lub pracowały na wsi w celu poprawy złej sytuacji ekonomicznej rodziny. Rosa Agazzi była zaszokowana niewłaściwym użyciem języka, niskim poziomem higieny intymnej i licznymi problemami zdrowotnymi, które niestety dotykały dzieci: „odmrożenia, strupy, pęk-

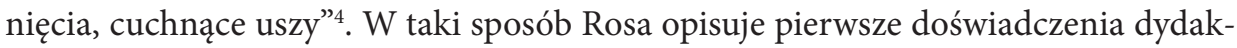
tyczne: „rzadkie ślady czystości, żadna zasada ładu i szacunku: dialekt barbarzyński, przedpotopowe ławki w pomieszczeniu, w którym niemożliwe jest swobodne oddychanie" " Warunki higieniczne były niczym innym, jak tylko aspektem głębszego problemu: zupełnego zaniedbania, w którym dorastały dzieci.

Wracając do funkcjonowania placówki, którą prowadziły siostry, przede wszystkim należy podkreślić, jak poważnym problemem w jej zarządzaniu był brak odpowiedniego zaplecza lokalowego, a miejsca, które służyły do nauki, nie spełniały fizycznych i psychicznych potrzeb dzieci. Przedszkole, w którym pracowała Rosa, prezentowało się jako skromne, wilgotne miejsce na parterze, dawna siedziba gminy, wysokie okna z zakurzonymi czerwonymi cegłami ${ }^{6}$. W Mompiano - Brescia, gdzie w 1895 roku uczyła Karolina Agazzi, przedszkole powstało w zakrystii kościoła, którą udostępniono na prośbę gminy. Ale nikt nie przypuszczał, że dzieci, częściowo

${ }_{1}^{1}$ R. Agazzi, Nella cultura pedagogica italiana e nella realtà educativa della scuola materna, Istituto Pasquali-Agazzi, Brescia 1995, s. 60.

2 Tamże, s. 61.

3 Aldo Agazzi, S.S. Michietti, L’educazione dell'infanzia nella scuola materna, La Scuola, Brescia 1991, s. 16.

${ }^{4}$ G. Ugonini, Mompiano, La Scuola, Brescia 1942, s. 62 [cytaty z języka włoskiego w tłumaczeniu autorki artykułu].

${ }^{5}$ R. Agazzi, Guida per la educazione dell'infanzia, La Scuola, Brescia 1950, s. 60.

${ }^{6}$ G. Ugonini, dz. cyt., s. 63. 
umieszczone w sali i częściowo w małym magazynku, będą miały ogromne trudności w poruszaniu się. Natomiast mała kuchnia i ubikacja na końcu korytarza nie spełniały wymogów higienicznych.

Rosa, zjednoczona myślą z Piero Pasqualim, swym nauczycielem i dyrektorem dydaktycznym, a także ważnym współpracownikiem, dokonała realistycznego przeglądu warunków panujących we włoskich przedszkolach pod koniec XIX wieku. Według niej, nauczyciele to kobiety wszystkich klas i kultur, z licencją lub bez niej, posiadające mniejsze lub większe zdolności nauczycielskie. Jeśli zaś chodzi o pomieszczenia, to niewiele $z$ nich spełniało podstawowe warunki do nauki. Nie da się ukryć, że z tak ogromnie trudną rzeczywistością musiały zmagać się siostry Agazzi. Mowa tutaj o dzieciach biednych i zaniedbanych, pochodzących z rodzin wiejskich, których członkowie bardzo często byli analfabetami szukającymi lepszego życia. Nie pomagał im również fakt, że infrastruktura szkolna rozpadała się, a kadra pedagogiczna również pozostawiała wiele do życzenia. O tym, jak trudne zadanie stało przed dwoma młodymi nauczycielkami, świadczy list Rosy do burmistrza miasteczka Nave w 1889 roku:

W pierwszych dwóch miesiącach wydawało mi się, że jestem w szpitalu psychiatrycznym, aby nie powiedzieć w piekle. Rozbieżność dziewczynek w latach od 6 do 12, ich żywotność nieco dzika, powietrze było tak ciężkie, że trudno było oddychać, a spowodowane było to w dużej mierze przez całkowity brak czystości uczniów. Niedobór papieru, długopisów, i wielu innych rzeczy wprowadziły do mojej szkoły taki bałagan, że jeśli mógłby Pan wejść do środka, wybaczyłby mi Pan, że czasem siedzę przy stole z rękami na twarzy, żeby ukryć moje łzy. Wielokrotnie zmuszano mnie do użycia kary; ale jako przeciwniczka, niestety, za każdym razem musiałam połykać gorzkie pigułki od rodziców! Szkoła rozpoczyna się o 9.00 i większość uczennic przychodzi na 10.00; niektóre pojawiały się tylko jeden dzień i pozostawały w domu cały tydzień, potem wracały bez zeszytu, bez długopisu i podczas odpoczynku przeszkadzały innym dzieciom. Zaczęłam się poświęcać, pozostając w szkole pół godziny dłużej, zatrzymując tym samym te dzieci, które były niegrzeczne: co się dzieje? Matki zaczęły nachodzić mnie w szkole i podczas całego roku wielokrotnie zdarzyło mi się ulec obelgom tych ignoranckich ludzi przed całą szkołą. Potem ograniczyłam się do stawiania w kącie niegrzecznych dzieci, ale oto pojawia się mój przełożony i odsyła je z powrotem do ławki, w ten sposób cierpi mój biedny autorytet... oh, niech Pan mi uwierzy, że po tych faktach opadają ręce i moja gorliwość grozi pójściem w dym ${ }^{7}$.

Te kilka zdań wyjaśnia nam to, jakimi ideami w kwestii wychowania dzieci kierowała się Rosa, ale także ukazuje jej odważny i niepowtarzalny charakter. Taka rzeczywistość zniechęciłaby każdego, ale nie ją. Poczuła się ona jeszcze bardziej zmotywowana do poprawy warunków szkolnych, a zatem także przyszłości dzieci. Narodziny

7 R. Mazzetti, P. Pasquali, Le Agazzi e la riforma del frobelismo in Italia, Armando, Roma 1967, s. 64 . 
metody wychowawczej mogą być postrzegane jako próba poprawy losu tak niezwykle trudnego dla ludności Włoch.

\section{Trudna komunikacja między Marią Montessori i Rosą Agazzi}

W roku 1909 i potem jeszcze w 1913 i 1926 Rosa Agazzi prawdopodobnie została poinformowana przez innych, a później miała również okazję wielokrotnie przeczytać o tym, że w jednym z dzieł Marii Montessori pt. Il Metodo della Pedagogia scentifica applicata all'Educazione Infantile nelle Case dei bambini (Metoda pedagogiki naukowej stosowanej w edukacji dziecięcej w domach dziecka) zostały zastosowane, jako istotna część metody, „ćwiczenia praktyczne”, których autorem była Rosa. Niestety, ani Pasquali, ani siostry Agazzi nie złożyli wniosku w tej sprawie. Zrobili to dopiero wtedy, gdy włoski pedagog i filozof Lombaro Radice zainteresował się metodą Agazzi, opisując ją w czasopiśmie „Leducazione Nazionale” (Edukacja narodowa). W roku 1926 opublikował on bardzo długi artykuł napisany przez Rosę Agazzi o tytule I metodi italiani. Gli asili ed il metodo Agazzi e Pasquali iniziatosi nel 1898 (Włoskie metody stosowane w przedszkolu i zapoczątkowane przez Agazzi i Pasqaulego w roku 1898), w którym to Rosa w sposób bardzo skrupulatny deklaruje, że to właśnie ona jest twórczynią nowej włoskiej szkoły dla dzieci. Nazwisko Montessori zostało zacytowane więcej niż jeden raz, gdzie Agazzi oskarżyła ją o zawłaszczenie jej idei. Usilnie starała się przypomnieć wiele przypadków, w których ćwiczenia Agazzi były błędnie przypisywane Montessori, która z kolei nigdy nie zadała sobie trudu zacytowania Agazzi. Warto przypomnieć w tym miejscu publikację Grazii Honegger Fresco. Kurator ta przedstawia kompletną transkrypcję listu napisanego przez Montessori około 1928 roku. Dokument ten jest ważny z dwóch powodów: po pierwsze, jest on napisany w trzeciej osobie przez samą Montessori i po drugie, wydaje się, że nie został on nigdy opublikowany. Prawdopodobnie miał się pojawić w czasopiśmie prowadzonym przez Montessori, ale nigdy do tego nie doszło z przyczyn do tej pory nam nieznanych. W treści listu Montessori deklaruje, że absolutnie nie odebrała siostrom Agazzi ich pomysłu na ćwiczenia praktyczne, definiując Rosę jako nauczycielkę o bardzo ograniczonej i prowincjonalnej doktrynie, która nie ma pojęcia o tym, co jest naprawdę ważne w wychowaniu dzieci, w związku z tym nie ma ona do zaoferowania żadnego pomysłu, który zasługiwałby na jakiekolwiek zainteresowanie. Oto końcowa część listu: „Montessori była wojowniczką, z ogromnym wysiłkiem przełamując lody uprzedzeń, które utrudniały awans kobiet na uniwersytetach, szczególnie w dziedzinie medycyny. Ona aspirowała do czegoś innego [...] bronić spraw naukowych, których rozwiązanie było w szkole, a nie w realizacji z nauczycielami czy plagiatu wobec nauczycieli"".

${ }^{8}$ G. Honegger Fresco, Montessori: perché no? Una pedagogia per la crescita. Che cosa ne è oggi della proposta pedagogica di Maria Montessori nell'Italia e nel Mondo?, Angeli, Milano 2000, s. 80. 
Idea życiowych ćwiczeń praktycznych, według wyjaśnień udzielonych przez lekarkę, pojawiła się u niej po kontakcie z zakonnicami, misjonarkami z Rzymu. „Jest nieprawdą, że skopiowałam metodę życiowych ćwiczeń praktycznych od sióstr Agazzi i użyłam w moich szkołach [...]. Miałam wrażenie, że w ich przypadku ćwiczenia te mogły być zainspirowane sukcesem zakonnic Misjonarek w szkole przy ulicy Giusti, która powstała jako schronisko dla sierot pokrzywdzonych podczas katastrofalnego trzęsienia ziemi w Mesynie w grudniu 1908 roku"9.

Pomijając fakt, kto naprawdę był inicjatorem tej metody, warto pamiętać, że ma ona inną wartość w myśleniu dwóch pedagogów. Dla Agazzi opierała się ona na spontaniczności i osobistym doświadczeniu z dziećmi, które były przygotowywane do życia w społeczeństwie, radzenia sobie w różnych sytuacjach, słuchania muzyki, śpiewu i poznawania nowych rzeczy. Dziecko było uważane za wielkość w swoich fizycznych, intelektualnych i moralnych elementach. Agazzi uwzględniały katolicką metrykę i rolę matki w kulturze włoskiej edukacji. Chciały one przekształcić dotąd istniejące przedszkola i uczynić je bardziej przyjazne dzieciom. Przedszkola miały za zadanie wzmocnić złożoność doświadczeń życiowych dzieci. Małe jednostki powinny wzrastać w środowisku, które stymulowało ich kreatywność przez owocny dialog z dorosłym. Według Agazzi, nic nie było lepszego niż rodzinna atmosfera, która dzięki swoim cechom emocjonalnym mogła sprawić, że edukacja stawała się naprawdę istotna. Dziecko i jego działania były umieszczone w centrum uwagi, a materiały edukacyjne charakteryzowały się prostotą i codziennością, ich celem była formacja praktyczna, duchowna i społeczna uczniów. Figura osoby dorosłej była stworzona przez wychowawczynię. Musiała posiadać ona nie tylko cechy behawioralne każdej matki, tak by móc zabezpieczyć ciągłość rodziny, ale również specjalne umiejętności inicjatywy, organizacji w połączniu z wrażliwością i elastycznością tak, aby jak najlepiej koordynować pracę i życie dzieci. Środowisko i otoczenie musiały odtworzyć klimat rodzinny, do którego dziecko było przyzwyczajone. Szkoła organizowała się w taki sposób, aby jak najbardziej przypominać dom. Była wyposażona, oprócz sali i ogródka ze zwierzętami i roślinami, w pomieszczenie do przechowywania odzieży i „rupieciarnię”, czyli muzeum dydaktyczne.

Według Agazzi, dziecko musiało być zachęcane do działania. Pedagog natomiast miał za zadanie ograniczać lekcje do minimum, pozostawiając jak najwięcej miejsca na swobodną i indywidualną aktywność podopiecznych. Zajęcia, otoczenie i sytuacje były organizowane w taki sposób, aby stymulowały spontaniczność dziecka. Szkoła nie odróżniała zabawy od pracy, ponieważ wszystkie działania dnia codziennego były cenione jako motory edukacyjne o najwyższym znaczeniu i dzięki nim dzieci miały świetną okazję do nauki, odkrywania zasad życia oraz wzajemnego szacunku. Jednym z najbardziej typowych zajęć przedszkolnych było ogrodnictwo, do którego Rosa Agazzi uparcie wracała w swoich tekstach i książkach. Według niej, ogrodnictwo posiada-

\footnotetext{
9 Tamże.
} 
ło wiele celów: przyjemne zajmowanie dzieci w użytecznej pracy i przede wszystkim na świeżym powietrzu. Praca przy grządkach dawała przedszkolakom ogromną satysfakcję. Widziały one narodziny kwiatów i owoców, ale również mogły zrozumieć cykl pór roku w stosunku do naturalnego cyklu uprawiania roślin. Wszystko to kształtowało u nich poczucie własności i odpowiedzialności ${ }^{10}$.

Z kolei Maria Montessori zajmowała się problemami oświaty w kontekście swoich badań naukowych. W roku 1905 zajęła się organizacją przedszkoli w dzielnicy San Lorenzo w Rzymie. Parę lat później otworzyła pierwsze domy dziecka. Montessori na pewno nadała pedagogice naukowe znaczenie. Uważała, że nie można kształcić nikogo, jeśli nic o tym się nie wie. Dzieci mają prawo do nauki i zrozumienia prawdziwych mechanizmów uczenia się i socjalizacji z innymi, która charakteryzuje się odkrywaniem procesów dojrzewania osobowości. Śledząc tę linię, Montessori czerpała swoje inspiracje z metodologii nauczania dwóch francuskich lekarzy: Jeana Marca Itarda i Edouarda Seguina. Obaj opiekowali się dziećmi „dzikimi”, zamieszkującymi odosobnione miejsca. Itard jest prawdopodobnie tym, którego lepiej pamiętamy, chociażby z tego powodu, że wywołał ogromne poruszenie, gdy starał się ponownie wyedukować dzikiego chłopca znalezionego w lesie. Dzięki temu eksperymentowi Montessori zaczęła kierować się zasadą, że „nauka może wszystko”; innymi słowy, że nauka pochodzi ze środowiska zorganizowanego przez człowieka zgodnie z jasnymi kryteriami kulturowymi i pedagogicznymi. Montessori, która studiowała przypadki dzieci opóźnionych w rozwoju, doszła do wniosku, że nagromadzenie różnych deformacji obciąża tym samym późniejszą edukację. Według niej, prawdziwa edukacja jest samokształceniem: pedagogika, metoda, nauczyciel, szkoła - wszystko to jest niezbędnym środkiem pomocniczym do realizacji wewnętrznego „ja”, ale jednocześnie ważnym narzędziem, które ma za zadanie pomóc dziecku w wykorzystywaniu własnych zasobów niezbędnych do wyrażenia samego siebie i odpowiedniego rozwoju. Energia każdego dziecka jest jak rozszalała rzeka, która powoduje hałaśliwe, a czasem kapryśne zachowania. Nauczyciel ma za zadanie stworzyć świat, który pomoże dziecku w procesie harmonijnego i swobodnego rozwoju. Zasługą Montessori było więc naukowe uzasadnienie użyteczności różnych działań z psychologicznego punktu widzenia. W gazetce „Secolo di Milano” (Wiek Mediolanu) lekarka Montessori pisała:

[...] zaopatrzyliśmy szkołę w małe, ładne meble, które kierują działaniami dziecka, tak aby je wszystkie wykorzystać, odstawić na miejsce po tym, jak zostały przeniesione, odbudować po tym, jak zostały zburzone, oczyścić po tym, jak zostały zabrudzone... W rzeczywistości dzieci naprawdę czyściły i naprawdę odkładały na miejsce przedmioty. Robiły to z przyjemnością i dzięki temu zdobywały zdolności, które wydają się być prawie zaskakujące. Jestem pewna, że dla nich jest to prawie objawienie, że do tej pory nie daliśmy im możliwości wykonania ich aktywności w sprytny i inteligentny sposób... oto dlaczego

${ }^{10}$ B. Leone, Il metodo scolastico delle sorelle Agazzi, https://www.studenti.it/metodo sorelle agazzi.html [dostęp: 22.06.2020]. 
$\mathrm{w}$ „Casa dei bambini” [domu dla dzieci] istnieją do ich dyspozycji te wszystkie małe i proste przedmioty, z którymi mogą wykonywać różne rzeczy, aż do samodzielnego nakrywania do stołu czy mycia naczyń. Dzieci znajdują się w centrum szczęśliwego życia ${ }^{11}$.

W historii mamy liczne przykłady na to, jak różnorodne orientacje pedagogiczne mogły się jednoczyć. Było wiele sporów, którym musiały stawić czoła siostry Agazzi, wskazując na wspólne zainteresowanie aspektami życia dzieci w przedszkolach. Z pewnością możemy stwierdzić, że praca pedagogów pokazuje nam, w jaki sposób XIX wiek stał się okresem, w którym po raz pierwszy zaprezentowano pozytywny wizerunek dziecka i jego pełną zależność od procesu uczenia się, którego możliwe rezultaty nigdy wcześniej nie były wyobrażane. Społeczną kwestią czasu była, jak powiedziała Montessori, „dbałość o osobliwości jednostki, jej wolność i doświadczenia, które mogą pomóc mu wzrastać ${ }^{2}$ - to słowa, które godziły najbardziej oświecone umysły, powodując, że ludzie zapominali o niezgodnościach i nieporozumieniach.

\section{Główne aspekty metody}

\section{Dziecko jako bohater w edukacji i w życiu}

Rosa Agazzi była szczególnie wrażliwa na otaczającą ją naturę. Owa wrażliwość zapewne miała wpływ na niektóre jej propozycje edukacyjne, jakimi były: ogrodnictwo, opieka na roślinami czy prace manualne w sali. Wszystko to na pewno nie było łatwym zadaniem. Fakt, że wybitna nauczycielka urodziła się i wychowała w niewielkim mieście na terenie Lombardii, z pewnością stanowił ważny element jej życiorysu, który nie może być pomijany. Same dane biograficzne pani pedagog wydają się niewystarczające, by uwzględnić głęboki szacunek, jaki wyrażała ona do ziemi, rozumianej jako natura, źródło życia oraz miłości. Czuła ona zdumienie na widok panującej w naturze harmonii. Nie trzeba być wyspecjalizowanym ogrodnikiem, nie trzeba książek ani dyplomów, jak pisała Rosa, zwracając się do młodych nauczycielek, wystarczy jedynie wiedzieć, jak przygotować i pielęgnować klomby, aby móc zaspokoić potrzeby roślin, które tam rosną. Wystarczy posiadać ogromne uczucie w stosunku do natury, by być przez nią pochłoniętym i dać przestrzeń temu, co jest nieodłączne w nas, ponieważ od każdego spotkania z nią mogą wyłonić się nowe sugestie wiedzy, które wydzielają podziw, ciekawość i wdzięczność wobec nas samych. Nic więc dziwnego, że młoda pedagog z lekcji Froebla w szczególny sposób doceniła propozycje bezpośredniej relacji dziecka z naturą i całym światem przyrody, możliwości manipulowania różnym

11 M. Grazziani, Sulle fonti del Metodo Pasquali-Agazzi e altre questioni, Istituto di Mompiano Centro Studi Pedagogici Pasquali-Agazzi Comune di Brescia, Brescia 2006, s. 488.

12 E. Moro, Come il metodo Montessori libera i bambini dagli stereotipi di genre, https://thevision.com/cultura/metodo-montessori/ [dostęp: 22.06.2020]. 
materiałami w celu ich obserwacji i zrozumienia zjawisk fizycznych, hodowli roślin i zwierząt oraz zabawy na świeżym powietrzu.

Niewątpliwie kontakt z naturą oraz doświadczenie zdobyte dzięki Pasqualemu, a także pierwsze doświadczenia pedagogiczne w szkołach inspirowane były myślą Froebla. To dzięki niej Agazzi zyskała wiarę, że szacunek do natury stanowi zobowiązanie, którego nie może zabraknąć w edukacji. W rzeczywistości jak najbardziej podzielała ona obawy dyrektora szkół w Bresci, że trwający w tych latach proces uprzemysłowienia i związane z nim wszelkie zjawiska urbanizacyjne powodowały oddalenie się tamtejszej ludności od wartości kultury wiejskiej ${ }^{13}$. Dlatego tak ważna była szkoła. Nie może ona pozostawać obojętna w stosunku do głębokich motywacji socjalnych. Szkoła ma za zadanie, wśród swoich wielu zobowiązań, wzmocnić miłość do wsi, do uczciwego i dostojnego życia, dalekiego od „wulgarności” miast. W ten sposób możemy sobie wytłumaczyć dlaczego w metodzie Agazzi jest tak wiele działań, które dotyczą „ziemi” (ogrodnictwo, hodowla kwiatków, warzyw itp.) i które wymagają użycia narzędzi ogrodniczych. Biorąc pod uwagę jedynie te czynniki, które wyżej wymieniłam, możliwe jest już pełne zrozumienie znaczenia, jakie przyjmuje tego rodzaju edukacja.

Zatrzymajmy się przez chwilę i przeanalizujmy przyczyny, dla których zajęcia poświęcone kultywacji ziemi są najchętniej wykonywane przez dzieci i wokół nich każdego dnia koncentruje się życie przedszkola. Rozważania te będą zasadniczo się odnosić do pewnych działań edukacyjnych promowanych przez obie nauczycielki, i możemy je następująco podsumować:

a) doświadczenia w ogrodzie pozwalają wykształcić u człowieka miłość do ziemi;

b) dziecko, które ma kontakt ze światem przyrody, zyskuje możliwość samodzielnego odkrywania życia;

c) żadne inne środowisko, poza naturalnym, nie pozwala śledzić dziecku ścieżki dobroci, szacunku i hojności ${ }^{14}$.

Rosa Agazzi wielokrotnie zadawała sobie pytanie, jakie znaczenie może mieć ziemia dla dzieci. I stwierdziła ona, że aby móc ukazać jej użyteczność, nie wystarczą tylko słowa, potrzebna jest konkretna praktyka i doświadczenie. W ten sposób dziury, które się kopie w grządkach, spadające liście z drzew dają idealny pretekst do tego, aby zastanowić się nad koniecznością usunięcia ziemi rozproszonej na ścieżce, ponieważ jeśli ona zginie i zostanie jej niewiele na grządkach, możliwości życia roślinek maleją. „Żwir jest potrzebny, ponieważ dzięki niemu nasze stopy są suche, ale ziemia jest cenniejsza, ponieważ daje życie roślinkom” ${ }^{15}$. „Widzicie tę ziemię? - pyta nauczycielka dzieci - gdyby mogła ona mówić, powiedziałaby: proszę pani jestem zmęczona tak bezczynnie leżeć; Bóg stworzył mnie, abym pomogła rosnąć drzewom. Dlaczego nie nauczy pani te dzieci, aby przyniosły jakieś ziarenka i zasadziły je? Aby oczyściły mnie

\footnotetext{
${ }^{13}$ R. Agazzi, Nella cultura pedagogica italiana..., dz. cyt., s. 193.

14 Tamże, s. 195.

15 Tamże, s. 196.
} 
z kamyczków? I aby mnie kochały? Masz rację, ziemio, trzeba pomagać i szanować ciebie" ${ }^{16}$.

Pamiętajmy, że w tamtych czasach nie mówiło się jeszcze o ekologii i ochronie środowiska, ale problem ten został już zauważony przez Rosę. Stawiała ona dziecko w sytuacji, w której miało samodzielnie zdobywać doświadczenia, i to nie tylko w odniesieniu do pojedynczych elementów (ziarno, liść, kwiat itp.), ale w rzeczywistym środowisku naturalnym. Dzięki temu mogło ono zrozumieć całą zależność interakcji rejestrowanych w naturze. Według Agazzi, natura była uważana nie tylko za coś do rozważania, ale za cały świat, w którym dziecko mogło eksperymentować i odkrywać. W szkole Agazzi dzieci były wzywane do przyglądania się rzeczom tzw. inteligentnym okiem (ziemia, którą odkrywa się między kamyczkami, czy liście, które żółkną i spadają z drzew). Przed młodym człowiekiem stawiane były odpowiedzialne zadania, np. opiekować się "gnojownią”, przygotować teren do zasiania i go nadzorować. W ten sposób czuł się on bohaterem doświadczeń, które kształtowały w nim kreatywność, osobistą inicjatywę i dawały okazję do porównania się z innymi.

\section{Materiał dydaktyczny}

Materiał dydaktyczny sióstr Agazzi składał się z przedmiotów i odpowiadających im obrazkom. Zadaniem każdej wychowawczyni, a także dzieci było przyczynić się do przygotowania muzeum dydaktycznego, które wyróżniałoby się bogactwem swoich materiałów. Dawanie dziecku jakiegoś przedmiotu lub obrazka, który musi obserwować, oznacza, że formujemy w nim pewność jego własnej osobowości. W ten sposób może się ono poczuć integralną częścią grupy, a nie tylko zaniedbaną lub bezużyteczną jednostką. Pomoże mu to odnaleźć się w prawdziwym świecie, w rzeczywistości złożonej nie tylko z przedmiotów, ale również faktów i działań. Działania natomiast nie są niczym innym, jak elementami życia i to właśnie szkoła ma za zadanie ustalić relacje przyjaźni między uczniem, przedmiotami i działaniami. Dziecko powinno przyglądać się uważnie, dotykać przedmioty i wreszcie nauczyć się z nich korzystać.

Jeśli chodzi o materiały dydaktyczne, siostry Agazzi wniosły w tej dziedzinie ogromne innowacje w porównaniu z myślami i ideami Froebla. „Dary” tego ostatniego miały być i reprezentować syntezę uniwersalnych i podstawowych zasad i znaków wspólnych wszystkim przedmiotom: ruchowi, bezruchowi, formie. W metodzie Froebla wychowawcy pozbawieni byli artystycznych aspiracji. Zautomatyzowali „dary”, tworząc w ten sposób wszystko sztuczne i nieprawdziwe. Agazzi zaproponowały, aby zmienić trochę drogę i uciekać się bezpośrednio do rzeczywistości bez sztuczności i robić to przez naturalne i spontaniczne procesy, odrzucając w ten sposób symbolikę. Szkoły, zdaniem sióstr, powinny uczyć, zaczynając od praktycznej rzeczywistości. Ich mottem było stwierdzenie, że prawdziwego świata nie nauczymy się z książek i pustych słów, ale z doświadczenia w życiu.

\footnotetext{
16 Tamże, s. 198.
} 
Kwestią do wyjaśnienia jest to, jakie przedmioty powinno się podawać dzieciom. Zgodnie z naturalnymi sposobami edukacji możemy określić zainteresowania dziecka, które są zgodne z jego potrzebami rozwoju. Aby je rozpoznać, wystarczy obserwować dziecko i to, co ono wybiera do zabawy. Przedmioty przez nie wykorzystywane są jego zainteresowaniem, natomiast kieszenie stają się jego prywatnym muzeum. W związku z tym za szybą muzeum dydaktycznego zostały wystawione różnego rodzaju przedmioty znalezione przez dzieci. Mamy tu: pudełeczka, orzeszki, guziki, gwoździki, sznurki, kartki, kamyczki, piłeczki, woreczki czy pojemniki. Zadaniem muzeum było wywołać u dziecka pragnienie wyrażania swoich osądów, dokonując porównań i skojarzeń, ale przede wszystkim siostry Agazzi w miejscu tym widziały świetne pole do ćwiczeń językowych, gdzie dzieci uczyły się nowych nazw znalezionych przedmiotów. Rzeczy wystawione w muzeum były zmieniane i przekładane, tak aby każdy maluch zrozumiał, że wszystko się zmienia i nic tak naprawdę nie jest doskonale, jak by się mogło wydawać na pierwszy rzut oka. Ostatnim i chyba najważniejszym celem muzeum było ukształtowanie u dziecka zwyczaju poszanowania przedmiotów nie tylko własnych, ale i cudzych.

Wątek ten został już zapoczątkowany przez wcześniej poznanego Froebla. Siostry jedynie pokazały go w bardziej ambitnej perspektywie. Według Agazzi, ci którzy uczą się używania danego przedmiotu, muszą również zrozumieć jego wartość i wiedzieć, że wiele rzeczy obecnych w szkole jest kolektywnych i odnoszą się one do wszystkich dzieci, które je dotykają. A zatem z przedmiotów tych mogą korzystać zawsze, bez względu na to, czy ktoś się już nimi wcześniej bawił. Dzieci od najmłodszych lat muszą wiedzieć, że osoba, która nie szanuje rzeczy i je niszczy, odbiera innym radość z ich ponownego użycia. Rosa Agazzi absolutnie nie pochwalała edukacji zezwalającej dzieciom dotykania wszystkiego i kiedy tylko chciały, oraz kategorycznie zakazującej manipulowania przedmiotami. Uważała ona, że w pierwszym przypadku wyrosną oni na młodych wandali, natomiast w drugim - dzieci niezręczne. Koncepcja ta została opisana w książce Rosy Agazzi pod tytułem Come intendo il museo didattico nell'educazione dell'infanzia e della preadolescenza (Jak rozumiem muzeum dydaktyczne w wychowaniu dzieciństwa i wczesnej młodości), gdzie wyraźnie wspomina o tym, w jaki sposób kształcić u dziecka chęć dotykania i poszanowania wszystkiego tego, co mu się podoba. Chcąc poprawić jeden i drugi defekt, należy wyćwiczyć w dziecku codzienne odpowiednie wykorzystywanie przedmiotów. Wspominał o tym już Froebel w metodzie polegającej na ćwiczeniu rączek. To ci, którzy wychowują, mają za zadnie rozszerzać tę inicjatywę, rozwijając relacje nie tylko z materiałem, ale ze wszystkim tym, co może łatwo trafić w ręce małego człowieka.

\section{Rola nauczyciela}

Zrozumiałe jest to, że kiedy Pasquali i siostry Agazzi pracowali razem, musieli sobie radzić z innymi problemami niż nauczyciele teraz. Problemy problemami, ale rola nauczyciela wciąż pozostała ta sama. Rosa Agazzi bardzo często powtarzała młodym 
nauczycielkom, że ich zadanie jest bardzo delikatne, ale i uciążliwe, bardzo często angażujące wszystkie osobiste zasoby, wymagając przy tym fizycznej energii, niezłomnych postaw i silnego charakteru. Rosa wspomniała o tym we wstępie do swojego Przewodnika, gdzie o profesjonalizmie nauczyciela mówi w kategoriach „naszego życia zawodowego"17, bardzo jasno stwierdzając, że nauczanie i kształcenie młodych ludzi to nie tylko kwestia roli, jaką się wykonuje, ale realizacja zadań, dzięki którym dochodzi do samorealizacji.

Jak możemy zauważyć, przygotowanie przyszłych nauczycielek było fundamentalne dla Rosy Agazzi. Konieczne było zatem stworzenie różnego rodzaju kursów, które zapewniłyby im odpowiednią kulturę i wiedzę, zarówno z dziedziny ściśle psychologicznej i pedagogicznej, jak i ze strony znajomości problemów szkoły. Według Agazzi, szkoły, które opierały się wyłącznie na edukacji kulturalnej, a nie na duchownej, nie gwarantowały pełnego przygotowania nauczycieli ${ }^{18}$. Jej zdaniem, nauczycielka powinna być przygotowana do spełniana z powagą, pokorą i wiarą zadań, bez okazywania w obecności dzieci oznak niechęci czy też niezadowolenia z siebie. Rosa Agazzi podzieliła przygotowanie do roli nauczyciela na dwa czynniki.

\section{Przygotowanie kulturalne}

W wielu dziełach Pasqualego i Agazzi można dostrzec ich zainteresowanie odpowiednim przygotowaniem przyszłych nauczycielek. Można by powiedzieć, że był to jeden z najważniejszych motywów ich zaangażowania pedagogicznego i dydaktycznego. Już podczas kongresu pedagogicznego w Turynie w roku 1898 narodziło się wiele kontrowersji i polemik m.in. dotyczących kwestii socjalnych nauczycieli. Od nauczycieli przedszkoli wymagano rozległej ogólnej kultury i wiedzy z dziedzin, takich jak: język włoski, geografia i historia, a także nauki przyrodnicze i gospodarka krajowa. Z drugiej strony ich wykształcenie musiało obejmować przedmioty studiów, takich jak: pedagogika i dydaktyka w połączeniu z prawem i ustawodawstwem przedszkoli, rysunek, śpiew i gimnastyka. Program pedagogiki jako najwyższej dyscypliny miał być skoordynowany z wszystkimi pozostałymi przedmiotami i miał uwolnić przedszkola od nauczania hipotetycznych tradycji, które widziały w nim jedynie instytucję społeczną. Nauczyciele mieli być również dobrze traktowani z punktu widzenia ekonomicznego, mieli mieć zapewnioną możliwość kariery profesjonalnej, by móc dostrzegać pozytywne wartości swojej pracy. Zdaniem Agazzi, godność zawodu i jego smak wynikają z umiejętności uchwycenia problemów i stawiania im czoła w duchu inicjatywy i świadomości, tak aby wiedza i zdolności nabyte podczas przygotowania miały jak najbardziej charakter edukacyjny. W ten sposób przygotowanie i profil zawodowy były ze sobą zintegrowane, gdyż wdrażały one do pedagogicznej znajomości psychologii, kultury i techniki. Każda nauczycielka miała być wykształcona i potrafić

17 R. Agazzi, Guida per le educatrici per l'infanzia, La Scuola, Brescia 1961.

18 F. Altea, Il metodo di Rosa e Carolina Agazzi, Armando Editore, Roma 2011, s. 39. 
przełożyć swoją kulturę na inicjatywę, wrażliwość, odpowiedzialność, chęć eksperymentowania, umiejętność weryfikowania własnych doświadczeń, chęć podnoszenia własnych kwalifikacji oraz edukację innych ludzi ${ }^{19}$.

W epoce, w której bez wątpienia borykano się z konformizmem i radykalizmem, Rosa zaproponowała przygotowanie dla wychowawców, które miało na celu podkreślenie profilu autentycznej i odpowiedzialnej kompetencji edukacyjnej. Był to akt dalekowzroczności, który sprawił, że propozycja Agazzi jest nadal wykorzystywana. Propozycja ta daje nam do zrozumienia, że tylko wtedy, gdy posiadamy wysoki poziom przygotowania profesjonalnego i motywację, możliwe jest stawianie czoła trudnościom. Rosa Agazzi była w stu procentach pewna tego, co mówi i pisze w swoich książkach, gdyż opierała się ona na własnych, osobistych doświadczeniach. W jej dziełach możemy znaleźć również ostrzeżenia, że każdy nauczyciel powinien posiadać własnego przewodnika, który wie, w jaki sposób pobudzać aspiracje do inteligentnej i skutecznej pracy. Sama Agazzi deklarowała, że jej przewodnikiem był prof. Pasquali, który potrafił promować jej idee, poprawiać błędy i otwierać na nowe horyzonty wiedzy.

\section{Przygotowanie profesjonalne}

Aby szkoła była lepsza i spełniała wszystkie zadania edukacyjne i społeczne, konieczne jest, aby przygotowanie nauczycieli coraz bardziej koncentrowało się na wymiarze kulturalnym i profesjonalnym. Instytut Pedagogiczny w Bresci powstał w celu przygotowania nauczycieli przedszkolnych, a także obejmował formacje matek i dziewczynek. Oczywiście, w tej epoce nie było mowy o globalnym systemie edukacyjnym, integracji instytucjonalnej w sposób, w jaki dziś się o tym mówi, ale z całą pewnością wierzono w szkołę jako ośrodek edukacyjny, zdolny do tworzenia odpowiedniego środowiska edukacyjnego z troską o wychowanie. Przygotowanie nauczycieli do pracy nie oznaczało jedynie przygotowania teoretycznego, ale raczej nauczanie, jak żyć swoją pracą poprzez doświadczenie. Doświadczenie profesjonalne zdobyte ramię $\mathrm{w}$ ramię z tymi, którzy osiągnęli już pewien stopień profesjonalizmu, rozumiany jako praktyka i staż. Ten rodzaj ścieżki formacyjnej miał za zadanie połączyć teorię z praktyką, pomagając w przygotowaniu kulturowym i duchowym niezbędnym w edukacji dzieci, a także uczestniczeniu w życiu szkoły. Biblioteka instytutu była miejscem spotkań i przede wszystkim źródłem wiedzy dla przyszłych pedagogów i uczonych. Szkoła dla nauczycielek znacznie różniła się od normalnej szkoły. Przede wszystkim wiele miejsca poświęcała tematyce edukacji dziecka w wieku od 3. do 5. roku życia. Praktyki absolutnie nie były wymijającym momentem kulturowego i teoretycznego wycofania się, ale miały być prawdziwą dyscypliną pedagogiczną. Nauczanie miało na celu uporządkowanie wiedzy z różnych dyscyplin naukowych, a kultura wychowawcy powinna zawsze wywierać wpływ na edukację dziecka. Nauczycielki zostały powoła-

${ }^{19}$ R. Agazzi, Nella cultura pedagogica italiana..., dz. cyt., s. 142. 
ne, aby przygotować warunki do odpowiedniego przyjęcia dzieci, musiały być w stanie zaplanować całą działalność dydaktyczną, unikając sztywnych schematów. Rosa wymagała od wychowawców zaangażowania i dobrej woli. Sugerowała, aby narysować sobie taką „fałszywą” linię całorocznej pracy, ograniczając się jedynie do zasadniczych i najważniejszych linii, tak aby zachować elastyczność i świeżość dydaktyczną ${ }^{20}$. Zauważmy, że wskazówki Agazzi nie straciły na aktualności, jeśli wziąć pod uwagę wysiłki podejmowane w ostatnich dziesięcioleciach przez uczonych, aby zaoferować nauczycielom odpowiednie kompetencje w zakresie elastycznego i jak najbardziej skutecznego modelu dydaktycznego. Pasquali i siostry Agazzi stworzyli profesjonalny profil nauczyciela w przedszkolu.

Dzięki siostrom Agazzi narodził się nowy sposób rozumienia pedagogiki, którą możemy podzielić na:

a) pedagogikę eurocentryczną, która stawia w centrum zainteresowania dziecko, a nie nauczyciela, jak to często ma miejsce w dzisiejszych czasach. Żaden nauczyciel nie może dążyć do przekazywania jakichkolwiek pojęć bez wcześniejszej refleksji nad ich negatywnymi skutkami. Musi on wzbudzać zainteresowania i ożywiać młode umysły;

b) pedagogikę zabawy, która koncentruje się na znaczeniu zabawy jako najbardziej naturalnej formy aktywności każdego dziecka. Zabawa od zawsze miała ogromne znaczenie w edukacji i w dalszym ciągu znajduje się ona na pierwszym miejscu jako jeden z najbardziej skutecznych sposobów uchwycenia u dziecka jego spontaniczności. Przez zabawę dziecka jesteśmy w stanie odwołać się do dokładniejszych i konkretnych badań psychicznych rozwoju jednostki;

c) pedagogikę porządku, która obejmuje wszystkie aspekty życia. Lombardo Radice w swojej książce Il problema dell'educaione infantile (Problem edukacji dziecięcej), opierając się na ideach Agazzi, podaje następujący podział:

- porządek materialny, czyli ten, który dotyczy przedmiotów, z jakimi dzieci mają do czynienia podczas zabaw,

- porządek społeczny, rozumiany jako respekt w stosunku do osobowości innych, ich praw, ich idei i osobistych potrzeb,

- porządek moralny, rządzony przez domenę racjonalną nad wrażliwymi impulsami sumienia ${ }^{21}$;

d) pedagogikę celów, która jest przeciwko wszystkim formalnym zasadom i stereotypom, które reprezentują totalną i kompletną negatywność w sektorze edukacji. Pedagogika przeciwna tworzeniu „chodzących encyklopedii”, a pozytywnie nastawiona na ludzi obdarzonych duchem krytycyzmu.

Dzisiaj już wiemy, jak bardzo ważny jest program kulturalny i profesjonalny. Program taki daje przestrzeń na różne badania, dokumentacje, na praktyki, promowanie

\footnotetext{
20 R. Agazzi, Nella cultura pedagogica italiana..., dz. cyt., s. 147.

21 G.L. Radice, Il problema dell'educazione infantile, 7. edycja, La Nuova Italia, Firenze 1967.
} 
kompetencji nauczycieli, a także pozwala wziąć pod uwagę wartości jako czynniki, które ukierunkowują działania edukacyjne.

\section{Organizacja i działalność szkolna}

Środowisko, w którym się naucza, nie powinno mieć jednego stałego modelu, podobnie jak domy, w których mieszkają dzieci, różnią się między sobą, tak szkoły powinny różnić się jedna od drugiej. Według Agazzi, otoczenie powinno być ozdobne, czyste, wyposażone w meble, które ułatwią dzieciom pracę/życie w ich szkolnej rutynie. $\mathrm{Na}$ zewnątrz, w przypadku braku ogródka szkolnego, wystarczy niewielka przestrzeń, przypominająca trochę dziedziniec, która może być modyfikowana i upiększana dzięki wspólnej pracy dzieci i nauczycieli. W przedszkolu stworzonym przez siostry zajęcia prowadzone były w różnych salach, zarówno wewnątrz, jak i na zewnątrz: pokoje, sala zabaw, refektarz, dziedziniec lub ogródek. Na szczególną uwagę zasługiwała organizacja lokali spełniających zadania sanitarne i higieniczne: szatnia, toaleta, łazienka, czyli miejsca, w których dzieci mogły zrozumieć, że opieka nad własnym ciałem jest jednym z głównych źródeł dobrego samopoczucia i zdrowia. Przedszkole sióstr Agazzi nazywane było „królestwem wody”, gdyż to właśnie w tym miejscu dokonywano obfitych kąpieli. Były to ćwiczenia fizyczne i cywilne, które uświadomić miały kult higieny osobistej, który sprawia, że stajemy się zdrowsi, silniejsi i przede wszystkim wolni od lenistwa i od myśli, że piękno jest jedynie synonimem frywolności. Pojęcie zdrowia stało się wymierne dzięki obecności lekarzy, którzy oferowali swoją opiekę przy użyciu specjalnych narzędzi medycznych, natomiast nauczycielki przyjmowały rolę pielęgniarek. Każde dziecko miało swoją kartę zdrowia, w której rejestrowane były wszystkie kontrole i etapy jego rozwoju fizycznego.

Jeśli zajęcia związane z opieką nad ciałem były jednym z centralnych punktów przygotowania dzieci do życia, to nie mniej ważna była również edukacja językowa. Decydowały o tym dwa aspekty. Pierwszym był język zdobywany podczas zabaw, śpiewów, ćwiczeń praktycznych, pracy manualnej czy rysunku. Działania te wyzwalały różnego rodzaju konwersacje, podczas których nauczycielka, wykonując swoją pracę, słuchała dzieci, poprawiając je, a nawet bawiąc się razem z nimi. Drugim elementem edukacji językowej były ćwiczenia oparte na rzeczach i działaniach. Śpiew był działaniem, które funkcjonowało jako połączenie praktyki języka i estetyki, dzięki któremu dziecko uczyło się zarówno uprzejmości, jaki i sensu piękna. Według Agazzi, każda ekspresja życia, taka jak: zabawa, słowo, śpiew, rysunek, praca, kult natury, modlitwa czy relacja między ludźmi, mogła stać się punktem wyjścia, by przyciągnąć zmysły dzieci do zrozumienia i zasmakowania piękna przez harmonijne funkcjonowanie tych elementów. Oko, które obserwuje, w tym samym czasie uczy się proporcjonować części i w ten sposób tworzy całość, ręka, która z wdziękiem zbliża się do przedmiotów i nadaje im formę poprzez elastyczność ruchów dłoni, i ucho, które potwierdza prawdziwość rytmu melodyczną ciągłością dźwięków ${ }^{22}$. Z pięknych

${ }^{22}$ R. Agazzi, Guida per le educatrici..., dz. cyt., s. 15. 
i dobrych rzeczy rodzi się uczucie, i tym najbardziej pielęgnowanym będzie towarzyskość. Konieczne było zatem stworzenie przez instytut wśród dzieci z różnych klas społecznych odpowiedniej równowagi i atmosfery, która wprowadziłaby do małych umysłów pragnienie życia w porządku, tolerancji, szczerości i szacunku. Komunikatywność można osiągnąć przez wspólne zabawy, ćwiczenia oraz lekcje mające na celu ustanowienie zasad wspólnego pożycia. Od uczuć, które regulują relacje społeczne, przechodzimy do boskości i koncepcji Boga, do której z kolei dzieci zbliżają się dzięki modlitwie i pieśni dziękczynnej za piękne i dobre życie. Przykłady z życia Chrystusa oferowały siostrom niezliczone pomysły edukacyjne: zasada szacunku do każdego stworzenia czy uczucie braterstwa. Zarówno Agazzi, jak i Pasquali widzieli wyraźne różnice między szeroko rozpowszechnionym zwyczajem edukacji dzieci a potrzebami zaproponowanymi przez ich nową metodę. Dlatego przedstawili oni w 31 punktach różnice pomiędzy starym a nowym przedszkolem. Te wyszczególnione poniżej są jedynie kilkoma szczególnie wnikliwymi wyimkami z długiej listy, demonstrującymi wpływ nowej propozycji edukacyjnej i przede wszystkim stanowiącymi kamienie węgielne metody.

\begin{tabular}{|l|l|}
\hline \multicolumn{1}{|c|}{ Stare przedszkole } & \multicolumn{1}{c|}{ Nowe przedszkole } \\
\hline $\begin{array}{l}\text { Celem edukacji jest kształcenie intelektualne } \\
\text { poprzez lekcje }\end{array}$ & $\begin{array}{l}\text { Celem edukacji jest kształcenie intelektualne poprzez } \\
\text { ćwiczenia }\end{array}$ \\
\hline celując do rzeczy i pojęć & celując: dziecko i ideał życia \\
\hline Maksymalny wysiłek: zdobycie nawyków & Maksymalny wysiłek: zdobycie koncepcji \\
\hline Tworzenie świadomości: w słowach & Tworzenie świadomości: w czynach \\
\hline Konwencjonalizm i formalizm & Naturalizm i wolność \\
\hline Mówimy, uczymy się & Robimy, wykonujemy \\
\hline Szkoła obca rodzinie & Szkoła jest rodziną \\
\hline Rzadka gimnastyka & Rzadki siedzący tryb życia \\
\hline Wiedza z książek & Najpierw fakty, potem książki \\
\hline Od reguły do faktu & Od faktu do reguły \\
\hline
\end{tabular}

\section{„Rupieciarnia”, czyli muzeum dydaktyczne}

Rosa Agazzi pewnego dnia odkryła, że jedno z dzieci schowało do kieszeni fartuszka odłamek pozłacanej miski. Kiedy chciała go wyrzucić przez okno, dziecko zaczęło płakać, i ona oddała mu go. W ten sposób narodził się nowy pomysł zbiorów przeróżnych przedmiotów, które dzieci znajdowały na podwórku lub w domu i przechowywały w swoich kieszonkach. Były to: nasiona, rurki, papierki, szkiełka, puszki, odłamki itp. Tak powstało muzeum rupieci, w którym znaleźć można było każdy rodzaj przedmiotów uporządkowanych według formy, wielkości, funkcji czy koloru. Na początku zbiory przechowywane były w niewielkiej szafce. Kiedy przedmiotów zaczęło przybywać, znalazły one swoje miejsce w różnych szufladach w zależności od materiału, z jakiego były zrobione, koloru czy kształtu. Rupiecie te okazały się świetnym 
materiałem dydaktycznym, dzięki któremu dzieci uczyły się form geometrycznych, podobieństw i różnic, a nauczycielki przy ich pomocy prowadziły ćwiczenia motoryczne i językowe. Agazzi uwielbiały wykorzystywać do nauki materiały codziennego użytku, które bez problemów mogły trafić w ręce dzieci. Wolały je bardziej niż przedmioty formalne, wspomniane wyżej w metodzie Froebla ${ }^{23}$. Wykorzystywanie muzeum dydaktycznego było dla sióstr bardzo ważne, gdyż miało za zadanie kształtować nie tylko spontaniczność dziecka, ale również jego umiejętności i koordynację.

Jak pisze Rosa Agazzi w swojej książce Jak rozumiem muzeum dydaktyczne, przedmioty znalezione przez dzieci podzielone były w taki sposób, aby stworzyć cel edukacyjny, a następnie go osiągnąć. Były to:

a) materiały do edukacji sensorycznej, które mogły być przydatne do rozróżnienia kolorów, kształtów czy nawet materiału, z którego są stworzone;

b) materiały do wychowania estetycznego - Agazzi miała na myśli przedmioty, które zachęcają dzieci do poznawania sztuki i pracy;

c) materiały do zabawy;

d) materiały, które można było wykorzystać w praktyce, np. w ogródku ${ }^{24}$.

Jak możemy zauważyć, wykorzystywanie wszystkich tych materiałów w odniesieniu do celów edukacyjnych zgodne jest z zasadami nauczania metody Agazzi. Skutecznie przyczynia się to do rozwoju psychofizycznego malucha i robi to w sposób konkretny i harmonijny. Zaspokojenie potrzeb rozwoju harmonijnego i stopniowego jednostki było dla sióstr jednym z najważniejszych problemów do rozwiązania. Chcąc to uzyskać, należało dać dziecku więcej swobody w jego wyborze materiału i aktywności, które miało zamiar realizować. Przedmioty znalezione przez przypadek, oprócz tego, że wzbudzały zainteresowanie i wyobraźnię u dziecka, to jednocześnie mogły sprawić, że państwo w obliczu dotkliwej sytuacji ekonomicznej i gospodarczej, jaka panowała wówczas we Włoszech, nie musiałoby łożyć pieniędzy na produkcję zabawek.

Zainteresowanie dziecka rodzi się z tego wszystkiego, co wydaje się mu proste, nieskomplikowane. Prostota rzeczy, ich stałe aktualizowanie i odnawianie powodują u dziecka pewien rodzaj gimnastyki umysłowej, który Rosa nazywała „gimnastyką obserwacji”. To nic innego, jak umiejętność obserwowania danego przedmiotu w taki sposób, aby z czasem stał się obiektem zainteresowania dziecka. Oczywiście, nie mówimy tu o zainteresowaniu powierzchniowym, ale o chęci zgłębiania życia tych rzeczy, dlatego Agazzi mówiła o gimnastyce obserwacji.

Pamiętajmy, że materiały wyprodukowane, na których Froebel stworzył całą swoją teorię wychowawczą, dawały poczucie pewnej stabilizacji, ale jednocześnie uniemożliwiały dzieciom pracę nad ich wyobraźnią i rozwijaniem ukrytych umiejętności. W związku z tym Agazzi zrezygnowały z doni (dary), które ograniczały się jedynie do kilku numerów w ich zbiorach, a zdecydowały się na szeroki wybór przedmiotów,

${ }^{23}$ M. Libera, Sorelle Rosa e Carolina Agazzi - dal viaggio nelle scuole italiane tra ' 800 e primi '900, www.atuttascuola.it [dostęp: 3.09.2018].

${ }^{24}$ F. Altea, dz. cyt., s. 93. 
którymi przedszkolaki zwykle się bawią. Różnorodność wszystkiego, co maluch może wziąć do swoich rączek i co może go podekscytować i wzbudzić jego zainteresowanie, prowadzi do większej refleksji, a jednocześnie do poczucia większego zaangażowania i odpowiedzialności w swoim wyborze. W ten sposób młody człowiek uczy się również szacunku do rzeczy, bez względu na to, jaka jest ich wartość.

Koncentrowanie się na doświadczeniach dziecka było silnie odczuwaną przez Rosę Agazzi potrzebą, dlatego utworzyła muzeum dydaktyczne z myślą o stworzeniu na terenie szkoły przestrzeni, w której wszystkie dzieci mogą przynosić własne „przeżycia, zainteresowania i emocje”. Miejsce to - współtworzone przez nauczyciela i jego podopiecznych - pozwalało na budowanie relacji z innymi i uczyło współdziałania z drugim człowiekiem. Rupieciarnię możemy rozumieć jako model środowiska wychowawczego, które pozwala małemu człowiekowi umiejscowić własne doświadczenia w znaczący sposób, organizując je i reorganizując na podstawie pobudzeń pochodzących z tego samego środowiska ${ }^{25}$.

W świetle tych rozważań muzeum dydaktyczne przeniesione do naszych czasów może być realizowane w ramach obecnego przedszkola przez laboratoryjne projekty edukacyjne, w takich samych celach formatywnych, w jakich miało to miejsce w 1921 roku. Według mnie, muzeum dydaktyczne może również znaleźć bardzo ważne zastosowanie na ścieżkach kształcenia samych nauczycieli. Silny związek między intencją edukacyjną a praktyką dydaktyczną podkreśla z jednej strony spójność zachowań wychowawcy, a z drugiej - refleksyjną naturę jego profesjonalizmu. Muzeum to nic innego, jak obserwatorium procesów zdobywania wiedzy u ucznia i potwierdzenie jego zdolności do przekształcania projektu edukacyjnego w nowe działania kształtujące. Rupieciarnia miała i w dalszym ciągu ma za zadanie służyć dzieciom do nauki, a nauczycielom do nauczania.

\section{Nowe potrzeby edukacyjne}

Dzieci, które uczęszczały do giardini d’infanzia (dziecięce ogrody), nie potrafiły i nie musiały umieć czytać; w takim razie, w jaki sposób mogły one samodzielnie rozpoznać rzeczy należące do nich? We wszystkich przedszkolach podopieczni mieli do dyspozycji odzież i drobne narzędzia, którymi musieli umieć zarządzać. W latach, w których nauczały siostry Agazzi, nauczycielki przedmioty te rozdawały dzieciom przypadkowo, bez zwracania uwagi na to, do kogo za każdym razem trafiały, albo przekazywały je każdemu wychowankowi indywidualnie, na podstawie numerka przypisanego do danej osoby lub wypisanego na rzeczach imienia. Pierwszy pomysł był absolutnie do odrzucenia, chociażby dlatego, że brakowało w nim dbałości o higienę. Druga strategia natomiast, nawet jeśli była lepsza od poprzedniej, nie miała żadnego zastosowania wychowawczego i zamieniała małych uczniów w ponumerowane maszyny. Ważne było oczywiście to, aby każda nauczycielka korzystała ze wszystkich

${ }^{25}$ A. Perucca, Esperienze dell'infanzia e prospettive interculturali, vol. IV, Junior, Brescia 2001, s. 73 . 
edukacyjnych i moralnych instrukcji dydaktycznych niezbędnych do zapewnienia jak najbardziej harmonijnego zestawu jej pracy edukacyjnej.

Konieczne było znalezienie nowatorskiego kryterium, które pozwoliłoby maluchom uwolnić się od anonimowości i podziału na poziomy, jaki reprezentowały liczby, których i tak nie potrafiły dekodować. Szkoła absolutnie nie powinna „spłaszczać” dzieci, ale uznawać je za wyjątkowych i niezastąpionych ludzi.

Wyzwanie to podjęły siostry Agazzi, które dały początek idei contrassegni (symbole). Jak już wspomniałam, przedszkola posiadały szafeczki, w których dzieci mogły powiesić swoje rzeczy, ale były one oznaczone numerami. Rosa Agazzi wpadła na pomysł, aby numerki zastąpić symbolami. Oczywiście, symbole i rysunki musiały być dobrane do wieku wychowanków. Dla trzylatków przyporządkowano różne symbole, których nazwy składały się z jednej sylaby (np. kot). Dla dzieci 4-letnich były to przedmioty z życia codziennego, wyrazy trzysylabowe. Na koniec dzieci starsze (5 lat), którym przypisywano figury geometryczne $\mathrm{z}$ wyrazami wielosylabowymi. Zdaniem Agazzi, wykorzystywanie symboli sprawiało, że dzieci przyzwyczajały się do utrzymywania porządku, uczyły się przy tym rozpoznawania własnych rzeczy i przede wszystkim porządkowania własnych idei. Wszystko to pomagało im wzbogacać język.

\section{Symbole}

Symbole to graficzne przedstawienia przedmiotów lub zwierząt, wybranych przez dzieci na początku roku szkolnego. Każdy symbol umieszczany był w dobrze widocznym miejscu na odzieży lub przedmiocie. Takie przyczepianie znaczka dawało dziecku możliwość rozpoznania tego, co do niego należało, wśród innych dostępnych rzeczy. Symbol to nic innego, jak środek, który prowadził ucznia do rozpoznania granic jego własności i własności innych osób. Wyprawka, którą szkoła dostarczała dziecku, była w pełni oznaczona, podobnie jak półki i szuflady mieszczące przedmioty. Symbole pozwalały na przypisanie konkretnego miejsca każdej rzeczy, co ułatwiało dzieciom orientację i możliwość znalezienia przedmiotów, które były potrzebne w danym momencie. Zapewniały one poczucie bezpieczeństwa oraz zapobiegały zgubieniu z powodu niemożności rozeznania wśród wielu innych obiektów.

Jakie obrazki dawać dzieciom? W tym przypadku nauczyciele, nie tylko ci „wczoraj”, ale i ci dzisiejsi, często zbyt mocno skupiają się na wieku biologicznym dziecka, a także na bogactwie nabytych przez niego doświadczeń. Należy zauważyć, że ówczesne przedszkola były podzielone na trzy odrębne sekcje. Do pierwszej zaliczano maluchy trzyletnie, druga to uczniowie w wieku czterech lat i trzecia ostatnia - pięciolatki. Biorąc pod uwagę te grupy, Agazzi zrealizowała system, który wprowadził rozróżnienie symboli różnych sekcji. Nie był to specjalnie przygotowany materiał naukowy, a jedynie przedmioty wspólnego i zbiorowego użytku, z których dzieci uczyły się korzystać w codziennych czynnościach. Następnie były przedmioty osobiste, z których każdy miał swój znak, łatwo rozpoznawalny obraz (przedmioty wspólne dla najmłod- 
szych, kształty geometryczne dla starszych), który stanowił charakterystyczny znak każdego dziecka i wskazywał na jego własność. Ważne było, aby opowiadać dziecku o rzeczach dobrze mu znanych, takich jak: owoce, kwiaty, zwierzęta, drzewa, oczywiście dbając o to, by były one bardzo kolorowe, gdyż cecha ta była i jest szczególnie ceniona przez małe dzieci. Druga grupa posiadała obrazki narzędzi i przedmiotów wykorzystywanych w życiu codziennym. Wychowankowie w tym wieku wzbogacili już swoją wiedzę dzięki przedmiotom napotykanym w szkole oraz rozszerzyły osobiste horyzonty. Trzecia grupa, najstarsza, operowała symbolami przedstawiającymi figury geometryczne. Dzięki oznaczeniom dzieci uczyły się rozpoznawać i szanować zasadę własności, ale nie tylko. Każdy znak miał nazwę, która była powtarzana kilka razy. Słuchając nazwy swojego znaku i znaków koleżanek i kolegów, dziecko wzbogacało swój leksykon, łącząc imię z obrazem. W ten sposób rozpoczynała się edukacja językowa, uzupełniana ożywionym dialogiem z nauczycielem.

Podziału takiego dokonano zgodnie z prawem edukacji, które sięga roku 1922. $\mathrm{Z}$ biegiem lat pojawily się kolejne bardziej zaktualizowane, które odkrywano podczas pracy z dziećmi. Przedszkolaki cechowała zawsze ogromna ciekawość $\mathrm{w}$ stosunku do kolegów, a także ich symboli. Po kilku dniach wspólnego przebywania poznawały one bez problemu własne znaki, a także te należące do rówieśników. Dzięki ich niezwykłej zdolności socjalnej kojarzyły one imię i nazwisko dziecka oraz znak, do którego się odnoszą. W ten sposób dzieci mogły poczuć się jak w środowisku rodzinnym, które doskonale znały i w którym miały własną przestrzeń. Instynkt własności związany był z potrzebami życia fizjologicznego i życia społecznego. Miłość do własnej prywatności była niczym innym, jak przedłużeniem miłości do samego siebie. Pierwsza faza życia noworodka to ta, w której należy do niego wszystko to, co on zjada i trawi, jak mówił Freud. Potem do trzeciego miesiąca życia dziecko uwielbia ssać, w związku z tym uwielbia chwytać, dotykać, naśladować. Podczas tego procesu maluch uświadamia sobie, że może posiadać przedmioty, które trzyma w swoich rączkach, a w fazie bardziej zaawansowanej uważa, że jego rzeczy to te, które znajdują się w jego bezpośrednim zasięgu. Na ostatnim etapie kojarzy na przykład przybory kuchenne z mamą, książki z tatą, a zabawki z samym sobą. Powoli części wszechświata stają się dla niego rozpoznawalne.

Dzięki przedszkolu rodzice i nauczyciele zachęcali dzieci do poczucia własności, dając im możliwość wykonania rzeczy w coraz większych i zróżnicowanych kontekstach. Krok po kroku, żyjąc w jedności z innymi, dziecko przekonywało się o potrzebie poszanowania prawa każdego do posiadania. $\mathrm{W}$ tym przypadku symbole stały się narzędziem, które pomagało w integracji i równowadze społecznej.

Istnieją trzy cele wyznaczone przez symbole i zostały one wyraźnie określone w Guida (Przewodniku) sióstr Agazzi: wychowanie do porządku, wychowanie do uczuć, wychowanie do języka. Jak widać, symbole nie były tylko znakiem rozpoznawczym, ale prawdziwym narzędziem edukacyjnym. 


\section{Wybór personalnego symbolu}

Uczniowie szkół tamtych czasów należeli do różnych klas społecznych: średnia i mała burżuazja, robotnicy, rolnicy. Zamiarem Agazzi było stworzyć codzienną rutynę w taki sposób, aby wszystkie dzieci czuły się na tym samym poziome, $z$ takimi samymi możliwościami, prawami i zobowiązaniami. Wszystko to po to, aby promować równowagę dialogu między dziećmi z różnych środowisk rodzinnych i aby pomóc maluchom w rozwoju niektórych podstawowych wymagań, takich jak: współpraca rówieśnicza i altruizm. Dzieci z trzeciej grupy, zwane także opiekunami, były już na tyle rozwinięte i odpowiedzialne, by zająć się jednym dzieckiem z pierwszego roku. Opiekunowie mieli za zadanie nauczyć swojego podopiecznego, jak dbać o własne ciało i higienę, pielęgnować ogródek i ogólnie podążać za nim w najbardziej dla niego trudnych zajęciach w szkole. Taki sposób pracy miał za zadanie rozwijać poczucie odpowiedzialności wobec drugiego, troszczyć się o niego i z nim współdziałać. Agazzi mówiła o tym w następujący sposób: „Starszy uczeń, zajmując się młodszym, poprawia samego siebie, młodszy podczas gdy pomaga we wzrastaniu swojemu opiekunowi, rozumie dystans między własną niezdolnością a doświadczeniem swojego opiekuna - mistrza. Z tej współpracy rodzą się uczucia, życzliwość i szacunek”26. Te uczucia, razem z braterstwem, były niezmiernie ważne w formacji przyszłej społeczności opartej na harmonii, szacunku i godności ludzkiej.

W wyborze symboli, na początku roku szkolnego, brały udział dzieci z wszystkich trzech grup wiekowych, ale najważniejszą rolę, jak już wyżej wspomniałam, odgrywali wychowankowie z trzeciego roku. Ta prosta ceremonia, w której dzieci wybierały swoje ulubione obrazki, była potrzebna Agazzi jako wskazówka w edukacji do współpracy. Nauczycielka przygotowywała dwa stoliki z wystawą obrazków, które raz wybrane - były odtwarzane na wyprawce każdego ucznia. Na pierwszym stoliku można było znaleźć symbole dla dzieci z pierwszej grupy, a na drugim te dla kolejnych grup. Wychowawczyni prosiła dzieci z trzeciej grupy o to, aby pomogły ich małym podopiecznym w wyborze znaczków. W ten sposób rodziła się animowana rozmowa, dzięki ukierunkowanej interwencji nauczyciela, który brał pod uwagę preferencje każdego ucznia i każdemu z nich pomagał w wyborze: „Ja wiem, że Gino podoba się piłka, przykleimy ją na półce i napiszemy tu na kartce: Gino - piłka. Teresce podoba się ubranko? Tereska - ubranko" ${ }^{27}$. Cała ceremonia trwała do momentu, aż wszystkie dzieci były zadowolone, następnie nauczycielka zwracała się do starszych uczniów: „podejdźcie do półki i weźcie w rączki tę rzecz, która podoba się waszemu podopiecznemu, i pokażcie mu, że potraficie przejść cała salę bez upuszczenia tej rzeczy. Brawo, starsze dzieci nie mają rączek z waty. Zobaczmy? Teraz odłóżcie przedmioty na półkach. Musimy zobaczyć, czy również maluchy potrafią przenieść przedmioty w taki sposób, aby nie wypadły z rąk”28. Starszaki wiedzą, jak powinny być traktowane rze-

\footnotetext{
${ }^{26}$ R. Agazzi, La lingua parlata, La Scuola, Brescia 1973, s. 62.

27 Tamże, s. 54.

${ }^{28}$ Tamże.
} 
czy, natomiast mały uczeń pragnie ich naśladować i właśnie z tego wstępnego założenia rodzi się głęboka więź, która będzie trwała przez cały rok szkolny. Wybór symboli przez dzieci w średnim wieku był trochę inny od tego, jaki miały maluchy. Dziecko wybierało samodzielnie rysunek, opierając się na porównaniu dwóch znaków. Dla tych podopiecznych przyzwyczajonych do spędzania czasu w przedszkolu wychowawczyni mogła wykorzystać inną procedurę. Brała dwa symbole i pytała: „Klara, który z tych dwóch symboli podoba ci się najbardziej?

Klara: Ten.

Wychowawczyni: Wiesz, jak to się nazywa?

Klara: Łyżka.

Wychowawczyni: Łyżka będzie twoim symbolem"29.

W trzeciej sekcji dzieci wybierały bezpośrednio obrazki, które reprezentowały rzeczy i łatwe figury geometryczne. W rzeczywistości starsi wychowankowie mieli do dyspozycji precyzyjne wzory przedmiotów, ponieważ operowali nimi przez lata. Po tym, jak dzieci dokonały wyboru, nauczycielka mogła zorganizować zabawę, w której symbole i rzeczywiste obiekty były porównywane w najdrobniejszych szczegółach dzięki materiałom znajdującym się w rupieciarni. Dzięki takiej lekcji dzieci uczyły się, że oprócz rzeczy w wymiarze fizycznym, którymi można manipulować, istnieją również ich symboliczne reprodukcje. Takie zajęcia miały im pomóc w różnych czynnościach, na przykład kiedy rysowały na kartce papieru obiekt, odtwarzały go sobie w pamięci, w najdrobniejszym szczególe. Stawały się świadome opracowania tego obrazu, który był mniej lub bardziej wierny rzeczywistości. Zgodnie z metodą Agazzi symbole były również niezbędnym narzędziem do edukacji obrazowej.

\section{Wychowanie do porządku}

„Koncepcja porządku musi wejść w życie jako kamień węgielny w każdej rodzinie przedszkolaka" ${ }^{30}$. Powód był bardzo prosty. Do przedszkola w Mompiano przybyły dzieci z ogromnym bagażem wad naturalnych oraz tych nabytych, co czyniło z nich bałaganiarzy i osoby mało zdyscyplinowane. Zadaniem dobrego wychowawcy było przeciwstawienie się takiemu zachowaniu i wprowadzenie stopniowej dyscypliny przez pozwolenie na wolność połączoną z porządkiem i kontrolą. Dziecko umieszczone w przedszkolu musiało poznać zasady i szanować je oraz znaleźć ważne punkty odniesienia, które pozwolą mu uniknąć niepewności i udręki wynikającej z nieporządku i niestabilności. Od momentu narodzin małego człowieka to dorosły narzuca mu rytmy odnoszące się do odżywiania czy odpoczynku w tym chaotycznym świecie, w którym wciąż nie wie, że regularne nawyki są jedynymi punktami odniesienia. Od drugiego roku życia dziecko rozpoczyna okres, w którym zaczyna dotykać i przestawiać przedmioty w takim porządku, jaki jest mu znany i zrozumiały. Mniej więcej w wieku trzech lat zaczyna uczyć się przez powtarzanie manipulacji, że porządek jest

\footnotetext{
29 Tamże.

${ }^{30}$ R. Agazzi, Guida per le educatrici..., dz. cyt., s. 23.
} 
czynnością, którą się wykonuje, ale i usuwa do woli. Z klocków tworzy się wysokie wieże, po czym się je burzy i ponownie zaczyna od zera swoje doświadczenia, kontynuując nowy inny projekt. Symbole tu zatem stawały się ważnym narzędziem, gdyż pomagały one dziecku zorganizować sobie nowe życie w szkole. To, że maluch uporządkowuje sobie wszystko, będzie sprzyjało jego psychicznej równowadze w zorganizowanym społeczeństwie.

Krok po kroku nawyk utrzymywania porządku nabywany był przez dzieci w formie prostych reguł, które były łatwe do zrealizowania, ponieważ symbole nie tylko prowokowały, ale i wspierały inicjatywę. Symbol okazywał się wezwaniem do zobowiązania, by pomóc uczniom w praktyce zrozumieć różnicę między ładem a nieładem.

Jesienią, kiedy otwierano przedszkola, grządki ogródków przedstawiały zaniedbany widok, ponieważ były pozbawione pielęgnacji od lata. $W$ tym przypadku zapraszano dzieci do dokładnego obserwowania stanu degradacji, w którym znajdował się ogródek. Następnie wychowawczyni pokazywała dzieciom grządki, które sama wcześniej uporządkowała. Zadaniem uczniów było przywrócenie porządku reszcie upraw, biorąc pod uwagę przykład nauczycielki. Koncepcja ta powtarzała się za każdym razem, kiedy dzieci przychodziły do szkoły, kuchni, szatni czy sali z zabawkami. Wychowankowie byli pobudzani do tego, by to oni stali się bohaterami działań, które pozwoliły im na przywrócenie porządku w szkole. Pamiętajmy, że w przedszkolu stworzonym przez siostry Agazzi nie był brany pod uwagę porządek narzucany z góry, czyli przez kogoś, ale była to zdolność organizacji przestrzeni, której dziecko stawało się autorem. Działo się tak, ponieważ uczniowie mieli do swojej dyspozycji środki (między innymi symbole), które były niezmiernie ważne w wykonaniu tego zadania.

Niezliczone były okazje, które oferowały nauczycielkom możliwość wpajania tej koncepcji małym ludziom, i zostały one również wyjaśnione w programie edukacji dziecięcej przez założenie, że istnieje porządek estetyczny, który dotyczy pozycji rzeczy (w rzędzie, w linii, w symetrii itp.), porządek osobisty, który odzwierciedlał ideę czystości, oraz porządek ruchu, dokonywany za pomocą prostych ćwiczeń i rytmu. Można by kontynuować z porządkiem praktycznym w przygotowaniu stołówki i w aranżacji mebli w sali czy przedmiotów w szafie. We wszystkim, co robimy, możemy osiągnąć świetne rezultaty, jeśli weźmiemy pod uwagę porządek, według jakiego pracujemy: w przygotowaniu kawy, w ubieraniu się czy podczas jedzenia. Wszystkie te czynności, które powinny być kamieniem węgielnym edukacji, mogą jedynie doprowadzić do ostatecznego celu, którym jest porządek moralny. Trzeźwość jest porządkiem, którego uczy nas Rosa Agazzi. Nędza, choroba często prowadzą do nieładu, podczas gdy ich przeciwieństwo jest nosicielem spokoju i wygody w każdej rodzinie. Nauczyciel z pewnością nie miał na celu wywołania obsesyjnej manii porządku, ale pragnął rozwijać dobre nawyki ułatwiające życie.

Powinniśmy się cieszyć z dobrych manier zdobywanych przez dzieci, dzięki nim będziemy mieli dorosłych, którzy będą w stanie przedstawić swoje pomysły i postę- 
pować zgodnie z logicznym procesem myślenia, a to pozwoli im żyć w harmonii nie tylko $\mathrm{z}$ innymi, ale i z samym sobą.

\section{Nauka języka włoskiego}

„Symbole mają przede wszystkim na celu odróżnienie naszej własności od własności innych, ale możemy również wykorzystać je jako ćwiczenie języka ojczystego. Każdy symbol ma swoją nazwę, a każda nazwa przypomina nam o istnieniu tej rzeczy. Wiele symboli, jak wiele nazw tworzy kopalnię ćwiczeń, zaczynając od poprawnej ich wymowy" ${ }^{31}$. Intuicja agazziana dotycząca nauczania języka ojczystego w przedszkolu ma niewątpliwie ogromne znaczenie w dzisiejszych czasach. Mamy tutaj szansę odkryć inną wartość edukacyjną tego celu, a mianowicie sposób na naukę języka włoskiego. Dziecko, które przybywa do przedszkola, posiada już jakąś podstawę języka, która wynika z otoczenia społecznego, w którym jest ono zanurzone. W pierwszej grupie dzieci mówią kilka słów, używają niepoprawnych wyrazów i często konieczne jest nauczenie ich ponownie nazw przedmiotów. Na tym etapie studiów rozwoju myśli dziecięcej uważa się, że zarówno przedmiot, którym dziecko manipuluje, jak i akcja, która ma miejsce w tej zabawie są bodźcem o wiele potężniejszym niż długie przemówienia nauczycielki lub też bezpłodna prezentacja rysunków. „Jest nieprawdą to, że kształci się, czyniąc dzieciom długie wywody na temat nowych rzeczy i faktów: czasem kilka słów, gest, ekspresyjny ruch, spojrzenia, są skuteczniejsze, aby zainteresować dziecko" ${ }^{32}$. Każde słowo powiązane jest z jakimś obiektem, a jego użycie pozwala wzbogacić słownictwo. Według Agazzi, języka nie można było nauczyć się tylko przez samo mówienie, ale również przez działanie. Język rodzi się z ruchów, uczuć, myśli i podmiotu w jego relacjach z rzeczami. Nauczanie powinno promować zanurzenie się w doświadczeniu, dlatego musimy sprawić, by dziecko mówiło, i pobudzać je do wejścia w relację z przedmiotami ${ }^{33}$. Zobaczmy, jak i za pomocą jakich środków można pomóc dziecku w wypowiadaniu słowa, nie odciągając go od zabawy. Symbole ze względu na znaczenie, jakie mają w dydaktyce Agazzi, zostały podzielone na trzy grupy.

\section{Pierwsza grupa A}

Reprezentują różne przedmioty miłe dla oka maluchów, a nazwa składa się w dużej mierze $z$ dwóch i trzech sylab. Słowa rozpoczęte przez samogłoskę zostały pominięte. Tutaj mamy pewne symbole, do których się odnosi: luna (księżyc), scarpa (but), casa

${ }^{31}$ R. Agazzi, Come intendo il museo didattico nell'educazione dell'infanzia e della preadolescen$z a$, La Scuola, Brescia 1962, s. 54.

32 R. Agazzi, La lignua parlata, dz. cyt., s. 58.

33 Tamże, s. 11. 
(dom), letto (łóżko), sole (słońce), fiore (kwiat), sedia (krzesło), cappello (kapelusz), farfalla (motyl), borsetta (torebka) $)^{34}$.

\section{Druga grupa B}

Nazwy rzeczy używanych w codziennym życiu w celu ćwiczenia wymowy i użycia krótkich oraz pełnych słów i w niektórych zastosowania odpowiedniej nazwy w liczbie mnogiej: cigliege (czereśnie), lampada (lampa), ruota (koło), bicchieri (szklanki), libro (książka), calza (skarpetka), secchio (wiaderko), cucchiaio (łyżka), bottiglia (butelka), coperchio (przykrywka), pentole (garnki).

\section{Trzecia grupa $\mathrm{C}$}

Tu mamy do czynienia z ćwiczeniami językowymi, które obejmują słowa z apostrofem i przyimki: porta chiusa (drzwi zamknięte), ombrello aperto (otwarty parasol), finestra aperta (okno otwarte), posata (sztućce), bilancia (waga), quadro (obraz), testa di uccello (głowa ptaszka), cancello chiuso (brama zamknięta), cinque punti (pięć punktów) $)^{35}$.

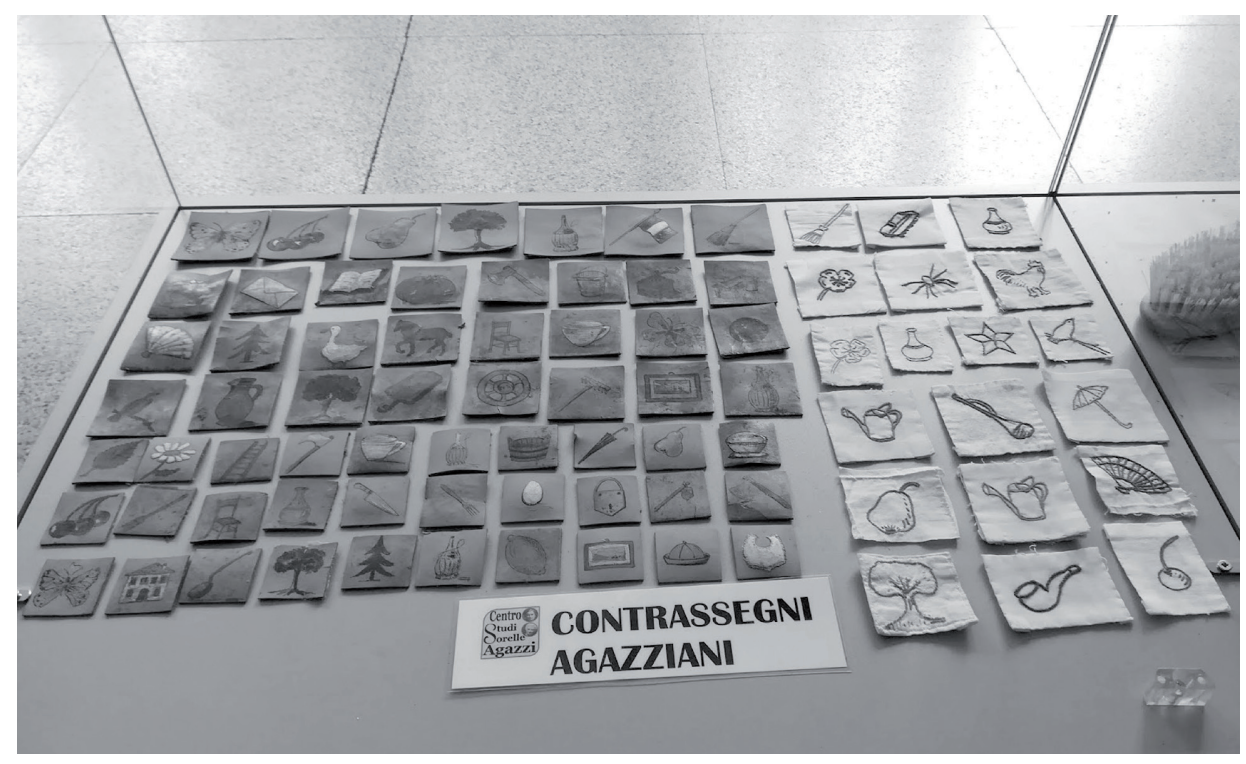

Fot. 1. "Contrassegni Agazziani” - symbole sióstr Agazzi

Źródło: https://centrostudisorelleagazzi.altervista.org/sala1.html [dostęp: 04.2020].

Według sióstr Agazzi, porządek intelektualny można uzyskać jedynie przez oznaczenie poszczególnych przedmiotów, które są własnością dziecka, różnymi symbolami. W ten sposób dzieci odnajdowały własne rzeczy i potrafiły odróżnić je od innych.

\footnotetext{
${ }^{34}$ V. Agostini, M. Chizzolini, La scuola materna italiana, La Scuola, Brescia 1954, s. 76.

35 Tamże, s. 48.
} 
Znaki były bardzo łatwo rozpoznawalne. Dzięki nim przedszkolaki wzbogacały również swoje słownictwo.

Agazzi za wszelką cenę chciały wprowadzić do niedojrzałej duszy dziecka pierwsze odczucia życia, które opierają się na porządku, tolerancji, wzajemnym szacunku i dobrej znajomości języka włoskiego. Rosa Agazzi już pod koniec XIX wieku zdawała sobie sprawę z wagi promocji zdolności językowych dzieci. Jej zdaniem, należy to robić przez zabawę, która oferuje niezliczoną liczbę ćwiczeń niemal zawsze motywowanych działaniem, które ciągle stymuluje do użycia słowa. Agazzi doszła do tej wiedzy nie przez teorię, ale wyłącznie dzięki praktyce. Wykorzystała ona swój bagaż doświadczeń, uważając, że dziecko wchodzi w relacje ze środowiskiem osób i rzeczy, które go otaczają. Podczas zabawy utrwala swoje umiejętności językowe i intelektualne. Bawiąc się, uzyskuje dostęp do świata kultury i tym samym uczy się rozwiązywać wszelkie konflikty.

Śmiało stwierdzam, że elementy metody nauczania stworzone przez siostry Agazzi, a dokładniej symbole, są nieustannie wykorzystywane we włoskich przedszkolach i nadal stanowią doskonałe narzędzie pomagające współczesnym dzieciom odpowiednio się rozwijać. Szczególnie przydatne są proste materiały dydaktyczne, tak bardzo promowane przez Rozę Agazzi. Na pewno umiałaby ona również w XXI wieku zachęcić dzieci do kreatywności: elementu niejednokrotnie zapominanego w zglobalizowanym świecie. O aktualności tej metody nie stanowią jedynie symbole, które z pewnością są jednym z najbardziej atrakcyjnych materiałów dydaktyczny, ale i elastyczność całej koncepcji edukacyjnej, która świetnie przystosowuje się do scholastycznej rzeczywistości tego stulecia.

\section{Bibliografia}

Agazzi R., Alla ricerca di un indirizzo di educazione infantile e un esperimento scolastico, "Pro Infanzia" 1833, n. 5.

Agazzi R., Come intendo il museo didattico nell'educazione dell'infanzia e della preadolescenza, La Scuola, Brescia 1962.

Agazzi R., Guida per le educatrici dell'infanzia, La Scuola, Brescia 1974.

Agazzi R., La lingua parlata, La Scuola, Brescia 1973.

Agazzi R., Nella cultura pedagogica italiana e nella realtà educativa della scuola materna, Pasquali-Agazzi, Brescia 1995.

Agazzi A., Micchietti S.S., Leducazione dell'infanzia nella scuola materna, La Scuola, Brescia 1991.

Agostini V., Chizzolini M., La scuola materna italiana, La Scuola, Brescia 1954.

Altea F., Il metodo di Rosa e Carolina Agazzi, Armando Editore, Roma 2011.

Ariès P., Historia dzieciństwa, przeł. M. Ochab, Wydawnictwo Marabut, Gdańsk 1995. 
Catarsi E., Lasilo e la scuola dell'infanzia, La Nuova Italia, Firenze 1994.

Covato C., Ulivieri S., Itinerari nella storia dell'infanzia, bambine e bambini modelli pedagogici e stili educativi, Edizioni Unicopoli, Milano 2001.

Dabbatucci G., Vidotto V., Storia contemporanea. Lottocento, Laterza, Roma-Bari 2003.

Frabboni F., Pinto Minerva F., La scuola dell'infanzia, Editori Laterza, Bari 2008.

Grazziani M., Sulle fonti del Metodo Pasquali-Agazzi e alter questioni, Istituto di Mompiano Centro Studi pedagogici Pasqauli-Agazzi Comune di Brescia, Brescia 2006.

Honegger Fresco G. (red.), Montessori: perché no? Una pedagogia per la crescita. Che cosa ne éoggi della proposta pedagogica di Maria Montessori nell'Italia e nel Mondo?, Angeli, Milano 2000.

Lanfranchi R., Prellez J.M., Educazione scuola e pedagogia nei solchi della storia, vol. 2, LAS, Roma 2008.

Libera M., Sorelle Rosa e Carolina Agazzi - dal viaggio nelle scuole italiane tra '800 e primi '900, www.atuttascuola.it [dostęp: 3.09.2018].

Macchietti S.S., Alle origini dell'esperienza agazziana: sottolineature e discorsi, Istituto Pasquali-Agazzi, Brescia 2001.

Mazzetti R., Pasquali P., Le Agazzi e la riforma del frobelismo in Italia, Armando, Roma 1967.

Perucca A., Esperienze dell'infanzia e prospettive inteculturali, vol. IV, Junior, Brescia 2001.

Radice G.L., Il problema delleducazione infantile, 7. edycja, La Nuova Italia, Firenze 1967.

Ugonini G., Mompiano, La Scuola, Brescia 1942.

\section{Strony internetowe}

https://occhidibimbo.com/importanza-del-contrassegno-al-nido-infanzia/ [dostęp: 22.06.2020].

https://thevision.com/cultura/metodo-montessori/ [dostęp: 22.06.2020].

https://www.youtube.com/watch?v=hgZ-58JYdLM [dostęp: 01.2019].

https://www.youtube.com/watch?v=Hk6DQKSPJmU [dostęp: 01.2019].

www.studenti.it/Froebel [dostęp: 01.2019].

https://www.studenti.it/metodo sorelle agazzi.html [dostęp: 22.06.2020]. 


\section{The Agazzi Sisters method in preschool education}

Abstract: Italy was not interested in children's education for a very long time. The first childcare centre was founded in 1828 in Cremona by Fr. Ferrante Aporti. In the years 1895-1917, another institution was opened by the Agazzi sisters in Nave, a small province of Brescia. The children they cared for came from a very difficult environment. The founding sisters told young teachers that their job was delicate, often involving all of one's personal resources, requiring physical energy, steadfast attitudes and strong character. According to the Agazzi sisters, a teacher should be prepared to perform her work with humility, without showing signs of resentment in the presence of children. In their work with children, the Agazzi sisters utilized simple and commonly used materials; children could create from scratch and do something independently with their own hands and imagination. Those activities which we colloquially call arts and crafts today had great educational value. They accompanied children in discovering the world, developing the ability to build and to create increasingly consciously. Playing with everything that was natural offered children the opportunity to fully express their creativity. Tidying things and washing hands were also an ideal way to have fun and learn. This is how "Rupieciarnia" ("junk room") was created. This method proved to be a great success and began to expand in many kindergartens in Italy.

Keywords: activity, kindergarten, method, sensory education, aesthetic education, didactic museum, gardening, language learning

About the author: Katarzyna Ewa Kuchnicka is a graduate of the Academy of Humanities and Economics in Lodz in Poland, Faculty of Humanities, Pedagogy. She has an interest in the education of preschool children and a belief in the need for reliable professionalism in this sector. 
Obszar zainteresowań czasopisma naukowego „Kultura i Wychowanie” z założenia ma szeroki zakres. Odwołuje się do zagadnień związanych z interdyscyplinarną relacją kultury i wychowania.

Prezentowane wyniki badań naukowych, głównie z obszaru pedagogiki, ujmowane są w dwa bloki tematyczne rozpraw: filozoficzno-historyczne oraz teoretyczno-empiryczne.

Wersja internetowa, będąca podstawową formą publikacji, dostępna pozostaje na stronie: www.pedagogika.pl

Zespół redakcyjny 